\title{
Article
}

Mycosphere

Doi 10.5943/mycosphere/10/1/22

\section{Mycosphere notes 275-324: A morpho-taxonomic revision and typification of obscure Dothideomycetes genera (incertae sedis)}

\author{
Pem $\mathrm{D}^{1,2}$, Jeewon $\mathrm{R}^{3}$, Bhat $\mathrm{DJ}^{4,5}$, Doilom $\mathrm{M}^{6,7}$, Boonmee $\mathrm{S}^{1,2}$, Hongsanan $\mathrm{S}^{2,9}$, \\ Promputtha $\mathrm{I}^{8,10}$, Xu JC ${ }^{6,7}$, Hyde $\mathrm{KD}^{1,2,8}$
}

${ }^{1}$ School of Science, Mae Fah Luang University, Chiang Rai 57100, Thailand

${ }^{2}$ Center of Excellence in Fungal Research, Mae Fah Luang University, Chiang Rai 57100, Thailand

${ }^{3}$ Department of Health Sciences, Faculty of Science, University of Mauritius, Reduit, Mauritius

${ }^{4}$ Formerly, Department of Botany, Goa University, Goa, India

${ }^{5}$ No. 128/1-J, Azad Housing Society, Curca, Goa Velha-403108, India

${ }^{6}$ Center for Mountain Futures, Kunming Institute of Botany, Chinese Academy of Sciences, Kunming 650201, Yunnan, PR China

${ }^{7}$ World Agroforestry (ICRAF), East and South Asia, Kunming 650201, Yunnan, PR China

${ }^{8}$ Department of Biology, Faculty of Science, Chiang Mai University, Chiang Mai 50200, Thailand

${ }^{9}$ Shenzhen Key Laboratory of Microbial Genetic Engineering, College of Life Sciences and Oceanography, Shenzhen University, Shenzhen 518060, China

${ }^{10}$ Center of Excellence in Bioresources for Agriculture, Industry and Medicine, Department of Biology, Faculty of Science, Chiang Mai University, Thailand

Pem D, Jeewon R, Bhat DJ, Doilom M, Boonmee S, Hongsanan S, Promputtha I, Xu JC, Hyde KD 2019 - Mycosphere Notes 275-324: A morphotaxonomic revision and typification of obscure Dothideomycetes genera (incertae sedis). Mycosphere 10(1), 1115-1246, Doi 10.5943/mycosphere/10/1/22

\begin{abstract}
This is the 6th in a series, Mycosphere notes, wherein 50 taxonomic notes are provided based on types of genera and specimens in the class Dothideomycetes. These genera have so far not been formally accommodated at any lower taxonomic rank and therefore referred to the Dothideomycetes genera incertae sedis. Notes on the economic significance, wherever known, of each genus are also provided, wherever known. Three new families, viz. Dubujianaceae, Endosporiaceae and Macrovalsariaceae, are introduced in this paper. Thirteen genera namely Acarella Syd., Asteronia (Sacc.) P. Henn., Belizeana Kohlm. \& Volkm., Bonaria Bat., Byssocallis Syd., Byssolophis Clem., Dothichiza Lib. ex Roum., Dothidasteromella Höhn., Englerodothis Theiss. \& Syd., Eumela Syd., Gibbago E.G. Simmon, Gibberidea Fuckel and Koordersiella Höhn are assigned to other families based on morphological investigation and phylogenetic analysis of sequence data available in GenBank. Acarella costaricensis Syd. and Perizomella inquinans Syd. are synonymized based on morphology and transferred to the family Vizellaceae. Chaetosticta perforata (Ellis \& Everh.) Petr. \& Syd. (三 Chaetomella perforata Ellis \& Everh.) and Pyrenochaeta erysiphoides Sacc. are synonymized, as all the three species share similar morphological characters and all were collected from the same host (Cirsium sp). The genus Kullhemia P. Karst. is synonymized under Strangospora Körb. based on morphology. The genus Didymocyrtidium Vain. is typified with Didymocyrtidium nudum Vain. (H6022676) as type species. Four genera namely
\end{abstract}


Bahusutrabeeja Subram. \& Bhat, Botryohypoxylon Samuels \& J.D. Rogers, Dilophospora Desm. and Hassea Zahlbr. are excluded from the Dothideomycetes. All taxa are described and illustrated.

Key words - Antennulariellaceae - Botryosphaeriaceae - Dothidotthiaceae - Dubujianaceae Lophiostomataceae - Lophiotremataceae - Morphology - Microtheliopsidaceae Naetrocymbaceae - Perisporiopsidaceae - Phylogeny - Sporocadaceae - Species - Taxonomy Trematosphaeriaceae - Macrovalsariaceae

Table of Contents

The following list of taxa is a continuation from the fifth paper in the series Mycosphere notes (Doilom et al. 2018, 225-274).

Dothideomycetes sensu O.E. Erikss \& Winka

Asterinales M.E. Barr ex D. Hawksw. \& O.E. Erikss. (= Asterotexales Firmino et al.)

Asterinaceae Hansf.

275. Dothidasteromella sepulta (Berk. \& M.A. Curtis) Höhn., Sber. Akad. Wiss. Wien, Math.-naturw. Kl., Abt. 1 119: 421 (1910)

Botryosphaeriales C.L. Schoch, Crous \& Shoemaker

276. Gibberidea visci Fuckel, Jb. nassau. Ver. Naturk. 23-24: 168 (1870) [1869-70]

Capnodiales Woron.

Antennulariellaceae Woron

277. $\quad$ Eumela chiococcae Syd., Annls mycol. 23(3/6): 335 (1925)

Dothideales Lindau

Dothideales, genus incertae sedis

278. Botryochora nigra (Torrend) Torrend, Brotéria, sér. bot. 12(1): 65 (1914)

Pleosporales Luttr. ex M.E. Barr

Dothidotthiaceae Crous \& A.J.L. Phillips

279. Belizeana tuberculata Kohlm. \& Volkm.-Kohlm., Bot. Mar. 30(3): 196 (1987)

Lophiotremataceae K. Hiray. \& Kaz. Tanaka

280. Koordersiella javanica Höhn., Sber. Akad. Wiss. Wien, Math.-naturw. Kl., Abt. 1 118: 833 (1909)

Massarinaceae Munk

281. Byssothecium circinans Fuckel, Bot. Ztg. 19(no. 35): 251 (1861)

Pleosporaceae Nitschke

282. Gibbago trianthemae E.G. Simmons, Mycotaxon 27: 108 (1986)

Tetraplosphaeriaceae Kaz. Tanaka \& K. Hiray.

283. Byssolophis sphaerioides (Nyl. ex P. Karst.) E. Müll., in Müller \& von Arx, Beitr. Kryptfl. Schweiz 11(no. 2): 341 (1962)

Pleosporales, genus incertae sedis

284. Homostegia adusta Fuckel, Jb. nassau. Ver. Naturk. 23-24: 223 (1870) [1869-70] 
Dothideomycetes, families incertae sedis

Coccoideaceae Henn. ex Sacc. \& D. Sacc.

285. Englerodothis kilimandscharica (Henn.) Theiss. \& Syd., Annls mycol. 13(3/4): 285 (1915)

Dubujianaceae D. Pem, Doilom \& K.D. Hyde, fam. nov.

286. Dubujiana glandulifera D.R. Reynolds \& G.S. Gilbert 2005

Endosporiaceae D. Pem, Doilom \& K.D. Hyde, fam. nov.

287. Endosporium populi-tremuloides Tsuneda, in Tsuneda, Davey, Hambleton \& Currah, Botany 86(9): 1023 (2008)

Macrovalsariaceae D. Pem, Doilom \& K.D Hyde, fam. nov.

288. Macrovalsaria leonensis (Deighton) Petr., Sydowia 15(1-6): 298 (1962) [1961]

Naetrocymbaceae Höhn.

289. Bonaria lithocarpi (V.A.M. Mill. \& Bonar) Bat., Publicações Inst. Micol. Recife 56: 439 (1959)

Perisporiopsidaceae E. Müll. \& Arx

290. Asteronia sweetiae Henn., Hedwigia 34: 104 (1895)

291. Byssocallis phoebes Syd., Annls mycol. 25(1/2): 14 (1927)

Vizellaceae H.J. Swart

292. $\quad$ Acarella costaricensis Syd., Annls mycol. 25(1/2): 123 (1927)

Dothideomycetes, genera incertae sedis

293. Achorella ametableta (Rehm) Theiss. \& Syd. Annls mycol. 13(3/4): 340 (1915)

294. Alascospora evergladensis Raja, Violi \& Shearer, Mycologia 102(1): 33 (2010)

295. Anguillosporella vermiformis (Davis) U. Braun, Monogr. Cercosporella, Ramularia Allied Genera (Phytopath. Hyphom.) 1: 233 (1995)

296. Asterinema caseariae Bat. \& Gayão, Anais IV Congr. Soc. bot. Brasil: 160 (1953)

297. Asteromassaria macrospora (Desm.) Höhn., Sber. Akad. Wiss. Wien, Math.naturw. Kl., Abt. 1 126(4-5): 368 (1917)

298. Asteromella ovata Pass. \& Thüm., in Thümen, Mycoth. Univ., cent. 17: no. 1689 (1880)

299. Bactrodesmium abruptum (Berk. \& Broome) E.W. Mason \& S. Hughes, in Hughes, Can. J. Bot. 36: 738 (1958)

300. Botryostroma inaequale (G. Winter) Höhn. [as 'inaequalis'], Sber. Akad. Wiss. Wien, Math.-naturw. Kl., Abt. 1 120: 425 (1911)

301. Bryorella acrogena Döbbeler, Mitt. bot. StSamml., Münch. 14: 131 (1978)

302. $\quad$ Cerodothis aurea Muthappa, Mycologia 61: 737 (1969)

303. Chaetosticta perforata (Ellis \& Everh.) Petr. \& Syd., Annls mycol. 23(3/6): 270 (1925)

304. Chionomyces meliolicola (Cif.) Deighton \& Piroz., Mycol. Pap. 128: 75 (1972)

305. Chuppia sarcinifera Deighton, in Deighton \& Pirozynski, Mycol. Pap. 101: 32 (1965)

306. Coccodothis sphaeroidea (Cooke) Theiss. \& Syd., Annls mycol. 12(3): 271 (1914)

307. Dermatodothis javanica Racib., in Theissen \& Sydow, Annls mycol. 12(3): 280 (1914)

308. Dianesea palmae (F. Stevens) Inácio \& P.F. Cannon, Fungal Diversity 9: 72 (2002)

309. Didymocyrtidium nudum Vain., Acta Soc. Fauna Flora fenn. 49(no. 2): 229 (1921) 
310. Dothichiza populea Sacc. \& Briard, in Saccardo, Syll. fung. (Abellini) 3: 672 (1884)

311. Dothivalsaria megalospora (Auersw.) Petr., Sydowia 19(1-6): 283 (1966) [1965]

312. Excipulariopsis narsapurensis (Subram.) Spooner \& P.M. Kirk, Trans. Br. mycol. Soc. 78(2): 251 (1982)

313. Gilletiella chusqueae (Pat.) Sacc. \& P. Syd., Syll. fung. (Abellini) 14(2): 691 (1899)

314. Harknessiella purpurea (W. Phillips \& Harkn.) Sacc., Syll. fung. (Abellini) 8: 845 (1889)

315. Hypobryon poeltii (Döbbeler) Döbbeler, Nova Hedwigia 37(1): 12 (1983)

316. Lignosphaeria thailandica Boonmee, Thambug. \& K.D. Hyde, in Thambugala et al., Fungal Diversity: 10.1007/s13225-015-0348-3, [62] (2015)

317. Limaciniopsis rollandiae J.M. Mend., in Stevens, Bulletin of the Bernice P. Bishop Museum, Honolulu, Hawaii 19: 58 (1925)

318. Linopeltis ryukyuensis I. Hino \& Katum., Bull. Faculty of Agriculture, Yamaguchi University 11: 15 (1960)

Ascomycota, family incertae sedis

Strangosporaceae S. Stenroos, Miądl. \& Lutzoni

319. Kullhemia moriformis (Ach.) P. Karst., Meddn Soc. Fauna Flora fenn. 2: 183 (1878)

Sordariomycetes O.E. Erikss. \& Winka

Chaetothyriales, family incertae sedis

320. Bahusutrabeeja dwaya Subram. \& Bhat, Can. J. Bot. 55(16): 2204 (1977)

Xylariales, genus incertae sedis

321. Botryohypoxylon amazonense Samuels \& J.D. Rogers, Mycotaxon 25(2): 633 (1986)

Sporocadaceae Corda

322. Dilophospora alopecuri (Fr.) Fr., Summa veg. Scand., Sectio Post. (Stockholm): 419 (1849)

Sordariomycetes genera incertae sedis

323. Hassea bacillosa (Nyl.) Zahlbr., Beih. Botan. Centralbl., Abt. B 13: 150 (1902)

324. Bahusakala olivaceonigra (Berk. \& Broome) Subram. [as 'olivaceo-nigra'], J. Indian bot. Soc. 37: 63 (1958)

\section{Introduction}

Dothideomycetes is the largest class in the Phylum Ascomycota (Kirk et al. 2008, Hyde et al. 2013,) and is characterized by bitunicate and mostly fissitunicate asci (Barr et al. 1979a, b, Berbee 1996, Kirk et al. 2008, Hyde et al. 2013). Species of Dothideomycetes can be endophytes, epiphytes or pathogens on plants, hyper-parasites on other fungi and saprobic or symbiotic with lichens (Taylor et al. 2001, Schoch et al. 2009, Ariyawansa et al. 2014a, 2015, Lücking et al. 2016, , Wanasinghe et al 2017, Tennakoon et al 2018, Jayasiri et al 2019). In recent years, there have been several studies using phylogenetic analyses that have helped to clarify the taxonomic placement of a large number of genera and species and even aided to establish new families (Lumbsch \& Lindemuth 2000, Kodsueb et al 2006a, b, Nelsen et al. 2009, 2011a, Zhang et al. 2012, Zhang et al 2019). However, many studies concentrated mainly on DNA sequence analyses and little attention has been paid to simultaneous morphological characterization (Schoch et al. 2009, Nelsen et al. 2009, 2011b, Phookamsak et al. 2019, Hyde et al. 2019). Those genera without DNA sequence data have not been looked into despite their economic importance. We are in the 
process of studying genera currently considered as the Dothideomycetes, genera incertae sedis (Ariyawansa et al. 2013, Ariyawansa et al. 2014b, Tian et al. 2014, Thambugala et al. 2014, and Wijayawardene et al. 2014a, Doilom et al. 2018). Wijayawardene et al. (2017) listed the taxonomic placements of 1261 genera as an outline and 239 genera were recorded in Dothideomycetes genera incertae sedis in the recently published 'Outline of Ascomycota: 2017' (Wijayawardene et al. 2018). Our studies involve investigation of types or authentic specimens of the genera that have so far been poorly described and establishment of up-to-date descriptions and graphics or photomicrographs, in an attempt to clarify the taxonomic placement of these fungi at the familial and ordinal levels (Table 1). It is anticipated that these genera will be re-collected and molecular data will be provided to confirm their correct placement in future. The data from this paper will be added to the Dothideomycetes website (Dothideomycetes.org, Pem et al. 2019).

\section{Materials and Methods}

\section{Examination of herbarium material}

The holotype and other specimens were borrowed from the fungal herbarium collections of Bishop Museum (BISH), Cornell Plant Pathology Herbarium (CUP), Kew Royal Botanic Gardens (K \& IMI), Conservatoire et Jardin botaniques de la Ville de Genève (G), Farlow Reference Library and Herbarium of Cryptogamic Botany in Harvard University (FH), Karl-FranzensUniversität Graz (GZU), University of Illinois (ILL), University of North Carolina at Chapel Hill (IMS), University of Michigan (MICH), New York Botanical Garden (NY), New Zealand Fungarium Landcare Research (PDD), Swedish Museum of Natural History (S), Microfungus Collection and Herbarium, University of California (UC), UAMH Centre for Global Microfungal Biodiversity (UMAH) and Umea University (UME). Fungal structures on the host substrate were observed with a stereo microscope (Motic SMZ-168) and morphological features were examined using a Nikon ECLIPSE 80i compound microscope fitted with a Canon 750D digital camera. Ascomata were first rehydrated in $5 \% \mathrm{KOH}$. Sections were cut by hand with a razor blade. Fine forceps were used to remove sectioned ascomata and mount in water. Cotton blue and Melzer's reageant were added to water mounts to observe characters that were not clear. Photomicrographs were processed with Adobe Photoshop CS6 Extended version 10.0 (Adobe Systems, USA). Measurements were made using Tarosoft (R) Image Frame Work. Faces of fungi numbers and Index Fungorum numbers were obtained as detailed in Jayasiri et al. (2015) and Index Fungorum (2019).

\section{Phylogenetic Analyses}

DNA sequences of internal transcribed spacer (ITS), small subunit ribosomal RNA (SSU) large subunit ribosomal RNA (LSU) and Translation Elongator factor alpha (TEF) were obtained from GenBank and following recent publications (Liu et al. 2017). Analysis of a wide taxon sampling encompassing all the families of the class Dothideomycetes was performed. Unrelated or ambiguous taxons were excluded and separate trees for each genus of interest (Asteromassaria, Byssothecium, Bahusakala, Byssolophis, Dothichiza, Endosporium, Gibbago, Gibberidea, Lignosphaeria and Macrovalsaria) were selected and analysed separately. Datasets for each gene (ITS, SSU, LSU, TEF) were aligned separately with MAFFT version 6 (Katoh and Toh 2008) with subsequent manual adjustment in BioEdit 5.0.9 (Hall 1999). The software package jModeltest 2.1.1 was used to select the best-fitting models of nucleotide substitution for each gene. The Bayesian information criterion supported the GTR + G + I model as the best fit for ITS, SSU, LSU, TEF gene regions. Topological congruence of datasets was checked by visual comparison of phylogenetic trees obtained from maximum likelihood-based analysis with RAxML (Stamatakis et al. 2008). The Bayesian inference was conducted under different models for each partition of the matrix as evaluated by MrModeltest 2.2 (Nylander et al. 2004). Six simultaneous Markov chains were run for 100 million generations and every 1000th generation a tree was sampled. MCMC heated chain was set with a "temperature" value of 0.15 . All sampled topologies beneath the asymptote (25\%) were 
discarded as part of a burn-in procedure and the remaining trees were used for computing posterior probabilities in the majority rule consensus tree. Branches with Bayesian posterior probabilities greater than 0.90 above each node are given in the phylogenetic trees. Phylograms were visualized with FigTree v1.4.0 program (Rambaut 2012) and reorganized in Microsoft power point (2007) and Adobe Illustrator CS5 (Version 15.0.0, Adobe, San Jose, CA).

\section{Results}

\section{Taxonomy}

We follow the Outline of Ascomycota: 2009 by Lumbsch and Huhndorf (2010) and the Outline of Ascomycota: 2017 by Wijayawardene et al. (2018) for the arrangement of Ascomycota below.

Asterinales M.E. Barr ex D. Hawksw. \& O.E. Erikss. (= Asterotexales Firmino et al.) Asterinaceae Hansf.

Dothidasteromella Höhn., Sber. Akad. Wiss. Wien, Math.-naturw. Kl., Abt. 1 119: 421 (1910)

Epiphytic on leaf of Cinnamomum japonicum, forming large blackened circular areas 1-2 $\mathrm{mm}$. Superficial hyphae, brown to dark brown, difficult to remove from the surface of host. Sexual morph: Thyriothecia superficial, erumpent from mycelia mass, solitary or gregarious, globose to subglobose, more or less carbonaceous, difficult to remove from the host surface, opening by linear or sometimes Y-shaped at the centre of the thyriothecium. Peridium comprising 2-layers, outer layer dark brown, inner layer hyaline, comprising cells of textura angularis. Hamathecium usually lacking pseudoparaphyses. Asci 8-spored, bitunicate, fissitunicate, oblong or subglobose, lacking a pedicel, apical region of asci usually with a thick opaque ocular chamber. Ascospores overlappingly bi-seriate, hyaline, ellipsoidal to fusoid, 1-septate, deeply constricted at the septum, upper cell broader and shorter than lower cell, verrucose. Asexual morph: Undetermined.

Type species - Dothidasteromella sepulta (Berk. \& M.A. Curtis) Höhn. 1910

Notes - Dothidasteromella was introduced by Höhnel (1910) to accommodate Dothidasteromella sepulta as the type species. The genus is characterized by brown to dark brown superficial hyphae forming blackened circular areas, superficial carbonaceous thyriothecia, a peridium of textura angularis, oblong or subglobose 8-spored asci and hyaline to brown, 1-septate, ellipsoidal to fusoid ascospores. The genus Dothidasteromella was placed in the family Asterinaceae based on presence of subcuticular hypostromata and superficial hyphae without appressoria by Von Arx and Müller (1975). There are currently 13 epithets under the genus Dothidasteromella. Hongsanan et al. (2014) studied the isotype and holotype specimen and placed the genus in Dothideomycetes genera incertae sedis as the characters of the asci and ascospores were not clear. In this study, we re-observed the holotype specimen (F56756). Based on the morphological re-examination of the specimen, it is characterized by Y-shaped thyriothecia, 8spored oblong to subglobose asci, lacking a pedicel and 1-septate brown ascospores which are typical of the genus Asterina, accommodated in Asterinaceae. We therefore, place the genus Dothidasteromella in Asterinaceae until molecular data becomes available for further confirmation.

Dothidasteromella sepulta (Berk. \& M.A. Curtis) Höhn., Sber. Akad. Wiss. Wien, Math.-naturw. Kl., Abt. 1 119: 421 (1910)

$\equiv$ Asterina sepulta Berk. \& M.A. Curtis, Proc. Amer. Acad. Arts \& Sci. 4: 129 (1860) Index Fungorum number: IF 195171; Facesoffungi number: FoF 06236

Epiphytic on leaf of Cinnamomum japonicum, forming large, blackened, 1-2 mm, circular areas. Colonies $2-4 \mu \mathrm{m}$ diam., $(\bar{x}=3 \mu \mathrm{m}, \mathrm{n}=10)$, brown to dark brown, difficult to remove from the surface of host. Sexual morph: Thyriothecia 624-882 high $\mu \mathrm{m} \times 493-1836$ diam. $(\bar{x}=1061 \times$ $706 \mu \mathrm{m}, \mathrm{n}=6$ ), superficial, erumpent from mycelia mass, solitary or gregarious, globose to subglobose, more or less carbonaceous, difficult to remove from the host surface, opening by linear or sometimes Y-shaped at the centre of thyriothecium. Peridium 7-11.5 $\mu \mathrm{m}$ diam., comprising 2- 


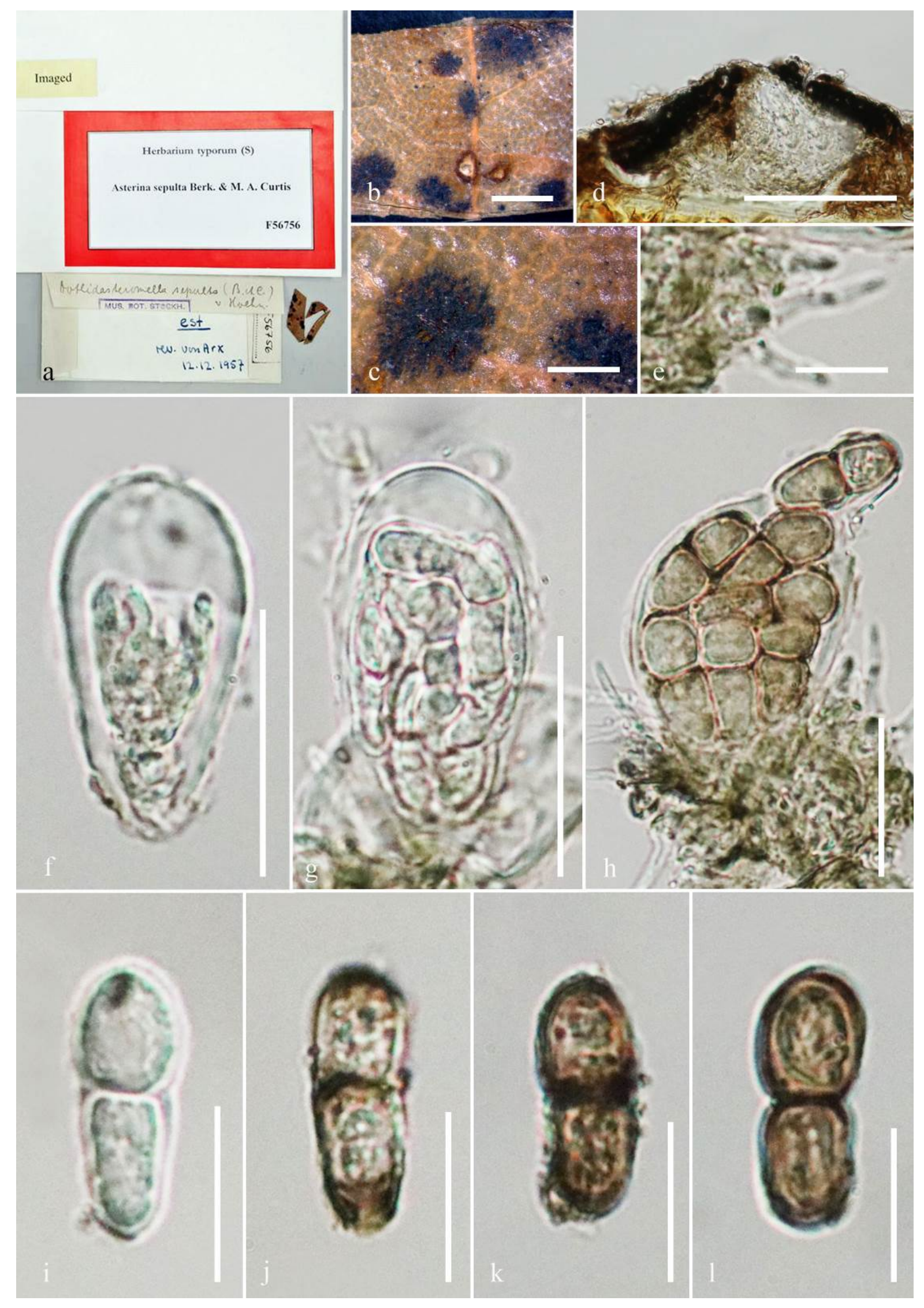

Figure 1 - Dothidasteromella sepulta (S-F56756, holotype). a Details of herbarium material. b, c Habit and appearance of ascomata on host surface. d Section of ascoma. e Hamathecium. f-h Asci. i-l Ascospores. Scale bars: $b=2 \mathrm{~mm}, \mathrm{c}=1 \mathrm{~mm}, \mathrm{~d}=50 \mu \mathrm{m}, \mathrm{e}, \mathrm{i}-\mathrm{l}=10 \mu \mathrm{m}, \mathrm{f}-\mathrm{h}=20 \mu \mathrm{m}$. 
layers, outer layer dark brown, inner layer hyaline, comprising cells of textura angularis. Hamathecium lacking pseudoparaphyses. Asci 27-34 $\mu \mathrm{m} \times 13-23 \mu \mathrm{m}(\bar{x}=30.5 \times 17.8 \mu \mathrm{m}, \mathrm{n}=$ 10), 8-spored, bitunicate, fissitunicate, oblong or subglobose lacking a pedicel, apical region of asci usually with a thick opaque region and ocular chamber. Ascospores $15-16 \mu \mathrm{m} \times 4-5 \mu \mathrm{m}(\bar{x}=16 \times$ $5 \mu \mathrm{m}, \mathrm{n}=10$ ), overlapping bi-seriate, hyaline when immature, pale brown to dark brown at maturity, ellipsoidal to fusoid, 1-septate, strongly constricted at the septum, upper cell broader and shorter than lower cell, verrucose. Asexual morph: Undetermined.

Material examined - JAPAN, on the leaf of Cinnamomum japonicum (Lauraceae), November 1867, C. Wright (S-F56756, holotype).

Economic significance - Species of Dothidasteromella appear to be members of sooty moulds and they coat fruits and leaves cursorily with black mycelia, which decreases photosynthesis rates of host plants (Chomnunti et al. 2014).

\section{Botryosphaeriales C.L. Schoch, Crous \& Shoemaker \\ Botryosphaeriaceae Theiss. \& Syd. 1918 \\ Gibberidea Fuckel, Jb. nassau. Ver. Naturk. 23-24: 168 (1870) [1869-70]}

= Sphaeropsis Sacc., Michelia 2(no. 6): 105 (1880)

Saprobic or pathogenic on stem. Sexual morph: See Phillips et al. (2013). Asexual morph: Conidiomata immersed to semi-immersed, unilocular, subglobose. Peridium composed of dark brown cells of textura angularis. Paraphyses hyaline, aseptate, up to $50 \mu \mathrm{m}$ long and $2 \mu \mathrm{m}$ wide, with a bulbous tip $5 \mu \mathrm{m}$ diam. Conidiogenous cells enteroblastic, hyaline, discrete proliferating internally to form periclinal thickenings. Conidia oval, apex obtuse to rounded, base obtuse or truncate, moderately thick-walled, initially hyaline, becoming brown, externally smooth-walled, internally finely verruculose-walled.

Type species - Gibberidea visci Fuckel

Notes - The genus Gibberidea was introduced as a monotypic genus by Fuckel (1870). The genus Gibberidea is given as a synonym of Botryosphaeria Ces. \& De Not. in Index Fungorum (2019). Wijayawardene et al. (2017) placed Gibberidea in Dothideomycetes, genera incertae sedis. We could not examine the type material, but studied a specimen of Gibberidea visci from ILL herbarium. Based on morphology, it seems that the genus Gibberidea is a synonym of Sphaeropsis (Phillips et al. 2008, 2013). Phillips et al. (2013) considered Phaeobotryosphaeria as a synonym of Sphaeropsis and the older name Sphaeropsis is used based on the one fungus-one name concept. The genus Gibberidea is characterized by immersed to semi-immersed conidiomata and hyaline to brown ascospores. It seems clear that the genus Gibberidea should be placed in Botryosphaeriaceae and is a synonym of Sphaeropsis. In our analyses (Fig. 2), the strains Phaeobotryosphaeria visci CBS 186.97 and CBS 100163 cluster in Botryosphaeriaceae. We therefore, agree with Phillips et al. (2008) and exclude Gibberidea from Dothideomycetes genera incertae sedis.

Gibberidea visci Fuckel, Jb. nassau. Ver. Naturk. 23-24: 168 (1870) [1869-70]

Fig. 3

Current name: Phaeobotryosphaeria visci (Kalchbr.) A.J.L. Phillips \& Crous, in Phillips, Alves, Pennycook, Johnston, Ramaley, Akulov \& Crous, Persoonia 21: 47 (2008)

Index Fungorum number: IF 227688; Facesoffungi number: FoF 06243

Saprobic or pathogenic on undetermined plant stem. Sexual morph: See Phillips et al. (2013). Asexual morph: Conidiomata 290-397 $\mu \mathrm{m}$ high $\times 422-454 \mu \mathrm{m}$ diam. $(\bar{x}=327.3 \times 444.8 \mu \mathrm{m}, \mathrm{n}=$ 10), immersed to erumpent, unilocular, subglobose. Peridium $33-55 \mu \mathrm{m}$ composed of dark brown cells of textura angularis. Conidiogenous cells $4-13 \mu \mathrm{m} \times 7-14 \mu \mathrm{m}(\bar{x}=8.5 \times 10.8 \mu \mathrm{m}, \mathrm{n}=10)$, hyaline, enteroblastic, discrete, proliferating internally to form periclinal thickenings. Conidia 34 $43 \mu \mathrm{m} \times 14-17 \mu \mathrm{m}(\bar{x}=40.1 \times 16.7 \mu \mathrm{m}, \mathrm{n}=10)$, oval, apex obtuse to rounded, base obtuse or truncate, moderately thick-walled, initially hyaline, becoming brown, externally smooth-walled, internally finely verruculose.

Notes - Phillips et al. (2008) recorded the size of conidiomata of Sphaeropsis visci as 'up to $300 \mu \mathrm{m}$ ', conidiogenous cells as ‘ $(4-)$ 8.5-11× 4-6.5 $\mu \mathrm{m}$ ’ and conidia as ‘ $(27-29-33(-50) \times(14.5-$ 
) 15.5-19(-22) $\mu$ m’ which is similar to our examined specimen.

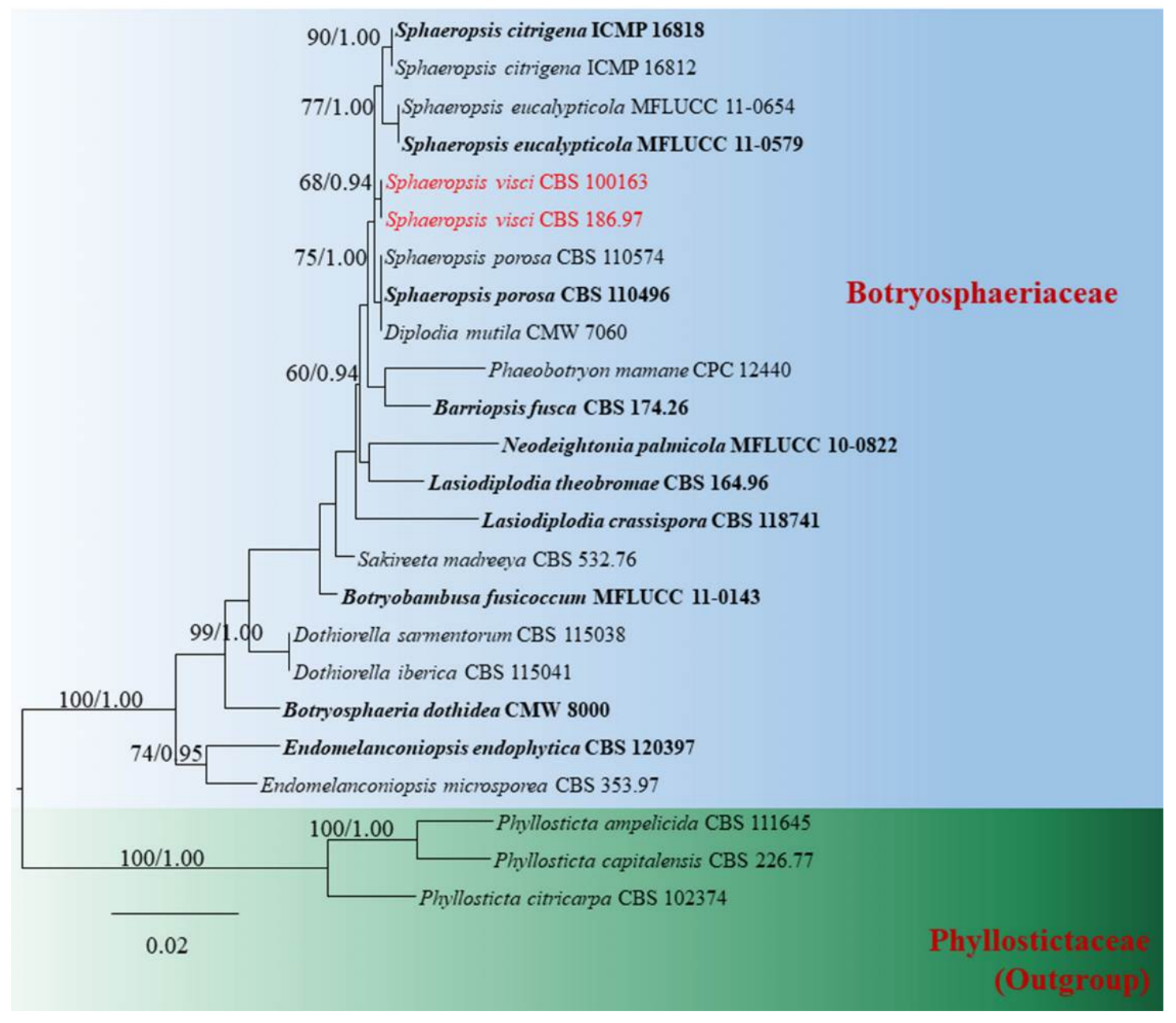

Figure 2 - Phylogram generated from maximum likelihood analysis based on LSU sequence data retrieved from the GenBank. Related sequences were retrieved from Liu et al. (2017). Twenty four taxa are included in the analyses which comprise 965 characters after alignment. Phyllosticta ampelicida, Phyllosticta capitalensis and Phyllosticta citricarpa are used as the out-group taxa. Maximum likelihood (ML) analysis was conducted in the CIPRES Science Gateway V. 3.3. The best sorting RaXML tree with a final likelihood value of -2440.002151 is presented. Estimated base frequencies were as follows: $\mathrm{A}=0.255123, \mathrm{C}=0.215800, \mathrm{G}=0.310407, \mathrm{~T}=0.218670$; substitution rates $\mathrm{AC}=1.413575, \mathrm{AG}=4.032008, \mathrm{AT}=1.495545, \mathrm{CG}=0.857086, \mathrm{CT}=$ $13.775815, \mathrm{GT}=1.000000$; gamma distribution shape parameter $\alpha=0.020000$; proportion of invariant 0.246495 . ML bootstrap values $\geq 50 \%$ are given as the first set of numbers and approximate likelihood-ratio test (aLRT) $\geq 0.90$ values as the second set of numbers above the nodes. Voucher/strain numbers are given after the taxon names, the one from type material are indicated in bold face. Sequence of interest is indicated in red. The bar length indicates the number of nucleotide substitutions per site.

Material examined - GERMANY, Saxony, on submerged decaying leaves, 7 November 1965, J.L. Crane (ILL00088985).

Economic significance - Sphaeropsis visci is a pathogen of Viscum album (mistletoe) (Varga et al. 2012).

Capnodiales Woron.

Antennulariellaceae Woron

Eumela Syd., Annls mycol. 23(3/6): 335 (1925) 
Parasitic on living leaves of Chiococca racemosa, colonies large, superficial, irregular, black, with superficial mycelium forming a network, hypophyllous, dark brown outwardly. Sexual morph: Ascomata sessile, small, superficial, solitary, scattered, globose to subglobose, black, papillate, surrounded by brown to dark brown appendaged, undulate hyphae, branched, septate. Peridium comprising brown cells of textura angularis to subglobosa, lacking pseudoparaphyses. Hairy hyphae longer than $100 \mu \mathrm{m}$, pale brown to dark brown, simple, unbranched, numerous, straight or curved, septate, gradually paler upwards, flexuous, slightly constricted at the septa, apex rounded. Asci 8-spored, bitunicate, broadly clavate, cylindrical to nearly ellipsoidal, sessile, slightly thickened and bluntly rounded near the apex. Ascospores multi-seriate, overlapping, oblong to ovoid oblong, ends rounded, 1-septate, slightly constricted at the septum, hyaline, smooth-walled. Asexual morph: Undetermined.

Type species - Eumela chiococcae Syd.

Notes - The monotypic genus Eumela was introduced by Sydow (1925) for Eumela chiococcae found on living leaves of Chiococca racemosa in Costa Rica. Eumela is closely associated to Episphaerella Petr., Eudimeriolum Speg. and Lasiostemma Theiss. \& Syd., but differs from these genera in having hyphae penetrating the epidermal cells, stromata as well as guard cells forming haustoria. The genus Episphaerella form extensive mycelium all over leaf tissues.

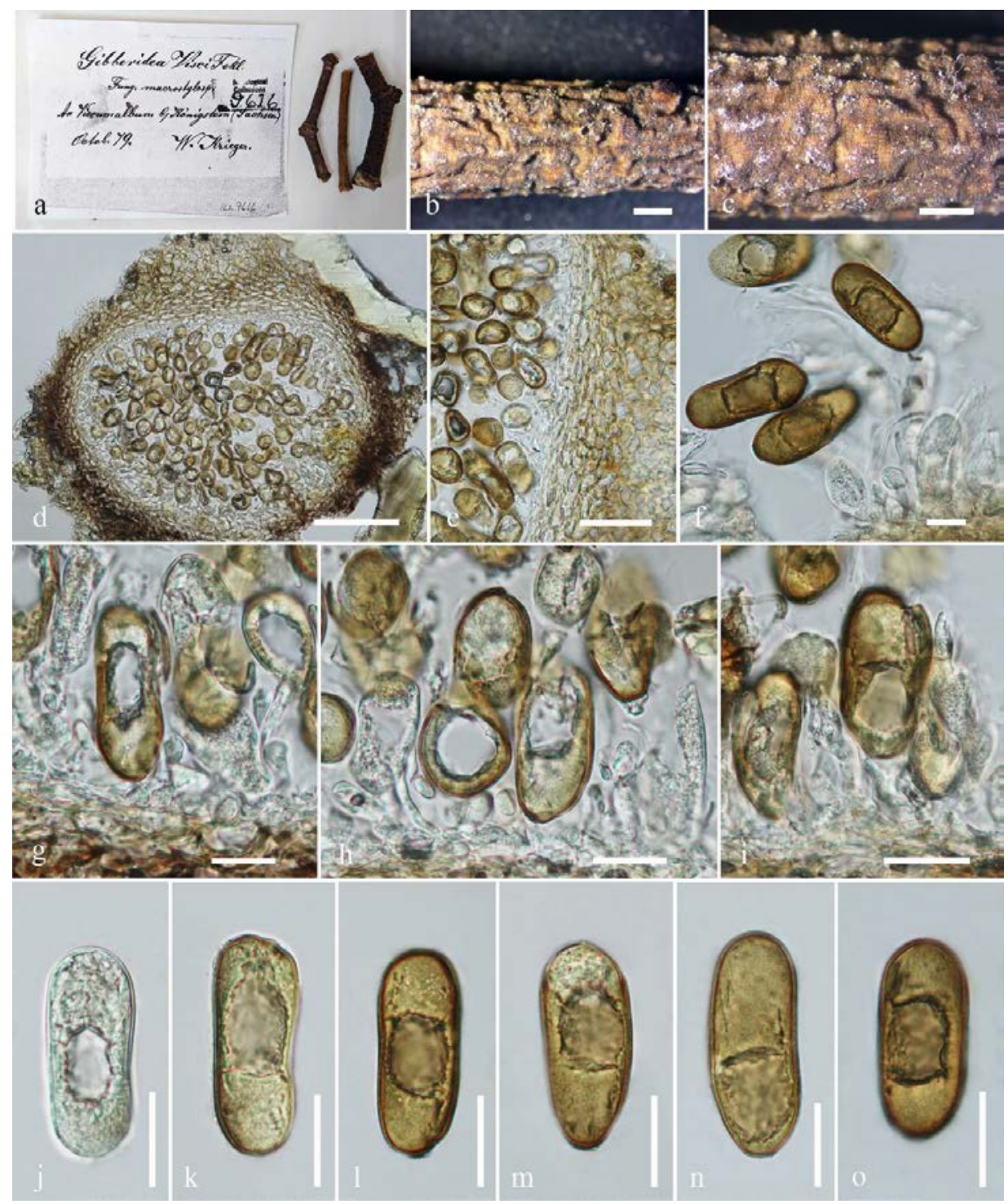

Figure 3 - Gibberidea visci (ILL 00088985) a, b Herbarium material. c Appearance of conidiomata on host surface. d Section of conidioma. e Peridium. $\mathrm{f}-\mathrm{i}$ Conidiogenesis. j-o Conidia. Scale bars: b, $\mathrm{c}=1 \mathrm{~mm}, \mathrm{~d}=100 \mu \mathrm{m}, \mathrm{e}-\mathrm{o}=20 \mu \mathrm{m}$. 
The hyphae of Eudimeriolum are totally superficial or penetrating trichomes. The hyphae of Lasiostemma form a discrete hyphal layer in or under the cuticle (Farr 1984, Barr 1987). The asexual morph is unknown. The genus Eumela was previously placed in Pseudoperisporiaceae (Lumbsch \& Hundorf 2010, Hyde et al. 2013, Kirk et al. 2013). However, Boonmee et al. (2017) treated Eumela as a genus in Dothideomycetes genera incertae sedis. In this study, we examined the syntype of Eumela chiococcae and illustrate the morphological characters. It seems that species of Eumela resemble those of Antennulariella, by superficial subglobose to globose ascomata with hyphal appendages, aparaphysate hamathecium and clavate to ellipsoidal 8-spored asci. The genus Eumela is therefore transferred to Antennulariellaceae based on the sexual morph characters, numerous aerial mycelium colonies and ascospores features

Eumela chiococcae Syd., Annls mycol. 23(3/6): 335 (1925)

Fig. 4

Index Fungorum number: IF 260515; Facesoffungi number: FoF 06241

Parasitic on living leaves of Chiococca racemosa, colonies large, superficial, irregular, black, with superficial mycelium forming a network, hypophyllous, dark brown outwardly. Sexual morph: Ascomata 50-85 $\mu \mathrm{m}$ high $\times$ 73-75 $\mu \mathrm{m}$ diam, sessile, small, superficial, solitary, scattered, globose to subglobose, black, papillate, surrounded by brown to dark brown, undulate hyphae, longer than $100 \mu \mathrm{m}$, branched, septate. Peridium comprising brown cells of textura angularis to subglobosa, lacking pseudoparaphyses. Hairy peridial hyphae longer than $100 \mu \mathrm{m}$, pale brown to dark brown, simple, unbranched, numerous, straight or curved, septate, gradually paler upwards, flexuous, slightly constricted at the septa, apex rounded. Asci $12-17 \mu \mathrm{m} \times 7-8 \mu \mathrm{m}(\bar{x}=15.7 \times 8.0$ $\mu \mathrm{m}, \mathrm{n}=10)$, 8 -spored, bitunicate, broadly clavate, cylindrical to nearly ellipsoidal, sessile, slightly thickened and bluntly rounded near the apex. Ascospores 10.0-10.5 $\mu \mathrm{m} \times 2.5-3.0 \mu \mathrm{m}(\bar{x}=10.3 \times$ $2.8 \mu \mathrm{m}, \mathrm{n}=10$ ), multi-seriate, overlapping, oblong to ovoid oblong, ends rounded, 1-septate, slightly constricted at the septum, hyaline, smooth-walled. Asexual morph: Undetermined.

Material examined - COSTA RICA, Alajuela, Grecia, on living leaves of Chiococca racemosa L., (Rubiaceae), 19 January 1925, H. Sydow (S-F11419, syntype).

Economic significance - Eumela chiococcae are sooty moulds which form hyphae and colonies on leaf surfaces covering the entire leaves or plants. They are reported as plant disease agents because of their negative effects on photosynthesis. They block sunlight from leaf chloroplasts, thus reducing the plants' energy production (Nelson 2008, Chomnunti et al. 2014, Laemmlen 2011).

\section{Dothideales Lindau}

Dothideales, genus incertae sedis

Botryochora Torrend, Brotéria, sér. bot. 12(1): 65 (1914)

Saprobic on unidentified bark. Sexual morph: Undetermined. Asexual morph: Stromata superficial, scattered, broad, flattened turbinate, multiloculate, often supported by a stalk at the central point, collapsing when dry, with folded margin, black, coriaceous. Conidiomata pycnidial, multiloculate, immersed in stroma, brown to black, coriaceous. Peridium 1-layered, composed of black to brown cells of textura angularis. Conidiophores macronematous, septate, unbranched, smooth, hyaline. Conidiogenous cells enteroblastic, hyaline, funnel-like, integrated. Conidia oblong to ellipsoid, hyaline, aseptate, with granular cytoplasm, smooth-walled.

Type species - Botryochora nigra (Torrend) Torrend

Notes - The monotypic genus Botryochora was introduced by Torrend (1914) based on type species Botryochora nigra Torrend (三 Megalonectria nigra Torrend) which was previously classified in Nectriaceae, Sordariomycetes. Botryochora nigra was found on unidentified bark of trees in Kisanty Congo, Mozambique. This genus was later placed in Dothioraceae by Hawksworth et al. (1995) and Lumbsch and Huhndorf (2010). The genus is characterized by superficial stromata with locules, 8-spored asci and smoky brown ascospores. The asexual morph as observed by Thambugala et al. (2014) is coelomycetous, who transferred the genus to Dothideales, genera incertae sedis based on morphology. We examined another specimen from $\mathrm{S}$, but did not observe 
any sexual morph of Botryochora nigra. Presently, we follow Thambugala et al. (2014) and place Botryochora in Dothideales genera incertae sedis.

Botryochora nigra (Torrend) Torrend, Brotéria, sér. bot. 12(1): 65 (1914)

Fig. 5

$\equiv$ Megalonectria nigra Torrend, Bull. Jard. bot. État Brux. 4: 8 (1914)

Index Fungorum number: IF 293763; Facesoffungi number: FoF 06220

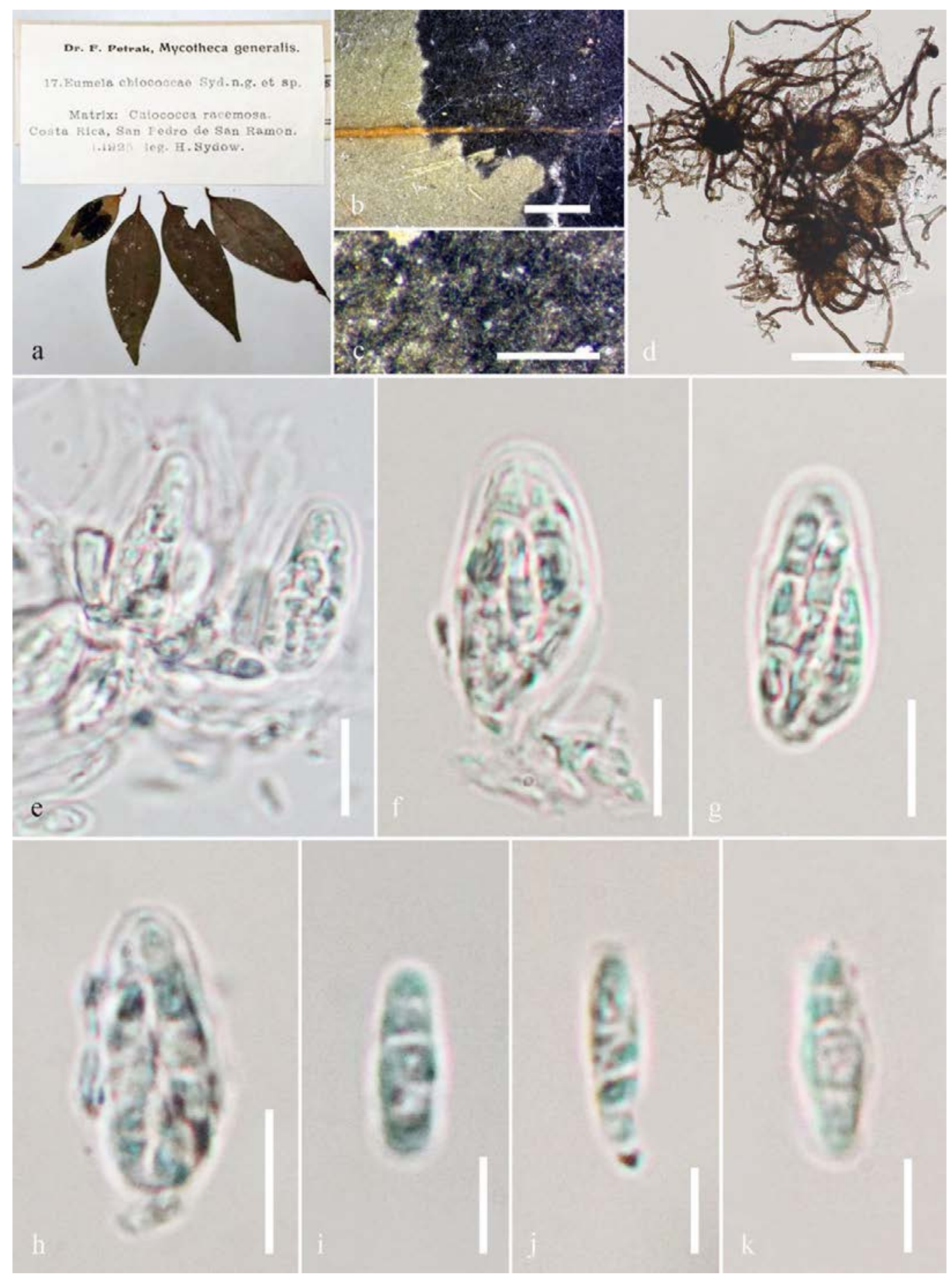

Figure 4 - Eumela chiococcae (S-F11419, syntype). a Details of herbarium material. b, c Habit and appearance of ascomata on host surface. d Squash mount of ascoma, peridium and mycelia. e-h Asci. i-k Ascospores. Scale bars: b, c $=500 \mu \mathrm{m}, \mathrm{d}=100 \mu \mathrm{m}, \mathrm{e}-\mathrm{h}=10 \mu \mathrm{m}, \mathrm{i}-\mathrm{k}=5 \mu \mathrm{m}$.

Saprobic on unidentified bark. Sexual morph: Undetermined. Asexual morph: Stromata 940$964 \mu \mathrm{m}$ high $\times 1558-1675 \mu \mathrm{m}$ diam. $(\bar{x}=1616.8 \times 951.6 \mu \mathrm{m}, \mathrm{n}=5)$, superficial, scattered, broad, 
flattened turbinate, multiloculate with 3-5 locules, often supported by a stalk at the central point, collapsed when dry, with folded margin, black, coriaceous. Conidiomata 98-368 $\mu \mathrm{m}$ high $\times 112$ $363 \mu \mathrm{m}$ wide $(\bar{x}=270.6 \times 272.7 \mu \mathrm{m}, \mathrm{n}=8)$, immersed in stromata, brown to black, coriaceous. Peridium one layer, 3-4 $\mu \mathrm{m}$ wide, composed of black to brown cells of textura angularis. Conidiophores $12-17 \mu \mathrm{m} \times 3-4 \mu \mathrm{m}(\bar{x}=13.4 \times 3.7 \mu \mathrm{m}, \mathrm{n}=20)$, septate, unbranched, hyaline. Conidiogenous cells enteroblastic, hyaline, with funnel-like collarette, integrated. Conidia 36-41 $\mu \mathrm{m} \times 23-26 \mu \mathrm{m}(\bar{x}=37.2 \times 25.5 \mu \mathrm{m}, \mathrm{n}=20)$, hyaline, unicellular, ellipsoid, with granular cytoplasm, smooth walled.

Material examined - MOZAMBIQUE, Zumbo, on unidentified bark, May 1913, A. Cruz (SF49313).

Economic significance - The asexual genus Botryochora consists of species that cause numerous leaf spot diseases on some plants (Clements 1931).

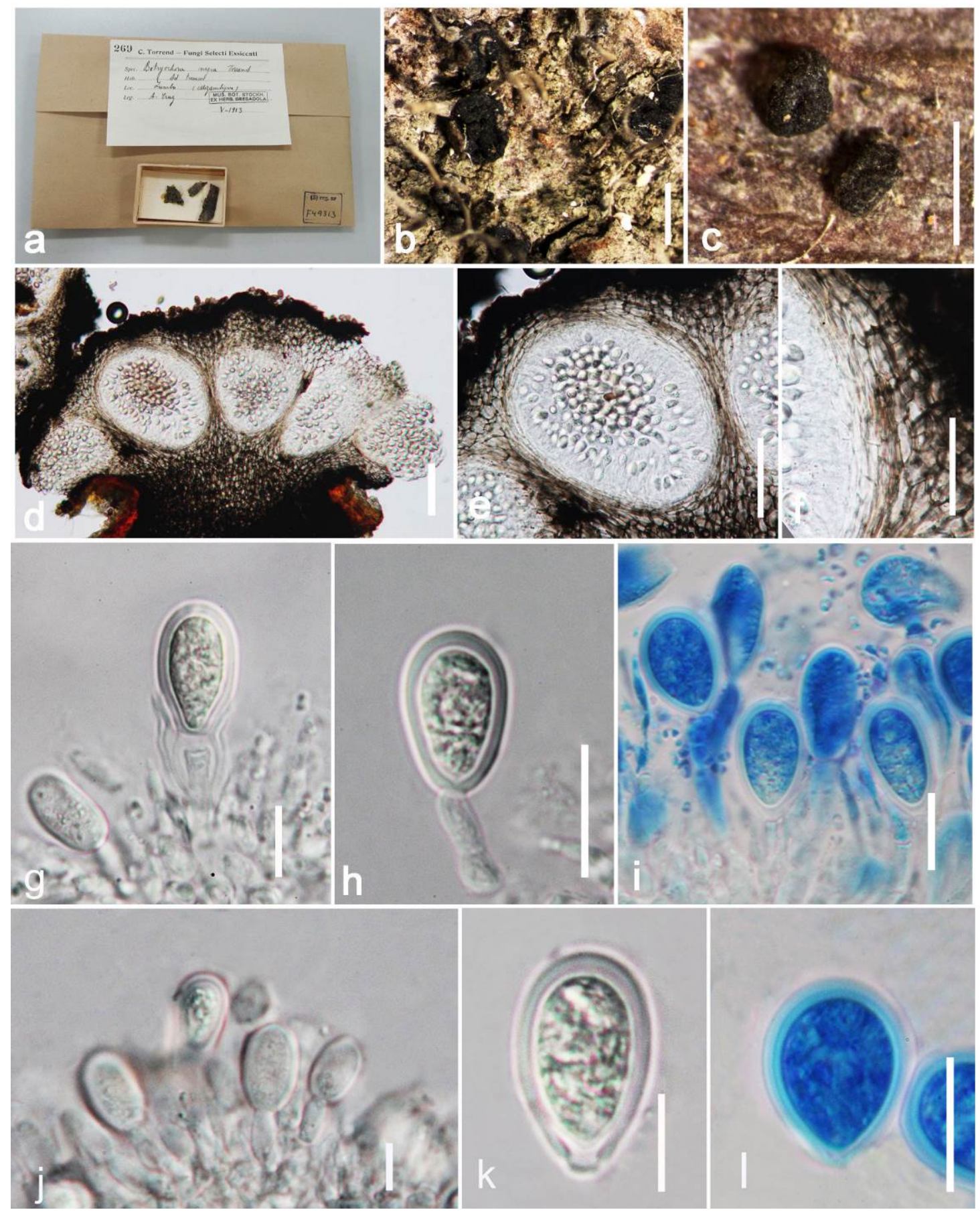


Figure 5 - Botryochora nigra (S-F49313). a-c Herbarium specimen and habit on substrate. d, e Section of conidiomata. f Peridium. g-j Conidiogeneous cells. $k$, l Conidia. Scale bars: b, c $=1 \mathrm{~mm}$, d, e $=100 \mu \mathrm{m}, \mathrm{f}=5 \mu \mathrm{m}, \mathrm{g}, \mathrm{j}, \mathrm{k}=20 \mu \mathrm{m}, \mathrm{h}, \mathrm{i}, \mathrm{l}=40 \mu \mathrm{m}$.

Pleosporales Luttr. ex M.E. Barr

Dothidotthiaceae Crous \& A.J.L. Phillips

Belizeana Kohlm. \& Volkm.-Kohlm., Bot. Mar. 30(3): 195 (1987)

Pathogenic or saprobic on Laguncularia sp. Sexual morph: Ascomata solitary, scattered, or clustered or somewhat gregarious, erumpent, subglobose, medium-sized, dark brown to black, pale brown on the sides, ostiolate, epapillate or shortly papillate. Peridium comprising a few layers of thin-walled cells of textura angularis, hyaline towards the inside, basal region giving rise to hyaline hyphal mass producing asci. Hamathecium of dense, ca. $2 \mu \mathrm{m}$ broad, filliform pseudoparaphyses, rarely branched, embedded in gelatinous matrix. Asci 8-spored, bitunicate, fissitunicate, broadly cylindrical to clavate, with a short pedicel, thick-walled, rounded at apex, with an ocular chamber. Ascospores uniseriate, partially overlapping, broadly ellipsoidal, hyaline when immature, pale brown to chestnut when mature, 1-septate, constricted at the septum, thick-walled, 2-layered, mature spores with tuberculate ornamentation between the two layers. Asexual morph: undetermined.

Type species - Belizeana tuberculata Kohlm. \& Volkm.-Kohlm.

Notes - The monotypic genus Belizeana was introduced by Kohlmeyer \& VolkmannKohlmeyer (1987) with Belizeana tuberculata as type species. The genus is characterized by distinct subglobose to ampulliform ascomata, eight-spored, cylindrical asci and one-septate, thick, walled, pale brown ascospores. Belizeana was previously accommodated in Pleosporaceae by Volkmann-Kohlmeyer (1987). Later, it was transferred to Elsinoaceae by Lumbsch \& Huhndorf (2010). Recently, Belizeana was accepted as a genus in Dothideales incertae sedis (Jones et al. 2015). The asexual morph is coelomycetes (Kohlmeyer \& Volkmann-Kohlmeyer 1987). Cultures and sequences are unavailable for the type species. We re-examined the type specimen of $B$. tuberculata from IMS under no. 4209 and found comparable morphological characters to Dothidotthia symphoricarpi, such as subglobose, dark brown to black ascomata, clavate to cylindrical asci and 1-septate, ellipsoidal, pale brown ascospores. Based on morphological characters, we transfer the genus Belizeana to Dothidotthiaceae, Pleosporales.

Belizeana tuberculata Kohlm. \& Volkm.-Kohlm., Bot. Mar. 30(3): 196 (1987)

Fig. 6

Index Fungorum number: IF 130737; Facesoffungi number: FoF 06219

Pathogenic or saprobic on Laguncularia sp. Sexual morph: Ascomata 165-310 $\mu \mathrm{m}$ high $\times$ 155-295 $\mu \mathrm{m}$ diam., solitary, scattered, or clustered or somewhat gregarious, erumpent, subglobose, medium-sized, dark brown to black, pale brown on the sides, ostiolate, epapillate or shortly papillate. Peridium 25-35 $\mu \mathrm{m}$ wide, comprising a few layers of thin-walled cells of textura angularis, hyaline towards the inside, basal region giving rise to hyaline hyphal mass producing asci. Hamathecium of dense, ca. $2 \mu \mathrm{m}$ broad, filliform pseudoparaphyses, rarely branched, embedded in gelatinous matrix. Asci $135-160 \mu \mathrm{m} \times 20-30 \mu \mathrm{m}(\bar{x}=163 \times 25 \mu \mathrm{m}, \mathrm{n}=10)$, 8spored, bitunicate, fissitunicate, broadly cylindrical to clavate with a short pedicel, thick-walled, rounded at apex with an ocular chamber. Ascospores 21-26 $\mu \mathrm{m} \times 13-18 \mu \mathrm{m}(\bar{x}=22 \times 15 \mu \mathrm{m}, \mathrm{n}=$ 10), uniseriate, partially overlapping, broadly ellipsoidal, hyaline when immature, pale brown to chestnut when mature, 1-septate, constricted at the septum, thick-walled, 2-layered, mature spores.

Material examined - AUSTRALIA, New South Wales, Towra Point, Botany Bay, trunk of eroded tree with oysters and shipworms, intertidal zone, 23 August 1981, L. Kohlmeyer (IMS Herb. J. Kohlmeyer No. 4209, paratype).

Economic significance - The genus Belizeana comprises marine fungi and was reported to cause leaf spots and diseases of Rhizophora mucronata (Rhizophoraceae) (Ossler 2010).

Lophiotremataceae K. Hiray. \& Kaz. Tanaka 
Koordersiella Höhn., Sber. Akad. Wiss. Wien, Math.-naturw. Kl., Abt. 1 118: 833 (1909)

Synonyms listed in Index Fungorum (2019), Ascohansfordiellopsis D. Hawksw., Keratosphaera H.B.P. Upadhyay, Phanerococcus Theiss. \& P. Syd. (not confirmed in this study).

Saprobic on leaves of Urostigma vogelii Miq. Sexual morph: Ascomata regular, small, subglobose to globose, scattered, slightly carbonaceous. Peridium thick, carbonaceous. Hamathecium numerous, filamentous, septate, branched, anastomosing, trabeculate pseudoparaphyses. Asci 8-spored, fissitunicate, cylindrical to clavate, with a short pedicel or sessile, rounded at the apex, with an ocular chamber. Ascospores bi or tri-seriate, straight or slightly curved, fusiform to cylindrical, spindle-shaped, and rounded at both ends or slightly pointed, 4-8 celled, multi-septate, hyaline, without a gelatinous sheath. Asexual morph: Undetermined.

Type species - Koordersiella javanica Höhn.

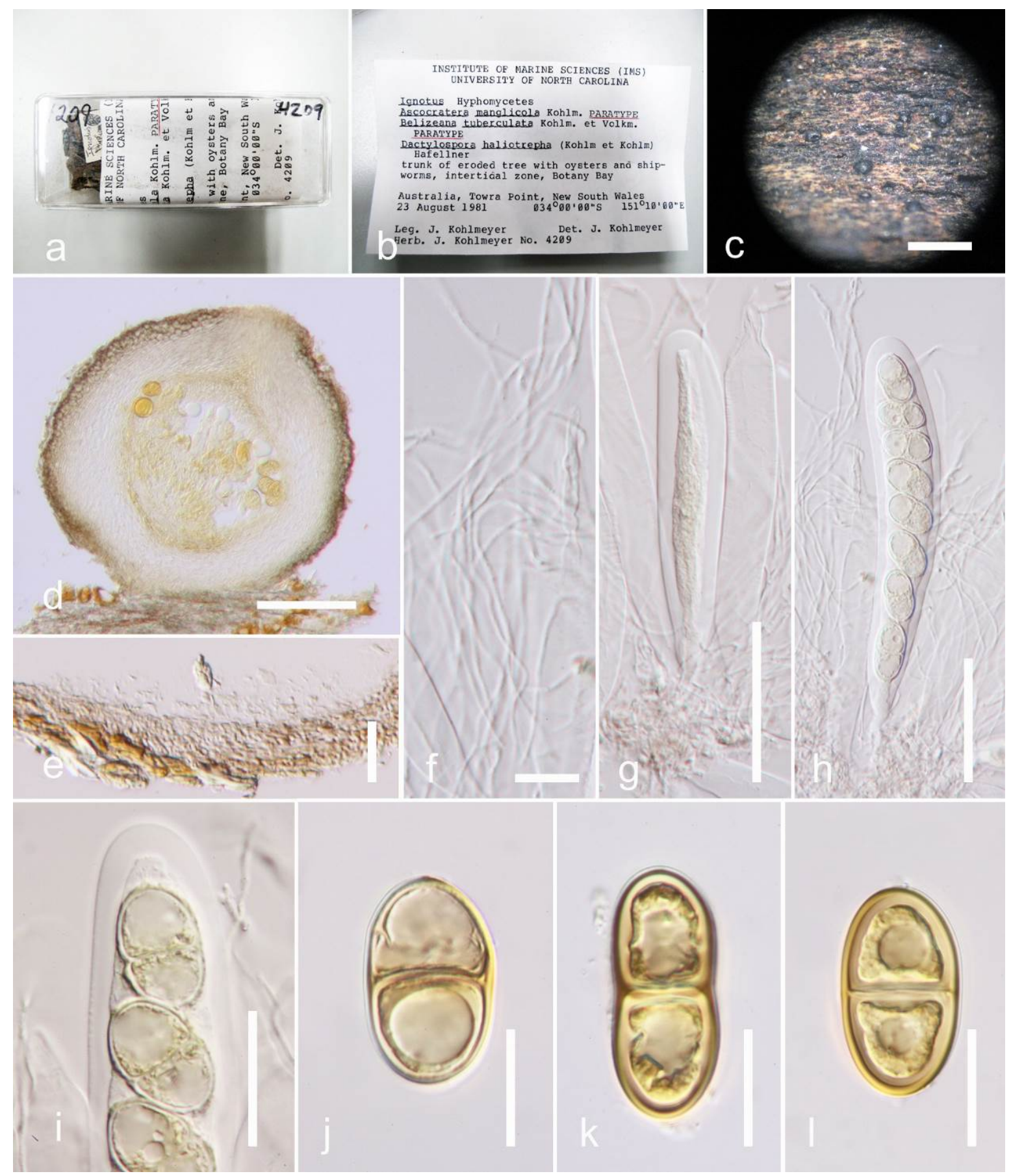

Figure 6 - Belizeana tuberculata (IMS from Herb. J. Kohlmeyer No. 4209, paratype) a-c Herbarium specimen and habit on substrate. $d$ Section of an ascoma. e Peridium $\mathrm{f}$ Hamathecium. g- 
h Asci. i Ocular chamber. $\mathrm{j}-1$ Ascospores. Scale bars: $\mathrm{c}=1 \mathrm{~mm}, \mathrm{~d}, \mathrm{~g}, \mathrm{~h}=100 \mu \mathrm{m}, \mathrm{e}, \mathrm{f}=20 \mu \mathrm{m}, \mathrm{i}=$ $50 \mu \mathrm{m}, \mathrm{j}-1=10 \mu \mathrm{m}$.

Notes - The lichenicolous genus Koordersiella was introduced by Höhnel (1909) to accommodate type species Koordersiella javanica. The latter was found on leaves of Urostigma vogelii Miq. in Java. The genus is characterized by regular, small black perithecia, with a multilayered perithecial wall. Asci are thin-walled, sessile consisting of four to eight spores. Ascospores are hyaline, cylindric spindle-shaped. Hawksworth (2016) considered the type species of Koordersiella, K. javanica, and the type species of Hansfordiellopsis, $H$. aburiensis (now regarded as a synonym of $K$. insectivora), to be congeneric. Currently, three species are accommodated in the genus Koordersiella (Wijayawardene et al. 2014). The asexual morph is unknown. Koordersiella was placed in Dothideomycetes genera incertae sedis (Lumbsch \& Huhndorf 2010, Kirk et al. 2013, Rossman et al. 2016). Cultures and sequences are unavailable. We illustrate the characters of the genus Koordersiella by re-examining the type specimen under the code FH 00301501 from FH herbarium. The type species of Koordersiella seems to resemble species of Lophiotremataceae in having small ascomata, clavate asci, and several septate hyaline ascospores. Thus, we tentatively place the genus Koordersiella in Lophiotremataceae based on morphology until further re-collected.

Koordersiella javanica Höhn., Sber. Akad. Wiss. Wien, Math.-naturw. Kl., Abt. 1 118: 833 (1909)

Fig. 7

Index Fungorum number: IF 174412; Facesoffungi number: FoF 06248

Saprobic on leaves of Urostigma vogelii. Sexual morph: Ascomata 19-29 $\mu \mathrm{m}$ high $\times 28-30$ $\mu \mathrm{m}$ diam. $(\bar{x}=23.7 \times 29.3 \mu \mathrm{m}, \mathrm{n}=20)$, regular, small, subglobose to globose, scattered, slightly carbonaceous. Peridium thick, carbonaceous and could not be observed. Hamathecium of filamentous, numerous, septate, branched, anastomosing trabeculate pseudoparaphyses. Asci 83-95 $\mu \mathrm{m} \times 14-16 \mu \mathrm{m}(\bar{x}=89.4 \times 15.7 \mu \mathrm{m}, \mathrm{n}=20), 8$-spored, fissitunicate, cylindrical to clavate, with a short pedicel or sessile, rounded at the apex, with an ocular chamber. Ascospores 18-20 $\mu \mathrm{m} \times 3-5$ $\mu \mathrm{m}(\bar{x}=19.7 \times 4.2 \mu \mathrm{m}, \mathrm{n}=20), 2$ or 3-seriate, straight or slightly curved, fusiform to cylindrical, spindle-shaped, and rounded at both ends or slightly pointed, 4-8 celled, multi-septate, hyaline, without a gelatinous sheath. Asexual morph: Undetermined.

Notes - The perithecial wall of Koordersiella javanica could not be observed from the specimen that we studied. However, from the original description, the peridium is described as 'having a thickness of 20 to $25 \mu \mathrm{m}$ on the top and $15 \mu \mathrm{m}$ below, laterally 40 to $45 \mu \mathrm{m}$, multi layered with the inner layer comprising hyaline cells of textura angularis'. The perithecia are usually located on a very delicate, circular, different broad basal membrane (Hypothallus), which consists of thin delicate hyphae (Fig. 7).

Material examined - JAVA, Kulturtuin of Tjeukemeer near Buitenzorg, on leaves of Urostigma vogelii (Moraceae), 1 January 1993, F. Höhnel (FH 00301652, holotype).

Economic significance - None has been reported.

\section{Massarinaceae Munk}

Byssothecium Fuckel, Bot. Ztg. 19(no. 35): 251 (1861)

Saprobic or parasitic on Medicaginis sativae. Sexual morph: Ascomata pseudothecioid solitary, scattered, or in groups, immersed, semi-immersed to erumpent, globose to subglobose, black, apex with a short papilla. Peridium coriaceous, consisting of thick-walled, brown cells of textura angularis. Hamathecium composed of pseudoparaphyses, embedded in mucilage, branching, septate and anastomosing between and above the asci. Asci 8-spored, bitunicate, fissitunicate, cylindro-clavate, slightly curved when immature, pedicellate. Ascospores biseriate to uniseriate, fusiform, hyaline when immature, dark brown at maturity, 3- trans-septate, and variously ornamented. Asexual morph: Undetermined.

Type species - Byssothecium circinans Fuckel 
Notes - The genus Byssothecium was introduced by Fuckel (1861) with the type species $B$. circinans. The latter was described as a saprobe or parasite of Medicago sativa (Semeniuk 1983) and a Pleospora-type centrum was observed (Boise 1983). A chaetophoma-like anamorph is reported in culture, however, no culture or herbarium specimen is listed (Boise 1983). Byssothecium was considered as closely related to Teichospora (Boise 1983). Later, it was accepted as a genus in Massarinaceae by Zhang et al. (2009). Some studies showed that Byssothecium was distinct from Massarinaceae and was placed in Dothideomycetes genera incertae sedis (Lumbsch \& Huhndorf 2010, Wijayawardene et al. 2014). However, in the phylogenetic analysis done by Chethana et al. (2015) and Thambugala et al. (2015), Byssothecium clustered in Massarinaceae. Currently, the genus consists of eight species (Index fungorum 2019). The asexual morph is coelomycetous (Wijayawardene et al. 2017). Cultures and sequences are available for B. circinans however, it could not be accommodated in any family so far (Wijayawardene et al. 2018). We examined the isotype specimen of $B$. circinans and according to morphological characters, $B$. circinans share morphological similarities to species in Trematosphaeriaceae such as subglobose, black, coriaceous ascomata, thick-walled cells of textura angularis, septate, cellular pseudoparaphyses, embedded in mucilage, branching and anastomosing between and above the asci, cylindric-clavate bitunicate asci and brown fusiform ascospores. But, based on a megablast search using the LSU sequence of Byssothecium circinans, the closest matches in NCBI's GenBank nucleotide database were Helminthosporium juglandinum (L97), Helminthosporium juglandinum (L118), Helminthosporium juglandinum (L101) with 100\%, 99\%, 99\% similarities respectively with 0\% gaps. Phylogenetic analyses of the putative strain of Byssothecium circinans (CBS 675.92) available in GenBank shows that Byssothecium forms a lineage basal to Pseudodidymosphaeria spartii (CBS 183.58) (Fig. 8). Byssothecium resembles Pseudodidymosphaeria in having semiimmersed ascomata, however, it differs from other morphological characters. The genus Byssothecium rather resembles species of Pseudosplanchonema in having pseudothecioid ascomata and cylindro-clavate asci but differs in ascospores characters (3- trans-septate vs 1-sub-median septate, pseudosepta between the guttules). We therefore, place Byssothecium in Massarinaceae.

Byssothecium circinans Fuckel, Bot. Ztg.19 (no. 35): 251 (1861)

Fig. 9

Index Fungorum number: IF 165669; Facesoffungi number: FoF 06226

Saprobic or parasitic on Medicaginis sativae. Sexual morph: Ascomata pseudothecioid 250$350 \mu \mathrm{m}$ high, $200-300 \mu \mathrm{m}$ diam. $(\bar{x}=256.3 \times 260.2 \mu \mathrm{m}, \mathrm{n}=10)$, solitary, scattered, or in groups, immersed, semi-immersed to erumpent, globose to subglobose, black, apex with a short papilla. Peridium 16-40 $\mu \mathrm{m}$ wide, coriaceous, consisting of thick-walled, brown cells of textura angularis. Hamathecium 2-5 $\mu \mathrm{m}$ wide comprises pseudoparaphyses, embedded in mucilage, branching, septate and anastomosing between and above the asci. Asci 54-69 $\mu \mathrm{m} \times 8-13 \mu \mathrm{m}(\bar{x}=61.3 \times 11.3$ $\mu \mathrm{m}, \mathrm{n}=10$ ), 8-spored, bitunicate, fissitunicate, cylindro-clavate, slightly curved when immature, pedicellate. Ascospores 35-44 $\mu \mathrm{m} \times 12-16 \mu \mathrm{m}(\bar{x}=41.2 \times 14.5 \mu \mathrm{m}, \mathrm{n}=10)$, uni- to bi-seriate, fusiform, hyaline when immature, dark brown at maturity, trans-septate and variously ornamented. Asexual morph: undetermined.

Material examined - GERMANY, Europe, F. rhen. 730c, on Medicago sativa (Fabaceae), Fuckel, (B70 0014084, isotype); Fungi rhenani 730 (G-K 18364); Herbier Boissier 339 (G-K 18366); F. sel, exs. 259, on Medicago sativa (Fabaceae) (G-K 18367).

Economic significance - The genus Byssothecium has been reported to cause leaf spots on Quercus sp. (Fagaceae) in Iran (Pourmoghaddam et al. 2015).

\section{Pleosporaceae Nitschke}

Gibbago E.G. Simmons, Mycotaxon 27: 108 (1986)

Saprobic or pathogenic on leaves and wood. Sexual morph: Undetermined. Asexual morph: Conidiophores straight or curved, mostly unbranched or rarely branched, pale brown, septate and solitary or 2-4 loosely fasciculate, erect, simple with a single apical conidiogenous locus which proliferate by means of a secondary conidiophore that arises immediately below the 
apical cell of the existing conidiophore, septate, slightly pigmented. Conidiogenous cells swollen at the apex, holoblastic, polyblastic, sympodial, hyaline to medium or dark brown, with occasionally 1-5 apical proliferations. Conidia formed singly at the tip of conidiogenous cell, sometimes catenate, pale to dark brown with the densely pustular wall, mostly ovoid to oblong, rounded at the base and round to conical at the apex, initially solitary, ellipsoid, beakless, pigmented, becoming transversely and longitudinal septate, with apical cells swelling slightly and producing secondary conidia similar to initial ones with distinct constriction at the median septum (Simmons 1986).

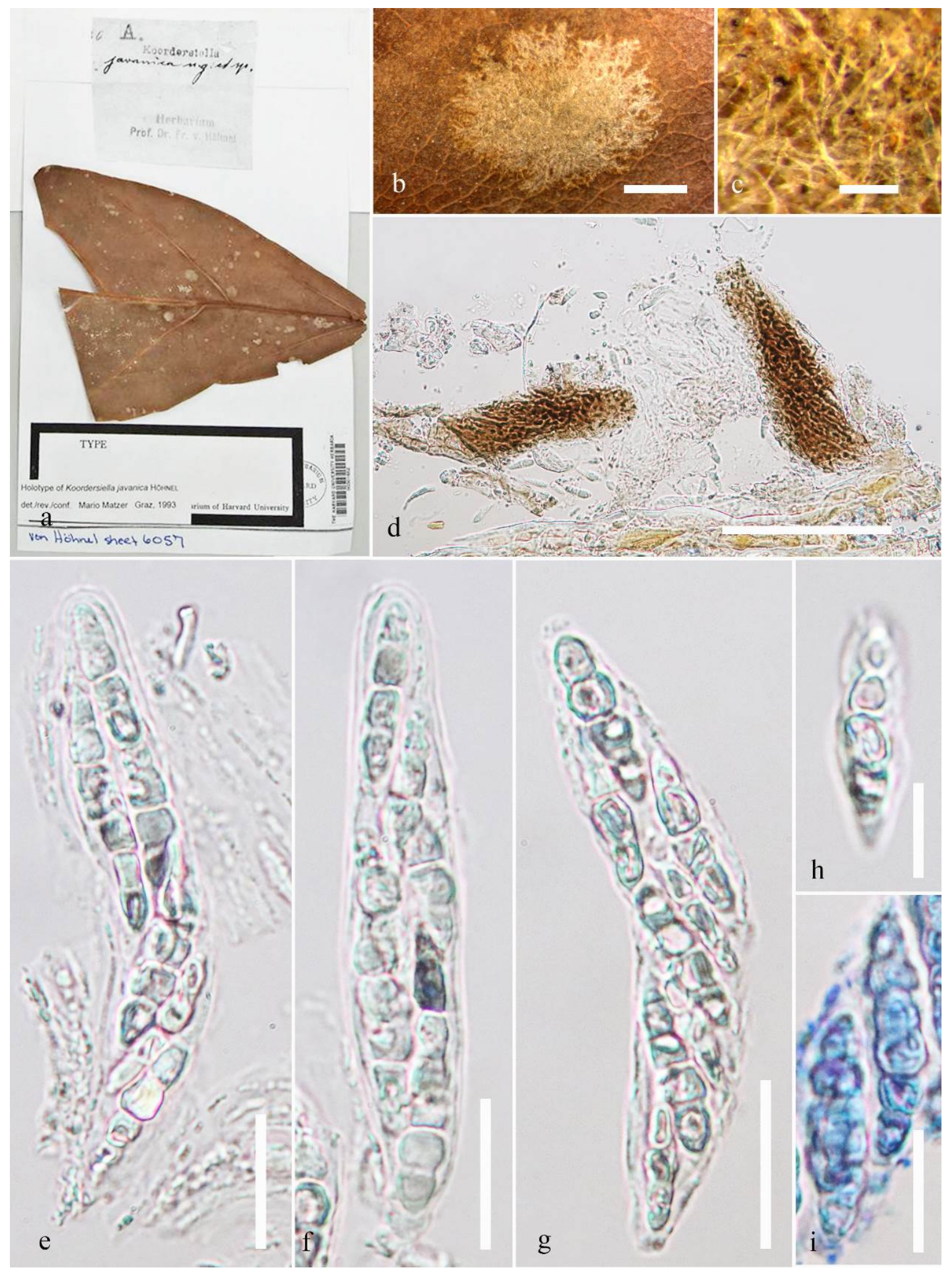


Figure 7 - Koordersiella javanica (FH 00301652, holotype). a Details of herbarium material. b, c Habit and appearance of ascomata on host surface. d Section of ascoma. e-g Asci. h, i Ascospores. Scale bars: $\mathrm{b}=500 \mu \mathrm{m}, \mathrm{c}=200 \mu \mathrm{m}, \mathrm{d}=50 \mu \mathrm{m}, \mathrm{e}-\mathrm{g}=20 \mu \mathrm{m}, \mathrm{h}, \mathrm{i}=10 \mu \mathrm{m}$.

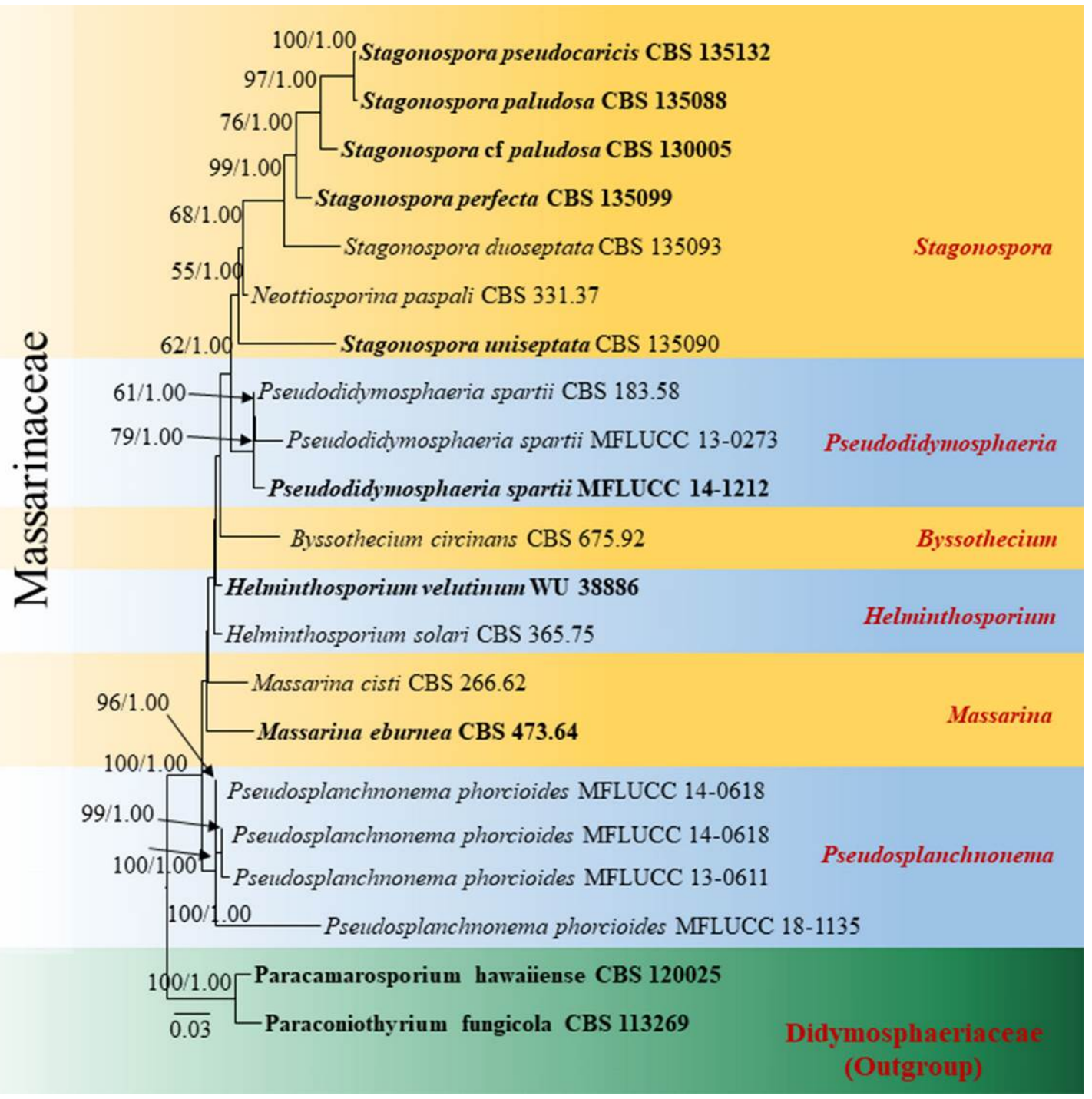

Figure 8 - Phylogram generated from maximum likelihood analysis based on combined LSU, SSU and BTUB sequence data. Related sequences were retrived from Liu et al. (2017). Twenty-one strains are included in the combined gene analyses comprising 2327 characters after alignment (856 characters for LSU, 1058 characters for SSU and 411 characters for BTUB). Paracamarosporium hawaiiense (CBS 120025) and Paraconiothyrium fungicola (CBS 113269) are used as the outgroup taxon. The tree topology of the Bayesian analysis was similar to the maximum likelihood analysis. The best RaxML tree with a final likelihood value of -7593.818950 is presented. The matrix had 535 distinct alignment patterns, with $30.91 \%$ undetermined characters or gaps. Estimated base frequencies were as follows: $\mathrm{A}=0.254460, \mathrm{C}=0.214516, \mathrm{G}=0.284400, \mathrm{~T}=0.246625$; substitution rates $\mathrm{AC}=1.248767, \mathrm{AG}=2.513663, \mathrm{AT}=1.269748, \mathrm{CG}=0.839642, \mathrm{CT}=$ 4.977442, GT $=1.000000$; gamma distribution shape parameter $\alpha=0.917153$. Bootstrap values for maximum likelihood equal to or greater than 50 and Bayesian posterior probabilities equal or greater than 0.95 are placed above or below the branches, respectively. Ex-type strains are in bold and black. The newly generated sequences are indicated in blue.

Type species - Gibbago trianthemae E.G. Simmons

Notes - The monotypic genus Gibbago was introduced by Simmons for the type species Gibbago trianthemae. The latter was isolated from leaves of Trianthema portulacastrum. The 
genus is characterized by loosely fasciculate, erect conidiophores, polyblastic, sympodial conidiogenous cells and ellipsoid, beakless, transversely and longitudinally septate brown conidia. Its sexual morph has never been reported. We have re-studied the isotype specimen of Gibbago trianthemae under the code NY00945973.

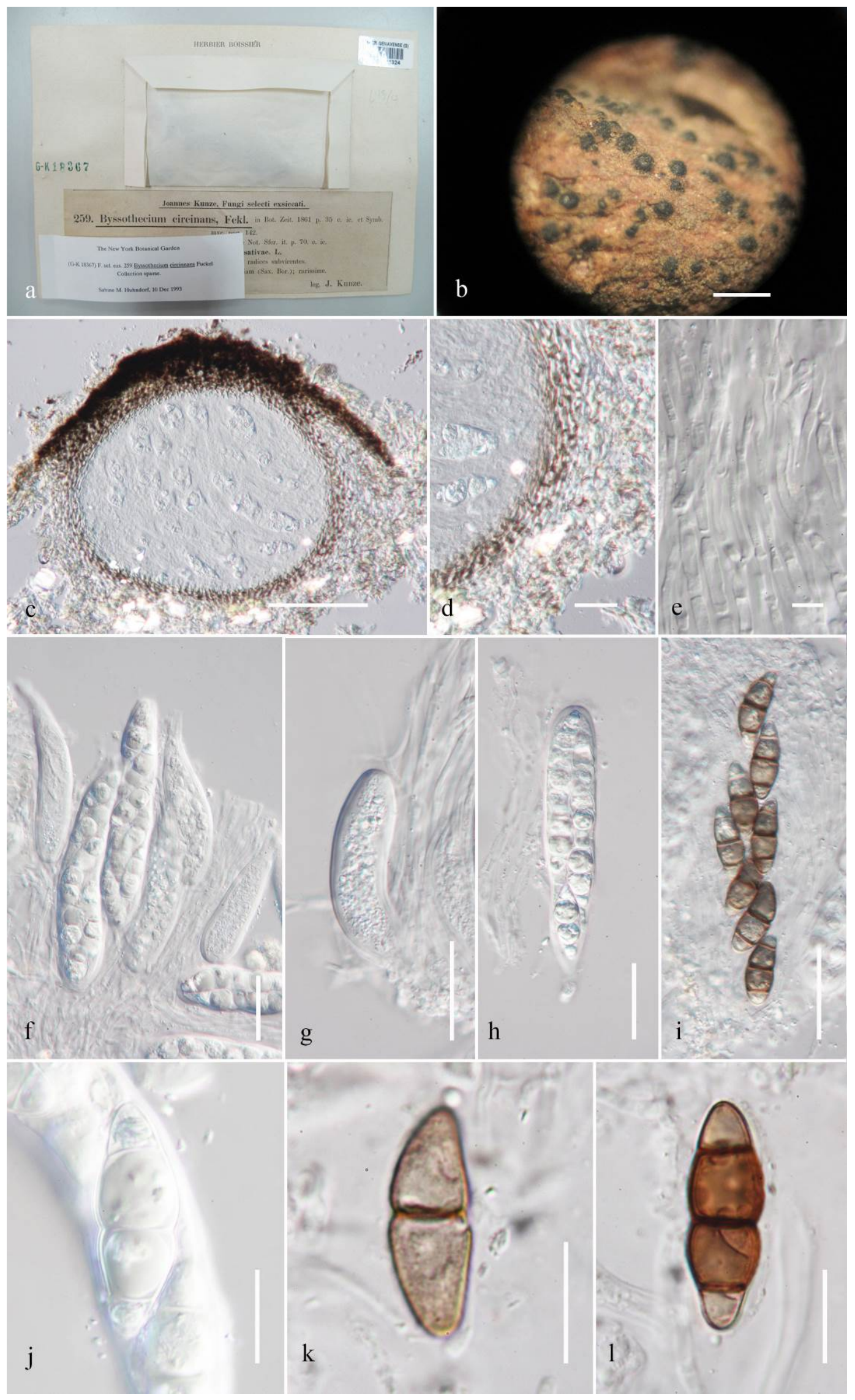


Figure 9 - Byssothecium circinans (G-K 18367) a, b Herbarium specimen and habit on host. c Section of ascoma. d Peridium. e Hamathecium. f Asci embedded in pseudoparaphyses. g-i Asci. j-l Ascospores. Scale bars: $\mathrm{b}=500 \mu \mathrm{m}, \mathrm{c}=100 \mu \mathrm{m}, \mathrm{d}, \mathrm{e}, \mathrm{g}, \mathrm{j}-\mathrm{l}=20 \mu \mathrm{m}, \mathrm{f}, \mathrm{h}-\mathrm{i}=50 \mu \mathrm{m}$.

The genus Gibbago was accommodated in Pleosporaceae by Simmons (1986) based on its morphological similarities with the genus Alternaria, Embellisia, Ulocladium and Stemphylium and this was followed by Wijayawardene et al. (2014). Only ITS sequence data is available for the putative strains of Gibbago trianthemae GT-VM and NFCCI 1886. In a previous study by Ariyawansa et al. (2015b), the strains Gibbago trianthemae GT-VM and NFCCI 1886 formed a distinct lineage basal to Paradendryphiella and Pleospora with low boostrap support. In our study, after nucleotide blast using the Basic Local Alignment Search Tool, DNA sequence of strains of Gibbago trianthemae were highly similar to species in the family Pleosporaceae. In the phylogenetic analyses of the ITS sequences, the two strains Gibbago trianthemae GT-VM and NFCCI 1886 formed a independent clade basal to Exserohilum and Setosphaeria with moderate bootstrap support (Fig. 10). We therefore, transfer Gibbago to Pleosporaceae following Ariyawansa et al. (2015b).

Gibbago trianthemae E.G. Simmons, Mycotaxon 27: 108 (1986)

Fig. 11, 12

Index Fungorum number: IF130298; Facesoffungi number: FoF00522

Saprobic or pathogenic on leaves and leaf stalks of Trianthema portulacastrum (Aizoaceae). Sexual morph: unknown. Asexual morph: Conidiophores 51-94 $\mu \mathrm{m} \times 3-7 \mu \mathrm{m}(\bar{x}=59.6 \times 6.1 \mu \mathrm{m}$, $\mathrm{n}=10$ ), straight or curved, mostly unbranched or rarely branched, pale brown, septate and up to 80 $\mu \mathrm{m}$ in length, solitary or 2-4 loosely fasciculate, erect, simple with an apical conidiogenous locus which proliferates by means of a secondary conidiophore that arises immediately below the apical cell of the existing conidiophore, septate, slightly pigmented. Conidiogenous cells swollen at the apex and hyaline to medium or dark brown, polyblastic, sympodial, 6-8 $\mu \mathrm{m}$ in wide and occasionally 1-5 apical proliferations. Conidia 38-40 $\mu \mathrm{m} \times 17-19 \mu \mathrm{m}(\bar{x}=39.2 \times 18.3 \mu \mathrm{m}, \mathrm{n}=$ 10 ), formed singly at the tip of conidiogenous cell, pale to dark brown with the densely pustular wall, mostly ovoid to oblong, rounded at the base and round to conical at the apex, initially solitary, sometimes becoming catenate, ellipsoid, beakless, pigmented, becoming transversely and longitudinal septate, with apical cells swelling slightly and producing secondary conidia similar to initial ones with distinct constriction at the median septum.

Material examined - NORTH AMERICA, USA, Brazos Co., Texas A. \& M. Univ. Expt. Farm, on leaves and leaf stalks of Trianthema portulacastrum (Aizoaceae), 27 August 1967, E.G. Simmons (NY 00945973, isotype).

Economic significance - The fungus in the genus Gibbago is a fungal pathogen or bioherbicide against the weed horse purslane (Trianthema portulacastrum L.) (Akhtar 2013, Gandipilli \& Kumar 2018).

Tetraplosphaeriaceae Kaz. Tanaka \& K. Hiray.

Byssolophis Clem., in Clements \& Shear, Gen. fung., Edn 2 (Minneapolis): 83, 286 (1931)

Saprobic on decaying wood. Sexual morph: Ascomata hysterothecial, superficial or sunken in substrate, oval to elongate, or globose to subglobose, dark brown to black, carbonaceous, glabrous, straight or curved, with a subiculum, with brown hyphae. Ostiole slit-like, with a small to large, flat, crest-like apex. Peridium thick at the sides, broad at the apex and thinner at the base, dark brown, comprising a single stratum of dark brown cells of textura angularis in the inside and thinwalled cells of textura prismatica in the exterior part. Hamathecium comprising cylindrical to filiform pseudoparaphyses in a gelatinous matrix. Asci 8-spored, bitunicate, fissitunicate, elongate cylindric-clavate, straight or slightly curved, short-pedicellate, apically rounded, with an ocular chamber. Ascospores overlapping bi-seriate, narrowly fusiform to broadly cylindrical, straight or 
slightly curved, 1-3-septate, hyaline to pale brown, smooth, surrounded by a narrow appendagelike sheath. Asexual morph: Undetermined.

Type species - Byssolophis byssiseda (Flageolet \& Chenant.) Clem. 1931

Notes - The monotypic genus Byssolophis is based on B. byssiseda found on branches of Carpini rigny. Currently, two more species are accommodated in this genus namely, B. ampla (Berk. \& Broome) L. Holm and B. sphaerioides (P. Karst.) E. Müll. (Holm 1986, Müller \& von Arx 1962).

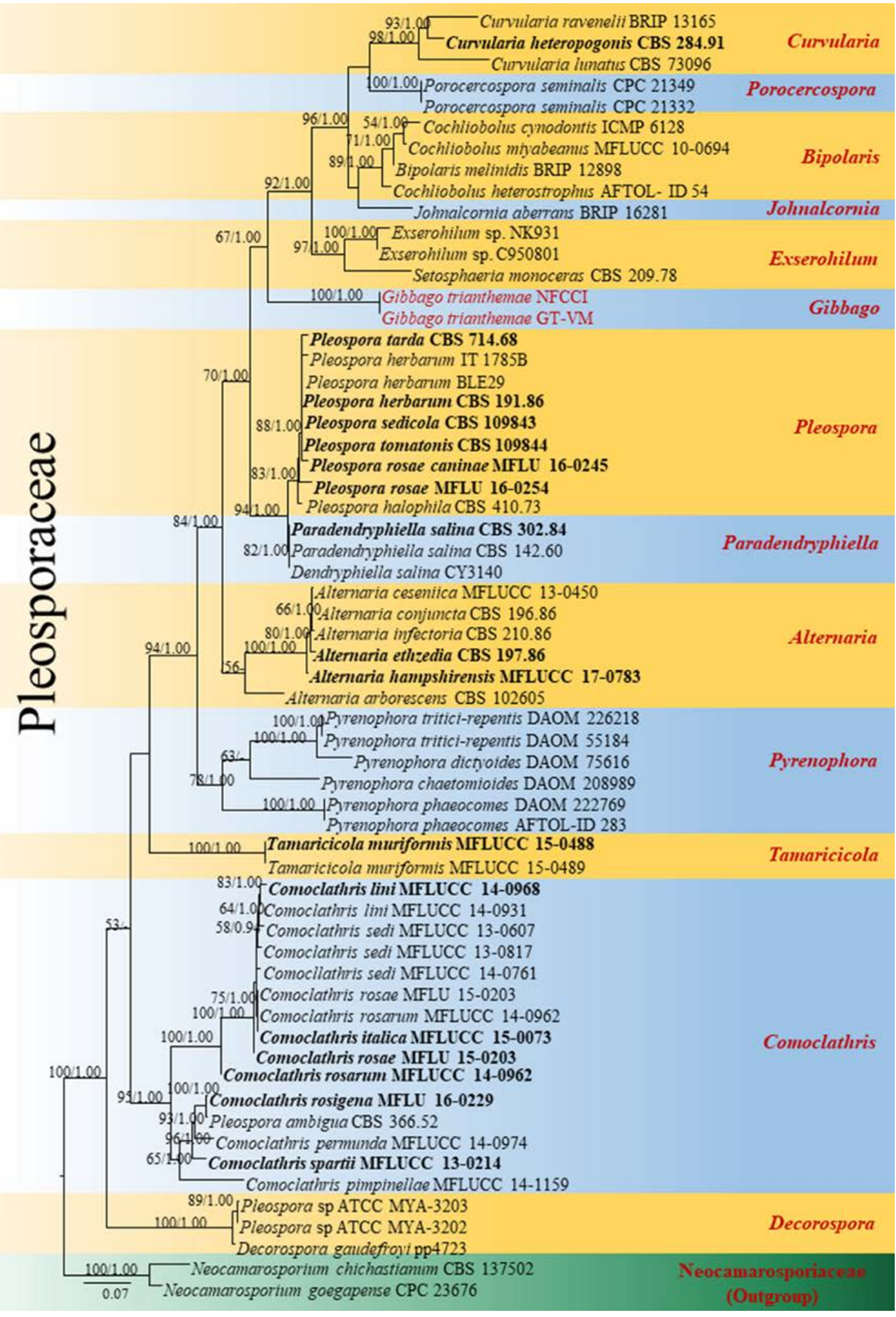


Figure 10 - Phylogram generated from maximum likelihood analysis based on ITS sequence data retrieved from the GenBank. Related sequences were referred to Wanasinghe et al. (2018). Sixteenone taxa are included in the genes sequence analyses which comprise 618 characters after alignment. Neocamarosporium chichastianum (CBS 137502), Neocamarosporium goegapense (CPC 23676) are used as the out-group taxon. Maximum likelihood (ML) analysis was conducted in the CIPRES Science Gateway V. 3.3. The best sorting RAxML tree with a final likelihood value of -5725.732510 is presented. Estimated base frequencies were as follows: $\mathrm{A}=0.231229, \mathrm{C}=$ $0.247168, \mathrm{G}=0.234507, \mathrm{~T}=0.287096$; substitution rates $\mathrm{AC}=1.411986, \mathrm{AG}=1.991610, \mathrm{AT}=$ $1.292870, \mathrm{CG}=0.994088, \mathrm{CT}=3.032473, \mathrm{GT}=1.000000$; gamma distribution shape parameter $\alpha$ $=1.220238$; proportion of invariant 0.455010 . ML bootstrap values $\geq 50 \%$ are given as the first set of numbers and approximate likelihood-ratio test (aLRT) $\geq 0.90$ values as the second set of numbers above the nodes. Voucher/strain numbers are given after the taxon names, the one from type material are indicated in bold face. Sequence of interest is indicated in red. The bar length indicates the number of nucleotide substitutions per site.

The asexual morph of this genus is unknown. Due to its uncertain taxonomic placement, the genus was placed in Dothideomycetes genera incertae sedis (Wijayawardene et al. 2014). Zhang et al. (2012) examined the type species of $B$. byssiseda and suggested similar morphological characters to species in Lophiostoma, but could not resolve the taxonomic placement. We reexamined another species, B. sphaerioides (Nyl. ex P. Karst.) E. Müll. from K herbarium under the code K (M) 164030 in which the ascomata, asci and ascospores showed morphology similar to Tetraplosphaeriaceae. We also carried out phylogenetic analysis with the strains of Byssolophis sphaerioides (IFRDCC 2053) using LSU, SSU, TEF and RPB2 sequences from GenBank. Byssolophis sphaerioides clusters as an independent lineage close to Quadricura septentrionalis and other members of the Tetraplosphaeriaceae (Pleosporales) with weak bootstrap support (Fig. 13). Therefore, we transfer the genus Byssolophis in Tetraplosphaeriaceae as ascomata are scattered to gregarious, immersed to superficial, gabrous or with brown hyphae, asci are cylindrical to clavate with a short pedicel and ascospores are 1-3-septate, hyaline to pale brown surrounded by a narrow appendage-like sheath.

Byssolophis sphaerioides (Nyl. ex P. Karst.) E. Müll., in Müller \& von Arx, Beitr. Kryptfl. Schweiz 11(no. 2): 341 (1962)

Fig. 14

$\equiv$ Hysterographium sphaerioides Nyl. ex P. Karst., Not. Sällsk. Fauna et Fl. Fenn. Förh. 11: 258 (1870) [1871]

Index Fungorum number: IF 569553; Facesoffungi number: FoF 06225

Saprobic on decaying wood. Sexual morph: Ascomata 105-238 $\mu \mathrm{m}$ high $\times 169-373 \mu \mathrm{m}$ diam $(\bar{x}=133.5 \times 346.9 \mu \mathrm{m}, \mathrm{n}=10)$, hysterothecial, superficial or sunken in substrate, oval to elongate, or globose to subglobose, dark brown to black, carbonaceous, glabrous, straight or curved, with a subiculum, with brown hyphae. Ostiole slit-like, with a small to large, flat, crest-like apex. Peridium 21- $45 \mu \mathrm{m}$ thick at the sides, broad at the apex and thinner at the base, dark brown, comprising a singlle stratum of dark brown cells of textura angularis in the inside and thin-walled cells of textura prismatica in the exterior part. Hamathecium comprising 1-1.9 $\mu \mathrm{m}$ wide, cylindrical to filiform pseudoparaphyses in a gelatinous matrix. Asci $50-89 \mu \mathrm{m} \times 8.7-8.9 \mu \mathrm{m}(\bar{x}=$ $74.5 \times 8.9 \mu \mathrm{m}, \mathrm{n}=10), 8$-spored, bitunicate, fissitunicate, elongate cylindric-clavate, straight or slightly curved, short-pedicellate, apically rounded, with an ocular chamber. Ascospores 18-26 $\mu \mathrm{m}$ $\times 5-6 \mu \mathrm{m}(\bar{x}=21 \times 6 \mu \mathrm{m}, \mathrm{n}=10)$ overlapping bi-seriate, narrowly fusiform to broadly cylindrical, straight or slightly curved, 1-3-septate, hyaline to pale brown, smooth, surrounded by a narrow appendage-like sheath. Asexual morph: Undetermined.

Material examined - Unknown, on decaying wood, ex herb C.E. Broome, 1886, (K (M) 164030, isotype).

Economic significance - None is reported. 
Pleosporales, genus incertae sedis

Homostegia Fuckel, Jb. nassau. Ver. Naturk. 23-24: 223 (1870) [1869-70]

Lichenicolous on thallus of Lichens. Sexual morph: Ascomata immersed to semi-immersed, black, solitary, scattered, or in small groups, discoid to rounded, carbonaceous, multilocular, wall black to grayish, roughened, dehiscence via irregular slit appearing on upper part of the wall. Locules globose to subglobose, forming a single layer within ascostromata. Peridium 1-2 layered, composed of highly pigmented cells of textura angularis, reddish-brown cells. Hamathecium dense with cellular hyaline, septate pseudoparaphyses. Asci 8-spored, bitunicate, fissitunicate, dehiscence not observed, obovoid to broadly cylindrical, forms short, broad, hamate shaped pedicel. Ascospores partially overlapping, fusiform to ellipsoidal to broadly ellipsoidal, brown to reddishbrown, 3-longitudinal septa, constricted at septa, slightly curved, smooth-walled. Asexual morph: Undetermined.

Type species - Homostegia adusta Fuckel

Notes - The genus Homostegia was introduced by Fuckel (1870). Homostegia adusta was isolated from the lichen Parmelia saxatilis in Germany. The genus is characterized by black multiloculate stromata and brown 3-septate and regularly asymmetric ascospores. Currently, the genus Homostegia comprises five species. The asexual morph is unknown. No cultures or molecular data are available. Doilom et al. (2018) studied the lectotype specimen, Homostegia piggotii and mentioned that the latter is the synonym of Homostegia adusta and retained the genus in Pleosporales, genera incertae sedis. In this study, we re-examined the holotype specimen of Homostegia adusta under the code G-322312/1 from G herbarium. Both Homostegia piggotii and Homostegia adusta are isolated from the same host namely Parmelia spp. and are characterized by multiloculate ascomata, 8-spored asci as well as dark brown, ellipsoidal to fusiform ascospores. These characters resemble species of the family Decampiaceae. However, we retain the genus in Pleosporales, genera incertae sedis until molecular data becomes available.

Homostegia adusta Fuckel, Jb. nassau. Ver. Naturk. 23-24: 223 (1870)

Fig. 15

Index Fungorum number: IF 243056; Facesoffungi number: FoF 06247

Lichenicolous on thallus of Parmelia saxatilis. Sexual morph: Ascomata 660-780 $\mu \mathrm{m}$ high, 645-750 $\mu \mathrm{m}$ diam., immersed to semi-immersed, black, solitary, scattered, or in small groups, discoid to rounded, carbonaceous, multilocular, wall black to grayish, roughened, dehiscence via irregular slit appearing on upper part of the wall. Locules $94-143 \mu \mathrm{m} \times 98-107 \mu \mathrm{m}(\bar{x}=108.9 \times$ $102.8 \mu \mathrm{m}, \mathrm{n}=10$ ), globose to subglobose, forming a single layer within ascostromata. Peridium 12 layered, composed of reddish-brown pigmented cells of textura angularis. Hamathecium dense with cellular hyaline, septate pseudoparaphyses. Asci 34-37 $\mu \mathrm{m} \times 14-17 \mu \mathrm{m}(\bar{x}=35.2 \times 16.2 \mu \mathrm{m}$, $\mathrm{n}=10$ ), 8-spored, bitunicate, fissitunicate dehiscence not observed, obovoid to broadly cylindrical, forms short, broad, hamate shaped pedicel. Ascospores 16-22 ×6-9 $\mu \mathrm{m}(\bar{x}=22.9 \times 6.6 \mu \mathrm{m}, \mathrm{n}=$ 15), partially overlapping, fusiform to ellipsoidal to broadly ellipsoid, sometimes reniform, brown to reddish-brown with 3 longitudinal septa, constricted at septa, slightly curved, smooth-walled. Asexual morph: Undetermined.

Material examined - GERMANY, Baden-Württemberg, on thallus of Parmelia saxatilis (Parmeliaceae), 1869 -1870, KWG Fuckel (G-322312/1, holotype).

Economic significance - Species of Homostegia are lichenicolous fungi that are pathogens, saprotrophs, and commensals. The genus Homostegia has been reported to cause small yellow, indefinite spots on leaves of Bambusa sp. in the Philippines (Stevenson \& John Albert 1926).

Dothideomycetes, families incertae sedis

Coccoideaceae Henn. ex Sacc. \& D. Sacc.

Englerodothis Theiss. \& Syd., Annls mycol. 13(3/4): 285 (1915)

Biotrophic, pathogenic or saprobic on living and dead leaves of Mayepea gilgiana. Sexual morph: Stroma black, hard, subglobose to hemispherical, hypostromatic, multiloculate, strongly convoluted and forming an elaborate geometrical pattern externally, in diam, the opposite upper 
surface of the leaf has sunken deeply in the extension of the stromata and has a dirty yellow discoloration, irregular in circumference, roundish, elongated or blister-shaped. Locules numerous and dense, spherical, elongate but merging with stromatal tissue, made up of dark brown angular cells with 1-2 paler inner layers, the apical part, flat and dark brown, splitting at maturity to expose asci and interascal tissue.

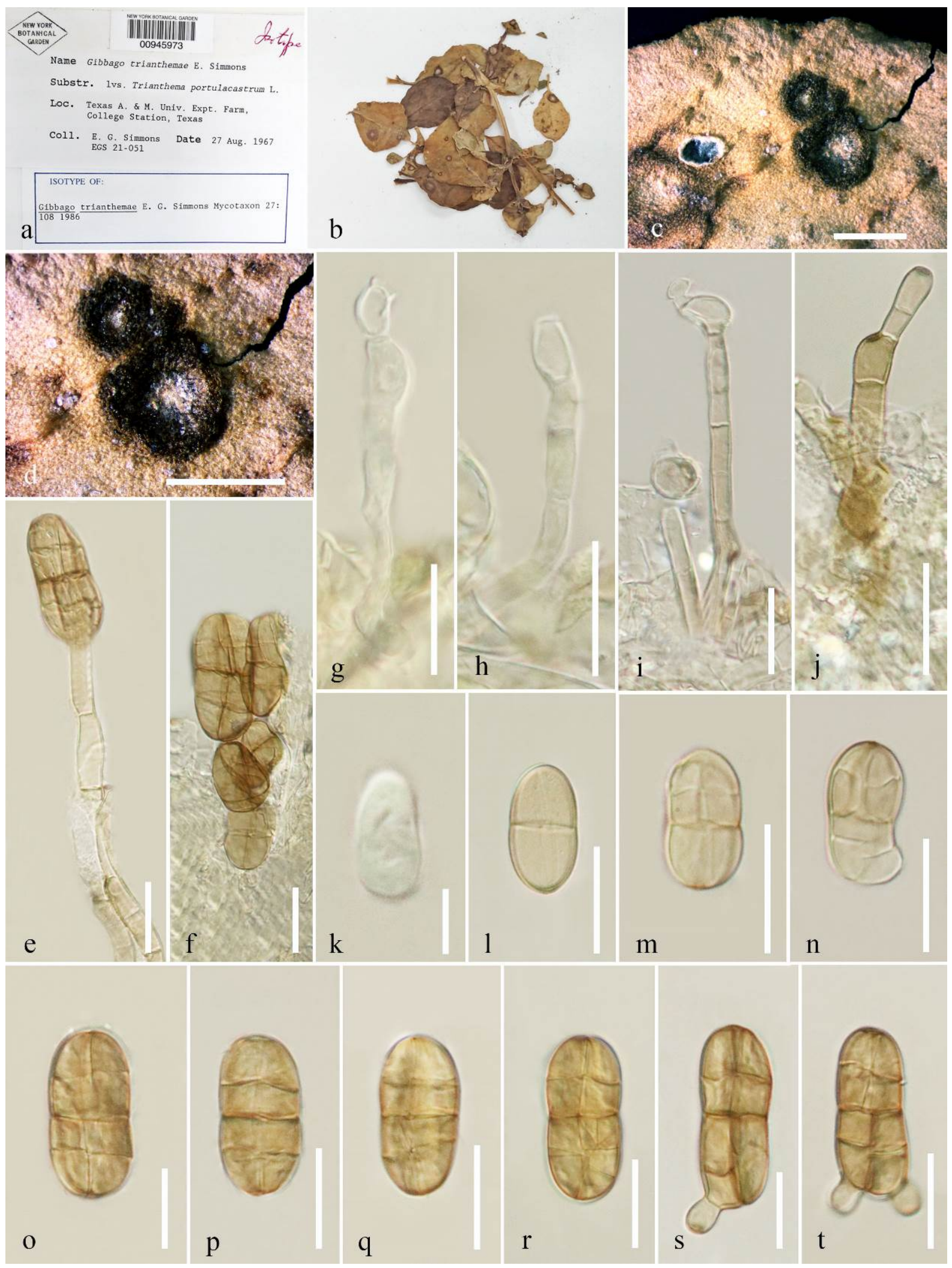

Figure 11 - Gibbago trianthemae (NY 00945973, isotype). a, b Herbarium material. c, d Appearance of conidiomata on host surface. $\mathrm{g}-\mathrm{j}$ Conidiophores and conidiogenesis. $\mathrm{k}-\mathrm{t}$ Conidia 
(arrows showing apical cells that have sporulated directly. e: Conidium have produced hyphal conidiophores) Scale bars: $\mathrm{c}, \mathrm{d}=2 \mathrm{~mm}, \mathrm{e}-\mathrm{t}=20 \mu \mathrm{m}, \mathrm{k}=5 \mu \mathrm{m}$.

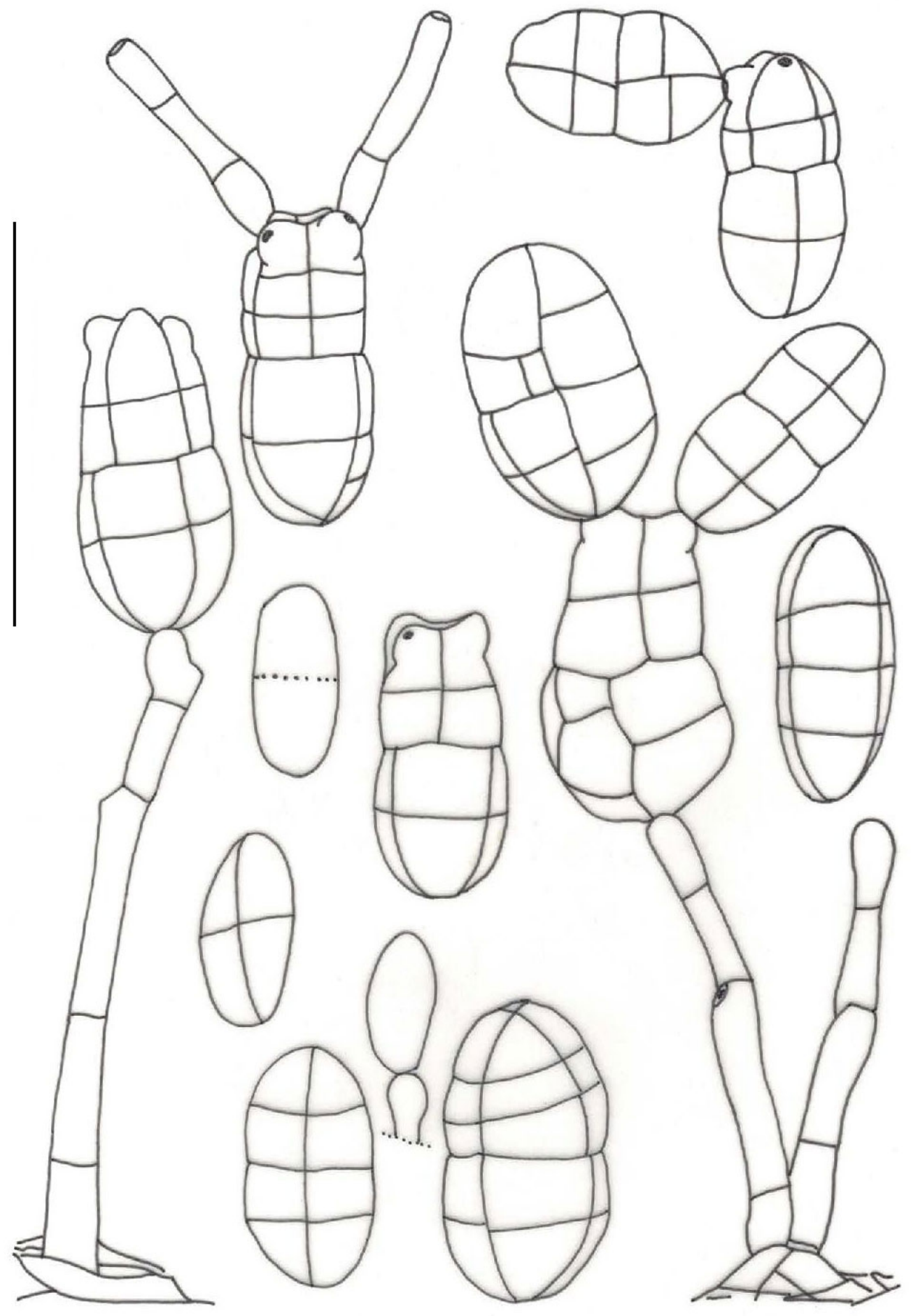

Figure 12 - Gibbago trianthemae (redrawn from Simmons 1986), conidia and conidophores; conidium at upper left exhibits two apical cells that have sporulated directly and two of them have produced hyphal conidiophores. Scale bar: $\mathrm{x}=50 \mu \mathrm{m}$.

Individual stomatal elements, the tissues surrounding the locules made up of brown to dark brown pseudoparenchymatous tissue, lower region of base composed of layers of small hyaline angular cells which tend to replace the cuticular lining of the leaf and penetrate between the distorted epidermal cells. Interascal tissue of cellular pseudoparaphyses, copiously filamentous, with each filament consisting of a chain of hyaline cells, the lower ones being compressed by the 
growing asci, the upper ones irregular in shape becoming pigmented and surrounded by a copious gelatinous matrix. Asci 8-spored, cylindrical to cylindric-clavate, the apex broadly rounded, the base tapering abruptly to a short stalk, fairly thick-walled at all stages, thickest at the apex, fissitunicate, without an apical ring. Ascospores arranged biseriately, 1-septate, slightly constricted at the septum, the upper cell with a rounded end, the lower one tapering, hyaline when young, pale brown at maturity, smooth-walled. Asexual morph: Undetermined.

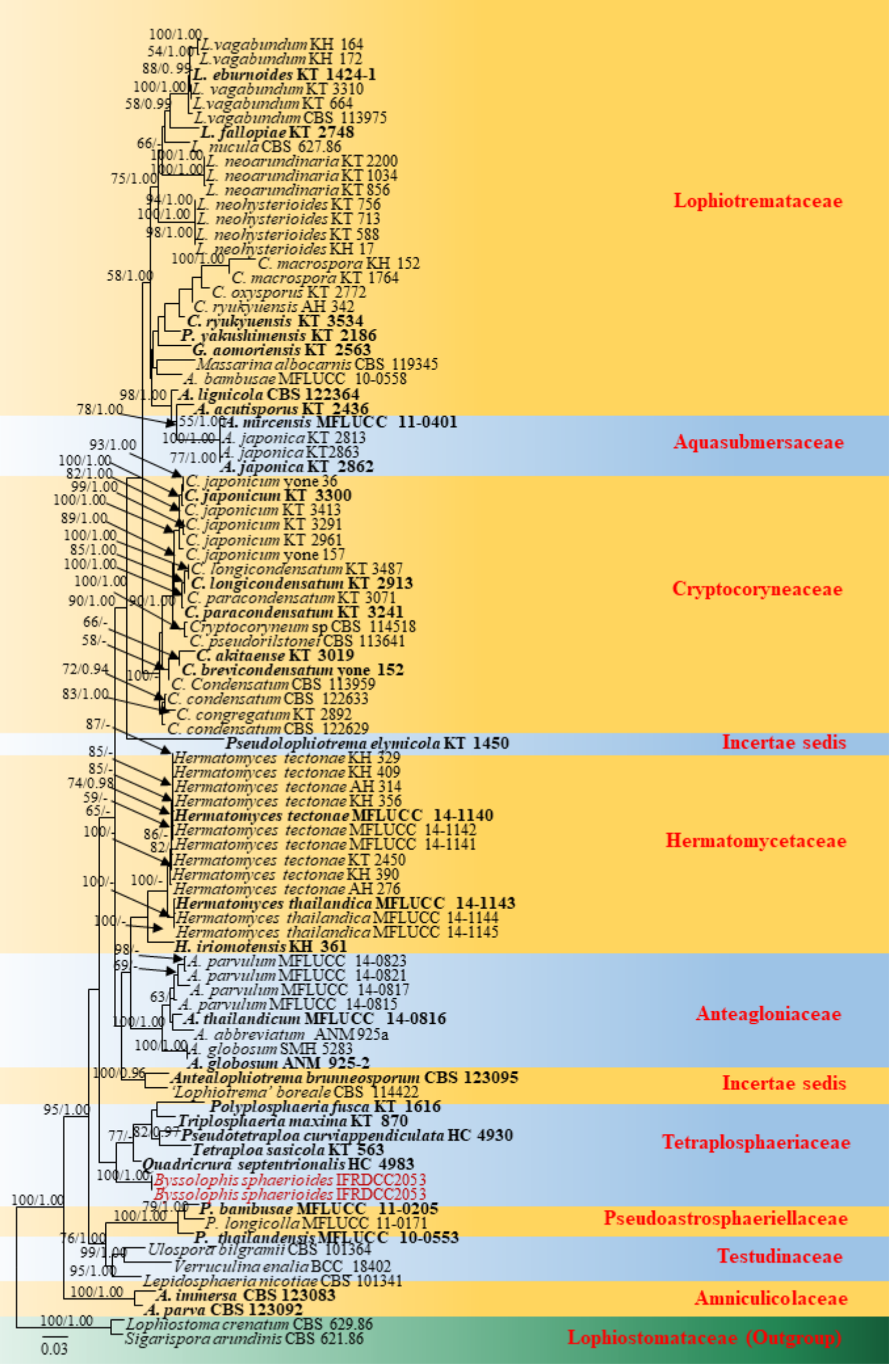


Figure 13 - Phylogram generated from maximum likelihood analysis based on combined LSU, SSU, TEF and RPB2 sequence data retrieved from the GenBank. Related sequences were referred to Hashimoto al. 2017). Eighty-nine taxa are included in the gene sequence analyses which comprise 3457 characters after alignment. Lophiostoma crenatum (CBS 629. 86) and Sigarispora arundinis (CBS 621. 86) are used as the out-group taxa. Maximum likelihood (ML) analysis was conducted in the CIPRES Science Gateway V. 3.3. The best sorting RAxML tree with a final likelihood value of -26435.927200 is presented. Estimated base frequencies were as follows: $\mathrm{A}=$ $0.247476, \mathrm{C}=0.248533, \mathrm{G}=0.272591, \mathrm{~T}=0.231400$; substitution rates $\mathrm{AC}=1.176163, \mathrm{AG}=$ 4.952466, $\mathrm{AT}=1.237377, \mathrm{CG}=1.159438, \mathrm{CT}=9.445473, \mathrm{GT}=1.000000$; gamma distribution shape parameter $\alpha=0.457069$; proportion of invariant 0.561533 . ML bootstrap values $\geq 50 \%$ are given as the first set of numbers and approximate likelihood-ratio test (aLRT) $\geq 0.90$ values as the second set of numbers above the nodes. Voucher/strain numbers are given after the taxon names, the one from type material are indicated in bold face. Sequence of interest is indicated in red. The bar length indicates the number of nucleotide substitutions per site.

Type species - Englerodothis kilimandscharica (Henn.) Theiss. \& Syd.

Notes - The genus Englerodothis was introduced by Theissen and Sydow (1915) for the type species Englerodothis kilimandscharica. The asexual morph is unknown. Currently, three species are accomodated in this genus. Englerodothis was placed in Parmulariaceae by many authors (Hofmann 2009, Lumbsch \& Huhndorf 2010). However, Hyde et al. (2013) excluded the genus Englerodothis from Parmulariaceae as Englerodothis had enclosed ascomata and only one ascomatal wall layer composed of cells of textura angularis (Inácio \& Cannon 2008). Cultures and sequences are unavailable. We studied the type specimen of Englerodothis kilimandscharica from S herbarium under the code F203689. Englerodothis kilimandscharica shares similar characters with the genus Coccoidea, such as circular or discoid ascostroma, multi-loculate, dark pigmented, bitunicate asci and 1-septate and light pigmented ascospores. Englerodothis is therefore tentatively placed in the family Coccoideaceae.

Englerodothis kilimandscharica (Henn.) Theiss. \& Syd., Annls mycol. 13(3/4): 285 (1915)

Fig. 16

三 Cocconia kilimandscharica Henn., in Engler, Pflanzenw. Ost-Afrikas Nachbarg., Teil C: 31 (1895)

Index Fungorum number: IF 150008; Facesoffungi number: FoF 06240

Biotrophic, pathogenic or saprobic on living and dead leaves of Mayepea gilgiana. Sexual morph: Stroma black, hard, subglobose to hemispherical, hypostromatic, multiloculate, strongly convoluted and forming an elaborate geometrical pattern externally, 7-8 $\mathrm{mm}$ in diam, the opposite upper surface of the leaf has sunken deeply in the extension of the stromata and has a dirty yellow discoloration, irregular in circumference, roundish, elongated or blister-shaped. Locules very numerous and dense, spherical. Individual stomatal elements up to 133-139 $\mu \mathrm{m}$ wide, 107-116 $\mu \mathrm{m}$ high, the tissues surrounding the locules made up of brown to dark brown pseudoparenchymatous tissue, lower region of base composed of small hyaline angular cells which tend to replace the cuticular lining of the leaf and penetrate between the distorted epidermal cells. Locules elongate the side wall, but merging with stromatal tissue, made up of dark brown angular cells with 1-2 paler inner layers, the apical part, flat, and dark brown, splitting at maturity to expose asci and interascal tissue. Interascal tissue of cellular pseudoparaphyses, copious, filamentous, each filament consisting of a chain of hyaline cells, the lower ones being compressed by the growing asci, the upper ones irregular in shape and reaching and becoming pigmented and surrounded by a copious gelatinous matrix. Asci 58-61 $\mu \mathrm{m} \times 11-19 \mu \mathrm{m}(\bar{x}=59.5 \times 16.7 \mu \mathrm{m}, \mathrm{n}=10)$, 8-spored, cylindrical to cylindric-clavate, the apex broadly rounded, the base tapering abruptly to a short stalk, fairly thick-walled at all stages, thickest at the apex, fissitunicate, without an apical ring. Ascospores 15$16 \mu \mathrm{m} \times 5-6 \mu \mathrm{m}(\bar{x}=16.3 \times 6.0 \mu \mathrm{m}, \mathrm{n}=10)$, arranged biseriately, 1-septate, slightly constricted at 
the septum, the upper cell with a rounded end, the lower one tapering, smooth and hyaline when young, pale brown at maturity. Asexual morph: Undetermined.

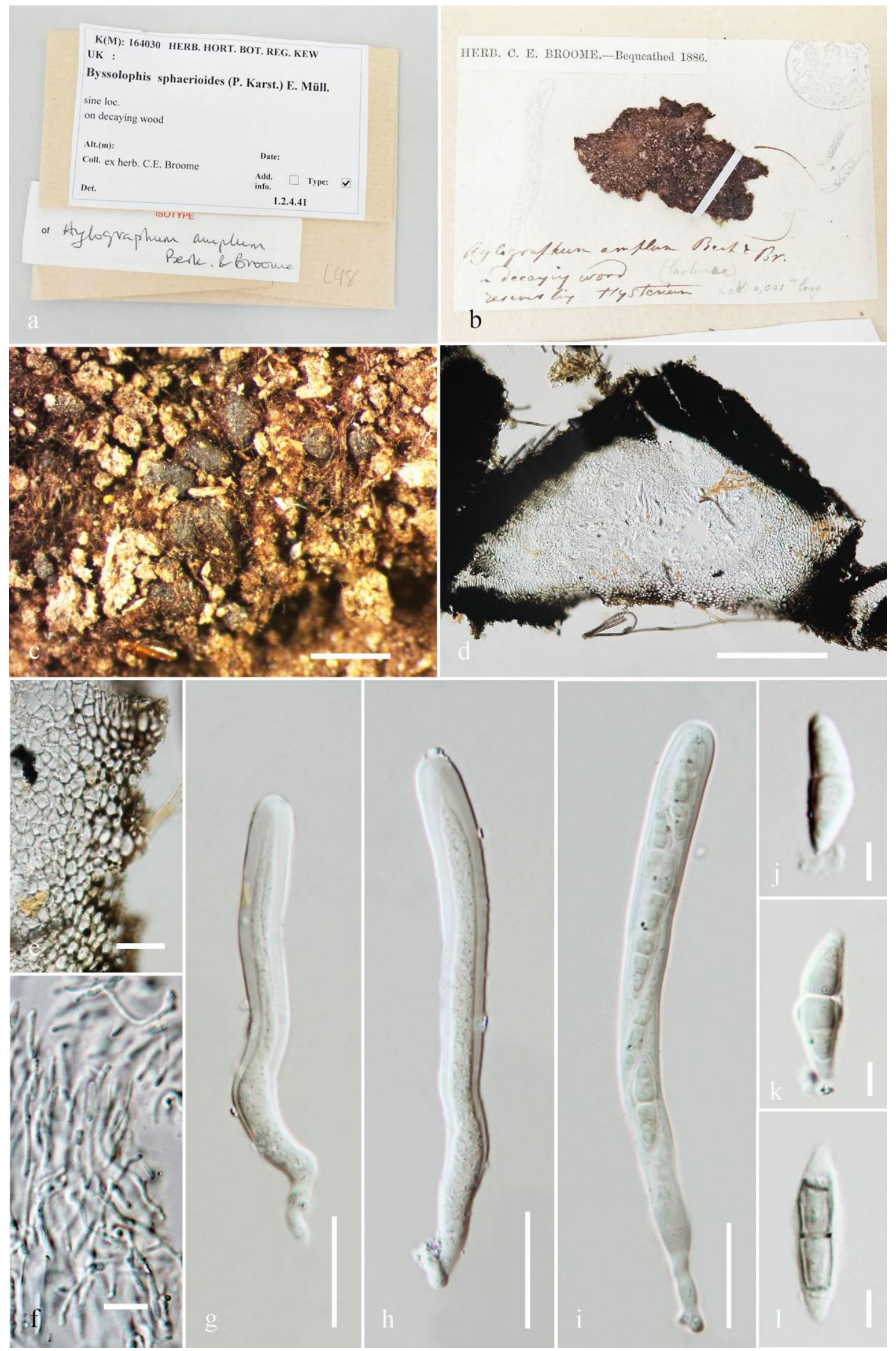

Figure 14 - Byssolophis sphaerioides (K (M) 164030, isotype). a-b Herbarium specimen and habit on leaf. c Appearance of ascomata on the host surface. d Section of ascoma. e Peridium. $f$ 
Hamathecium. g-i Asci. j-l Ascospores. Scale bars: $\mathrm{c}=500 \mu \mathrm{m}, \mathrm{d}=100 \mu \mathrm{m}, \mathrm{e}=50 \mu \mathrm{m}, \mathrm{f}=10 \mu \mathrm{m}$, $\mathrm{g}-\mathrm{i}=20 \mu \mathrm{m}, \mathrm{j}-\mathrm{l}=5 \mu \mathrm{m}$.

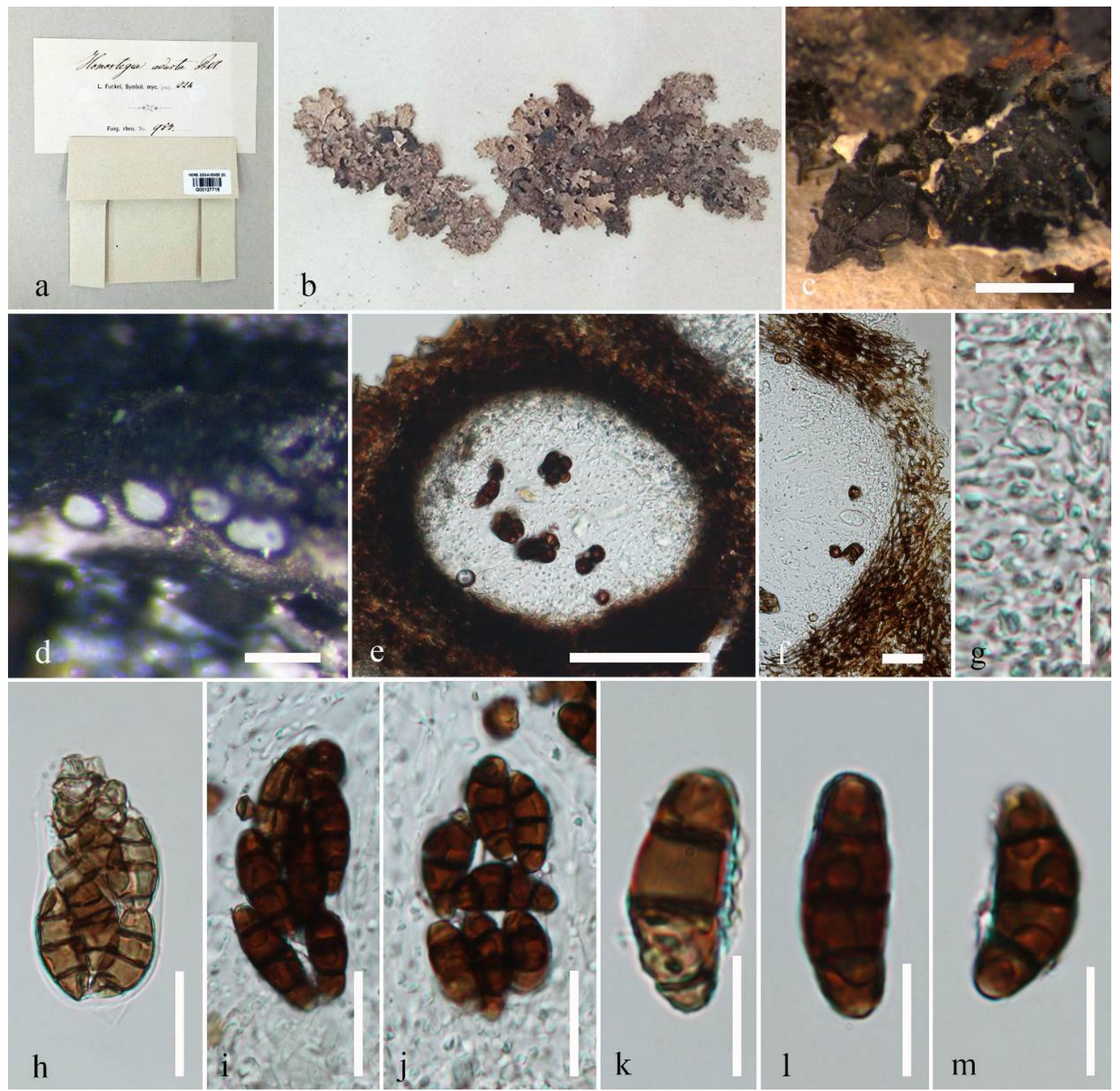

Figure 15 - Homostegia adusta (G-322312/1, holotype). a, b Details of herbarium material. c Habit and appearance of ascomata on host surface. $d$ Locules within ascostromata. e Section of ascoma. $\mathrm{f}$ Peridium. g Hamathecium. h-j Asci. k-m Ascospores. Scale bars: $\mathrm{c}=1 \mathrm{~mm}, \mathrm{~d}=200 \mu \mathrm{m}$, e $=30$ $\mu \mathrm{m}, \mathrm{f}, \mathrm{h}-\mathrm{j}=20 \mu \mathrm{m}, \mathrm{g}, \mathrm{k}-\mathrm{m}=10 \mu \mathrm{m}$.

Material examined - AFRICA, Tanzania, Boma La Ng’ombe, Kilimanjaro, on living and dead leaves of Mayepea gilgiana (Oleaceae), 8 December 1893, G. Volkens, (S-F203689, holotype).

Economic significance - The genus Englerodothis is parasitic on living leaf blades petioles, and inflorescences and affect many hosts namely Mayepea gilgiana (Oleaceae) by air-borne ascospores. They are mainly reported from Africa, South of Sahara, Tanzania (Inacio \& Minter 2000).

Dubujianaceae D. Pem, Doilom \& K.D. Hyde, fam. nov.

Index Fungorum number: IF557065; Facesoffungi number: FoF 06679

Endophytic, saprobic or pathogenic on leaves. Sexual morph: Undetermined. Asexual morph: Mycelium at first subcuticular, developing onto leaf surface from leaf glands forming scattered to 
sporadically confluent superficial thalli, circular in outline, composed of a basal layer of flattened, parallel, branching, brown hyphae with setae. Non-hyphopodiate hyphal strands radiate from base of central, raised pycnidium over the basal layer and onto the substrate. Conidiomata wall composed of thick dark-brown walled cells of textura globulosa. Conidiophores densely aggregated, slender, subulate, simple, frequently branched above, reduced to conidiogenous cells, or with 1-2 supporting cells. Conidiogenous cells annellidic, simple, tapering, hyaline, smooth, rarely with percurrent proliferations. Conidia ellipsoidal, fusiform to lunate, hyaline becoming pale brown at maturity, 1-septare, punctate, non-constricted, smooth-walled.

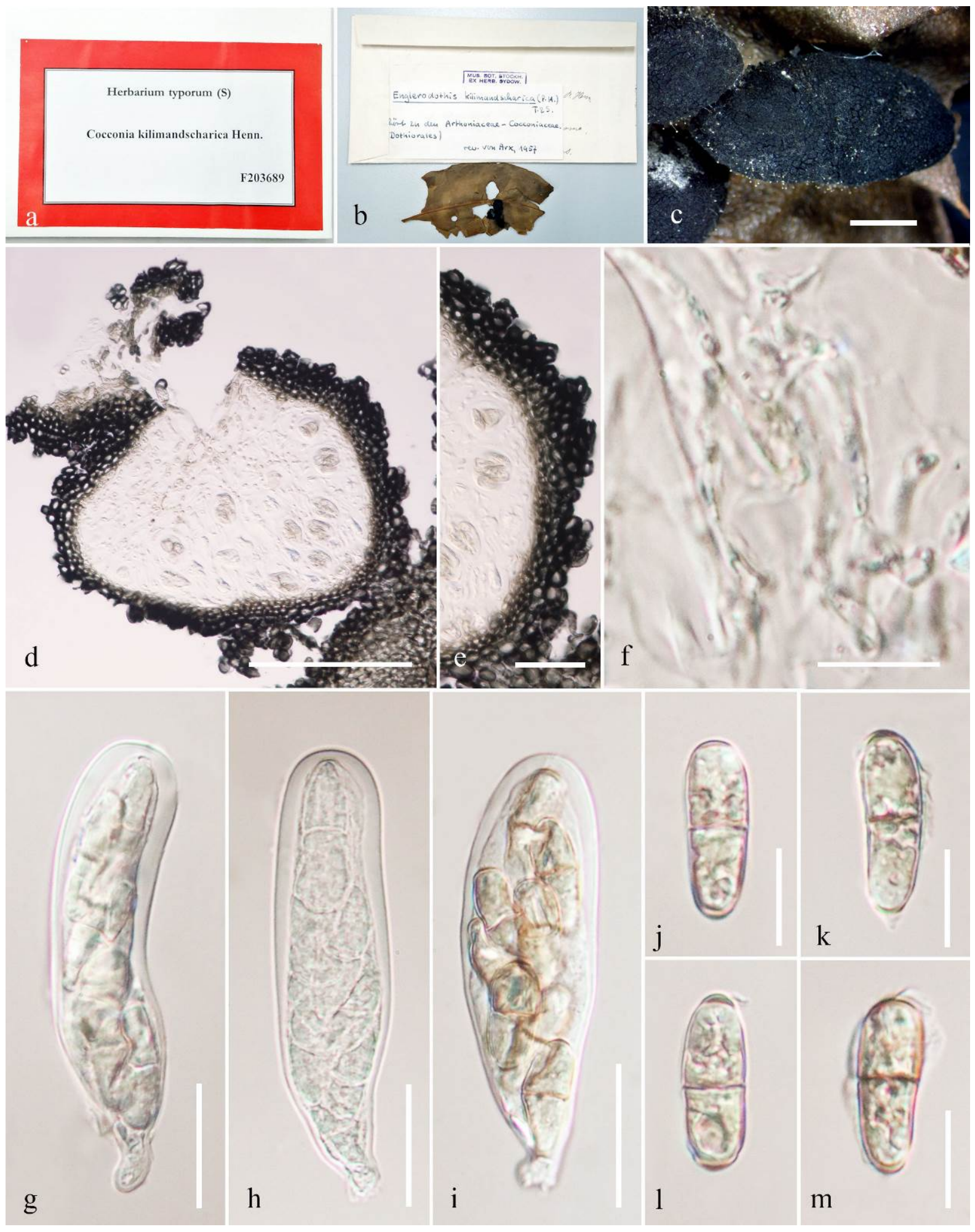


Figure 16 - Englerodothis kilimandscharica (S-F203689, holotype). a Details of herbarium material. b, c Habit and appearance of ascomata on host surface. d Section of ascoma. e Peridium. $f$ Hamathecium. g-i Asci. j-m Ascospores. Scale bars: $c=2 \mathrm{~mm}, \mathrm{~d}=30 \mu \mathrm{m}, \mathrm{e}, \mathrm{f}, \mathrm{j}-\mathrm{m}=10 \mu \mathrm{m}, \mathrm{g}-\mathrm{i}$ $=20 \mu \mathrm{m}$.

Family type - Dubujiana D.R. Reynolds \& G.S. Gilbert

Notes - The family Dubujianaceae is introduced to accommodate the monotypic genus Dubujiana based on its epifoliar lifestyle and unique pycnidia that arise from leaf glands in the outer portions of the hyphal system with individual hyphal strands extending from the large central pycnidium. We introduce the new family Dubujianaceae, because it has a set of unique characters namely ahyphopodiate pycnidia, conidiomata wall composed of dark-brown walled cells of textura globulosa and 1-septate, punctate hyaline to pale brown conidia that differ from other families of Dothideomycetes.

Dubujiana D.R. Reynolds \& G.S. Gilbert, Aust. Syst. Bot. 18(3): 282 (2005)

Endophytic, saprobic or pathogenic on leaves. Sexual morph: Undetermined. Asexual morph: Mycelium at first subcuticular, developing onto leaf surface from leaf glands forming scattered to sporadically confluent superficial thalli, circular in outline, composed of a basal layer of flattened, parallel, branching, brown hyphae brown hyphae with setae. Non-hyphopodiate hyphal strands radiate from base of central, raised pycnidium over the basal layer and onto the substrate. Conidiomata wall composed of thick dark-brown walled cells of textura globulosa. Conidiophores densely aggregated, slender, subulate, simple, frequently branched above, reduced to conidiogenous cells, or with 1-2 supporting cells. Conidiogenous cells annellidic, simple, tapering, hyaline, smooth, with percurrent proliferations. Conidia ellipsoidal, fusiform to lunate, hyaline becoming pale brown at maturity, 1-septare, punctate, non-constricted, smooth-walled.

Type species - Dubujiana glandulifera D.R. Reynolds \& G.S. Gilbert

Notes - During a study of epifoliar ascomycetes from leaf surfaces in the forests of Queensland Australia, Reynolds \& Gilbert (2005) reported the monotypic genus Dubujiana, with Dubujiana glandulifera as the type species, but did not assign the genus to any family. The genus Dubujiana is characterized by raised pycnidium over the basal layer of the substrate, densely aggregated, slender conidiophores, and tapering, hyaline conidiogenous cells giving rise to pale brown, 1-septate punctate conidia. Cultures and sequences are unavailable. The genus Dubujiana resembles species of Asterinaceae and Microthyriaceae in having superficial hyphae, radiating from base of central layer on the substrate. However, it is distinct in having a pycnidial wall which consists of cells of textura globulosa and 1-septate, punctate, non-constricted conidia. We therefore, accommodate the genus Dubujiana in a new family Dubujianaceae based on its epifoliar lifestyle and unique morphological characters.

Dubujiana glandulifera D.R. Reynolds \& G.S. Gilbert, Aust. Syst. Bot. 18(3): 282 (2005)

Index Fungorum number: IF344434; Facesoffungi number: FoF 06238

Fig. 17

Endophytic, pathogenic or saprobic on leaves. Sexual morph: Undetermined. Asexual morph: Mycelium at first subcuticular, developing onto leaf surface from leaf glands forming scattered to sporadically confluent superficial thalli, circular in outline, composed of a basal layer of flattened, parallel, branching, brown hyphae. Pycnidium 181-290 $\mu \mathrm{m} \times 195-270 \mu \mathrm{m}(\bar{x}=225.1 \times 250.1 \mu \mathrm{m}$, $\mathrm{n}=10$ ), individual, non-hyphopodiate hyphal strands radiating from base of central, raised over the basal layer and onto the substrate. Conidiomata wall 12-27 $\mu \mathrm{m}$ composed of thick dark-brown walled cells of textura globulosa. Conidiophores densely aggregated, slender, subulate, simple, frequently branched above, reduced to conidiogenous cells, or with 1-2 supporting cells. Conidiogenous cells annellidic, simple, tapering, hyaline, smooth, rarely with percurrent proliferation. Conidia 5-9 $\mu \mathrm{m} \times 2-3 \mu \mathrm{m}(\bar{x}=7.6 \times 2.7 \mu \mathrm{m}, \mathrm{n}=10)$, ellipsoidal, fusiform to lunate, 
aseptate, hyaline becoming pale brown at maturity, smooth, 1- septate, punctate, non-constricted, smooth-walled.

Material examined - AUSTRALIA, Queensland, Cape Tribulation Coastal Boardwalk Dubuji, $145^{\circ} 28^{\prime}$ E, $16^{\circ} 4^{\prime}$ 'S., on leaves, 2 February 2002, Don R. Reynolds (UC AUS399, holotype).

Economic significance -Species of the genus Dubujiana are epifoliar fungi and maintain a commensal relationship with the host (Reynolds \& Gilbert 2005). They may interrupt light or act synergistically or antagonistically with pathogens and effect on disease development (Dasari 2012).

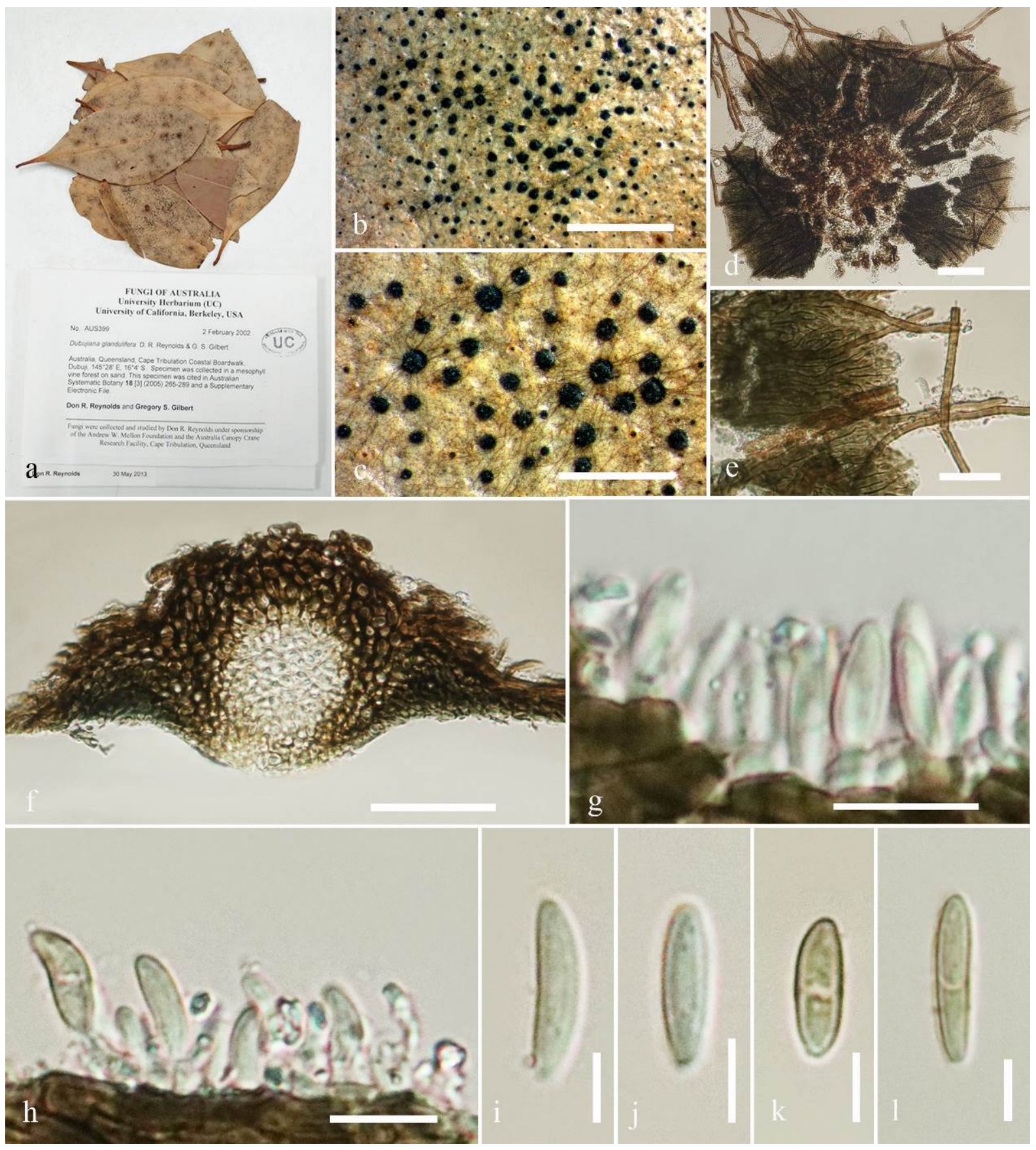

Figure 17 - Dubujiana glandulifera (UC AUS399, holotype). a Details of herbarium material. b, c Habit and appearance of conidiomata on host surface. d Squash mount of conidioma. e Dual hyphal system showing small pycnidia in the outer portions with inidividual hyphal strands extending from a large central pycnidium. $\mathrm{f}$ Section of conidioma $\mathrm{g}$, $\mathrm{h}$ Conidiogenesis. $\mathrm{i}-\mathrm{l}$ Conidia. Scale bars: $\mathrm{b}=$ $2 \mathrm{~mm}, \mathrm{c}=1 \mathrm{~mm}, \mathrm{~d}, \mathrm{e}=20 \mu \mathrm{m}, \mathrm{f}=40 \mu \mathrm{m}, \mathrm{g}=100 \mu \mathrm{m}, \mathrm{h}=10 \mu \mathrm{m}, \mathrm{i}-\mathrm{l}=5 \mu \mathrm{m}$. 
Endosporiaceae D. Pem, Doilom \& K.D. Hyde, fam. nov.

Index Fungorum number: IF557066; Facesoffungi number: FoF 06681

Pathogenic on bud of Populus tremuloides. Sexual morph: Undetermined. Asexual morph: Colonies (conidiomata) on PDA, OA and CA black, raised, cerebriform, comprising numerous cellular clumps in a thin glop covering, subcircular to irregular in outline, reverse black. Margin irregular with scarce, occasionally aggregated hyphae on PDA, even with adpressed or submerged hyphae on MEA. On PDA, cells more broad, swollen, subhyaline and dumbbell-shaped when twocelled, becoming multicellular by splitting in all directions, turning darkly pigmented, irregular in shape, frequently separating into smaller clumps. Hyphae cylindric-shaped or toruloid, light to dark brown, branched or unbranched, aerial ones determinate in growth, mostly elongated, hyaline at apex, forming muriform and darkly pigmented bodies. Endoconidia developing from the separation of adjacent daughter cells in cellular clumps through septum schizolysis, unicellular, hyaline, ellipsoidal to subglobose turning broadly ellipsoidal to globose. Blastic conidia abundant in mature colonies, arising from cells of cellular clumps or seldom from sides of hyphae, unicellular, hyaline or light brown, cylindrical to ellipsoidal, regularly truncate at the base, sometimes globose, obovoid, fusiform.

Family type - Endosporium Tsuneda

Notes - The family Endosporiaceae is introduced to accommodate the genus Endosporium typified by E. populi-tremuloides. Endosporiaceae is characterized by cylindric-shaped hyphae, ellipsoidal, subglobose to globose endoconida and cellular clumps, globose, obovoid, fusiform blastic conidia. The family Endosporiaceae is distinct from other families in the Dothideomycetes in having endoconidia forming as cellular clumps through septum schizolysis and blastic hyaline or light brown conidia. Further studies may aim to link asexual morphs of species in this family to their sexual counterparts.

Endosporium Tsuneda, in Tsuneda, Davey, Hambleton \& Currah, Botany 86(9): 1022 (2008)

Pathogenic on bud of Populus tremuloides. Sexual morph: Undetermined. Asexual morph: Colonies (conidiomata) on PDA, OA and CA black, raised, cerebriform, comprising numerous cellular clumps in a thin glop covering, subcircular to irregular in outline, reverse black. Margin irregular with scarce, occasionally aggregated hyphae on PDA, even with adpressed or submerged hyphae on MEA. Conidiogenous cells on PDA, more broad, swollen, subhyaline and dumbbellshaped when two-celled, becoming multicellular by splitting in all directions, turning darkly pigmented, irregular in shape, frequently separating into smaller clumps. Hyphae cylindric-shaped or toruloid, light to dark brown, branched or unbranched, aerial ones determinate in growth, mostly elongated, hyaline at apex, forming muriform and darkly pigmented bodies. Endoconidia developing from the separation of adjacent daughter cells in cellular clumps through septum schizolysis, unicellular, hyaline, ellipsoidal to subglobose turning broadly ellipsoidal to globose. Blastic conidia abundant in mature colonies, arising from cells of cellular clumps or seldom from sides of hyphae, unicellular, hyaline or light brown, cylindrical to ellipsoidal, regularly truncate at the base, sometimes globose, obovoid, fusiform.

Type species - Endosporium populi-tremuloides Tsuneda

Notes - The hyphomycetous genus Endosporium was the first genus with endoconidial and black meristematic cells reported in the order Myriangiales by A. Tsuneda. The genus Endosporium is characterized by subhyaline and dumbbell-shaped cells forming ellipsoidal to globose hyaline endoconidia and hyaline or light brown, cylindrical to ellipsoidal blastic conidia. Two species namely, Endosporium populi-tremuloides Tsuneda and E. aviarium Tsuneda are accommodated in the genus Endosporium. Endosporium populi-tremuloides is the type species of the genus and was found on the bud of Populus tremuloides. Cultures and sequences are available. Phylogenetic analyses using LSU, SSU and ITS sequences from GenBank strongly support placement of the genus Endosporium as an independent lineage (Fig. 18). It is not clear whether Endosporium should be in Myriangiales or not. The genus Endosporium is distinct from all species 
in the Dothideomycetes and is accommodated in a new family Endosporiaceae, order incertae sedis.

Endosporium populi-tremuloides Tsuneda, in Tsuneda, Davey, Hambleton \& Currah, Botany 86(9): 1023 (2008)

Fig. 19

Index Fungorum number: IF536901; Facesoffungi number: FoF 06239

Pathogenic on bud of Populus tremuloides. Sexual morph: Undetermined. Asexual morph: Colonies (conidiomata) on PDA, OA and CA black, raised, cerebriform, comprising numerous cellular clumps in a thin glop covering, subcircular to irregular in outline, reverse black. Margin irregular with scarce, occasionally aggregated hyphae on PDA, even with appressed or submerged hyphae on MEA. On PDA, conidiogeneous cells 6-15 $\mu \mathrm{m} \times 8-20 \mu \mathrm{m}(\bar{x}=11.5 \times 19.8 \mu \mathrm{m}, \mathrm{n}=$ 10 ), broad, subhyaline and dumbbell-shaped when two-celled, later splitting by septations in all directions, turning darkly pigmented, irregular in shape, frequently separating into smaller clumps. Hyphae $65 \mu \mathrm{m}$ long, 3-6 $\mu \mathrm{m}$ wide cylindric-shaped or torulose, light to dark brown, branched or unbranched, aerial ones determinate in growth, mostly elongated, hyaline at the apex, forming muriform and darkly pigmented bodies. Endoconidia $2.5-5 \mu \mathrm{m} \times 1-3 \mu \mathrm{m}(\bar{x}=3.5 \times 2.8 \mu \mathrm{m}, \mathrm{n}=$ 10), developing from the separation of adjacent daughter cells in cellular clumps through schizolytic septum, unicellular, hyaline, ellipsoidal to subglobose turning broadly ellipsoidal to globose. Blastic conidia 2.5-14.5 $\mu \mathrm{m} \times 1-4.5 \mu \mathrm{m}(\bar{x}=3.5 \times 2.8 \mu \mathrm{m}, \mathrm{n}=10)$, abundant in mature colonies, arising from cells of cellular clumps or rarely from sides of hyphae, unicellular, hyaline or light brown, cylindrical to ellipsoidal, regularly truncate at the base, sometimes ovoid.

Material examined - CANADA, Whitemud Creek, Edmonton, Lansdowne, ca. $1 \mathrm{~km}$ west of the Northern Forestry Centre, Alberta, on bud of Populus tremuloides (Salicaceae), 3 November 2002, A. Tsuneda (UAMH 10529, holotype).

Economic significance - Species of the genus Endosporium are phytopathogenic fungi that cause scab, anthracnose, and leaf spot diseases on woody plants, as well as species of Salicaceae (Taylor et al. 2001, Butin \& Kehr 2004). The genus Endosporium can also cause mycotic diseases in humans due to their meristematic growth (Tsuneda et al. 2008).

Macrovalsariaceae D. Pem, Doilom \& K.D Hyde, fam. nov.

Index Fungorum number: IF557067; Facesoffungi number: FoF 06682

Saprobic on dead twigs, wood, bamboo and culms of a wide range of hosts. Sexual morph: Ascostromata dark brown to black, immersed to erumpent, solitary to a few in a group, carbonaceous, oblate, sphaeroid to subsphaerical, with a central ostiole. Peridium comprising brown and small-celled textura angularis. Asci 8-spored, bitunicate, fissitunicate, cylindro-clavate, with a short fine pedicel, apically rounded with a small ocular chamber. Paraphyses unbranched, tapering upwards, apically free. Ascospores uniseriate to irregularly uniseriate, 1- septate, brown, elliptical-fusoid, slightly constricted at septum, with skull cap-like germ apparatus at the lower end, transverse striation near the center of lower cell with longitudinal striations from transverse striation to the end cell surface smooth, granular to verrucose. Asexual morph: Undetermined.

Family type - Macrovalsaria Petr.

Notes - The family Macrovalsariaceae is introduced to accommodate the monotypic genus Macrovalsaria typified by $M$. leonensis. Macrovalsariaceae has dark brown to black ascostromata, cylindro-clavate asci, with a short fine pedicel and elliptical to fusoid ascospores with skull cap-like germ apparatus. Phylogenetically, Macrovalsaria clustered in a strongly supported clade among the families in the order Pleosporales. The family Macrovalsariaceae shares some similar characters of ascostromata and asci with Valsariaceae. However, Macrovalsariaceae differs from Valsariaceae by its ascospores features.

Macrovalsaria Petr., Sydowia 15(1-6): 298 (1962) [1961]

Saprobic on dead twigs, wood, bamboo and culms of a wide range of hosts. Sexual morph: Ascostromata dark brown to black, immersed to erumpent, solitary to a few in a group, 
carbonaceous, oblate, sphaeroid to subsphaerical, with a central ostiole. Peridium comprising brown and small-celled textura angularis. Asci 8-spored, bitunicate, fissitunicate, cylindro-clavate, with a short fine pedicel, apically rounded with a small ocular chamber. Paraphyses unbranched, tapering upwards, apically free. Ascospores uniseriate to irregularly uniseriate, 1- septate, brown, elliptical-fusoid, slightly constricted at septum, with skull cap-like germ apparatus at the lower end, transverse striation near the center of lower cell with longitudinal striations from transverse striation to the end cell, surface smooth, granular to verrucose. Asexual morph: Undetermined.

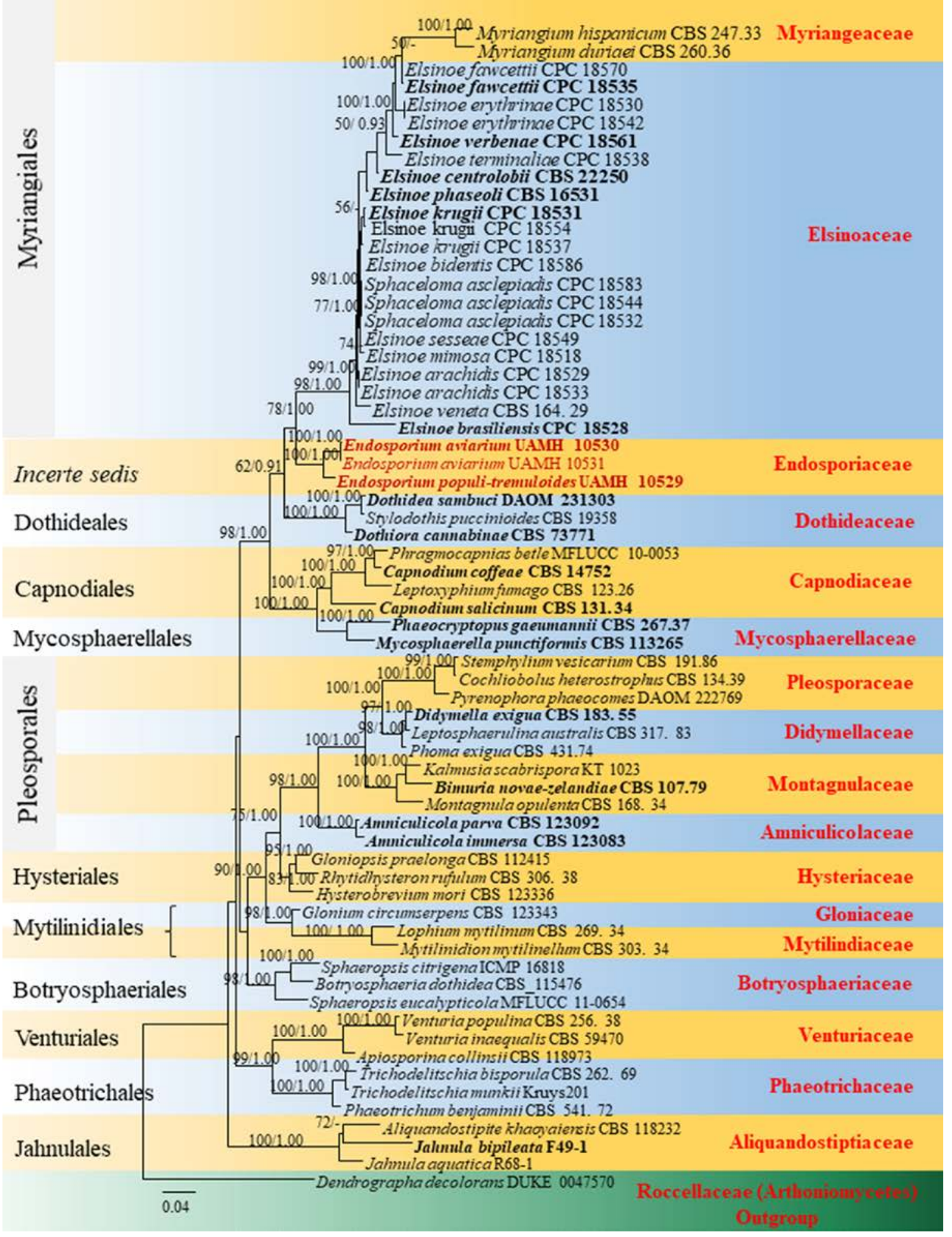


Figure 18 - Phylogram generated from maximum likelihood analysis based on combined LSU SSU and ITS sequence data retrieved from the GenBank. Related sequences were referred to Tsuneda et al. 2008 and Jayawardene et al. 2014). Sixty-five taxa are included in the genes sequence analyses which comprise total 2581 characters after alignment. Dendographa decolorans (DUKE 0047570) is used as the out-group taxon. Maximum likelihood (ML) analysis was conducted in the CIPRES Science Gateway V. 3.3. The best sorting RAxML tree with a final likelihood value of -20117.489107 is presented. Estimated base frequencies were as follows: $\mathrm{A}=$ $0.255618, \mathrm{C}=0.221836, \mathrm{G}=0.277683, \mathrm{~T}=0.244863$; substitution rates $\mathrm{AC}=1.219900, \mathrm{AG}=$ 2.441823, $\mathrm{AT}=1.343822, \mathrm{CG}=1.136438, \mathrm{CT}=6.322671, \mathrm{GT}=1.000000$; gamma distribution shape parameter $\alpha=0.470888$; proportion of invariant 0.356870 . ML bootstrap values $\geq 50 \%$ are given as the first set of numbers and approximate likelihood-ratio test (aLRT) $\geq 0.90$ values as the second set of numbers above the nodes. Voucher/strain numbers are given after the taxon names, the one from type material are indicated in bold face. Sequence of interest is indicated in red. The bar length indicates the number of nucleotide substitutions per site.

Type species - Macrovalsaria leonensis (Deighton) Petr. 1962

Notes - Petrak \& Deighton (1962) introduced the genus Macrovalsaria with M. leonensis (三 Valsaria leonensis Deighton, in Petrak \& Deighton 1952) as the type species. The genus Macrovalsaria has a global distribution in the tropics. Sivanesan (1975) examined the type specimen of $M$. megalospora (三 Sphaeria megalospora Mont.) and several other specimens including $M$. leonensis (Deighton) Petr. (the generic type), and synonymised all of them under Macrovalsaria megalospora which is the primogenital epithet. The unique characteristic of the genus Macrovalsaria is the brown, uniseptate ascospores that are constricted at the septum and the skull cap-like germ apparatus at the base (Sivanesan 1975, Hyde et al. 2000). The asexual morph is unknown. Phylogenetic analysis carried out by Li \& Zhuang (2009) based on 28S rDNA showed that the genus Macrovalsaria is related to Botryosphaeriales and in their analysis, two strains of $M$. megalospora clustered in the Lasiodiplodia. Cultures and sequences are available but not for the type species. In another study, Doilom et al. (2017) described Macrovalsaria megalospora from Tectona grandis in northern Thailand, provided voucher specimens and placed their voucher specimens to Dothideomycetes incertae sedis based on morphology and phylogenetic analysis. We re-studied the specimen of Macrovalsaria leonensis from PDD collected by Deighton under the code PDD 14987. The ascospores illustrated are re-drawn from Chacón et al. (2014) to show the diagnostic characters of the ellipsoidal ascospores namely, the helmet-like cover with striae toward one end and the occurrence of single septum. We carried out phylogenetic analysis with the strains provided by Li \& Zhuang (2009) as well as those of Doilom et al. (2017). The strains of $M$. megalospora provided by Li \& Zhuang (2009) clustered in the Lasiodiplodia which is inconclusive as the analysis was based only on 28S large ribosomal subunit RNA gene regions. In depth analysis using TEF (data not shown) and ITS sequences of the reference specimen of M. megalospora provided by Doilom et al. (2017) shows that M. megalospora forms an independent lineage close to Valsariaceae and closely related families in the Dothideomycetes (Fig. 20) in the order Pleosporales. The new family Macrovalsariaceae is introduced to accommodate the monotypic genus Macrovalsaria typified by $M$. leonensis. Macrovalsariaceae has dark brown to black ascostromata, cylindro-clavate with a short fine pedicel asci and elliptical to fusoid with skull caplike germ apparatus at the lower end ascospores.

Macrovalsaria leonensis (Deighton) Petr., Sydowia 15(1-6): 298 (1962) [1961]

Fig. 21

$\equiv$ Valsaria leonensis Deighton, Sydowia 6(5-6): 321 (1952)

Index Fungorum number: IF 333867; Facesoffungi number: FoF 06251

Current name: Macrovalsaria megalospora (Mont.) Sivan. Trans. Br. Mycol. Soc. 65: 400 (1975)

Saprobic on dead branches of Caesalpinia sappan L. Sexual morph: Ascostromata 635-1010 $\mu \mathrm{m}$ high $\times$ 882-1015 $\mu \mathrm{m}$ diam., dark brown to black, immersed to erumpent, solitary to a few in a 
group, carbonaceous, oblate, spheroid to subsphaerical, with a central ostiole. Peridium comprising brown and small-celled textura angularis. Asci 192-198 × 31-41 $\mu \mathrm{m}(\bar{x}=195.9 \times 36.1, \mathrm{n}=20)$, 8spored, bitunicate, fissitunicate, cylindro-clavate, with a short fine pedicel, apically rounded with a small ocular chamber. Paraphyses 3-6 $\mu \mathrm{m}$ wide, unbranched, tapering upwards, apically free. Ascospores 38-40 $\mu \mathrm{m} \times 14-18 \mu \mathrm{m}(\bar{x}=38.8 \times 16.6 \mu \mathrm{m}, \mathrm{n}=20)$, uniseriate to irregularly uniseriate, 1-septate, brown, elliptical-fusoid, slightly constricted at septum, with skull cap-like germ apparatus at the lower end, transverse striation near the center of lower cell with longitudinal striations from transverse striation to the end cell, surface smooth, granular to verrucose. Asexual morph: Undetermined.

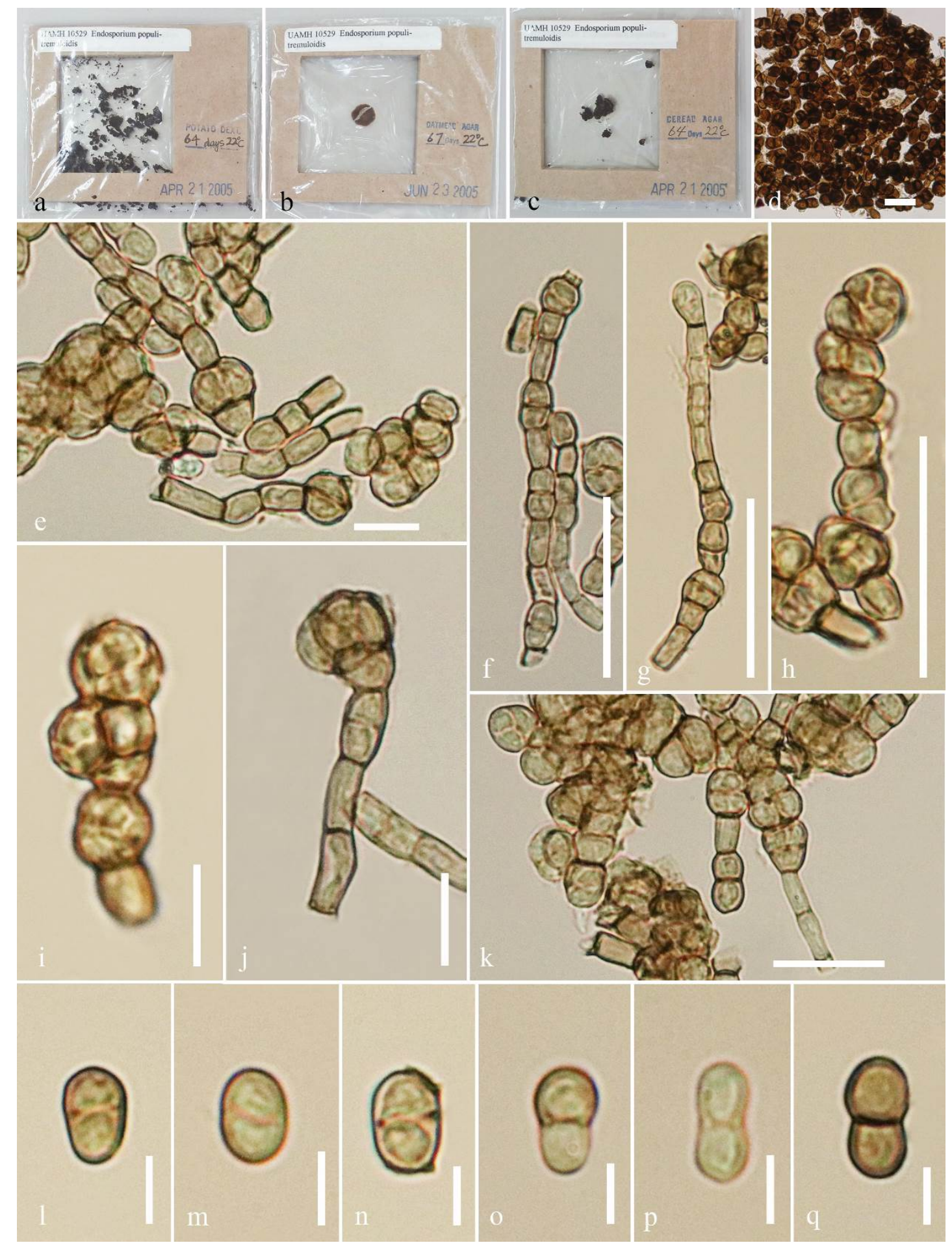

Figure 19 - Endosporium populi-tremuloides (UAMH 10529, holotype). a-c Details of herbarium material. d Squash mount of mycelium. e-k Hyphae giving rise to cellular clumps. i, j Cellular 
clumps and unicellular endoconidia. $\mathrm{l}-\mathrm{q}$ Blastic conidia. Scale bars: $\mathrm{d}, \mathrm{e}=20 \mu \mathrm{m}, \mathrm{f}-\mathrm{h}=30 \mu \mathrm{m}, \mathrm{i}-\mathrm{k}$ $=10 \mu \mathrm{m}, \mathrm{l}-\mathrm{q}=5 \mu \mathrm{m}$.

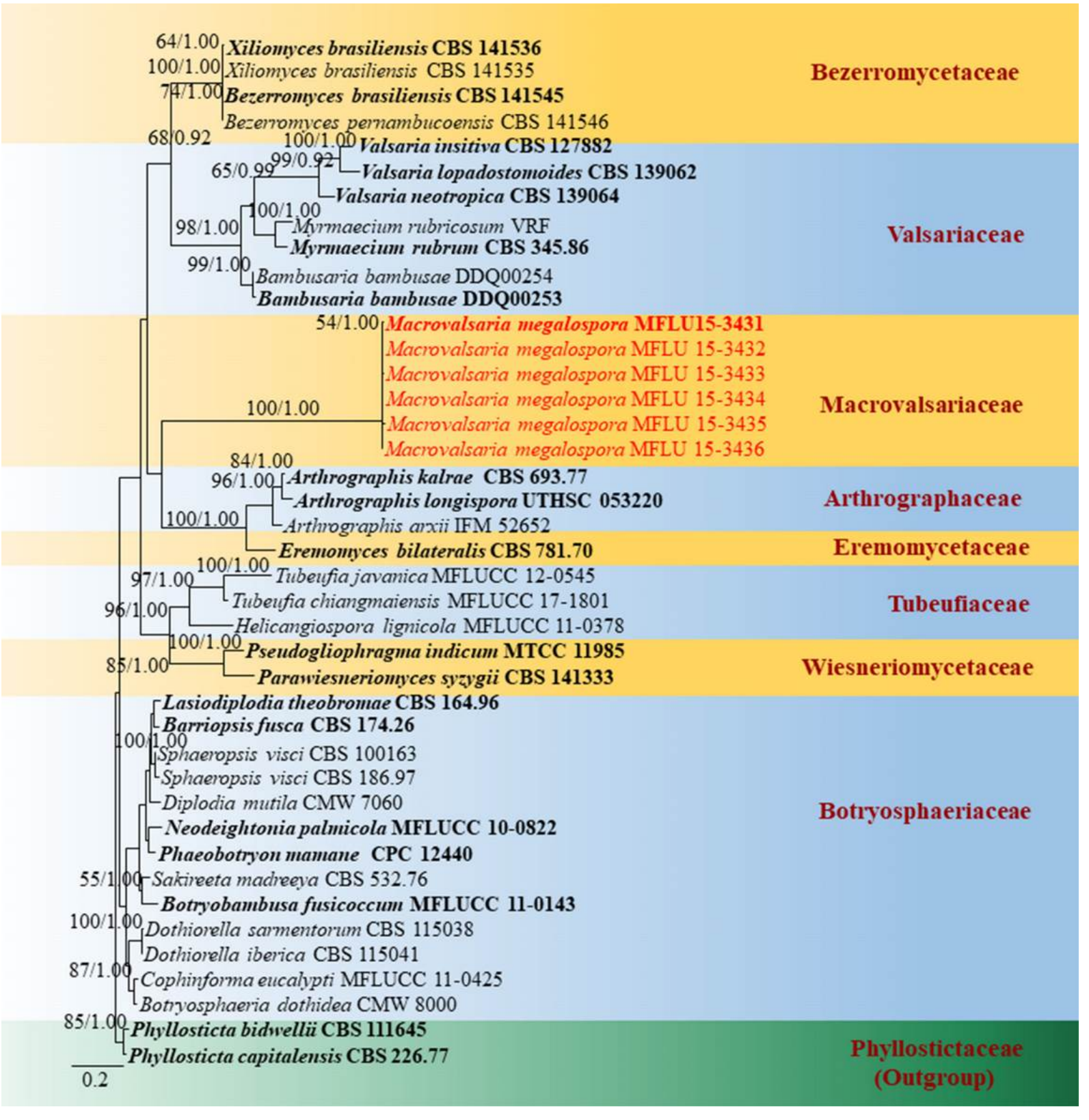

Figure 20 - Phylogram generated from maximum likelihood analysis based on ITS sequence data retrieved from the GenBank. Related sequences were referred to Liu et al. (2017) and Doilom et al. (2017). Forty-one taxa are included in the genes sequence analyses which comprise total 722 characters after alignment. Endomelanconiopsis endophytica (CBS 120397) and Endomelanconiopsis microspora (CBS 353.97) are used as the out-group taxa. Maximum likelihood (ML) analysis was conducted in the CIPRES Science Gateway V. 3.3. The best sorting RaXML tree with a final likelihood value of -7272.381820 is presented. Estimated base frequencies were as follows: $\mathrm{A}=0.216346, \mathrm{C}=0.295906, \mathrm{G}=0.263865, \mathrm{~T}=0.223882$; substitution rates AC $=1.268131, \mathrm{AG}=2.046492, \mathrm{AT}=1.609300, \mathrm{CG}=1.315693, \mathrm{CT}=3.295166, \mathrm{GT}=1.000000$; gamma distribution shape parameter $\alpha=1.183469$; proportion of invariant 0.261792 . ML bootstrap values $\geq 50 \%$ are given as the first set of numbers and approximate likelihood-ratio test (aLRT) $\geq$ 0.90 values as the second set of numbers above the nodes. Voucher/strain numbers are given after the taxon names, the one from type material are indicated in bold face. Sequence of interest is indicated in red. The bar length indicates the number of nucleotide substitutions per site. 


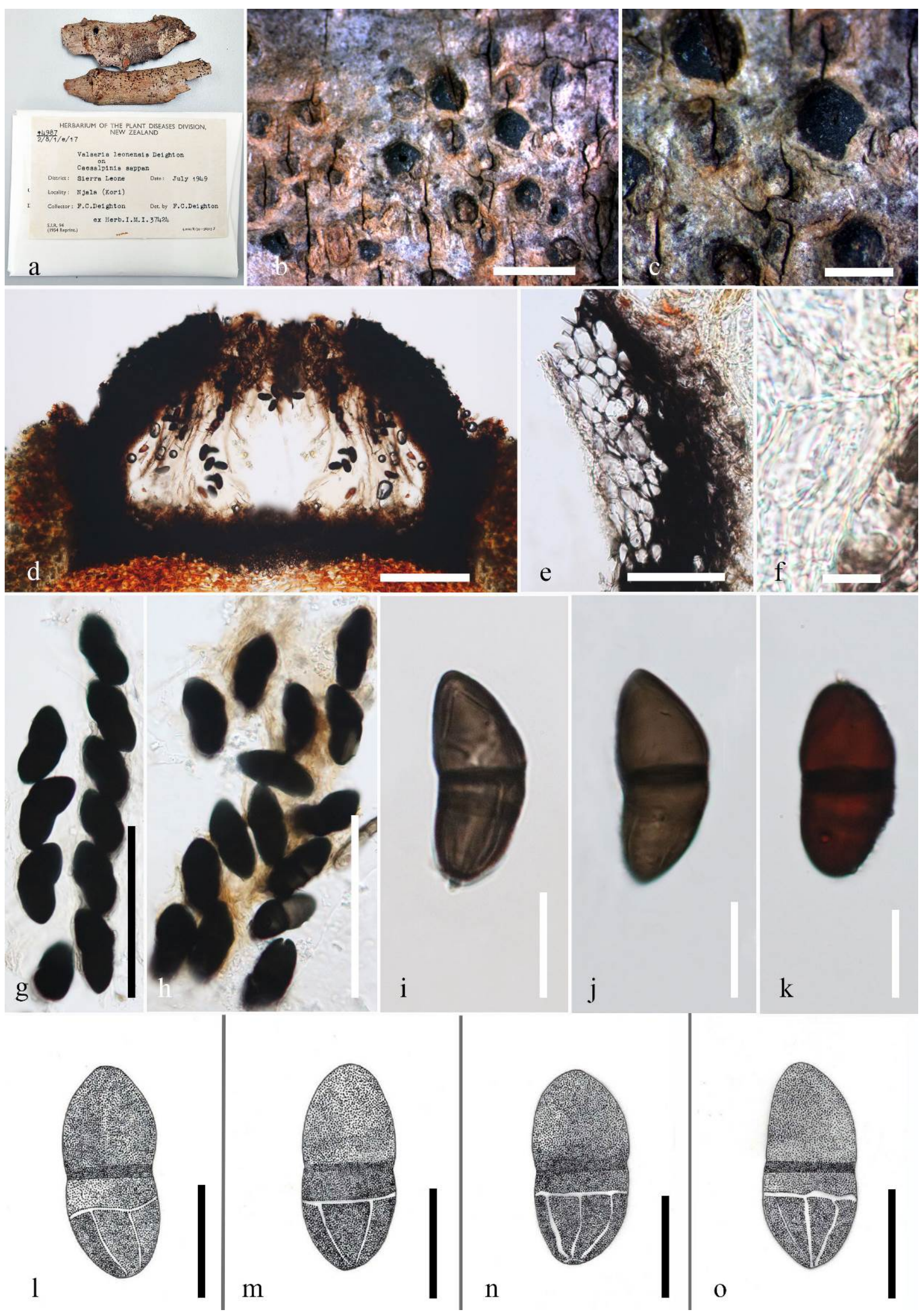

Figure 21 - Macrovalsaria leonensis (PDD 14987, co-extype). a Details of herbarium material. b, c Habit and appearance of ascomata on host surface. d Section of ascoma. e Peridium. $f$ Hamathecium g, h. Asci. i-o Ascospores. Scale bars: $b=2 \mathrm{~mm}, \mathrm{c}=1 \mathrm{~mm}, \mathrm{~d}=200 \mu \mathrm{m}, \mathrm{e}=40 \mu \mathrm{m}$, $\mathrm{f}=10 \mu \mathrm{m}, \mathrm{g}, \mathrm{h}=100 \mu \mathrm{m}, \mathrm{i}-\mathrm{O}=20 \mu \mathrm{m}$. 
Material examined - AFRICA, Sierra Leone, Njala (Kori), on dead branches of Caesalpinia sappan (Fabaceae), 12 July 1949, F.C Deighton (PDD 14987, co-extype).

Economic significance - None is reported.

Naetrocymbaceae Höhn.

Bonaria Bat., Publicações Inst. Micol. Recife 56: 438 (1959)

Foliar epiphyte on upper and lower surface of living leaves, forming black rounded spots. Mycelium superficial, not apparently penetrating host cells. Sexual morph: Thyriothecia circular, solitary or in groups, gregarious, superficial, carbonaceous, dark brown to black, ostiolate. Peridium comprising a single stratum of black-brown cells of closely arranged textura angularis. Hamathecium comprising asci embedded in pseudoparaphyses. Asci 6-spored, bitunicate, fissitunicate, saccate, globose or subglobose to oblong, apedicellate, apically rounded and endotunica thick-walled near apex without a distinct ocular chamber. Ascospores 2 or 4 seriate, elongate-ellipsoidal, hyaline, 2-celled, slightly constricted at the septum, lower cells slightly longer than upper cell, appearing rough-walled. Asexual morph: Undetermined.

Type species - Bonaria lithocarpi (V.A.M. Mill. \& Bonar) Bat.

Notes - The monotypic genus Bonaria was introduced by Batista to accommodate Bonaria lithocarpi ( $\equiv$ Protopeltis lithocarpi) as the type species. It was placed in the family Micropeltidaceae in Lumbsch \& Huhndorf (2010), however, later, Hyde et al. (2013) excluded the genus from Micropeltidaceae and Wijayawardene et al. (2018) treated the genus in Dothideomycetes, genera incertae sedis. Currently, two other species are accepted in the genus namely, Bonaria chandleri (Hansf.) Bat. and Bonaria phyllanthi Bat. \& C.A.A. Based on the morphological characters, B. lithocarpi shares similar characters to species in Naetrocymbaceae (Hyde et al. 2013, Doilom et al. 2018) such as immersed, subglobose, black ascomata, 8-spored, bitunicate, thick-walled, obpyriform asci and multi-seriate, oblong to long ellipsoid, hyaline, 1septate ascospores. Based on morphological data and unavailability of sequence data, we tentatively place Bonaria in Naetrocymbaceae.

Bonaria lithocarpi (V.A.M. Mill. \& Bonar) Bat., Publicações Inst. Micol. Recife 56: 439 (1959)

E Protopeltis lithocarpi V.A.M. Mill. \& Bonar, University of Calif. Publ. Bot. 19: 412 (1941) Index Fungorum number: IF 293763; Facesoffungi number: FoF 05164

Epifoliar on upper and lower surface of living leaves of Lithocarpus densiflora, forming black rounded spots. Mycelium superficial, not apparently penetrating host cells. Thyriothecia 32$37 \mu \mathrm{m}$ high $\times 148-161 \mu \mathrm{m}$ diam., circular, solitary or in groups, gregarious, superficial, carbonaceous, dark brown to black, ostiolate. Peridium 6-15 $\mu \mathrm{m}$ wide, comprising a single stratum of black-brown cells of closely arranged textura angularis. Hamathecium comprising asci embedded in pseudoparaphyses. Asci 15-26 $\mu \mathrm{m} \times 17-25 \mu \mathrm{m}(\bar{x}=21.3-21.4 \mu \mathrm{m}, \mathrm{n}=10)$, 6-spored, bitunicate, fissitunicate, saccate, globose or subglobose to oblong, apedicellate, apically rounded and endotunica thick-walled near apex without a distinct ocular chamber. Ascospores 14-15 $\mu \mathrm{m} \times$ 2-3 $\mu \mathrm{m}(\bar{x}=14.7 \times 3.3 \mu \mathrm{m}, \mathrm{n}=10), 2$ or 4 seriate, elongate-ellipsoidal, hyaline, 2-celled, slightly constricted at the septum, lower cells slightly longer than upper cell, appearing rough-walled. Asexual morph: undetermined.

Material examined - USA, California, Marin, near Inverness, on Lithocarpus densiflora (Fagaceae), March 1931, H.E. Parks. (S-F 3573, isotype).

Notes - Protopeltis lithocarpi was described by Miller \& Bonaria (1941). Later, Protopeltis was listed as a synonym of Myriangiella in Schizothyriaceae (von Arx \& Müller 1975) and Bonaria was listed as a valid genus in Micropeltidaceae in Lumbsch \& Huhndorf (2010).

Economic significance - The genus Bonaria consists of non-obligate parasites which have been reported on stems of Lachnum marginatum (Cooke) Raitv (Momei 2003). 


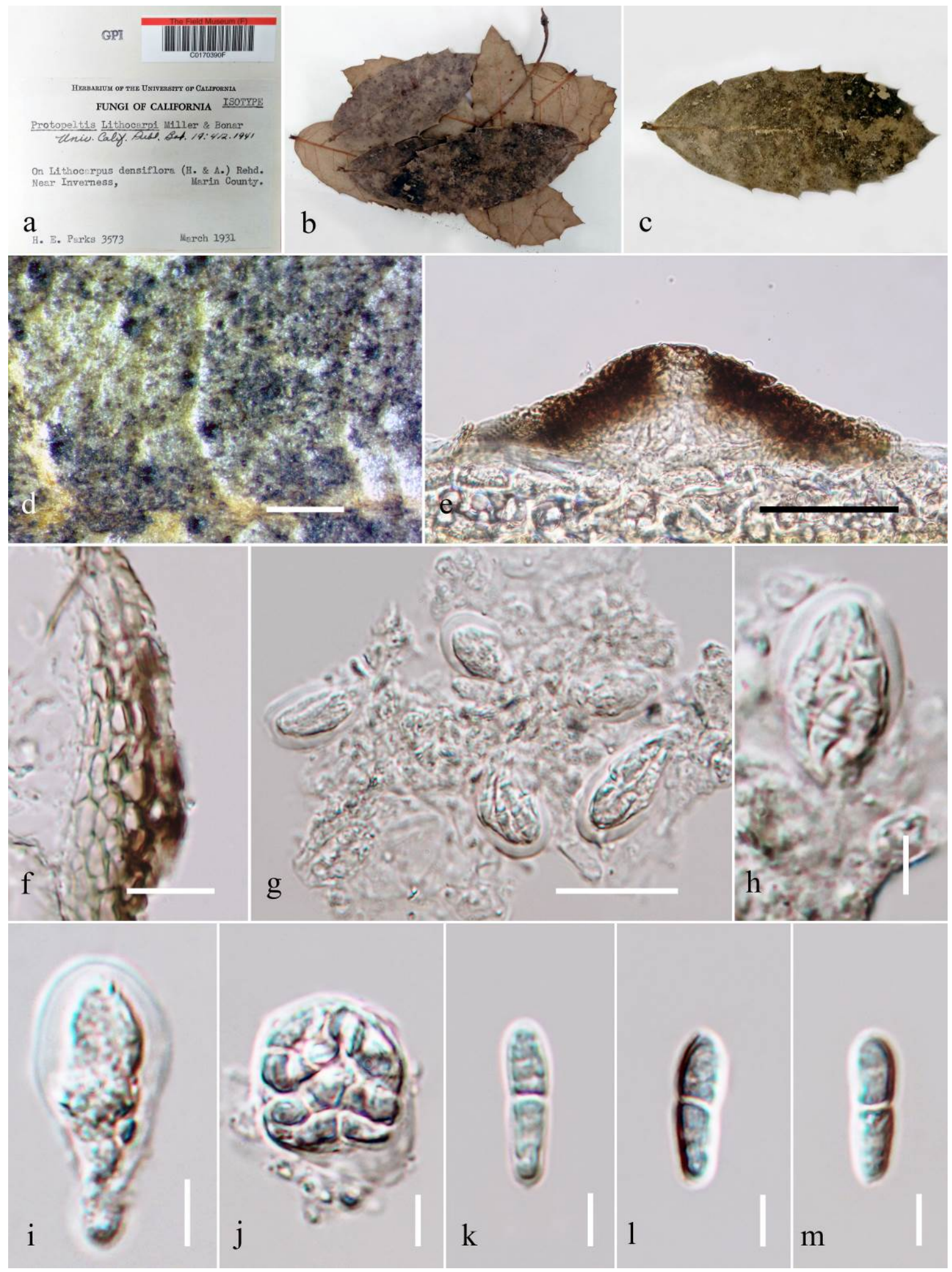

Figure 22 - Bonaria lithocarpi (S-F 3573, isotype) a-c Herbarium specimen and habit on leaf. d Appearance of ascomata on the host surface. e Section of ascoma. $\mathrm{f}$ Peridium g Asci embedded in pseudoparaphyses. $\mathrm{h}-\mathrm{j}$ Asci. $\mathrm{k}-\mathrm{m}$ Ascospores. Scale bars: $\mathrm{d}=500 \mu \mathrm{m}, \mathrm{f}=10 \mu \mathrm{m}, \mathrm{e}, \mathrm{g}=20 \mu \mathrm{m}, \mathrm{h}-$ $\mathrm{m}=5 \mu \mathrm{m}$.

Perisporiopsidaceae E. Müll. \& Arx

Asteronia (Sacc.) Henn., Hedwigia 34: 104 (1895)

$\equiv$ Asterina subgen. Asteronia Sacc., Syll. fung. (Abellini) 1: 47 (1882) 
Parasitic or pathogenic on living leaves of Sweetia sp. Sexual morph: Colonies forming darkened regions on the underside of leaves, similar to a "sooty mold". Ascomata gregarious, solitary or some scattered, superficial, globose, subglobose to ovate, subcoriaceous, brown to black-brown, with an indistinct ostiole. Peridium comprising one layer of black-brown isodiametric cells of textura angularis. Hamathecium not apparent. Asci 8-spored, bitunicate, oblong to broadly cylindrical, with a short indistinct pedicellate or sometime sessile, apically rounded and thickened, with an indistinct ocular chamber. Ascospores tri to multiseriate, guttulate, thin-walled, straight or slightly curved, fusoid-ellipsoidal, widest in the middle part of the apical cell, with broadly rounded apex and tapering to a narrowly rounded base, hyaline, 1-septate, septum nearly central but nearer to apex, rough-walled. Asexual morph: Undetermined.

Type species - Asteronia sweetiae Henn.

Notes - Asteronia was introduced as a monotypic genus with Asteronia sweetiae as the type species. Consequently, Hennings (1908) added A. lauraceae Henn. to the genus. Currently, two species are accommodated in the genus. There is no report of the asexual morph. The genus Asteronia was previously placed in Microthyriaceae by Lumbsch \& Hundorf (2010). Later, Hyde et al. (2013) transferred the genus to Dothideomycetes genera incertae sedis. The genus is characterised by an ascoma that are subglobose and gregarious, and 8-spored asci that are bitunicate with fusoid-ellipsoidal ascospores. Cultures and sequences are unavailable. We re-examined the type specimen of Asteronia sweetiae. The globose ostiolate ascomata formed on black mycelium and lack of flattened thyriothecia indicate that the genus Asteronia does not belong to Microthyriaceae, but is probably a member of Perisporiopsidaceae. The fact that the morphological characters of the genus Asteronia fits well within the species concept of Perisporiopsidaceae in having superficial ascomata with surrounding mycelia, and ellipsoidal oblong, 1 septate, hyaline ascospores, we transfer the genus Asteronia to the family Perisporiopsidaceae.

Asteronia sweetiae Henn., Hedwigia 34: 104 (1895)

Fig. 23

= Parodiopsis sweetiae (Henn.) G. Arnaud, Annls Épiphyt. 7: 53 (1921)

Index Fungorum number: IF 229114; Facesoffungi number: FoF 06215

Parasitic or pathogenic on living leaves of Sweetia sp. Sexual morph: Colonies forming darkened regions on the underside of leaves, similar to a "sooty mold". Ascomata 74-92 $\mu \mathrm{m}$ high $\times$ 67-74 $\mu \mathrm{m}$ diam., gregarious, solitary or some scattered, superficial, globose, subglobose to ovate, subcoriaceous, brown to black-brown, with an indistinct ostiole. Peridium 30-36 $\mu \mathrm{m}$ wide, comprising one layer of black-brown isodiametric cells of textura angularis. Hamathecium not apparent. Asci 60-93 $\mu \mathrm{m} \times 20-27 \mu \mathrm{m}(\bar{x}=72 \times 23 \mu \mathrm{m})$, 8-spored, bitunicate, oblong to broadly cylindrical, with a short indistinct pedicellate or sometime sessile, 8-9 $\mu \mathrm{m}$ long, 6.5-7.5 $\mu \mathrm{m}$ wide, apically rounded and thickened, with an indistinct ocular chamber. Ascospores 33-46 $\mu \mathrm{m} \times 4-6.5$ $\mu \mathrm{m}(\bar{x}=41 \times 5 \mu \mathrm{m})$, tri to multi-seriate, guttulate, thin-walled, straight or slightly curved, fusoidellipsoidal, widest in the middle part of the apical cell, with broadly rounded apex and tapering to a narrowly rounded base, hyaline, 1-septate, septum nearly central but nearer to apex, rough-walled. Asexual morph: Undetermined.

Material examined - BRAZIL, Estado de Minas Gerais, on leaves of Sweetia sp. (Fabaceae), June 1892, E. Ulé (S-F46114, isotype).

Economic significance - The genus Asteronia is associated with dead and living leaves of mostly tropical plants and comprised pathogens, saprobes or epiphytes (Boonmee et al. 2017).

Byssocallis Syd. Annls mycol. 25(1/2): 14 (1927)

Parasitic on mycelium of Meliolaceae on leaves of Phoebes jonduzii. Sexual morph: Ascomata superficial, distributed throughout upper and lower surface of leaf, solitary, subgloboseglobose, light yellow to orange-brown, with an opening at the centre, concealed with light brown mycelia. Peridium comprising 3-4 layers of pale yellow cells of closely arranged textura angularis. Hamathecium 1-1.5 $\mu \mathrm{m}$ wide comprising numerous filiform, branched, septate pseudoparaphyses embedded in a gelatinous matrix. Asci 8-spored, bitunicate, cylindrical to clavate, slightly curved, 
short pedicellate, apically rounded with a small ocular chamber. Ascospores fusiform to clavate, upper part wider than lower part, 3-transversely septate, slightly constricted at the septa, hyaline to grayish, slightly granulated, smooth-walled. Asexual morph: Undetermined.
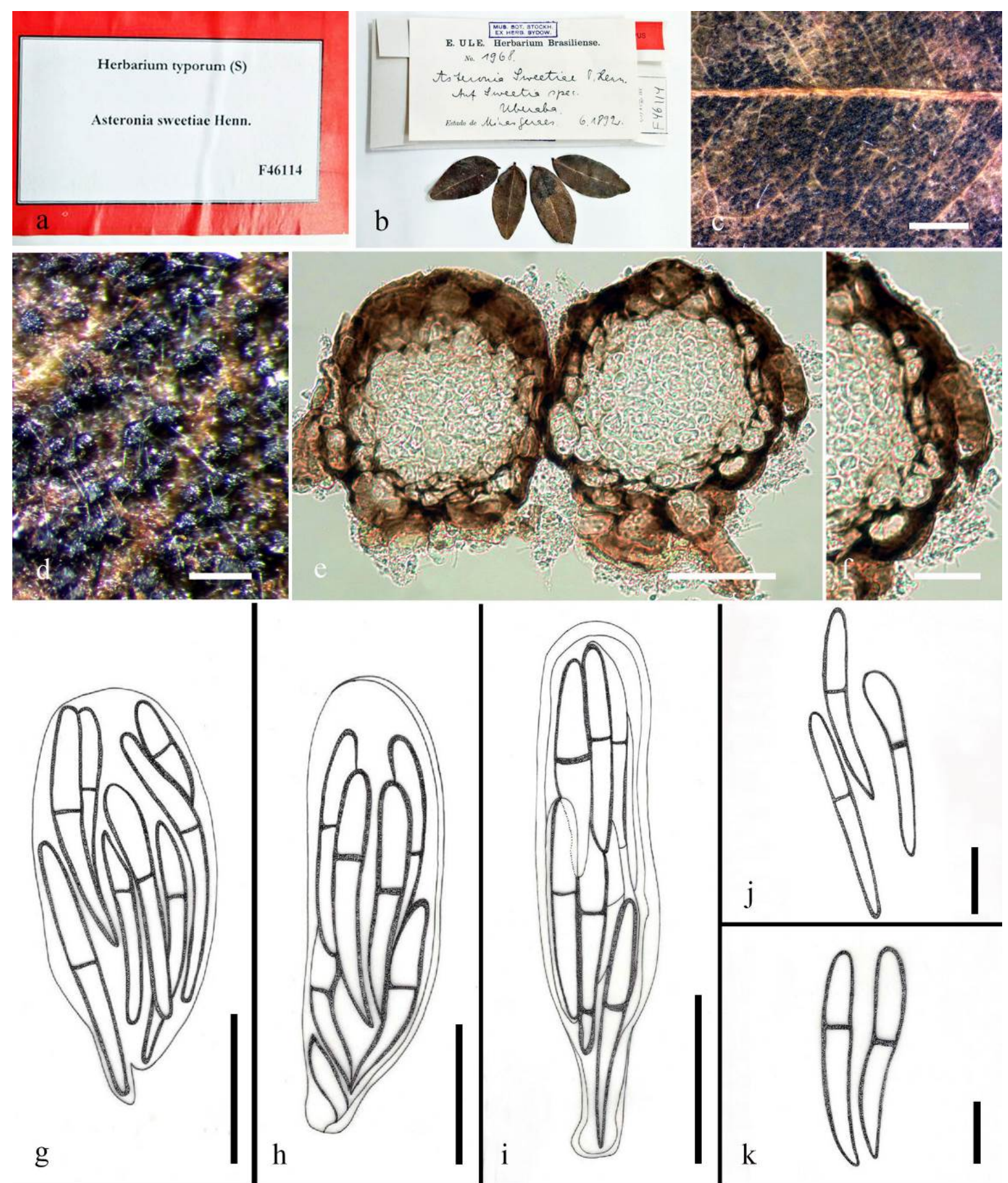

Figure 23 - Asteronia sweetiae (S-F46114, isotype), a, b Details of herbarium material. c, d Habit and appearance of ascomata on host surface. e Section of ascomata. f Peridium. g-i Asci. j, k Ascospores. Scale bars: $\mathrm{c}=1 \mathrm{~mm}, \mathrm{~d}=200 \mu \mathrm{m}, \mathrm{e}=50 \mu \mathrm{m}, \mathrm{f}-\mathrm{i}=20 \mu \mathrm{m}, \mathrm{j}, \mathrm{k}=10 \mu \mathrm{m}$.

Type species - Byssocallis phoebes Syd.

Notes - Byssocallis was introduced with two species B. capensis (Doidge) Rossman and Byssocallis phoebes Syd. The genus is characterized by reticulate, branched, and septate hyphae with colorless mycelium covering the host. Perithecia are solitary to gregarious, superficial, ostiolate with smooth walls. Paraphyses are numerous, narrow, branched with mucous membrane. 
Asci are cylindrical, bitunicate, octosporous. Ascospores are clavate, narrowly fusiform, transverse, hyaline, and multiseptate with the ends often constricted. Species in Byssocallis were found similar to those in Melioliphila except they possess luteous granules in outer cell walls of the ascocarps and hyphae forming the stroma. Byssocallis was previously synonymised with Puttemansia by Petrak (1931) and Pirozynski (1977) based on the presence of apiculate ascospores (Rossman 1987). Byssocallis was accepted as a genus in Tubeufiaceae (Lumbsch \& Huhndorf 2010). Upon further study, the genus Byssocallis was transferred to Dothideomycetes, genera incertae sedis (Hyde et al. 2013, Boonmee et al. 2014, Kirk et al. 2013, Wijayawardene et al. 2014). The asexual morph of this genus is unknown. We re-examined the syntype of Byssocallis phoebes and found similar morphological characters with species accommodated in the family Perisporiopsidaceae. Boonmee et al. (2017) revised the family Perisporiopsidaceae which is characterized by "superficial ascomata with surrounding mycelia, and ellipsoidal oblong, 1 or more septate, hyaline ascospores". Therefore, the genus should be placed in Perisporiopsidaceae (= Parodiopsidaceae) based on morphology.

Byssocallis phoebes Syd., Annls mycol. 25(1/2): 14 (1927)

Fig. 24

Index Fungorum number: IF 274271; Facesoffungi number: FoF 06224

Parasitic on mycelium of leaves of Phoebes jonduzii. Sexual morph: Ascomata 92-113 $\mu \mathrm{m}$ high $\times 105-117 \mu \mathrm{m}$ diam. $(\bar{x}=103.1 \times 111.4 \mu \mathrm{m}, \mathrm{n}=10)$ superficial, distributed throughout upper and lower surface of leaf, solitary, subglobose-globose, light yellow to orange-brown, with an opening at the centre, concealed with light brown mycelia. Peridium 22-25 $\mu \mathrm{m}$ thick, comprising 3-4 layers of pale yellow cells of closely arranged textura angularis. Hamathecium 1-1.5 $\mu \mathrm{m}$ wide comprising numerous filiform, branched, septate pseudoparaphyses embedded in a gelatinous matrix. Asci 69-74 $\mu \mathrm{m} \times 15-18 \mu \mathrm{m}(\bar{x}=71.5 \times 16.8 \mu \mathrm{m}, \mathrm{n}=10)$, 8-spored, bitunicate, cylindrical to clavate, slightly curved, short pedicellate, apically rounded with a small ocular chamber. Ascospores 28-31 $\mu \mathrm{m} \times 8.4-9.1 \mu \mathrm{m}(\bar{x}=29.7 \times 8.7 \mu \mathrm{m}, \mathrm{n}=20)$, fusiform to clavate, wedgeshaped, upper part wider than lower part, 3- transversely septate, slightly constricted at the septa, hyaline to grayish, slightly granulate, smooth-walled. Asexual morph: Undetermined.

Material examined - COSTA RICA, Central America, San Pedro de San Ramon, Provincia de San José on Phoebe costaricanus (Lauraceae), 23 January 1925, H. Sydow (E00455471, syntype).

Economic significance - The genus Byssocallis is parasitic and has been reported to cause disease leaves that occur in Meliolaceae (Boonmee et al. 2011).

Vizellaceae H.J. Swart 1971

Acarella Syd., Annls mycol. 25(1/2): 123 (1927)

Parasitic or epiphytic on the surface of living leaves. Sexual morph: Undetermined. Asexual morph: Pycnidia hypophyllous, dark brown to black, superficial, in groups with irregular margins, sometimes sparsely scattered or not entirely distributed on surface of leaves. Conidiophores straight or slightly curved, hyaline, mostly reduced to conidiogenous cells. Conidiogenous cells phialidic or enteroblastic-percurrent, cylindrical to elliptical, septate, rough and thick-walled. Conidia ellipsoidal to cylindrical, solitary, hyaline to olivaceous-brown, 1-septate, apparently with 2guttules.

Type species - Acarella costaricensis Syd.

Notes - The genus Acarella was described and introduced by Sydow (1927) with the type species, A. costaricensis. Acarella costaricensis was found on unidentified leaves in San Pedro de San Ramon, Peru. Morphologically, this genus is characterized by scattered, small and completely superficial pycnidia with a thin peridium. Conidia are ellipsoid to cylindrical. The sexual morph of this genus is unknown. Species of Acarella are distributed in Central America (Wijayawardene et al. 2017). Cultures and sequences are unavailable. Acarella costaricensis and Perizomella inquinans were isolated from Phoebe costaricana in Costa Rica and is morphologically similar in having ovoid to ellipsoidal or rarely subglobose, brown to dark brown conidia, with transverse 
hyaline band, formed on phialidic, hyaline conidiogenous cells lining the inner cavity of the upper wall. Therefore, considering the host relationship and morphological characters, the species Acarella costaricensis and Perizomella inquinans are synonymised. We therefore transfer the genus Acarella (=Perizomella) to the family Vizellaceae whereby the asexual species exhibit ovoid to ellipsoidal or rarely subglobose, brown to dark brown, with transverse hyaline band, formed on phialidic, hyaline cells lining the inner cavity of the upper wall (Hyde et al. 2013).

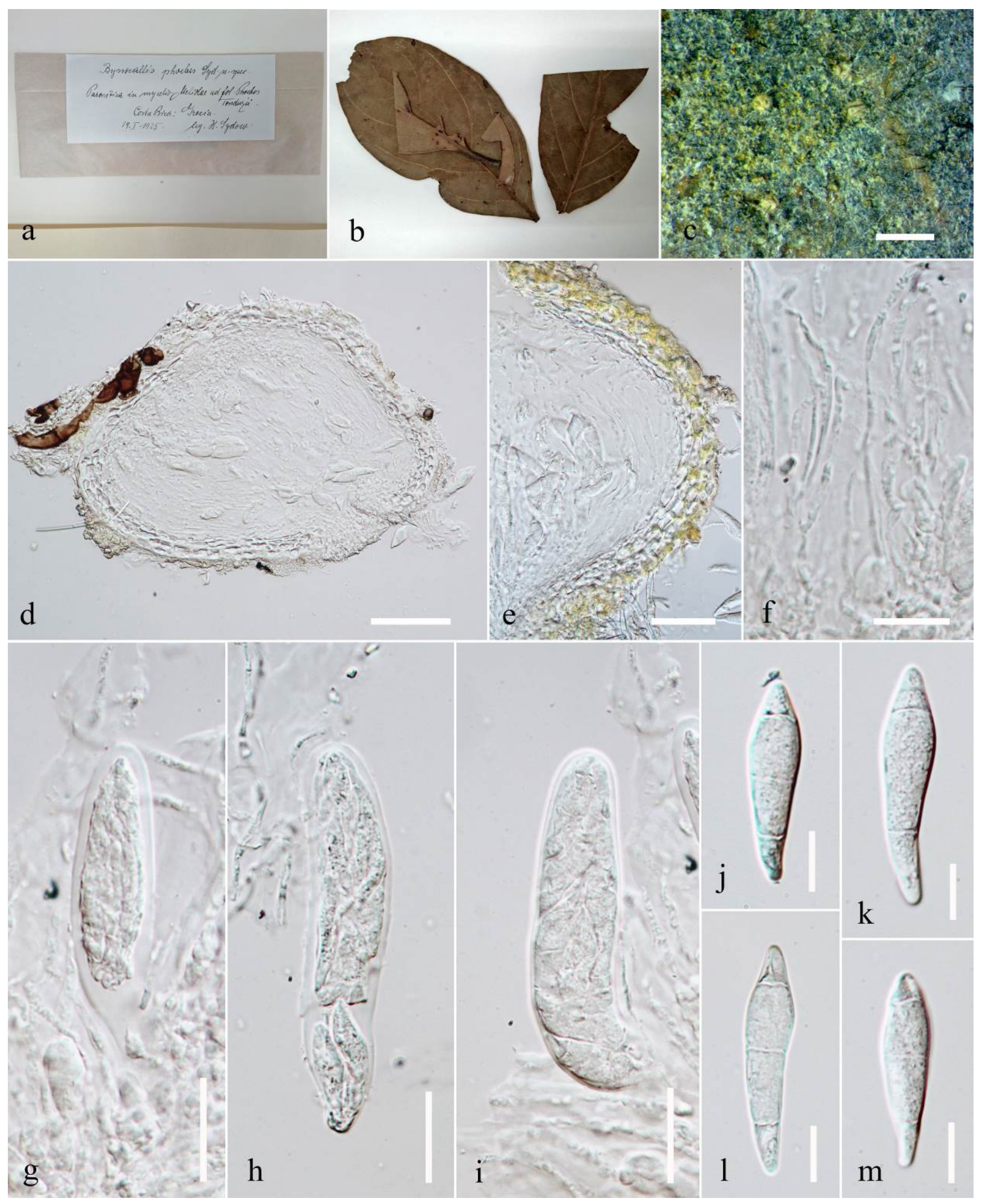

Figure 24 - Byssocallis phoebes (E00455471, syntype). a-c Herbarium specimen and habit on leaf. d Section of an ascoma. e Peridium. f Hamathecium. g-i Asci. j-m Ascospores. Scale bars: $c=500$ $\mu \mathrm{m}, \mathrm{d}=50 \mu \mathrm{m}, \mathrm{e}-\mathrm{i}=20 \mu \mathrm{m}, \mathrm{j}-\mathrm{m}=10 \mu \mathrm{m}$. 
Acarella costaricensis Syd. Annls mycol. 25(1/2): 123 (1927)

Fig. 25

Index Fungorum number: IF 262145; Facesoffungi number: FoF 06207

Parasitic or epiphytic on the surface of living leaves of Phoebe costaricanus. Sexual morph: Undetermined. Asexual morph: Conidiomata 58-110 $\mu \mathrm{m}$ high $\times 36-130 \mu \mathrm{m}$ diam., $(\bar{x}=20.5 \times 4$ $\mu \mathrm{m}, \mathrm{n}=10$ ), pycnidial, hypophyllous, dark brown to black, superficial, in groups with irregular margins, sometimes sparsely scattered or not entirely distributed on surface of leaves. Conidiophores 11-26 $\mu \mathrm{m}$ high, 3-5 $\mu \mathrm{m}$ wide $(\bar{x}=20.5 \times 4 \mu \mathrm{m}, \mathrm{n}=10)$ straight or slightly curved, hyaline, reduced to conidiogenous cells. Conidiogenous cells phialidic or enteroblastic percurrent, cylindrical to elliptical, septate, rough and thick-walled. Conidia 5-6 $62-3 \mu \mathrm{m}(\bar{x}=5 \times 3 \mu \mathrm{m}, \mathrm{n}=$ 10), ellipsoidal to cylindrical, solitary, hyaline to olivaceous-brown, 1-septate, apparently with 2guttules.

Material examined - COSTA RICA, Central America, San Pedro de San ramon, Provincia de San José on Phoebe costaricanus sp. (Lauraceae), 23 January 1925, H. Sydow (E00455227, holotype).

Economic significance - The genus Acarella consist of species with neotropical distribution and form stalked appressoria. They infect the host manifesting as dark brown spots on leaf surfaces (Hofmann 2009). There is no molecular data available for the taxon.

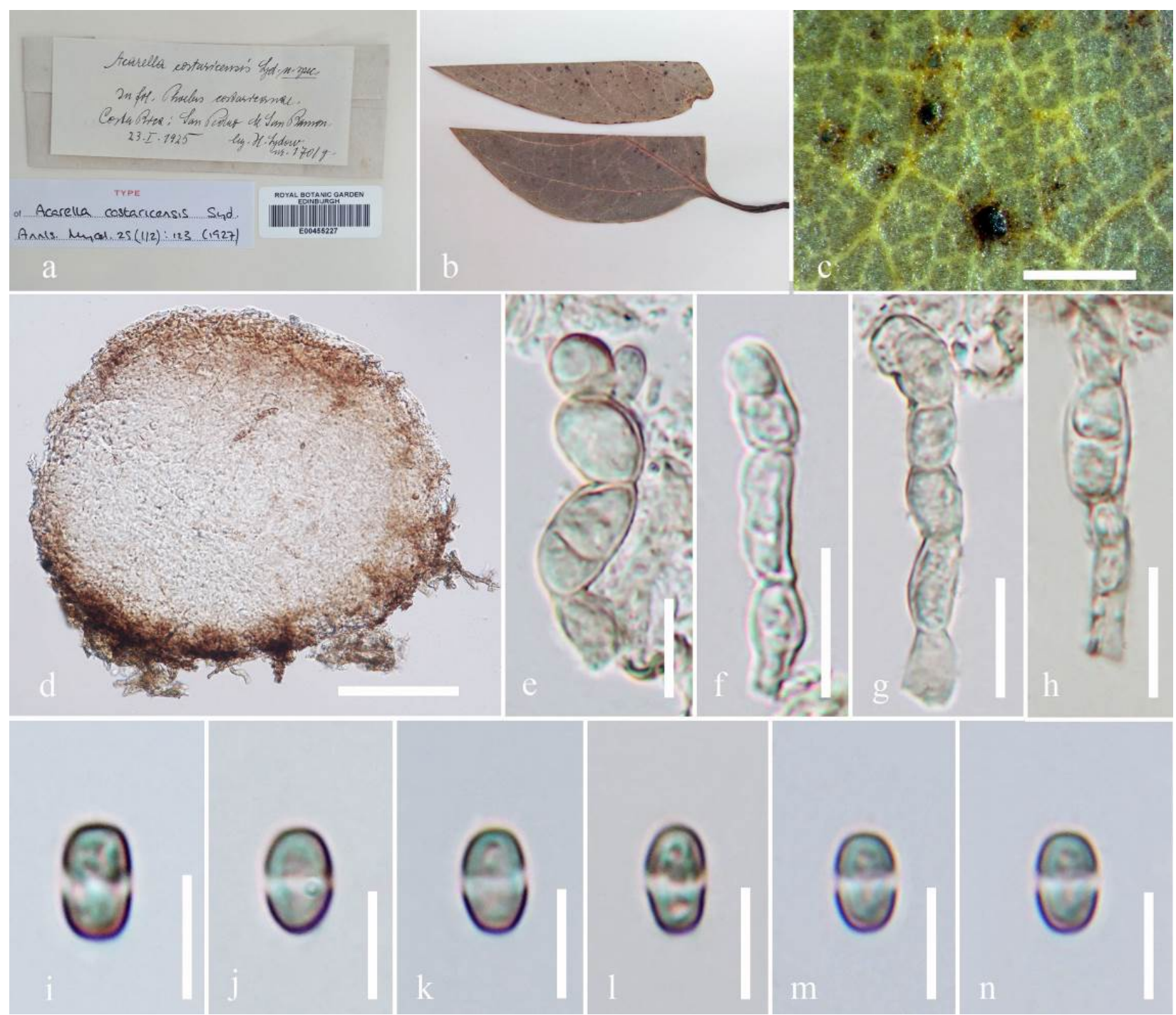

Figure 25 - Acarella costaricensis (E00455227, holotype). a-c Herbarium specimen and habit on leaf. d Section of conidioma. e-h Conidiogenous cells and conidiogenesis. i-n Conidia. Scale bars: $\mathrm{c}=500 \mu \mathrm{m}, \mathrm{d}=100 \mu \mathrm{m}, \mathrm{e}-\mathrm{h}=10 \mu \mathrm{m}, \mathrm{i}-\mathrm{n}=5 \mu \mathrm{m}$. 
Dothideomycetes, genera incertae sedis

Achorella Theiss. \& Syd. Annls mycol. 13(3/4): 340 (1915)

Parasitic or epiphytic on the surface of living leaves. Sexual morph: Undetermined. Asexual morph: Conidiomata pycnidial, eustromatic, superficial, multilocular, black, subglobose, aggregated, thick-walled; walls composed of dark brown textura angularis. Conidiophores hyaline, cylindrical, reduced to conidiogenous cells. Conidiogenous cells phialidic, cylindrical, 1-septate. Conidia hyaline, 2-celled, septate, cylindrical, apical obtuse, smooth-walled with tiny setula or appendage.

Type species - Achorella ametableta (Rehm).

Notes - The genus Achorella was described and introduced by Theissen and Sydow (1915) with A. ametableta as the type species. Achorella ametableta was found on Baccharis (Asteraceae) stems in Brazil and is characterized by globose locules with the perithecial protuberances immersed in the stroma. Locules are spherical to pear-shaped with a short neck. Paraphyses are numerous, thin, cylindrical and filamentous. Ascospores are spindle shaped-constricted on both sides tapered in the middle, brown. It was earlier placed in the Dothideae, within the order Dothideales (Clement 1931), but is now in Dothideomycetes, genera incertae sedis (Wijayawardene et al. 2018). There are currently ten species in this genus. Cultures and sequences are unavailable. The growth of superficial mycelium along with the free perithecium-like protuberances are similar to characters of the species in the Dothideales and of the Perisporiaceae though its closest relation is with the former. The specimen that we observed was in poor condition hence we treat this taxa as doubtful until the fungus is recollected.

Achorella ametableta (Rehm) Theiss. \& Syd, Annls mycol. 13(3/4): 340 (1915)

$\equiv$ Dothidella ametableta Rehm, Hedwigia 36: 376 (1897)

Index Fungorum number: IF 145625; Facesoffungi number: FoF 06208

Fig. 26

Parasitic or epiphytic on the surface of living leaves of Baccharis. Sexual morph: Undetermined. Asexual morph: Conidiomata 100-150 high $\times 140-170 \mu \mathrm{m}$ diam., $(\bar{x}=125 \times 150$ $\mu \mathrm{m}, \mathrm{n}=10$ ), pycnidial, eustromatic, superficial, multilocular, black, subglobose, aggregated, thickwalled; walls composed of dark brown textura angularis. Conidiophores hyaline, cylindrical, reduced to conidiogenous cells. Conidiogenous cells 5-7 $\mu \mathrm{m} \times 2-4 \mu \mathrm{m}(\bar{x}=6 \times 3 \mu \mathrm{m}, \mathrm{n}=10)$, phialidic, cylindrical, 1-septate. Conidia 8-15 $\mu \mathrm{m} \times 2-5 \mu \mathrm{m}(\bar{x}=11 \times 4 \mu \mathrm{m}, \mathrm{n}=20)$, hyaline, 2celled, septate, cylindrical, apical obtuse, smooth-walled with tiny setula or appendage.

Material examined - BRAZIL, Brasilia, Padres Grandes, on Baccharis sp (Asteraceae), August 1880, E. Ule (S-F 47804, holotype).

Economic significance - The genus Achorella is markedly parasitic, causing well defined diseased spots on the host (Steven 1923). The genus has been reported to cause disease in Cohune palm seeds (Janick \& Paull 2008).

Alascospora Raja, Violi \& Shearer, Mycologia 102(1): 33 (2010)

Saprobic on petiole of Nymphaea odorata. Sexual morph: Ascomata superficial to partly immersed, scattered, globose, subglobose or hemispherical and flattened at the base, membranaceous, ostiolate, light brown, translucent when young, darkening with age. Peridium composed of hyaline to brown pseudoparenchymatic cells, with dark brown amorphous material deposited irregularly on the peridial surface, especially dense around the ostiole. Pseudoparaphyses sparsely branched, hyaline to brown, septate, filamentous, cylindrical, at times irregular, sometimes constricted at the septa. Asci bitunicate, fissitunicate, multiguttulate, thick-walled, globose to subglobose, short, pedicellate, containing eight irregularly arranged ascospores, without an ocular chamber, rounded at the apex. Ascospores ellipsoidal, 1-septate, septum thin, hyaline when immature becoming dark brown when mature, upper cell longer and wider than lower cell, with apical papillae and appressed sheath outlining the ascospores. Asexual morph: Undetermined.

Type species - Alascospora evergladensis Raja, Violi \& Shearer 

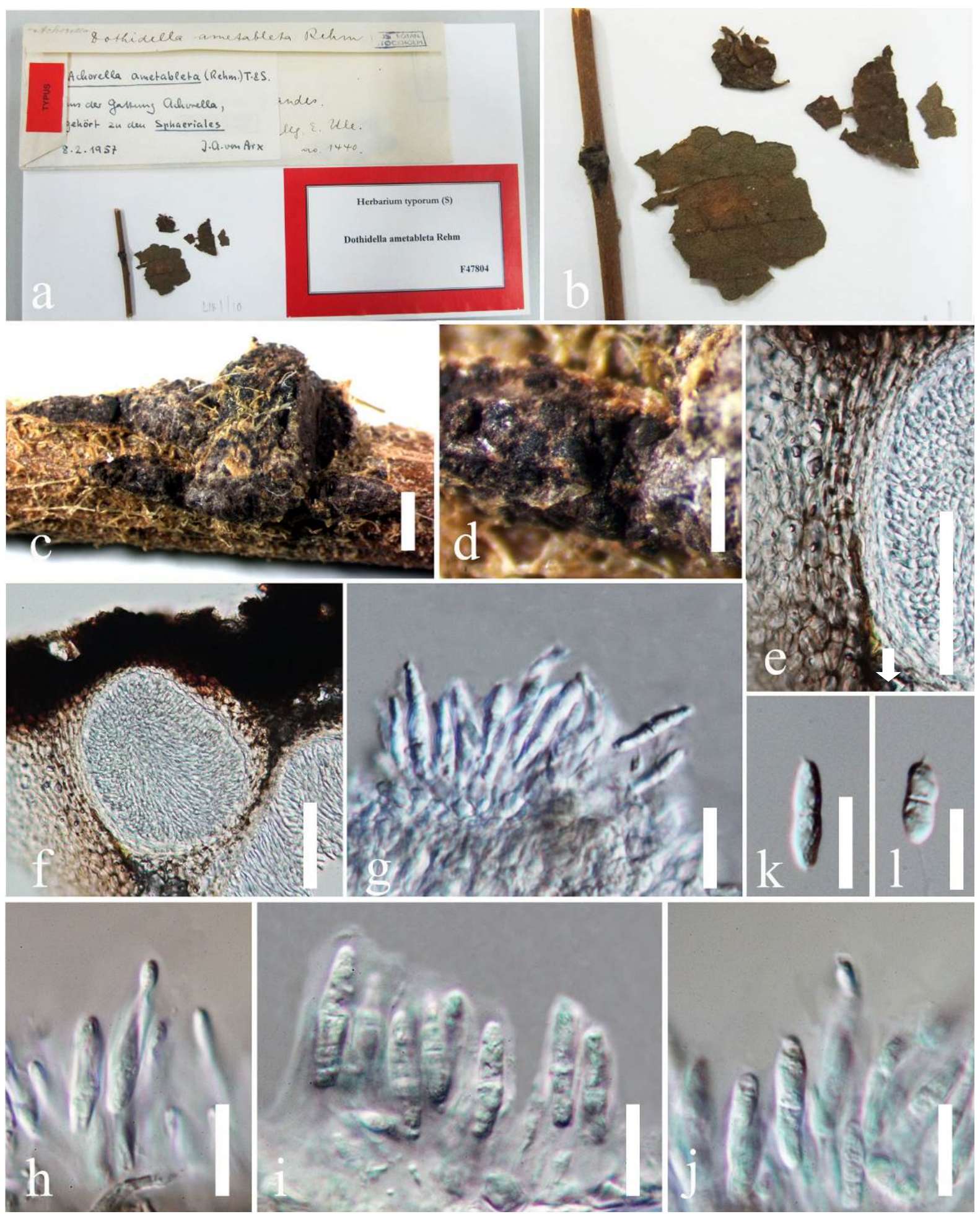

Figure 26 - Achorella ametableta (S-F47804, holotype). a-b Herbarium material. c-d Stroma. e Peridium. f Cross section of conidioma. g Conidia with conidiogenous cell. h-i Conidia, arrow showing tiny setula. Scale bars: $\mathrm{c}=1000 \mu \mathrm{m}, \mathrm{d}=500 \mu \mathrm{m}, \mathrm{e}, \mathrm{f}=50 \mu \mathrm{m}, \mathrm{g}-\mathrm{l}=10 \mu \mathrm{m}$.

Notes - The monotypic genus Alascospora was described and introduced by Raja et al. (2010) with type species, Alascospora evergladensis. The latter was found on petiole of Nymphaea odorata submerged in freshwater in Florida and is characterized by light brown, translucent, membranous, ostiolate ascomata, with dark, amorphous material irregularly deposited on the peridium, near the ostiole; globose, fissitunicate, thick-walled asci; septate pseudoparaphyses; and 1-septate ascospores that are hyaline when immature, and surrounded by a hyaline gelatinous sheath that is wing-shaped and bordered on each side of the ascospores. This genus is also unique 
in its translucent sheath of ascospores which first swells in water and then condenses and darkens around mature ascospores, giving them a dark brown, verruculose look. Alascospora has been compared with Zopfia Rabenh, Pontoporeia (Durieu \& Mont.) Kohlm., and Zopfiofoveola D. Hawksw, Caryospora de Not., in the family Zopfiaceae, as well as Testudina Bizz. and Verruculina Kohlm. \& Volkm.-Kohlm. in family Testudinaceae. The asexual morph of this genus is unknown. Wijayawardene et al. (2017) placed this genus in Dothideomycetes genera incertae sedis. Cultures and sequences are unavailable. We re-examined the microslide of holotype from ILL herbarium under the code ILL40789. Raja et al. (2010) reported the presence of a translucent gelatinous sheath appearing as lateral wings in the border of immature ascospores. However, we could not observe this character from the type material as the microslide was not in good condition. The genus Alascospora is distinct from all other genera of the class Dothideomycetes. However, Alascospora can be compared to Natipusilla to some extent in having aquatic lifestyle, superficial globose ascomata, absence of pseudoparaphyses and ascospores surrounded by sheath. We retain the genus Alascospora in Dothideomycetes, genera incertae sedis.

Alascospora evergladensis Raja, Violi \& Shearer, Mycologia 102(1): 36 (2010)

Fig. 27

Index Fungorum number: IF 514032; Facesoffungi number: FoF 06209

Saprobic on petiole of Nymphaea odorata. Sexual morph: Ascomata 125-232 high $\times 135$ $236 \mu \mathrm{m}$ diam., superficial to partly immersed, scattered, globose, subglobose or hemispherical and flattened at the base, membranaceous, ostiolate, light brown, translucent when young, darkening with age. Peridium 5-10 $\mu \mathrm{m}$ wide, composed of hyaline to brown pseudoparenchymatic cells, with dark brown amorphous material deposited irregularly on the peridial surface, especially dense around the ostiole. Pseudoparaphyses not observed. Asci 38-59 $\mu \mathrm{m} \times 38-63 \mu \mathrm{m}(\bar{x}=54.5 \times 63$ $\mu \mathrm{m}, \mathrm{n}=10$ ), bitunicate, fissitunicate, multiguttulate, thick-walled, globose to subglobose, short, pedicellate, containing eight irregularly arranged ascospores, without an ocular chamber, rounded at the apex. Ascospores 30-35 $\mu \mathrm{m} \times 12-16 \mu \mathrm{m}(\bar{x}=33 \times 14.5 \mu \mathrm{m}, \mathrm{n}=10)$, ellipsoidal, 1-septate, with thin septum, hyaline when immature, becoming dark brown when mature, upper cell longer and wider than lower cell, with apical papillae and appressed sheath outlining the ascospores. Asexual morph: Undetermined.

Material examined - USA, Florida, Everglades Water Management District, Water Conservation Area 2A, phosphorus unenriched site U3, 26 $6^{\circ} 17^{\prime} 15.070^{\prime \prime} \mathrm{N}, 8^{\circ}$ 24'41.08' W, water temperature $19{ }^{\circ} \mathrm{C}, \mathrm{pH} \mathrm{7}$, on submerged petiole of Nymphaea odorata (Nymphaeaceae), 17 November 2008, Huzefa A. Raja and Helen Violi. (ILL40789, micro slide of holotype).

Economic significance - Alascospora evergladensis is a saprobe and plays a role in breakdown and mineralization of organic matter in freshwater habitats (Jones et al. 2000).

Anguillosporella U. Braun, Monogr. Cercosporella, Ramularia Allied Genera (Phytopath. Hyphom.) 1: 233 (1995)

Parasitic on the surface of living leaves. Sexual morph: Undetermined. Asexual morph: Thyriothecia forming amphigenous, subcircular to irregular immarginate, flat, dark brown spots, sparsely scattered or not entirely distributed on surface of leaves. Conidiophores straight or slightly curved, brown, vermiform, curved, sigmoid or flexuose, pluriseptate, thick-walled, with terminal cell reduced to conidiogenous cells. Conidiogenous cells holoblastic, brown, smooth, obpyriform. Conidia solitary, conglobate, hyaline when immature, brown when mature, 1-septate, strongly constricted at the septum, thick-walled.

Type species - Anguillosporella vermiformis (Davis) U. Braun

Notes - The genus Anguillosporella was introduced by Davis (1995) with Anguillosporella vermiformis as the type species, found on Alnus (Betulaceae) in North America. Sexual morph of this genus is unknown. Anguillosporella is characterized by flat, dark brown spots or colonies, vermiform conidiophores, holoblastic conidiogenous cells and conglobate brown conidia. Redhead and White (1985) referred $A$. vermiformis as a phytopathogenic taxon. Wijayawardene et al. (2014) referred Anguillosporella to Dothideomycetes genera incertae sedis. Videira et al. (2017) examined 
the lectotype of $A$. vermiformis and morphologically treated the genus in Mycosphaerellaceae but could not resolve the phylogenetic position of the taxa. Currently the genus comprises two species, Anguillosporella coryli (Redhead \& G.P. White) U. Braun and Anguillosporella vermiformis (Davis) U. Braun. We re-examined the type specimen of A. vermiformis from S herbarium (F4817) in which the conidiophores are seen as macronematous, vermiform, septate and conidiogenous cells as holoblastic. Therefore, we suggest that this genus should be retained in Dothideomycetes genera incertae sedis. The fungus should be recollected and fresh materials must be re-examined.

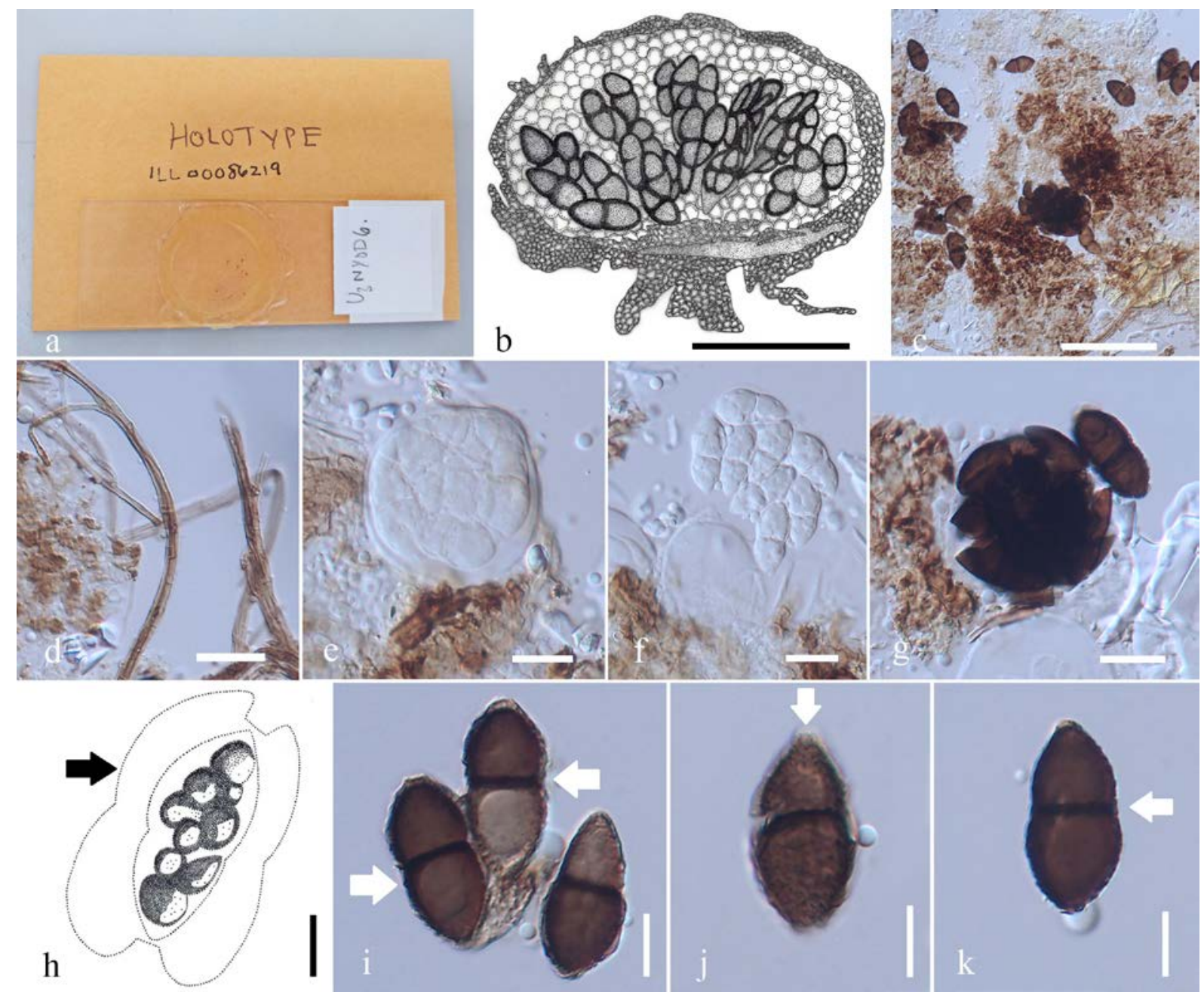

Figure 27 - Alascospora evergladensis (ILL40789, holotype). a Herbarium specimen. b Section of ascoma (redrawn from Raja et al. 2010). c Squash amount of ascomata. d Mycelium. e, f Young, globose, thick-walled ascus. g Globose to subglobose ascus with mature ascospores. h Young, multiguttulate, septate, ascospore with wing-shaped gelatinous sheath (arrows indicate wing-shape gelatinous sheath which swells in water when freshly collected). i Mature ascospores showing verruculose sheath (arrows indicate appressed sheath). $\mathrm{j}-\mathrm{k}$ Spore surface showing appressed sheath that appears verruculose due to condensed sheath (j: arrow indicate apical papillae, k: arrow shows septum). Scale bars: $\mathrm{b}=50 \mu \mathrm{m}, \mathrm{c}=100 \mu \mathrm{m}, \mathrm{d}-\mathrm{g}=20 \mu \mathrm{m}, \mathrm{i}-\mathrm{k}=5 \mu \mathrm{m}$.

Anguillosporella vermiformis (Davis) U. Braun, Monogr. Cercosporella, Ramularia Allied Genera (Phytopath. Hyphom.) 1: 234 (1995)

= Cylindrosporium vermiforme Davis, Trans. Wis. Acad. Sci. Arts Lett. 18(1): 104 (1915)

Index Fungorum number: IF 121640; Facesoffungi number: FoF 06210

Parasitic on the surface of living leaves of Alnus incana. Sexual morph: Undetermined. Asexual morph: Thyriothecia 0.5- $2 \mathrm{~mm}$ high $\times 5-15 \mathrm{~mm}$ diam. $(\bar{x}=0.5 \times 13 \mu \mathrm{m}, \mathrm{n}=10)$, forming amphigenous, subcircular to irregular immarginate, flat dark brown spots, sparsely 
scattered or not entirely distributed on surface of leaves. Conidiophores 18-26 $\mu \mathrm{m}$ high, 3-4 $\mu \mathrm{m}$ wide $(\bar{x}=22 \times 3 \mu \mathrm{m}, \mathrm{n}=10)$, straight or slightly curved, brown, vermiform, curved, sigmoid or flexuose, pluriseptate, thick-walled. Conidiogenous cells holoblastic, brown. Conidia $6-10 \mu \mathrm{m} \times$ 4-6 $\mu \mathrm{m}(\bar{x}=6 \times 5 \mu \mathrm{m}, \mathrm{n}=10)$ solitary, conglobate, hyaline when immature, brown when mature, 1-septate, strongly constricted at the septum, thick-walled.

Material examined - USA, Wisconsin, Devils Lake, Sauk Co. on leaves of Alnusincana sp (Betulaceae), 7 August 1913, J.J. Davis (F4817, holotype).

Economic significance - The genus Anguillosporella is a plant pathogenic genus, causing large, confluent, brown leaf spots and disease on hosts especially on hazelnut (Corylus avellana) (Pscheidt 2012).

Asterinema Bat. \& Gayão, Anais IV Congr. Soc. bot. Brasil: 160 (1953)

Biotrophic or parasitic on living leaves. Colonies forming roundish to irregular blackened blotches, sometimes in groups. Sexual morph: Thyriothecia circular with irregular margin, solitary or gregarious, semi-immersed to superficial, carbonaceous, and black. Peridium comprising several layers of compressed, brown-black, broad cells of textura angularis. Hamathecium sparse, hyaline, septate or aseptate, long pseudoparaphyses inclined towards the center. Asci 8-spored, bitunicate, fissitunicate, obclavate, with a short pedicel. Ascospores biseriate, hyaline, oblong to broadly ellipsoidal or subclavulate, guttulate, slightly constricted at the septum, wall minutely roughened upper cell wider and shorter than the lower cell. Asexual morph: Undetermined.

Type species - Asterinema caseariae Bat. \& Gayão

Notes - Asterinema was introduced as a monotypic genus and accomodated in the family Asterinaceae (Batista \& Gayao 1953, Wu et al. 2011). The genus is typified by A. caseariae which was found in Brazil. Later, three species and one variety were added by Batista et al. (1958). The genus is characterised by superficial hyphae with one-celled appressoria, thyriothecia with an irregular central ostiole and conglobate ascospores. The asci are in a horizontal position from the outer rim inclined towards central ostiole and are cylindro-clavate. The asexual morph of Asterinema is Eriothyrium (Kirk et al. 2008, Hyde et al. 2011). Müller and von Arx (1962) recognized this genus as comprising $A$. caseariae and A. glabratae Bat. \& Maia. Farr (1983) revised the genus accepting only the type species $A$. caseariae, and a newly described variety $A$. caseariae var. amazonense, which was different from the type species in having eight ascospores in the ascus and oppositely arranged hyphopodia. Farr (1983) also placed this genus in Microthyriaceae. Later, Asterinema was excluded from Microthyriaceae because of the arrangement of cells in the thyriothecium (Wu et al. 2011). Cultures and sequences are unavailable hence the genus needs revision. Asterinema is placed in Dothideomycetes genera incertae sedis until recollected and analysed with molecular data.

Asterinema caseariae Bat. \& Gayão, Anais IV Congr. Soc. bot. Brasil: 160 (1953)

Fig. 29

Index Fungorum number: 293427; Facesoffungi number: FoF 06211

Biotrophic or parasitic on living leaves. Colonies $130-311 \mu \mathrm{m}$ wide, $130-275 \mu \mathrm{m}$ high $(\bar{x}=$ $220 \times 210 \mu \mathrm{m}, \mathrm{n}=10$ ), forming roundish to irregular blackened blotches, sometimes in groups. Sexual morph: Thyriothecia 75-48 $\mu \mathrm{m}$ high $\times 105-320 \mu \mathrm{m}$ diam., circular with irregular margin, solitary or gregarious, semi-immersed to superficial, carbonaceous, and black. Peridium 6-10 $\mu \mathrm{m}$ thick, comprising several layers of compressed, brown-black, 3-4 $\mu \mathrm{m}$ broad cells of textura angularis. Hamathecium sparse, hyaline, $1.5 \mu \mathrm{m}$ broad, septate or nonseptate, long pseudoparaphyses inclined towards the center. Asci 50-100 $\mu \mathrm{m} \times 10-16 \mu \mathrm{m}(\bar{x}=80 \times 12 \mu \mathrm{m}, \mathrm{n}=$ 15), 8-spored, bitunicate, fissitunicate, obclavate, with a short pedicel. Ascospores 16-20 $\mu \mathrm{m} \times 6-7$ $\mu \mathrm{m}(\bar{x}=17 \times 6.8 \mu \mathrm{m}, \mathrm{n}=10)$, biseriate, hyaline, oblong to broadly ellipsoid or subclavulate, guttulate, slightly constricted at the septum, wall minutely roughened upper cell wider and shorter than the lower cell. Asexual morph: Undetermined.

Material examined - BRAZIL, on leaves of Casearia sp. (Flacourtiaceae), 30 September 1955, K. P. Dumont (NY00914016, holotype). 


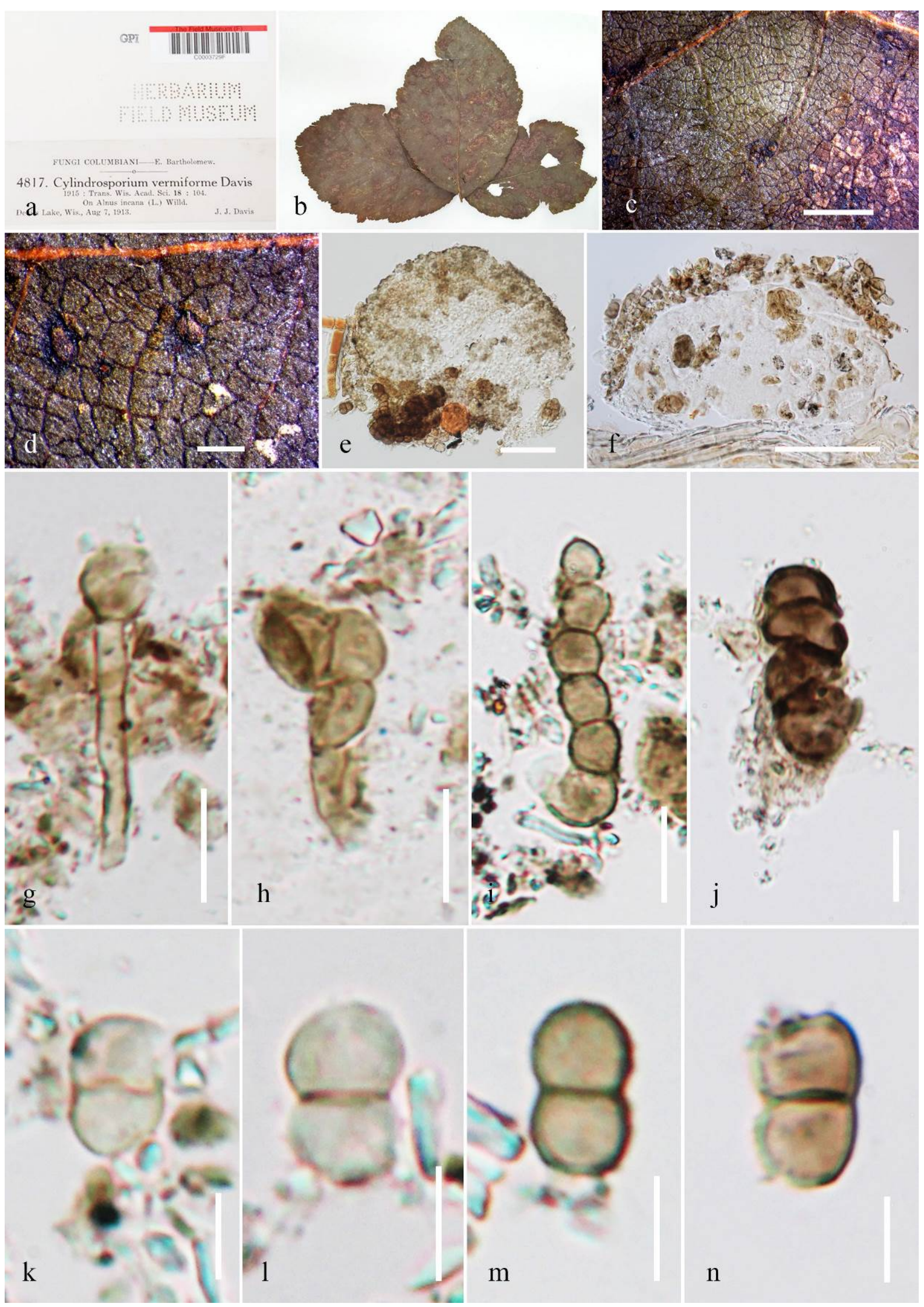

Figure 28 - Anguillosporella vermiformis (F4817, holotype). a-d Herbarium specimen and habit on leaf. e Squash mount of a conidioma. f Section of a conidioma g-j Conidiophore and conidiogenous cells. $\mathrm{k}-\mathrm{n}$ Conidia. Scale bars: $\mathrm{c}=1 \mathrm{~mm}, \mathrm{~d}=500 \mu \mathrm{m}, \mathrm{e}, \mathrm{f}=50 \mu \mathrm{m}, \mathrm{g}-\mathrm{j}=10 \mu \mathrm{m}, \mathrm{k}-$ $\mathrm{n}=5 \mu \mathrm{m}$. 


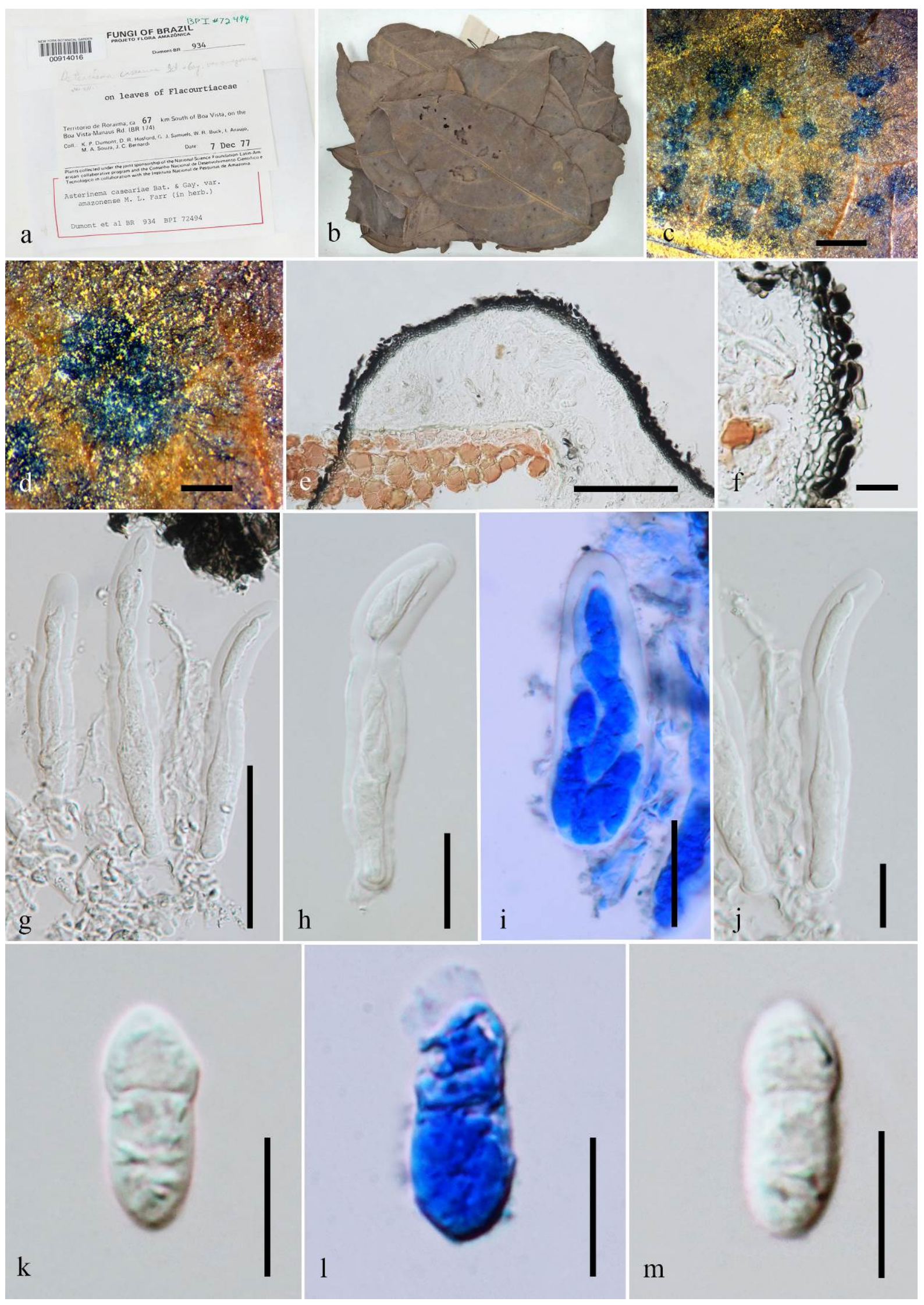

Figure 29 - Asterinema caseariae (NY00914016, holotype). a-b Herbarium specimen and habit on leaf. c, d Appearance of ascomata on leaf surface. e Section of ascoma. f Peridium. g Asci entangled in pseudoparaphyses. $\mathrm{h}-\mathrm{j}$ Asci. $\mathrm{k}-\mathrm{m}$. Ascospores. Note: $\mathrm{i}, \mathrm{l}$ stained in lactophenol cotton blue. Scale bars: $\mathrm{c}, \mathrm{d}=500 \mu \mathrm{m}, \mathrm{e}=100 \mu \mathrm{m}, \mathrm{f}, \mathrm{k}-\mathrm{m}=10 \mu \mathrm{m}, \mathrm{g}=50 \mu \mathrm{m}, \mathrm{h}-\mathrm{j}=20 \mu \mathrm{m}$. 
Economic significance - The genus Asterinema comprises foliicolous fungi or leaf inhabiting fungi that manisfests as black and brown mildew, powdery mildew, smuts and rusts on wide range of hosts (Ali Ganie 2010).

Asteromassaria Höhn., Sber. Akad. Wiss. Wien, Math.-naturw. Kl., Abt. 1 126(4-5): 368 (1917)

Saprobic on unidentified dry twigs in terrestrial habitat. Sexual morph: Ascomata solitary, scattered, or in small groups, immersed, erumpent, depressed globose or subglobose, medium to large, black, ostiolate. Ostiole papillate, opening via a minute slit or a small conical swelling in the bark. Peridium 1-layered, composed of small pigmented thick-walled compressed cells, with base consisting of small, pigmented, thick-walled cells of textura angularis and apex comprising comparatively large cells. Hamathecium of dense, cellular, filiform, broad, septate pseudoparaphyses, embedded in a gelatinous matrix. Asci 8-spored, bitunicate, fissitunicate, broadly cylindrical to broadly cylindro-clavate, with a short, narrow, thick pedicel, rounded at the apex with a small ocular chamber. Ascospores biseriate, partially overlapping, narrowly oblong with broadly to narrowly rounded ends, hyaline, 1-septate, constricted at septum, comprises smooth to verrucose spore wall without a mucilaginous sheath. Asexual morph: Scolicosporium macrosporium (Berk.) B.Sutton. Acervuli immersed in bark, brown, discrete, up to $200 \mu \mathrm{m}$ diam., opening by irregular rupture of the overlaying tissues. Conidiophores cylindrical, 1-2 septate. Conidiogenous cells holoblastic, 1-2 annellate, cylindrical. Conidia fusoid, brown with paler or hyaline ends, 7-17 transversely septate, smooth-walled, with a tapered apex and truncate base.

Type species - Asteromassaria macrospora (Desm.) Höhn.

Notes - The genus Asteromassaria was introduced by Höhnel (1917) with Asteromassaria macrospora (= Sphaeria macrospora Desm.) as the type species which was found on dry twigs in France. Presently, the genus Asteromassaria comprises 12 species (Index Fungorum 2019). Asteromassaria was placed in Pleomassariaceae by Lumbsch and Huhndorf (2010). It was then transferred to Morosphaeriaceae by Zhang et al. (2012). Later, based on morphology, Asteromassaria was moved to Dothideomycetes genera incertae sedis (Hyde et al. 2013, Kirk et al. 2013, Wijayawardene et al. 2014, Wijayawardene et al. 2018). We re-examined the holotype specimen of Asteromassaria macrospora under the code S-F73254 and it is distinct from species in Pleomassariaceae as the latter are characterized by brown to golden brown, muriform ascospores, frequently with a mucilaginous sheath while the type species of Asteromassaria has hyaline 1septate ascospores without mucilaginous sheath. Molecular data are available but lacking for the type species. Only Internal transcribed spacer (ITS) gene and 18S ribosomal RNA gene regions have been deposited for Asteromassaria olivaceohirta and ITS gene for Asteromassaria berberidicola in GenBank. Based on a megablast search using the ITS sequence of Asteromassaria olivaceohirta, the closest matches in NCBI's GenBank nucleotide database were Ulospora bilgramii strain CBS 110020, Neotestudina rosatii strain CBS 690.82, Zopfia rhizophila with identities 99\%, 99\% and 99\% respectively. While those of Asteromassaria berberidicola reveals closest match to unidentified fungal endophyte (STRI: ICBG), Fungal sp. S12 ZLY-2010 and Hendersonia pinicola (EBJul30-4) with identities 89\%, 89\%, and 88\% correspondingly. Based on our multigene-phylogenetic analyses (LSU, SSU, TEF, RPB2) using a strain of Asteromassaria pulchra (CBS 124082), the latter clusters as an independent lineage close to species of Morosphaeriaceae (data not shown). It is clear that the genus Asteromassaria is distinct from all species in the Dothideomycetes. However, more sequences are required to solve its correct taxonomic placement hence, we retain Asteromassaria in Dothideomycetes, genera incertae sedis.

Asteromassaria macrospora (Desm.) Höhn., Sber. Akad. Wiss. Wien, Math.-naturw. Kl., Abt. 1 126(4-5): 368 (1917)

Fig. 30

三Sphaeria macrospora Desm., Annls Sci. Nat., Bot., sér. 3 11(2): 350 (1849)

Index Fungorum number: IF 120830; Facesoffungi number: FoF 06213

Saprobic on unidentified dry twigs in terrestrial habitat. Sexual morph: Ascomata 0.9-1.2 mm high $\times 0.9-1.3 \mathrm{~mm}$ diam. $(\bar{x}=1.5 \times 1.1 \mu \mathrm{m}, \mathrm{n}=10)$, solitary, scattered, or in small groups, 
immersed, erumpent, depressed globose or subglobose, medium to large, black, ostiolate. Ostiole papillate, opening via a minute slit or a small conical swelling in the bark. Peridium 53-65 $\mu \mathrm{m}, 1$ layered, composed of small pigmented thick-walled compressed cells, base consists of small, pigmented, thick-walled cells of textura angularis and apex comprises comparatively large cells. Hamathecium 3.5-4 $\mu \mathrm{m}$ of dense, cellular, filiform, broad, septate pseudoparaphyses, embedded in a gelatinous matrix. Asci 200-245 $\mu \mathrm{m} \times 36-40 \mu \mathrm{m}(\bar{x}=230 \times 38 \mu \mathrm{m}, \mathrm{n}=10)$, 8-spored, bitunicate, fissitunicate, broadly cylindrical to broadly cylindro-clavate, with a short, narrow, thick pedicel, rounded at the apex with a small ocular chamber. Ascospores 50-56 $\mu \mathrm{m} \times 16-22 \mu \mathrm{m}(\bar{x}=$ $54 \times 19 \mu \mathrm{m}, \mathrm{n}=10$ ), biseriate, partially overlapping, narrowly oblong with broadly to narrowly rounded ends, hyaline, 1-septate, constricted at septum, smooth to verrucose, without a mucilaginous sheath. Asexual morph: Scolicosporium macrosporium (Berk.) B. Sutton. Acervuli immersed in bark, brown, discrete, up to $200 \mu \mathrm{m}$ diam., opening by irregular rupture of the overlaying tissues. Conidiophores cylindrical, 1-2 septate, up to $30 \mu \mathrm{m}$ long and 3-5 $\mu \mathrm{m}$ wide. Conidiogenous cells holoblastic, enteroblastic, 1-2-annellate, cylindrical. Conidia 140-190 $\mathrm{mm} \times$ 12-18 $\mu \mathrm{m}$, fusoid, brown, with paler or hyaline ends, 7-10 transverse septate, smooth-walled, with a tapered apex and truncate base.

Material examined - FRANCE, Normandie, in the park of Lébisey near Caen, on unidentified dry twigs, 6 April 1845, Roberge (S-F73254, holotype).

Economic significance - The genus Asteromassaria seems to be a source of an enzyme capable of breaking the middle lamella of bark cells and a biological agent of interest able to digest wood (Shoemaker et al. 2003). Asteromassaria has also been reported to be associated to Mulberry diseases of Japan (Tanaka 2005).

Asteromella Pass. \& Thüm., in Thümen, Mycoth. Univ., cent.17: no. 1689 (1880)

Epifoliar on the upper surface of living leaves. Colonies forming blackened $0.2-0.4 \mathrm{~mm}$ circular areas. Sexual morph: Undetermined. Asexual morph: Pycnidia hypophyllous, dark brown to black, globose to subglobose, superficial with irregular margins, sometimes sparsely scattered or not entirely distributed on surface of leaves. Peridium thick walled comprised of cells of textura globulosa. Conidiophores reduced to conidiogenous cells. Conidiogenous cells enteroblastic, phialidic, integrated or less often discrete, determinate, hyaline (Sutton 1980, van der Aa \& Vanev 2002). Conidia simple, cylindrical to ovoid, hyaline, 1-septate, ellipsoidal to cylindrical, eguttulate.

Type species - Asteromella ovata Thüm.

Notes - Asteromella, introduced by Passerini \& Thümen (1880), is a large genus of plantinhabiting coelomycetous fungi presently referred to Dothideomycetes incertae sedis (Hyde et al. 2011, Wijayawardene et al. 2018). The type species, Asteromella ovata, is a coelomycetous fungus producing minute, bacteria-like spores and was found on leaves of Menispermum canadense in Italy. The characteristics of the type species provided by Thümen (1880) are conidiomata, conidia and dark lesions of host plant leaves caused by the fungus. The genus Asteromella has been critically monographed by Ruszkiewicz-Michalska (2016). Currently, there are around 265 species listed (Index Fungorum 2019). The sexual morph is unknown. We did microscopic observation of the holotype specimen of Asteromella ovata from S herbarium and compared morphological characters with the original protologue. Due to its 'Phoma' like conidia and limited morphological characters, we retain the genus to Dothideomycetes genera incertae sedis.

Asteromella ovata Thüm., Mycoth. Univ., cent.17: no. 1689 (1880)

Fig. 31

Index Fungorum number: IF 197904; Facesoffungi number: FoF 06214

Epifoliar or epiphytes on the upper surface of living leaves leaves of Menispermum canadense L. (Menispermaceae). Colonies forming blackened 0.2-0.4 mm circular areas. Sexual morph: Undetermined. Asexual morph: Pycnidia 250-430 $\mu \mathrm{m}$ high $\times 196-210 \mu \mathrm{m}$ diam., $(\bar{x}=343$ $\times 203 \mu \mathrm{m}, \mathrm{n}=10$ ), hypophyllous, dark brown to black, globose to subglobose, superficial with irregular margins, sometimes sparsely scattered or not entirely distributed on surface of leaves. 
Peridium 13-18 $\mu \mathrm{m}$, thick walled comprised of cells of textura globulosa. Conidiophores reduced to conidiogenous cells.

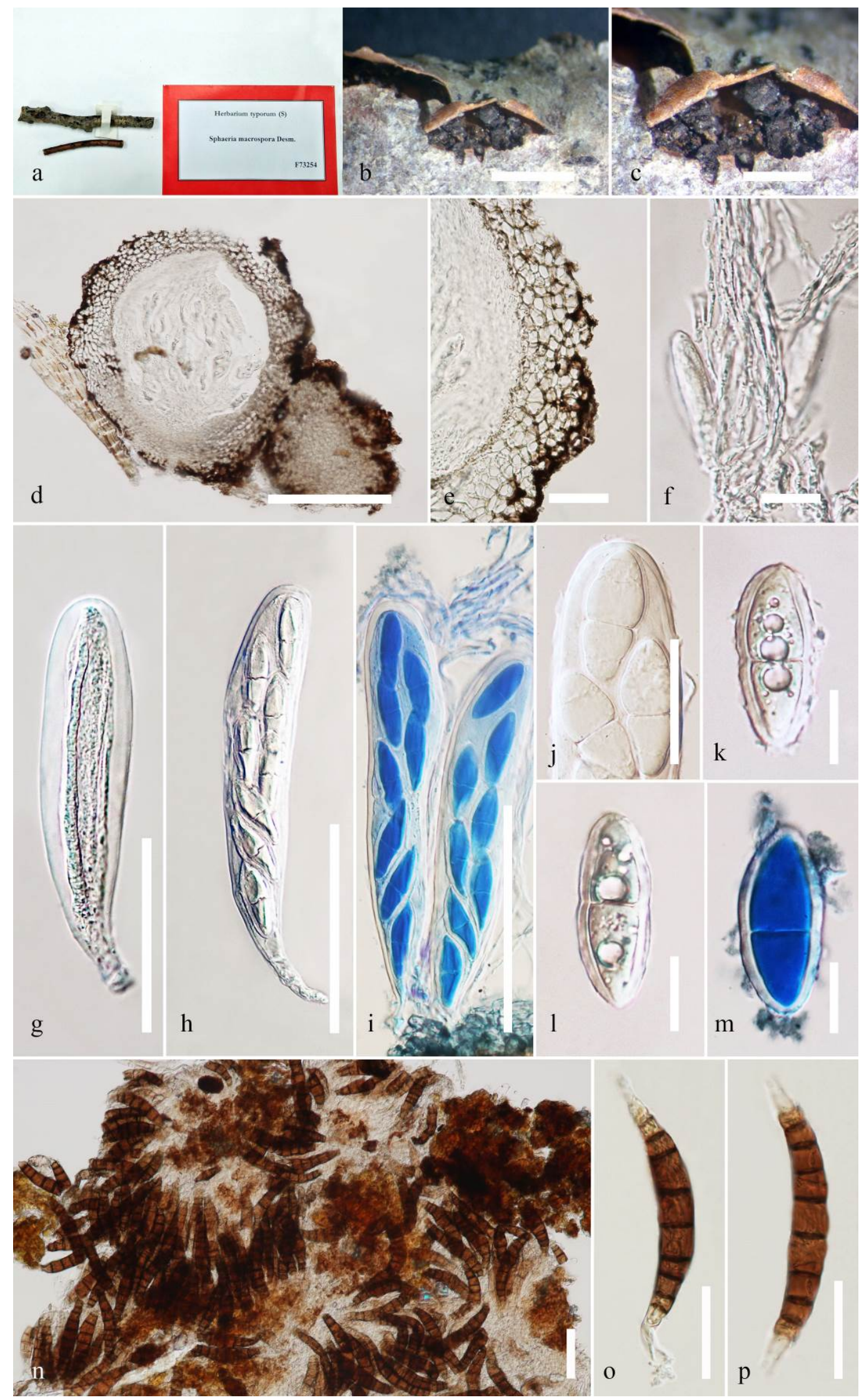

Figure 30 - Asteromassaria macrospora (S-F73254, holotype). a Details of herbarium material. b, c Habit and appearance of ascomata on host surface. d Section of ascomata. e Peridium. $f$ 
Hamathecium. g-j Asci. k-m Ascospores. $\mathrm{n}$ Squash mount of acervuli. o, p Conidia. Scale bars: $\mathrm{b}=$ $2 \mathrm{~mm}, \mathrm{c}, \mathrm{d}=1 \mathrm{~mm}, \mathrm{e}=40 \mu \mathrm{m}, \mathrm{f}=10 \mu \mathrm{m}, \mathrm{g}=30 \mu \mathrm{m}, \mathrm{h}-\mathrm{j}, \mathrm{o}, \mathrm{p}=50 \mu \mathrm{m}, \mathrm{k}-\mathrm{m}=20 \mu \mathrm{m}, \mathrm{n}=100$ $\mu \mathrm{m}$.

Conidiogenous cells enteroblastic, phialidic, integrated or less often discrete, determinate, hyaline (Sutton 1980, van der Aa \& Vanev 2002). Conidia 6.7-8 $\mu \mathrm{m} \times 3-5 \mu \mathrm{m}(\bar{x}=8 \times 5 \mu \mathrm{m}, \mathrm{n}=10)$ cylindrical to ovoid, hyaline, 1-septate, ellipsoid to cylindrical apparently with 2-guttules, eguttulate.

Material examined - PARMA, Parma Botanical Garden, on leaves of Menispermum canadense L. (Menispermaceae), November 1878, Passerini (S-F40912, holotype).

Economic significance - The anamorphic genus Asteromella is a pathogenic genus causing dark lesions, stains, leaf spots and discoloration of host plant leaves in Poland (RuszkiewiczMichalska 2016). Asteromella is also associated with leaf blotch symptom of lime trees (Butin \& Kehr 1995). The genus was also reported on withering leaves of Prunus armeniaca 'Aprikose von Nancy' (Bedlan 2014) as well as ring spots on Brussels sprout and cabbage in UK (Koike et al. 2007). The genus Asteromella is also a pistachio pathogen (Vitale et al. 2018).

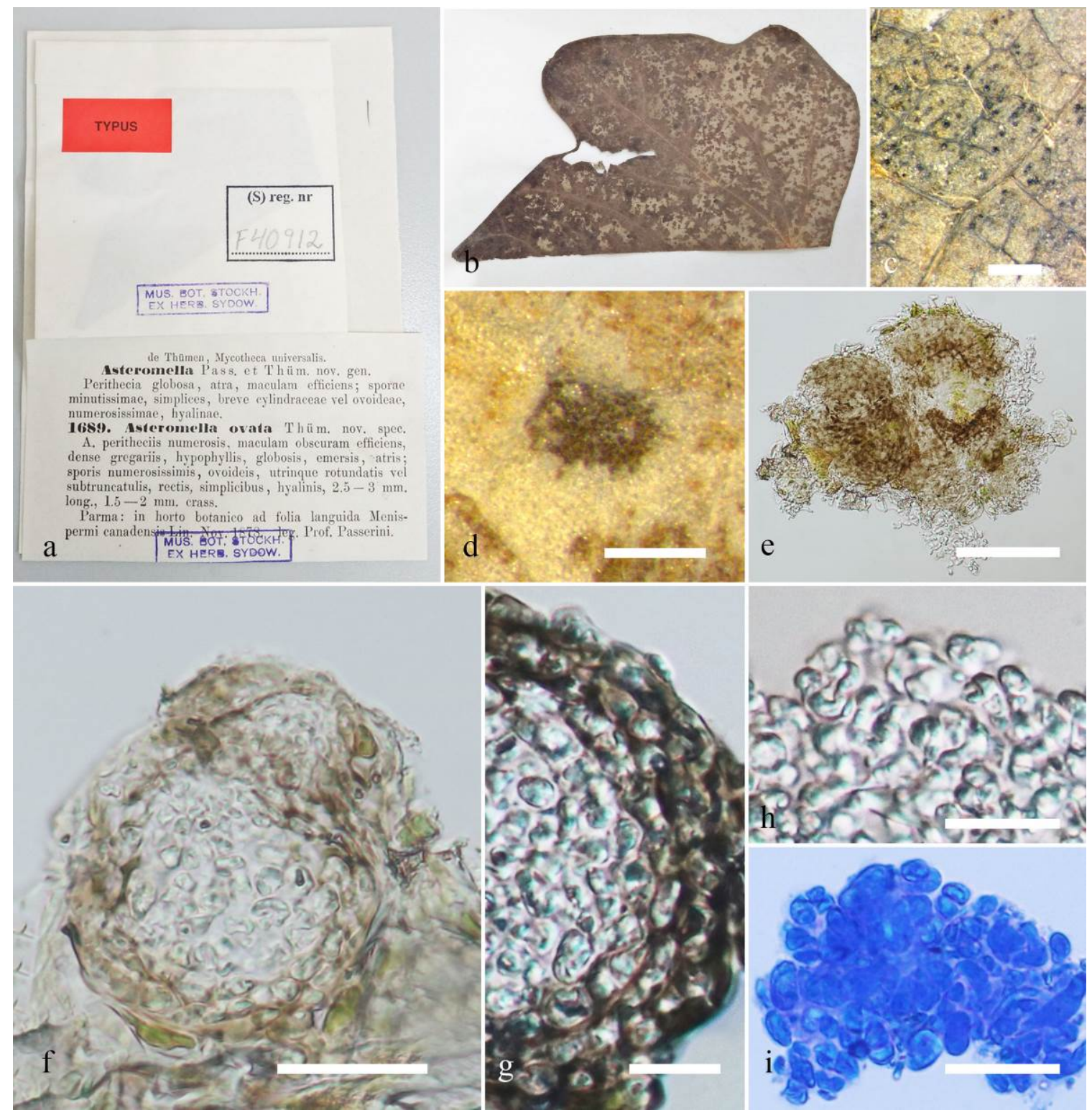

Figure 31 - Asteromella ovata (S-F40912, holotype). a Details of herbarium material. b-d Herbarium specimen and habit on leaf. e Squash mounts of pycnidium. f Section of pycnidium. $g$ 
Peridium. h Conidia. i Conidia stained in lactophenol cotton blue. Scale bars: $\mathrm{c}, \mathrm{d}=2 \mathrm{~mm}$, e, $\mathrm{f}=$ $200 \mu \mathrm{m}, \mathrm{g}=30 \mu \mathrm{m}, \mathrm{h}, \mathrm{i}=10 \mu \mathrm{m}$.

Bactrodesmium Cooke, Grevillea 12(no. 61): 35 (1883)

Pathogenic on dead wood. Sexual morph: Undetermined. Asexual morph: Sporodochia scattered, punctiform, dark-brown. Conidiophores macronematous, mononematous packed together closely to form pulvinate sporodochia, unbranched, mid to dark-brown, smooth, septate. Conidiogenous cells integrated, holoblastic, monoblastic, terminal, cylindrical. Conidia oblongclavate, confluent with the stem, 4 to 6- septate, the lower articulation and the uppermost short, the second from the top very long, solitary, straight to curved, rounded at the tip and truncate at the base, the upper end becoming progressively paler towards the basal cell which is usually subhyaline, with a very dark band at the first septum from the top, smooth.

Type species - Bactrodesmium abruptum (Berk. \& Broome) E.W. Mason \& S. Hughes

Notes - The genus Bactrodesmium is established by Cooke (1883) to accommodate Sporidesmium abruptum Berk. and Br., Sporidesmium spilomeum Berk. and Br. Sporidesmium abruptum was transferred to Bactrodesmium but the binomial was invalidly published. The combination was later validated by Mason \& Hughes (1958), and B. abruptum was designated as the lectotype species of Bactrodesmium. Two new species namely, B. opacum and B. clavulatum were later added to the genus Bactrodesmium by Cooke \& Harkness (1884). Currently, more than 48 epithets are accommodated in the genus Bactrodesmium (Index Fungorum 2019). The sexual morph is reported to be Stuartella spp. (Wijayawardene et al. 2018). The genus is heterogeneous and includes species with pseudoseptate conidia, such as B. rahnii M.B. Ellis (Ellis 1976) or euseptate, with or without presence of black bands in the septa. They are rarely verrucose as in Bactrodesmium palmicola Mercado, Heredia \& J. Mena (Mercado-Sierra et al. 1995) or with longitudinal septa such as Bactrodesmium indicum Reghuveer (Rao 1983). The genus Bactrodesmium is identified by its sporodochial conidiomata and hyaline or brown, simple or branched conidiophores associated with mono- or polyblastic conidiogenous cells (Ellis 1971, Holubova-Jechova 1972). According to a study conducted by Hernandez-Restrepo (2013) based on B. obovatum (FR870265), B. pyriforme (FR870266) and B. pyriforme (HE646637), the genus Bactrodesmium clusters in Sordariomycetes, genera incertae sedis. In the analyses conducted by (Hernandez-Restrepo 2017), Bactrodesmium pallidum (FMR 11345) formed a clade in the Savoryellaceae, Bactrodesmium gabretae (ZK) was basal to Calycina citrigena (ILLS 61033) while Bactrodesmium cubense (CBS 680.96) was basal to Morosphaeria velatispora (KH 218). In our phylogenetic analyses using LSU and ITS sequences available in GenBank, the strain Bactrodesmium gabretae (ZK) is basal to Dermea acerina (CBS 161.38) which is accommodated in Leotiomycetes; Bactrodesmium pallidum (FMR 11345) is basal to Bahusakala longispora (CBS 544.84) in Sordariomycetes while Bactrodesmium cubense (CBS 680.96) is basal to Morosphaeria ramunculicola (BCC 18404) in Morosphaeriaceae (data not shown). The genus Bactrodesmium is polyphyletic and taxonomy is still unresolved because of its potential high diversity and lack of DNA sequences. More cultures and DNA sequences are required to build the phylogenetic tree of Bactrodesmium and resolve its correct taxonomic position. We illustrate the characters of the genus Bactrodesmium by re-examining the type specimen Sporidesmium abruptum Berk. Br. under the code IMI 6833. The genus needs epitypifying or a reference specimen. Based on morphological characters, we retain the genus Bactrodesmium sensu stricto in Dothideomycetes, genera incertae sedis.

Bactrodesmium abruptum (Berk. \& Broome) E.W. Mason \& S. Hughes, in Hughes, Can. J. Bot. 36: 738 (1958)

Fig. 32

三Sporidesmium abruptum Berk. \& Broome, Ann. Mag. nat. Hist., Ser. 3 15: 401 (1865)

Index Fungorum number: IF 162285; Facesoffungi number: FoF 06216

Pathogenic on dead wood. Sexual morph: Undetermined. Asexual morph: Sporodochia 216 $276 \mu \mathrm{m}$ diam., scattered, punctiform, dark-brown. Conidiophores 13-20 $\mu \mathrm{m} \times 4-6 \mu \mathrm{m}(\bar{x}=17 \times 5$ 
$\mu \mathrm{m}, \mathrm{n}=20$ ), macronematous, mononematous, packed together closely to form pulvinate sporodochia, unbranched, mid to dark-brown, smooth, septate. Conidiogenous cells integrated, holoblastic, monoblastic, terminal, cylindrical. Conidia 42-66 $\mu \mathrm{m} \times 11-19 \mu \mathrm{m}(\bar{x}=51 \times 16 \mu \mathrm{m}, \mathrm{n}$ $=20$ ), oblong-clavate, confluent with the stem, 4-6-septate, the lower articulation and the uppermost short, the second from the top very long, solitary, straight to curved, rounded at the tip and truncate at the base, the upper end becoming progressively paler towards the basal cell which is usually sub-hyaline, with a very dark band at the first septum from the top, smooth.

Material examined - UK, on dead wood, March 1964, Bloxam, (IMI 6833, holotype).

Economic significance - The genus Bactrodesmium is associated with degradation of rubber wood logs and leaf litter (Seephueak 2012). The genus can also infect living hosts such as white spruce (Picea), Betula species and others reducing the economic value of plants (Bagdžiūnaitė 2006). The genus Bactrodesmium has also been isolated from apple green leaves or dead leaves as pathogens (Bernier 1996).

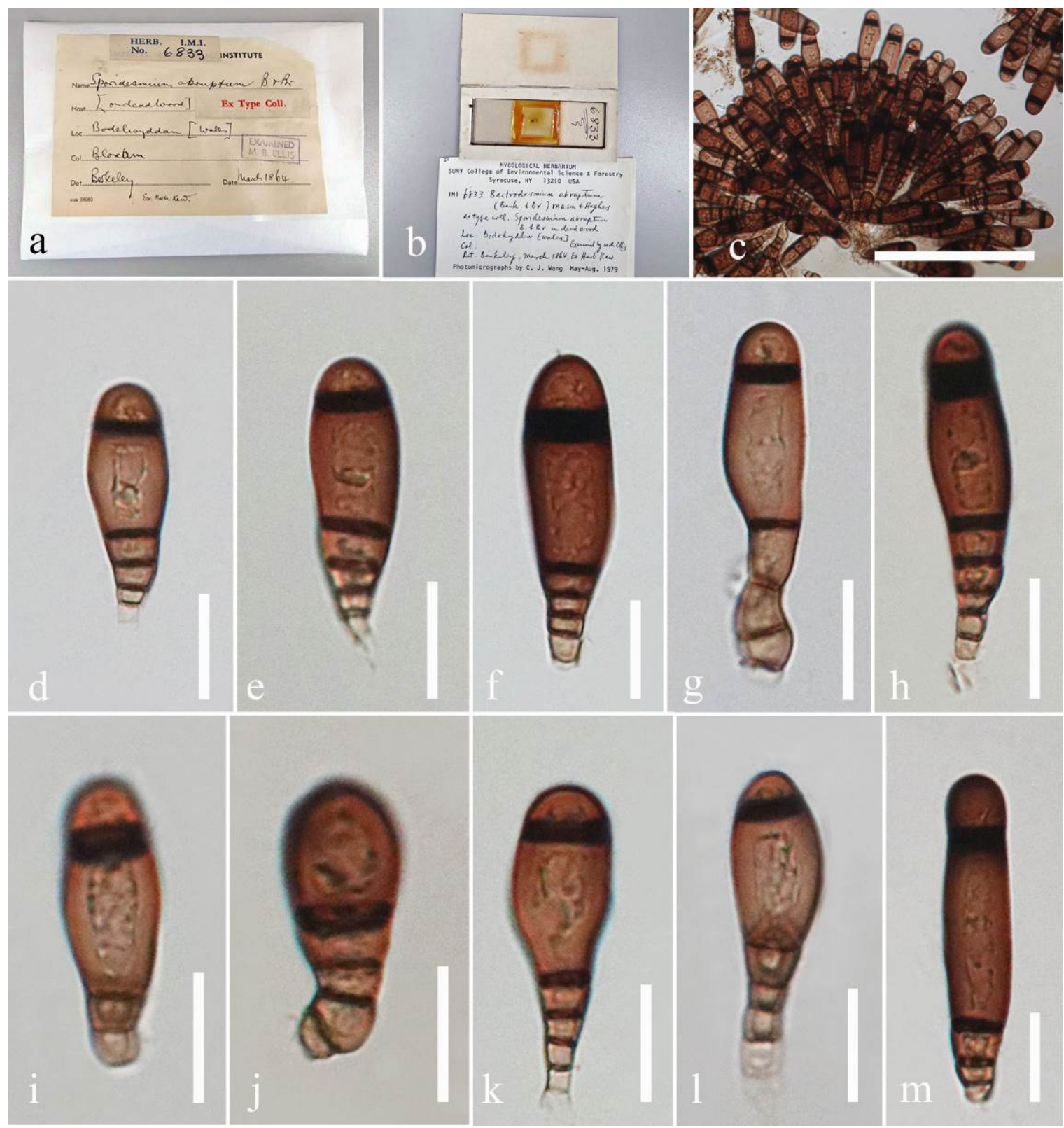

Figure 32 - Bactrodesmium abruptum (IMI 6833, holotype). a, b Herbarium material. e Squash mount of a conidioma showing sporodochia. $\mathrm{d}-\mathrm{m}$ Conidiophores and conidia. Scale bars: $\mathrm{c}=50$ $\mu \mathrm{m}, \mathrm{d}-\mathrm{m}=20 \mu \mathrm{m}$. 
Botryostroma Höhn., Sber. Akad. Wiss. Wien, Math.-naturw. Kl., Abt. 1 120: 424 (1911)

Saprobic on leaves of unidentified host. Sexual morph: Undetermined. Asexual morph: Conidiomata pycnidial, small, very dense or compact, rounded, circular or irregular, black, verrucose, growing from a subcuticular hypostroma, forming a thin single-celled, pseudoparenchymatous, translucent olive-brown crust, depressed in the dried state, papillate. Conidiomata wall outer layer thick, 7-8 layered, composed of thick-walled dark brown to black cells of textura globulosa, innermost wall thin, 2-3 layered of textura angularis, becoming hyaline. Conidiophores reduced to conidiogenous cells. Conidiogenous cells cylindrical or slightly irregular, short, sparsely branched, mostly at the base, hyaline or very pale brown, septate, smooth. Conidia straight, curved or irregular, truncate at the base, obtuse at apex, hyaline or pale brown, multiseptate, usually thin and smooth-walled or verruculose.

Type species - Botryostroma inaequale (G. Winter) Höhn.

Notes - The genus Botryostroma was introduced by Höhnel (1911). The genus is characterised by black ascomata produced under a clypeus, with numerous persistent pseudoparaphyses among asci. The genus was accommodated in Venturiaceae by Muller \& von Arx (1962) based on its obclavate or fusiform asci, lightly pigmented, apiosporous ascospores. The asexual morph is coelomycetous. Due to its uncertain taxonomic placement, Botryostroma was accepted as a genus in Dothideomycetes, genera incertae sedis (Kirk et al. 2013, Wijayawardene et al. 2017). Currently, two species are accommodated in the genus. Cultures and sequences are unavailable. We re-studied the holotype specimen of Botryostroma inaequale under the basionym Lizonia inaequalis G. Winter with the code F10863 from S herbarium. We did not observe any sexual characters in the specimen. Based on the asexual morphological characters, we are uncertain regarding the taxonomic placement of the genus, hence we retain Botryostroma in Dothideomycetes, genera incertae sedis.

Botryostroma inaequale (G. Winter) Höhn. [as 'inaequalis'], Sber. Akad. Wiss. Wien, Math.naturw. Kl., Abt. 1 120: 425 (1911)

Fig. 33

三Lizonia inaequalis G. Winter, Hedwigia 24(6): 261 (1883)

Index Fungorum number: IF636; Facesoffungi number: FoF 06222

Saprobic on leaves of unidentified host. Sexual morph: Undetermined. Asexual morph: Conidiomata 194-259 $\mu \mathrm{m}$ diam., 187-206 $\mu \mathrm{m}$ high, pycnidial, small, very dense or compact, rounded circular or irregular, black, verrucose, growing from a subcuticular hypostroma, forming a thin celled layer, pseudoparenchymatous, translucent olive-brown crust, depressed in the dried state, papillate. Conidiomatal wall outer layer thick, 7-8 layered, composed of thick-walled dark brown to black cells of textura globulosa, innermost wall thin, 2-3 layered of textura angularis, becoming hyaline. Conidiophores reduced to conidiogenous cells. Conidiogenous cells 3.5-5.9 $\mu \mathrm{m}$ $\times 2.3-3.5 \mu \mathrm{m}$, holoblastic, cylindrical or slightly irregular, short, sparsely branched, mostly at the base, hyaline or very pale brown, septate, smooth. Conidia $20-26 \mu \mathrm{m} \times 3.0-4.3 \mu \mathrm{m}(\bar{x}=21.8 \times 3.4$ $\mu \mathrm{m}, \mathrm{n}=20$ ), straight, curved or irregular, truncate at the base, obtuse at the apex hyaline or pale brown, 3-transversely septate, usually thin and smooth-walled or verruculose.

Material examined - BRAZIL, close to San Franscisco, leaves of unidentified host, August 1884, E.Ule (S-F10863, holotype).

Economic significance - None is reported.

Bryorella Döbbeler, Mitt. bot. StSamml., Münch. 14: 128 (1978)

Saprobic or parasitic on leaves or the stem of wood moss (Hylocomiaceae) in terrestrial habitat. Sexual morph: Ascomata erumpent to completely superficial, solitary, spherical, globrous, dark brown to black, short papillate. Peridium wall composed of 2 layers, an outer layer comprising small, heavily pigmented, thick-walled cells of textura angularis and an inner layer comprising lightly pigmented to hyaline, thin-walled cells of textura angularis. Hamathecium of dense, filamentous, branching, anastomosing, non-septate, hyaline pseudoparaphyses. Asci 8-spored, cylindrical, with a short pedicel or sessile, rounded at the apex, with an ocular chamber, sometimes 
bulbous expanded below. Ascospores uniseriate, elongated, ellipsoidal or rarely spindle, constricted at septa, 3-7-transversely septate, obtuse apex, sometimes narrow below, hyaline when immature to dark brown when mature, thick-walled, smooth. Asexual morph: Undetermined.

Type species - Bryorella acrogena Döbbeler

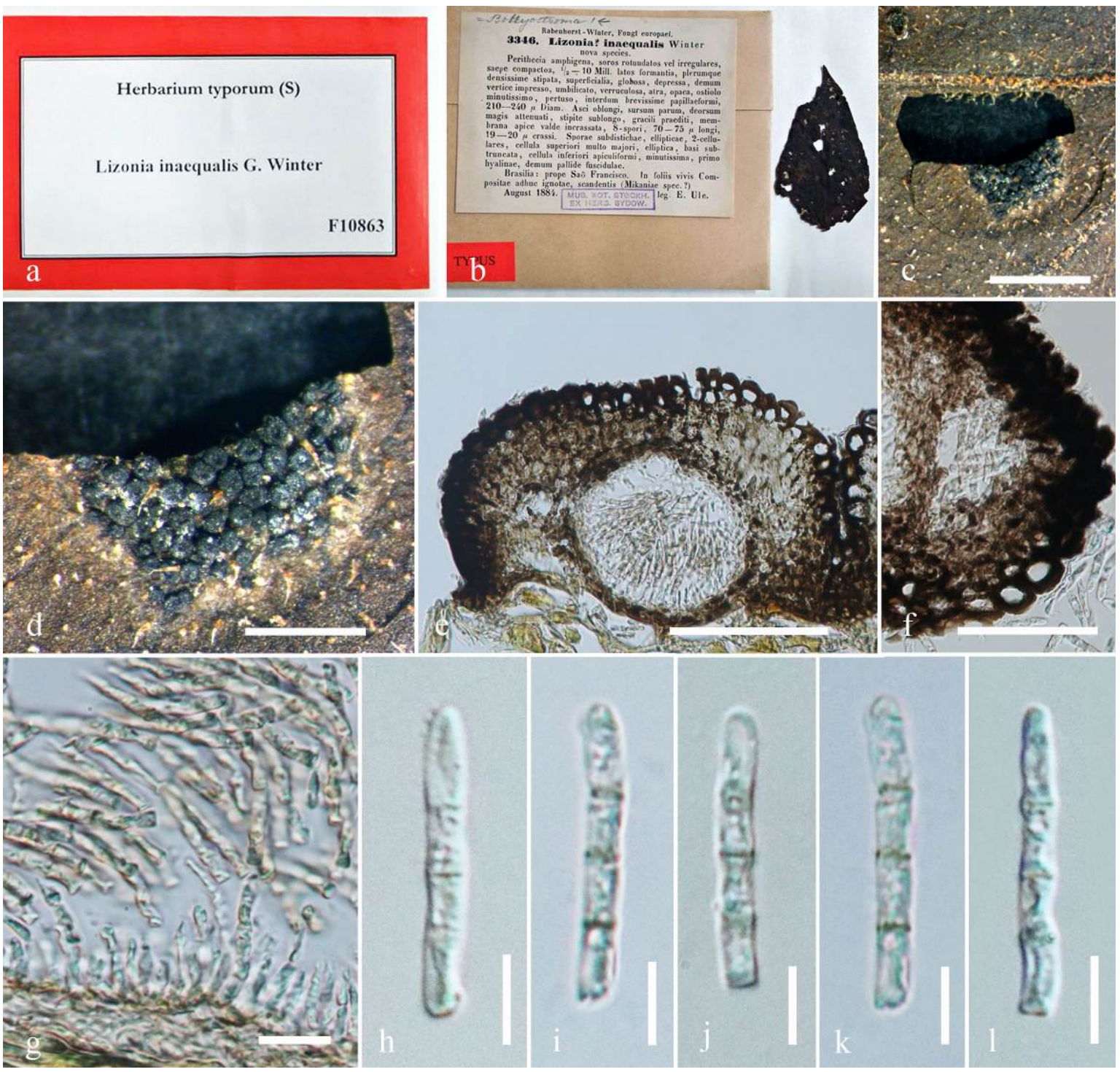

Figure 33 - Lizonia inaequalis (S-F10863, holotype). a Details of herbarium material. b-d Habit and appearance of conidiomata on host surface. e Section of conidioma. $\mathrm{f}$ Peridium. g Conidiogenesis. $\mathrm{h}-\mathrm{l}$ Conidia. Scale bars: $\mathrm{c}=2 \mathrm{~mm}, \mathrm{~d}=1 \mathrm{~mm}, \mathrm{e}=100 \mu \mathrm{m}, \mathrm{f}=50 \mu \mathrm{m}, \mathrm{g}=10 \mu \mathrm{m}$.

Notes - Bryorella was introduced by Döbbeler (1978) with nine species namely, B. acrogena, B. compressa Döbbeler, B. crassitecta Döbbeler, B. cryptocarpa Döbbeler, B. erumpens Döbbeler, B. gregaria Döbbeler, B. punctiformis Döbbeler \& Poelt, B. retiformis Döbbeler \& Poelt and B. semi-immersa Döbbeler, with $B$. acrogena as the type species. Bryorella acrogena was found on Hylocomium splendus in Austria. Since then, two more species were added (Döbbeler 1981, 1982, 2007). Li et al. (2014) re-examined the type species of Bryorella and described the genus as characterized by superficial, disseminated, glabrous, small, ascomata with a cellular peridium, hyaline ascospores and a hymenium lacking a reaction in iodine ( $\mathrm{Li}$ et al. 2014). However, the author did not observe any asci and ascospores and placed the genus in Dothideomycetes, genera incertae sedis. We re-examined another specimen from UME and found different morphological characters such as elongated ellipsoidal brown ascospores instead of hyaline ascospores as described by Li et al. (2014). 
The taxon has narrow, anastomosing pseudoparaphyses that are typical of Melannomataceae (Tian et al. 2014), and it might be placed in this family. Liew et al. (2000) however, showed that such structures were only significant at the genus or species level. We therefore retain the genus in Dothideomycetes genera incertae sedis, until fresh specimens are collected and re-examined.

Bryorella acrogena Döbbeler, Mitt. bot. StSamml., Münch. 14: 131 (1978)

Index Fungorum number: IF 669; Facesoffungi number: FoF 06223

Fig. 34

Saprobic or parasitic on leaves or the stem of wood moss (Hylocomiaceae) in terrestrial habitat. Sexual morph: Ascomata 111-225 $\mu \mathrm{m}$ high $\times 150-225 \mu \mathrm{m}$ diam. $(\bar{x}=115.6 \times 162 \mu \mathrm{m}, \mathrm{n}=$ 10), erumpent to completely superficial, solitary, spherical, globrous, dark brown to black, short papillate. Peridium wall 39-45 $\mu \mathrm{m}$ composed of 2 layers, an outer layer comprising small, heavily pigmented, thick-walled cells of textura angularis and an inner layer comprising lightly pigmented to hyaline, thin-walled cells of textura angularis. Hamathecium of dense, filamentous, branching, anastomosing, aseptate, hyaline pseudoparaphyses. Asci $115-130 \mu \mathrm{m} \times 13-17 \mu \mathrm{m}(\bar{x}=124.4 \times$ $15.1 \mu \mathrm{m}, \mathrm{n}=10$ ), 8-spored, cylindrical, with a short pedicel or sessile, rounded at the apex, with an ocular chamber, sometimes bulbous expanded below. Ascospores 35-45 $\mu \mathrm{m} \times 8-10 \mu \mathrm{m}(\bar{x}=38.4$ $\times 10.3 \mu \mathrm{m}, \mathrm{n}=10$ ), uniseriate, elongated ellipsoidal or rarely spindle, constricted at septa, 3-7 transversely septate, obtuse apex, sometimes narrow below, hyaline when immature to dark brown when mature, thick-walled, smooth. Asexual morph: Undetermined.

Material examined - AUSTRIA, Europe, Tirol on stem of wood moss Hylocomium splendens (Hedw.) W.P. Schimp. (Hylocomiaceae), 24 September 1973, P. Döbbeler (UME 30243).

Economic significance - The genus Bryorella contribute to the decomposition processes of mosses and hepatics. Bryorella acrogena has been reported to destroy the growing apices of single shoots in pleurocarpous mosses (Döbbeler 1978).

\section{Cerodothis Muthappa, Mycologia 61: 737 (1969)}

Saprobic on leaves. Sexual morph: Thyriothecia multilocular, pale yellow to brown, epiphyllous, sub-epidermal, comprises dark brown to brown cells of textura angularis (= cylindrical to cuboid cells). Locules globose to sub globose, ostiolate, with ectostroma bifurcate, endostroma rounded. Asci 8-spored, bitunicate, subcylindrical to clavate, sessile to very shortpedicellate, narrowly rounded at apex. Ascospores crowded, 2-3-seriate, 1-septate, narrowly obovoid to fusiform, hyaline, smooth-walled. Asexual morph: Undetermined.

Type species - Cerodothis aurea Muthappa

Notes - The monotypic genus Cerodothis was introduced by Muthappa in (1969) with Cerodothis aurea as the type species. The latter was isolated from leaves of Bambusa arundinacea in India. The asexual morph is unknown. We re-examined the holotype specimen of Cerodothis aurea from BPI under the code BPI 610067. The specimen is in poor condition and we could not observe many characters. The genus Cerodothis shares similar morphological characters to species of Microthyriaceae in having superficial, flattened, ascomata, with the cells of the upper wall radiating in parallel arrangement from the distinct central ostiolar opening, obclavate to cylindroclavate asci and 2-celled ascospores (Wu et al. 2011). However, we could not observe the asci and ascospores from the specimen. We therefore, treat this genus as doubtful and retain it in Dothideomycetes, genera incertae sedis. This fungus needs to be recollected and restudied.

Cerodothis aurea Muthappa, Mycologia 61: 737 (1969)

Fig. 35

Index Fungorum number: IF327982; Facesoffungi number: FoF 06673

Saprobic on leaves of Bambusa arundinacea. Sexual morph: Thyriothecia $500 \times 250 \mu \mathrm{m}$, multilocular, pale yellow to brown, epiphyllous, sub-epidermal, comprises dark brown to brown cells of texura angularis (= cylindrical to cuboid cells). Locules globose to subglobose, ostiolate, in transverse section, ectostroma bifurcate 40-76 $\mu \mathrm{m}$ diam., endostroma rounded, 102-178 $\mu \mathrm{m} \times$ 160-230 $\mu \mathrm{m}$; locules 34-76 $\mu \mathrm{m} \times 51-85 \mu \mathrm{m}$; ostiole 34-51 $\mu \mathrm{m}$ long. Asci 35-60 $\mu \mathrm{m} \times 8-10 \mu \mathrm{m}$, 8-spored, bitunicate, subcylindrical to clavate, sessile to very short-pedicellate, narrowly rounded at 
the apex. Ascospores 12-15 $\mu \mathrm{m} \times 3-4 \mu \mathrm{m}$, crowded, 2-3-seriate, 1-septate, narrowly obovoid to fusiform, hyaline, smooth-walled. Asexual morph: Undetermined.

Material examined - INDIA, Green Lands, Coorg, on leaves of Bambusa arundinacea (Poaceae), 10 March 1968, B.N. Muthappa (BPI 610067, holotype).

Economic significance - Members of the genus Cerodothis cause leaf spot by producing yellow microconidia on Bambusa bambos stands in Karnataka State (Muthappa 1969) and on Dendrocalamus strictus and Thyrsostachys siamensis stands in Kerala State (Mohanan 1994a, b).

Chaetosticta Petr. \& Syd., Annls mycol. 23(3/6): 270 (1925)

= Pyrenochaeta subgen. Trichocicinnus Sacc., Annls mycol. 3(6): 512 (1906) [1905]

= Trichocicinnus (Sacc.) Höhn., in Weese, Ber. dt.bot. Ges. 37: 159 (1919)

Endophytic or pathogenic on lower surface of living leaves of dicotyledon plants. Sexual morph: Undetermined. Asexual morph: Pycnidia superficial, loosely scattered, roundish to subglobose, papillate, black, sparingly clothed with straight, translucent olive brown continuous, bristle-like hairs of equal in length to the diameter of the conidiomata, more thickly set around the orifice, paler and more or less substellate-tufted below, easily removed from the host surface. Conidiophores branched, septate, compact, hyaline, cylindrical, tapered towards the apex, smoothwalled. Conidiogenous cells enteroblastic, phialidic, with minute collarette, discrete or integrated, cylindrical, tapered towards the apex. Conidia numerous, very dense, small, very variable from short oblong to oblong-elliptical, aseptate, hyaline, constricted at septa, truncate to pointed at base, light brown to olivaceous brown, thick and smooth-walled, with one to many oil droplets.

Type species - Chaetosticta perforata (Ellis \& Everh.) Petr. \& Syd.

Notes - The genus Chaetosticta was introduced by Petrak \& Sydow (1925) for the type species Chaetosticta perforata which was named as Chaetomella perforata isolated from living leaves of Cirsium discolor. Later, Chaetomella perforata was found to be an ascomycete by Ellis \& Everhart who renamed it as Venturia occidentalis (Sutton 1980). In another work, Saccardo transferred Venturia occidentalis to Acanthostigma occidentale (Ellis \& Ev.) Sacc (Lefebvre \& Stevenson 1945). In 1971, the genus Chaetosticta was redescribed by Crane (1971) and a lectotype was chosen. It was then transferred to Dothideomycetes, genera incertae sedis due to its uncertain morphological characters (Kirk et al. 2013, Wijayawardene et al. 2018). The sexual morph is unknown. Cultures and sequence data are unavailable. We re-examined the isotype specimen of Chaetosticta perforata from S herbarium under the code F49139. Morphological characters of Chaetosticta perforata are similar to Pyrenochaeta erysiphoides Sacc. In this study, we synonymise Chaetosticta perforata (三Chaetomella perforata Ellis \& Everh 1885) and Pyrenochaeta erysiphoides as all the three species share similar morphological characters and all of them were collected from the same hosts (Cirsium sp.). We believe that all these three fungi are the same but retain the genus Chaetosticta in Dothideomycetes, genera incertae sedis.

Chaetosticta perforata (Ellis \&Everh.) Petr. \& Syd., Annls mycol. 23(3/6): 270 (1925)

$\equiv$ Chaetomella perforata Ellis \& Everh., J. Mycol. 1(12): 153 (1885)

= Pyrenochaeta erysiphoides Sacc., Annls mycol. 3(6): 512 (1906) [1905]

Index Fungorum number: IF163090; Facesoffungi number: FoF 06227

Fig. 36

Endophytic or pathogenic on lower surface of living leaves of Cirsium arvense (Asteraceae). Sexual morph: Undetermined. Asexual morph: Pycnidia 135-173 $\mu \mathrm{m}$ high $\times 104-143$ $\mu \mathrm{m}$ diam $(\bar{x}=150.6 \times 121.8 \mu \mathrm{m}, \mathrm{n}=10)$, superficial, loosely scattered, roundish to subglobose, papillate, black, sparingly clothed with straight, translucent olive brown continuous, bristle-like hairs about equal in length to the diameter of the perithecia, more thickly set around the orifice, paler and more or less substellate-tufted below, easily removed from the host surface. Conidiophores branched, septate, compact, hyaline, cylindrical, tapered towards the apex, smooth. Conidiogenous cells 3-4 $\mu \mathrm{m}, 1.2-1.3 \mu \mathrm{m}(\bar{x}=3.8 \times 1.3 \mu \mathrm{m}, \mathrm{n}=10)$, enteroblastic, phialidic, with minute collarette, discrete or integrated, cylindrical, tapered towards the apex. Conidia 4.8-6.0 $\mu \mathrm{m}$ 
$\times 2.4-3.1 \mu \mathrm{m}(\bar{x}=5.4 \times 2.4 \mu \mathrm{m}, \mathrm{n}=10)$, numerous, dense, small, very variable from short oblong to oblong-elliptical, aseptate, hyaline, with one to many oil droplets, smooth-walled.

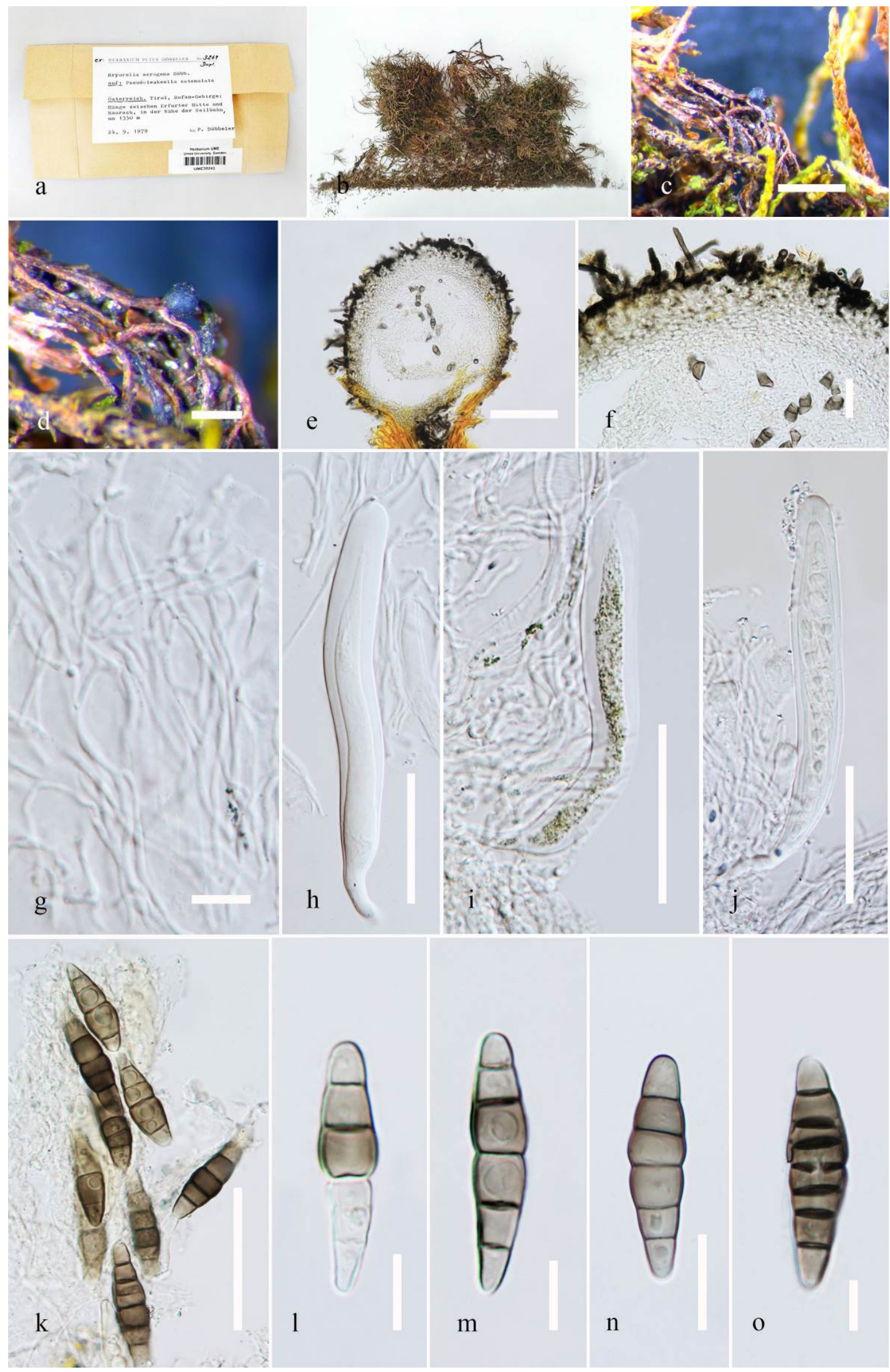

Figure 34 - Bryorella acrogena (UME 30243). a-d Herbarium specimen and habit on leaf. e Section of an ascoma. f Peridium g Hamathecium. h-k Asci. l-o Ascospores. Scale bars: c, d = 500 $\mu \mathrm{m}, \mathrm{e}=100 \mu \mathrm{m}, \mathrm{f}=20 \mu \mathrm{m}, \mathrm{g}, \mathrm{l}-\mathrm{o}=10 \mu \mathrm{m}, \mathrm{h}-\mathrm{k}=50 \mu \mathrm{m}$. 
Material examined - ITALY, Veneto, Selva (Treviso), on leaves of the living Cirsium arvense (Asteraceae), August 1905, P. A. Saccardo (S-F49139, isotype).

Economic significance - The genus Chaetosticta has been reported to cause zonate leafspot of Cowpea (Lefebvre \& Stevenson 1945). Chaetosticta cf. perforata also functions as mycorrhizae in some plants such as the orchids, especially Trichosalpinx orbicularis and Trigonidium egertonianum (Bayman \& Otero 2006).

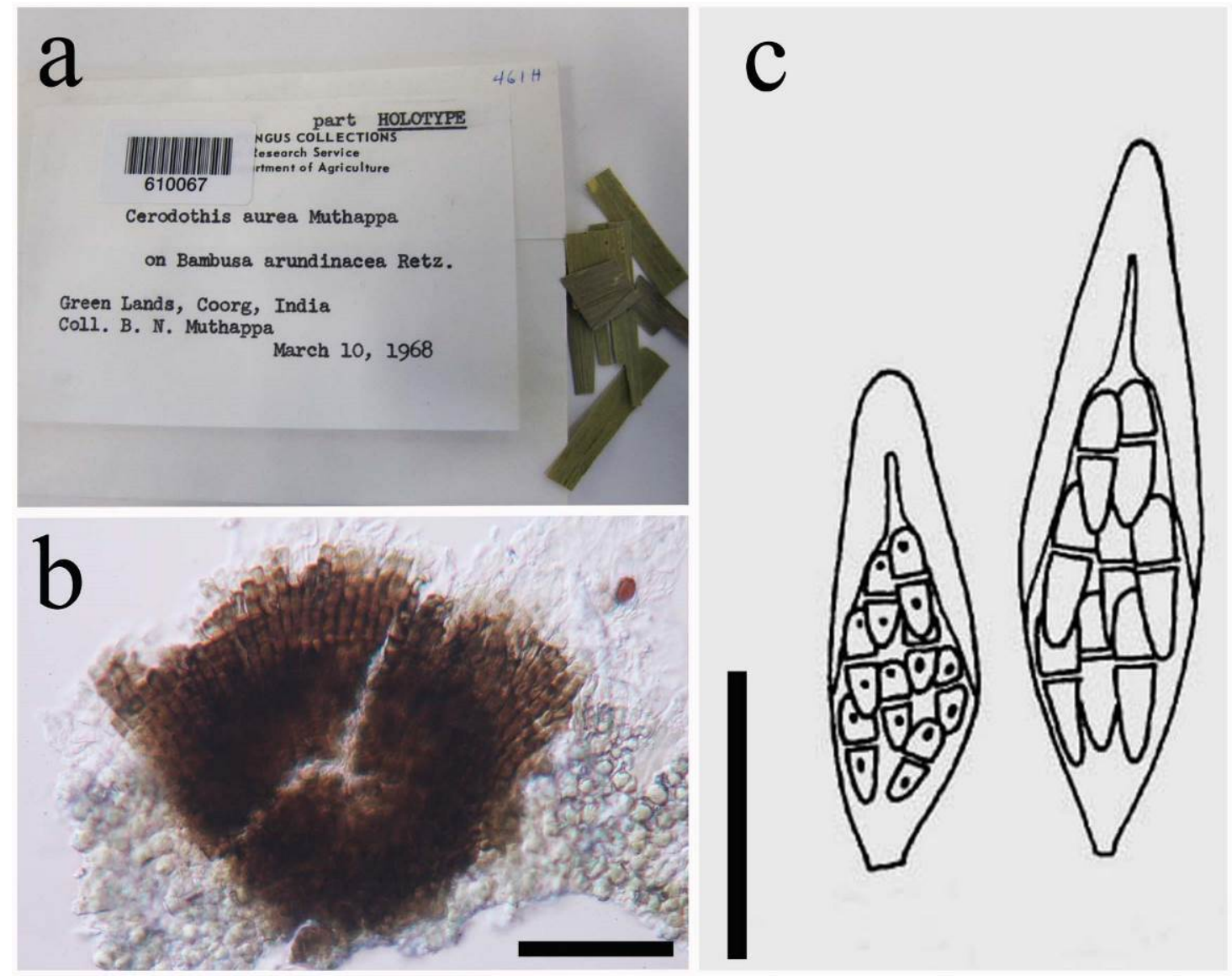

Figure 35 - Cerodothis aurea (BPI 610067, holotype). a Details of herbarium material. b Vertical section through ascoma. c Asci and ascospores (redrawn from Muthappa 1969). Scale bars: b $=50$ $\mu \mathrm{m}, \mathrm{c}=20 \mu \mathrm{m}$.

Chionomyces Deighton \& Piroz., Mycol. Pap. 128: 74 (1972)

Parasitic or epiphytic on the surface of living leaves. Sexual morph: Undetermined. Asexual morph: Colonies effuse, white, floccose. Mycelium hyperparasitic, consists of dark-brown to black, undulate, superficial, branched septate, thin and smooth-walled hyphae, thickly overgrowing superficial mycelium of leaf ascomycetes and bearing conidiophores as lateral branches. Conidiophores distributed singly or grouped onto loose fascicles, more or less erect, simple, colorless to pale brown, straight or flexuous with dense, refractive walls mainly towards the base, closely and markedly septate throughout or with the septa concentrated in the upper half, variable in length. Old conidial scars very slightly and evenly thickened. Conidiogenous cells holoblastic, percurrent, and sympodial. Conidia produced successively and holoblastically, one at a time from the tips of the conidiophores which proliferate percurrently by flipping the entire conidial scar to one side and growing through the opening to leave behind a series of pseudo-annellations, brown, fusiform, navicular or obclavate, attenuated towards the apex and often rostrate with a truncate unthickened hilum, 3 or more septate, smooth-walled. The conidia are firstly ovoid, then becoming elongate to produce a papillate apex. Mature conidia are spindle-shaped, colourless to brown, thin 
and smooth walled, 3-5 septate, with a wide truncate base and apical cell narrowing abruptly into beak-like projections, curved and wide at apex.

Type species - Chionomyces meliolicola (Cif.) Deighton \& Piroz.
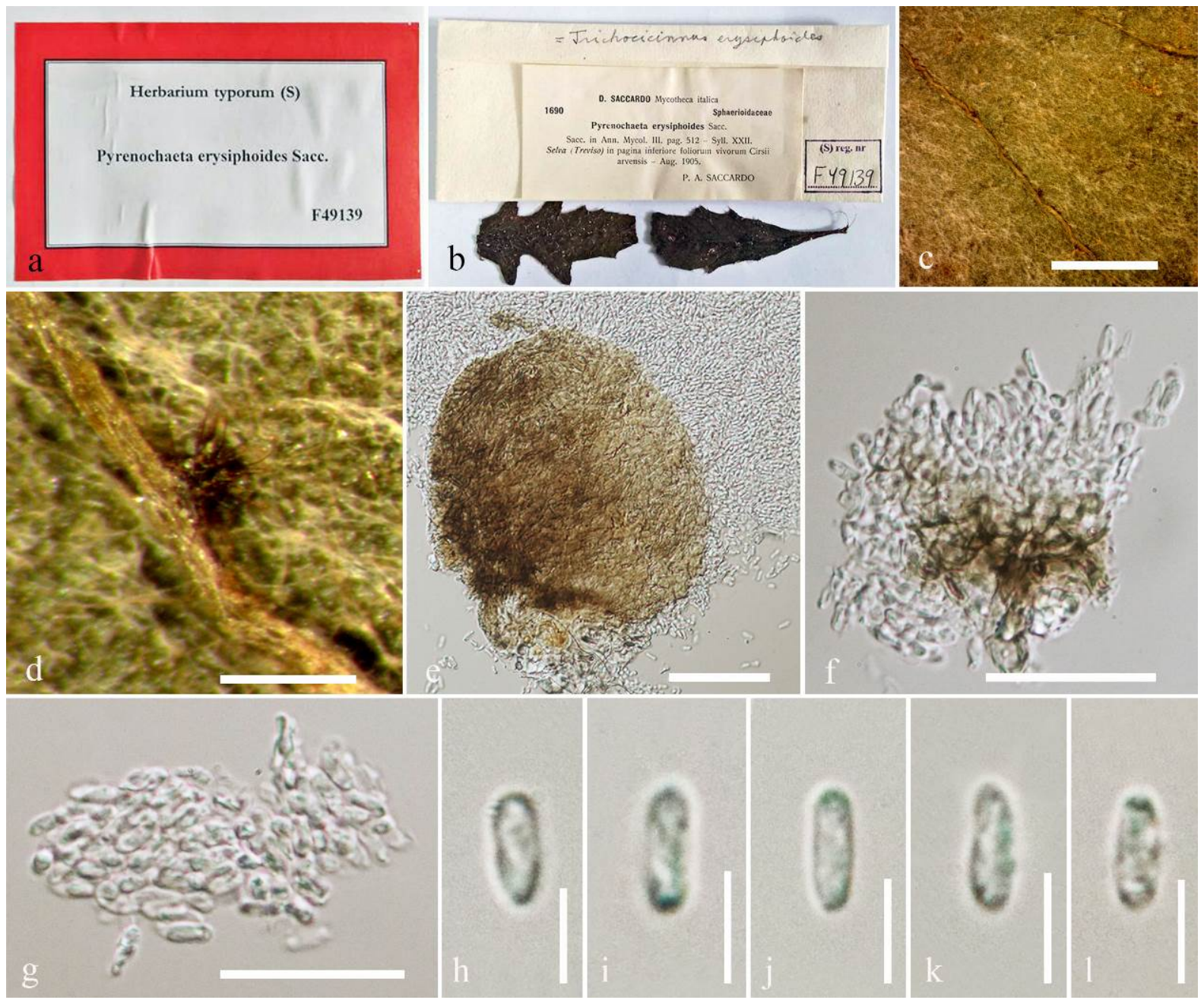

Figure 36 - Pyrenochaeta erysiphoides (S-F49139, isotype). a, b Details of herbarium material. c, $\mathrm{d}$ Habit and appearance of conidioma on host surface. e Squash mount of conidioma. $\mathrm{f}$ Conidiogenesis. g-l Conidia. Scale bars: $\mathrm{c}=500 \mu \mathrm{m}, \mathrm{d}=100 \mu \mathrm{m}, \mathrm{e}=50 \mu \mathrm{m}, \mathrm{f}, \mathrm{g}=30 \mu \mathrm{m}, \mathrm{h}-\mathrm{l}=5$ $\mu \mathrm{m}$.

Notes - The genus Chionomyces was introduced for C. meliolicola by Deighton and Pirozynski (1972). The genus Chionomyces can be found on Amazonia, Irenopsis and Meliola spp. in tropical East and West Africa and in the Dominican Republic. Its sexual morph is so far unknown. Morphological characters defining the genus Chionomyces include dark-brown to black undulate, branched, septate mycelium, holoblastic, percurrent and sympodial conidiogenous cells with brown and fusiform conidia. Currently, seven species are accommodated in the genus Chionomyces (Index Fungorum 2019). Chionomyces meliolicola is distinguished from other species in the genus by having wider conidia (mostly 8-10 $\mu \mathrm{m}$ wide) which are 3-5 septate. Chionomyces was reported as the anamorph of the genus Melioliphila Speg. (1924) however, whether this association is correct is unresolved because sequences and cultures are unavailable. The specimen of Chionomyces meliolicola, collected from leaves of Meliola seyboensis is described below from PDD herbarium. It is not the type material, but it is typical of the species. The genus Chionomyces can be compared to Metacapnodium accommodated in Metacapnodiaceae wherein asexual morph occurs on subiculum and comprise hyphae with broad, dark brown cells, and chains of globose, moniliform cells, with strong constrictions at the septa. Based on 
morphological study alone, we could not accommodate the genus Chionomyces in any family and hence we retain it in Dothideomycetes genera incertae sedis. Fresh specimens are required and molecular data are essential to recognize its correct placement in Ascomycota.

Chionomyces meliolicola (Cif.) Deighton \& Piroz., Mycol. Pap. 128: 75 (1972)

Fig. 37, 38

三 Monacrosporium meliolicola Cif., Annls mycol. 36(2/3): 244 (1938)

Index Fungorum number: IF 311046; Facesoffungi number: FoF 06228

Parasitic on the surface of living leaves. Sexual morph: Undetermined. Asexual morph: Colonies effuse, white, floccose. Mycelium hyperparasitic, consists of dark-brown to black undulate, branched septate, thin and smooth-walled hyphae 3-4 $\mu$ m wide, with thickly overgrowing superficial mycelium of leaf-inhabiting ascomycetes and bearing conidiophores as lateral branches. Conidiophores variable in length, up to $300 \mu \mathrm{m}$ long, distributed singly or grouped onto loose fascicles, more or less erect, simple, colorless to pale brown, straight or flexuous with dense, refractive walls mainly towards the base, closely and markedly septate throughout or with the septa concentrated in the upper half, of variable in length. Conidiogenous cells holoblastic, percurrent, sympodial. Conidia $11-17 \mu \mathrm{m} \times 3-5 \mu \mathrm{m}(\bar{x}=15.1 \times 4.7 \mu \mathrm{m}, \mathrm{n}=10)$ produced successively and holoblastically, one at a time from the tips of the conidiophores which proliferate percurrently by flipping the entire conidial scar to one side and growing through the opening to leave behind a series of pseudo-annellations. The conidia are firstly ovoid then elongate to produce a papillate apex. Mature conidia are spindle-shaped, colourless to brown, thin and smooth-walled, 3-5-septate, with a wide truncate base and apical cell narrowing abruptly into beak-like curved projections and wide at the apex.

Notes - The herbarium material from PDD revealed very broad conidiophore tips (about 4 $\mu \mathrm{m})$, broad conidial bases and apical cells extending into a long tail. The mostly 4-septate conidia measured 11-17 $\mu \mathrm{m} \times 3-5 \mu \mathrm{m}$. The original author had given conidial measurements as 8-10 $\mu \mathrm{m}$.

Material examined - NEW ZEALAND, Kauaeranga Valley, on unidentified leaves, 20 January 1974, J.M. Dingley (PDD 37163).

Economic significance - Species of the genus Chionomyces were identified as hyperparasitizing a Meliolales (one of the plant parasitic "black mildews") on an unidentified palm (Bronson 2018).

Chuppia Deighton, in Deighton \& Pirozynski, Mycol. Pap. 101: 32 (1965)

Saprobic or parasitic on leaves of solanaceous dicotyledonous plants. Sexual morph: Undetermined. Asexual morph: Hyphomycetous. Colonies effuse, dark brown to black. Mycelium superficial, densely aggregated composed of brown, branched, septate hyphae. Conidiophores micronematous, mammalliform, flexuous, irregularly branched, yellow brown to dark olive brown, smooth, arising separately as lateral protrusions of swollen intercalary hyphal cells. Conidiogenous cells holoblastic, integrated, terminal or intercalary, determinate, cylindrical, and denticulate, with conical denticies. Conidia solitary, pleurogenous, simple, ellipsoidal, irregular in shape, muriform, multicellular, formed separately as blown-out ends of the sporogenous cells which ruptures when the conidium is shed, constricted at the septa, with a basal protuberant hilum, dark yellow brown, smooth to verruculose-walled.

Type species - Chuppia sarcinifera Deighton

Notes - The monotypic genus Chuppia has been established by Deighton with $C$. sarcinifera Deighton as the type species (Matsushima 1975). The latter was isolated from leaves of Solanum lanugiflorum in Venezuela. Deighton (1965) placed the genus Chuppia in the family Dematiaceae of the order Hyphomycetales. The genus is characterized by effuse, dark brown to black colonies, superficial, densely aggregated mycelium composed of brown, branched, septate hyphae, micronematous, flexuous, irregularly branched conidiophores and muriform, sarciniform conidia with protuberant hilum. Currently, two species are accommodated in the genus Chuppia (Index Fungorum 2019). The sexual morph is unknown. Sequences and cultures are unavailable. We reexamined the holotype specimen from CUP herbarium under the code CUP-VZ-002114 and 
illustrate the morphological characters. In this study, we retain the genus Chuppia in Dothideomycetes genera incertae sedis. Fresh specimens and sequence data are required for this genus.
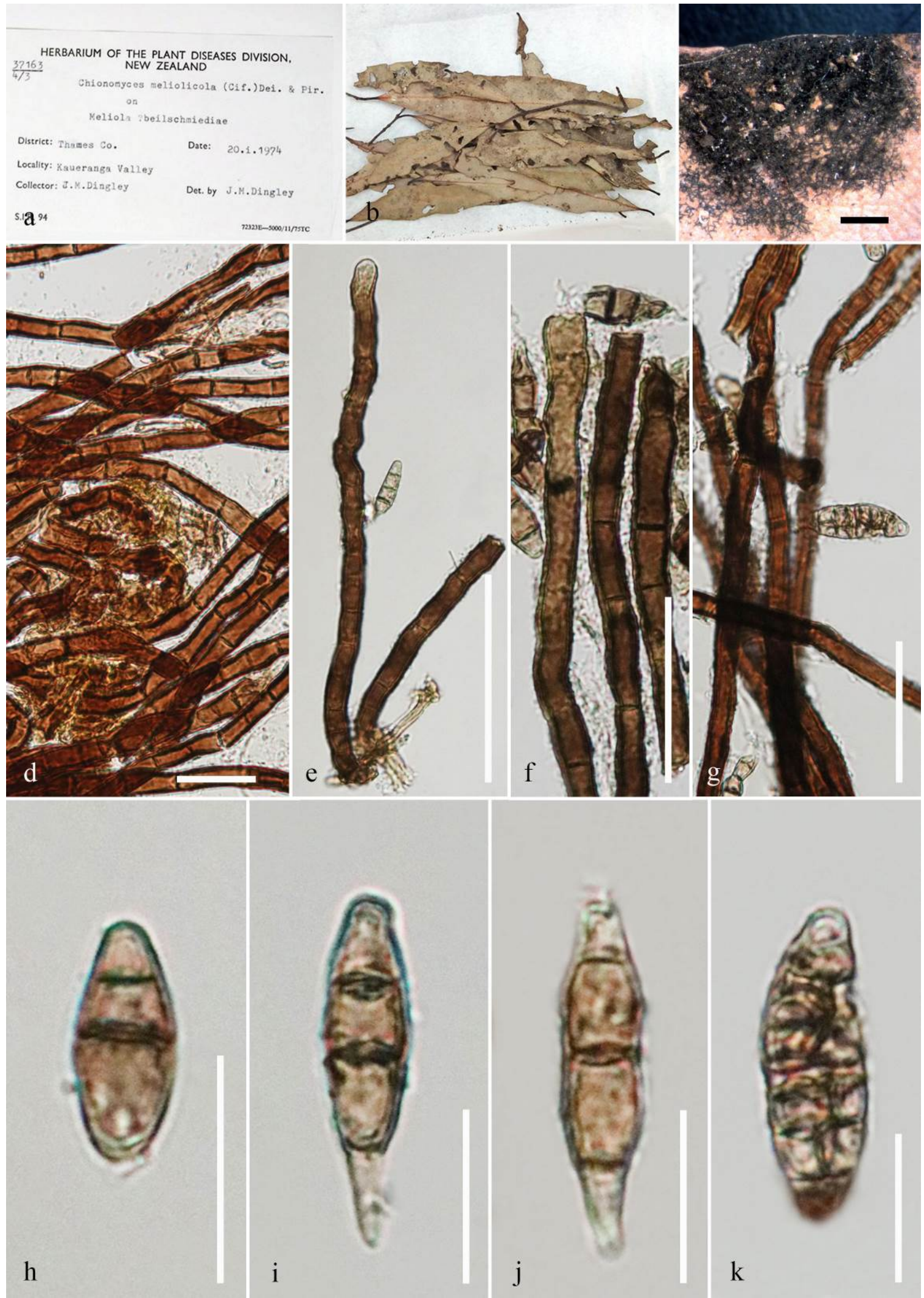

Figure 37 - Chionomyces meliolicola (PDD 37163). a, b Details of herbarium material. c Habit and appearance of ascomata on host surface. d Squash mount of mycelium. e-g Conidiophores. h, $\mathrm{k}$ Conidia. Scale bars: $\mathrm{c}=500 \mu \mathrm{m}, \mathrm{d}=10 \mu \mathrm{m}, \mathrm{e}=50 \mu \mathrm{m}, \mathrm{f}, \mathrm{g}=20 \mu \mathrm{m}, \mathrm{h}-\mathrm{k}=5 \mu \mathrm{m}$. 

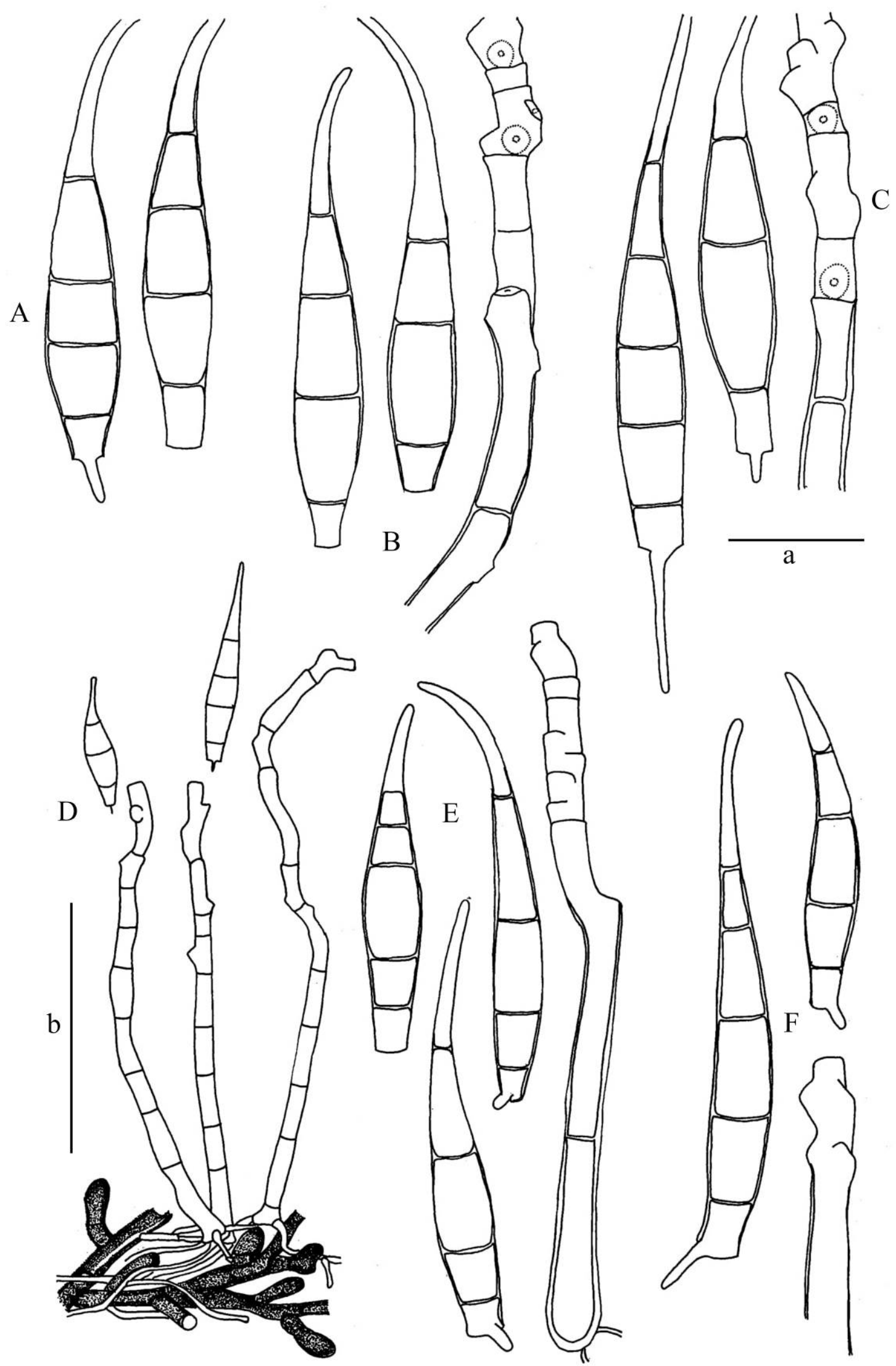

Figure 38 - Chionomyces meliolicola (redrawn from Deighton \& Pirozynski 1972). A, from the type of Monacrosporium meliolicola (597425b). B, from the type of Eriomycopsis meliolae (18399b). C, from 4705a. D, from 5194b. E, from 37651b. F, from the type of Eriomycopsis robusta (8808a). 
Index Fungorum number: IF328224; Facesoffungi number: FoF 06229

Saprobic or parasitic on leaves of Solanum lanugiflorum (Solanaceae). Sexual morph: Undetermined. Asexual morph: Hyphomycetous. Colonies epiphyllous, dark sooty brown, diskshaped, with indefinite margin, numerous, covering upper surface of the leaf, often with presence of dense masses of conidia covering the leaf hairs. Sometimes, small hypophyllous colonies are present. Mycelium superficial composed of brown, branched, septate hyphae around 3-5 $\mu \mathrm{m}$ wide, loosely packed over the leaf surface, closely verruculose. Conidiophores micronematous, abundant, irregularly branched, olive brown, smooth, arising as erect continuous protrusions from swollen intercalary node-cells, dark-brown in colour with mammalliform protrusions 3-6 $\mu \mathrm{m}$ long, often ellipsoidal with formation of single conidium at the apex. Conidiogenous cells holoblastic, integrated, determinate, doliiform, terminal or intercalary, denticulate, yellow brown. Conidia 12$38 \mu \mathrm{m} \times 19-35 \mu \mathrm{m}(\bar{x}=29.6 \times 25.8 \mu \mathrm{m}, \mathrm{n}=10)$ solitary, pleurogenous, initially continuous becoming ellipsoidal to irregular in shape, muriform, sarciniform, constricted at the septa with a protuberant hilum, dark brown, smooth.

Material examined - VENEZUELA, Miranda, Los Teques, Edo Miranda, on Solanum lanugiflorum Pitt. (Solanaceae), 11 March 1938, AS Muller (CUP-VZ-002114, holotype).

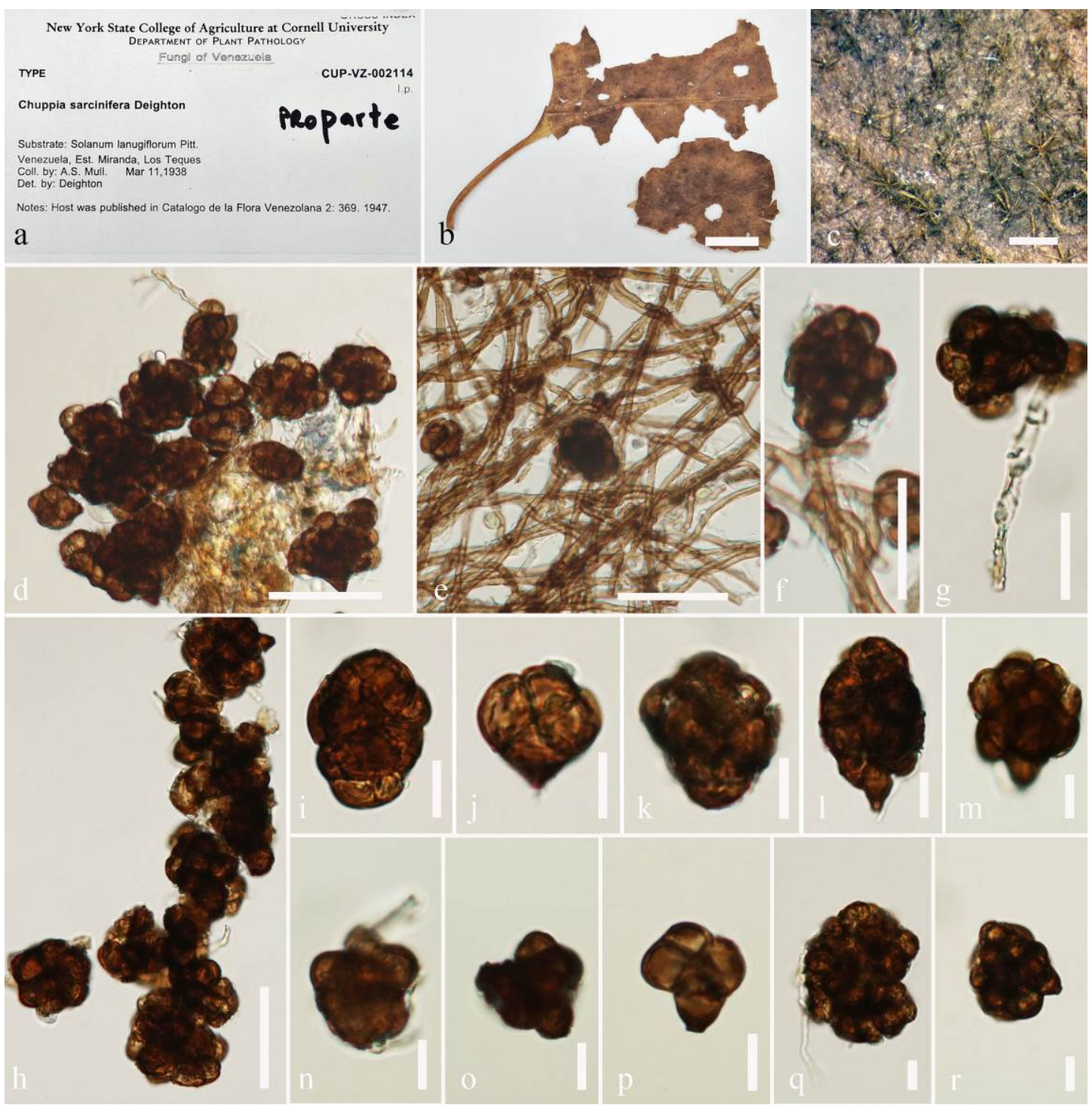

Figure 39 - Chuppia sarcinifera (CUP-VZ-002114, holotype). a, b Details of herbarium material. c Appearance of fungus on the host. $\mathrm{d}$, e Squash mount of mycelium. $\mathrm{f}$, g Conidiophores and conidia. 
h-r Conidia. Scale bars: $\mathrm{b}=500 \mu \mathrm{m}, \mathrm{c}=200 \mu \mathrm{m}, \mathrm{d}, \mathrm{e}=50 \mu \mathrm{m}, \mathrm{f}, \mathrm{g}=30 \mu \mathrm{m}, \mathrm{h}=20 \mu \mathrm{m}, \mathrm{i}-\mathrm{r}=10$ $\mu \mathrm{m}$.
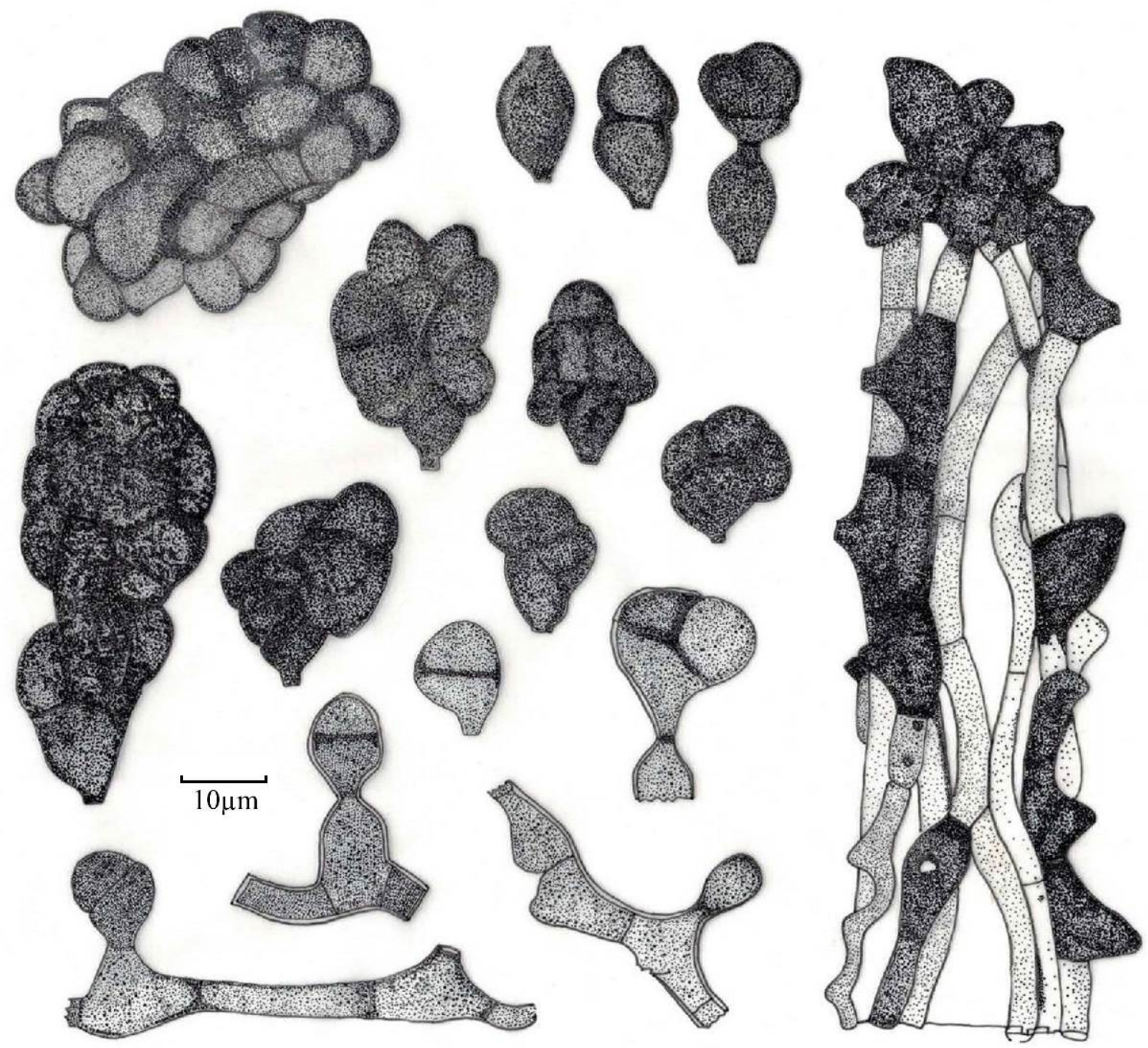

Figure 40 - Chuppia sarcinifera (redrawn from Deighton 1965). Scale bar: $\mathrm{x}=10 \mu \mathrm{m}$

Economic significance - Chuppia spp. have been reported to cause white angular leafspot, a disease of cucumber (Cucumis sativus L) (Vargas 1977). They are also responsible for degradation of para rubber leaf litter (Seephueak et al. 2010).

Coccodothis Theiss. \& Syd., Annls mycol. 12(3): 271 (1914)

Saprobic or parasitic on living leaves of Juniperus sp. Sexual morph: Ascostromata solitary, superficial to semi-immersed, epiphyllous, rarely hypophyllous semiorbicular to pulvinate, black. Peridium composed of isodiametric to polyhedric, dark brown, thick-walled cells. Presence of 3-4 loculi per ascostroma, separated from each other by a wall, composed of elongated, thick-walled, brown cells. Paraphyses hyaline, septate, becoming wider at their apices forming an epithecium. Asci bitunicate, fissitunicate, claviform, 8-spored with a distinct ocular chamber. Ascospores bi- to tri-seriate, 1-septate and constricted in their lower third, at first hyaline and covered by a mucous sheath, becoming brown with maturity, upper cell globose, lower cell nearly globose, wall smooth to slightly verrucose. Asexual morph: Undetermined.

Type species - Coccodothis sphaeroidea (Cooke) Theiss. \& Syd. 
Notes - The monotypic genus Coccodothis was introduced by Theissen \& Sydow (1914) for the type species Coccodothis sphaeroidea (= Dothidea sphaeroidea Cooke 1878). The characters of the genus are epiphyllous ascostromata, peridium of isodiametric thick walled cells of textura angularis, claviform, bitunicate, 8-spored asci and one-septate brown ascospores. Muller \& Sanwal (1954) placed the genus Coccodothis in the Patellariaceae, based on its similarity to the genus Karshchia Koerb. However, Coccodothis differs from this genus by its clearly formed hypostroma and a hymenium which is divided into several parts. Petrak (1954) included the genus in Polystomellaceae, whereas Muller \& von Arx (1962) suggested its inclusion in the Parmulariaceae based on its parasitic lifestyle. Hyde et al. (2013) excluded the genus Coccodothis from Parmulariaceae and accepted it as a genus in Dothideomycetes, genera incertae sedis (Wijayawardene et al. 2014). Cultures and sequences are unavailable. We re-studied the isotype specimen of Coccodothis sphaeroidea from S herbarium under the code S-F51270 and illustrate the morphological characters of the genus. The species lack sequence data. We therefore, retain the genus in Dothideomycetes, genera incertae sedis.

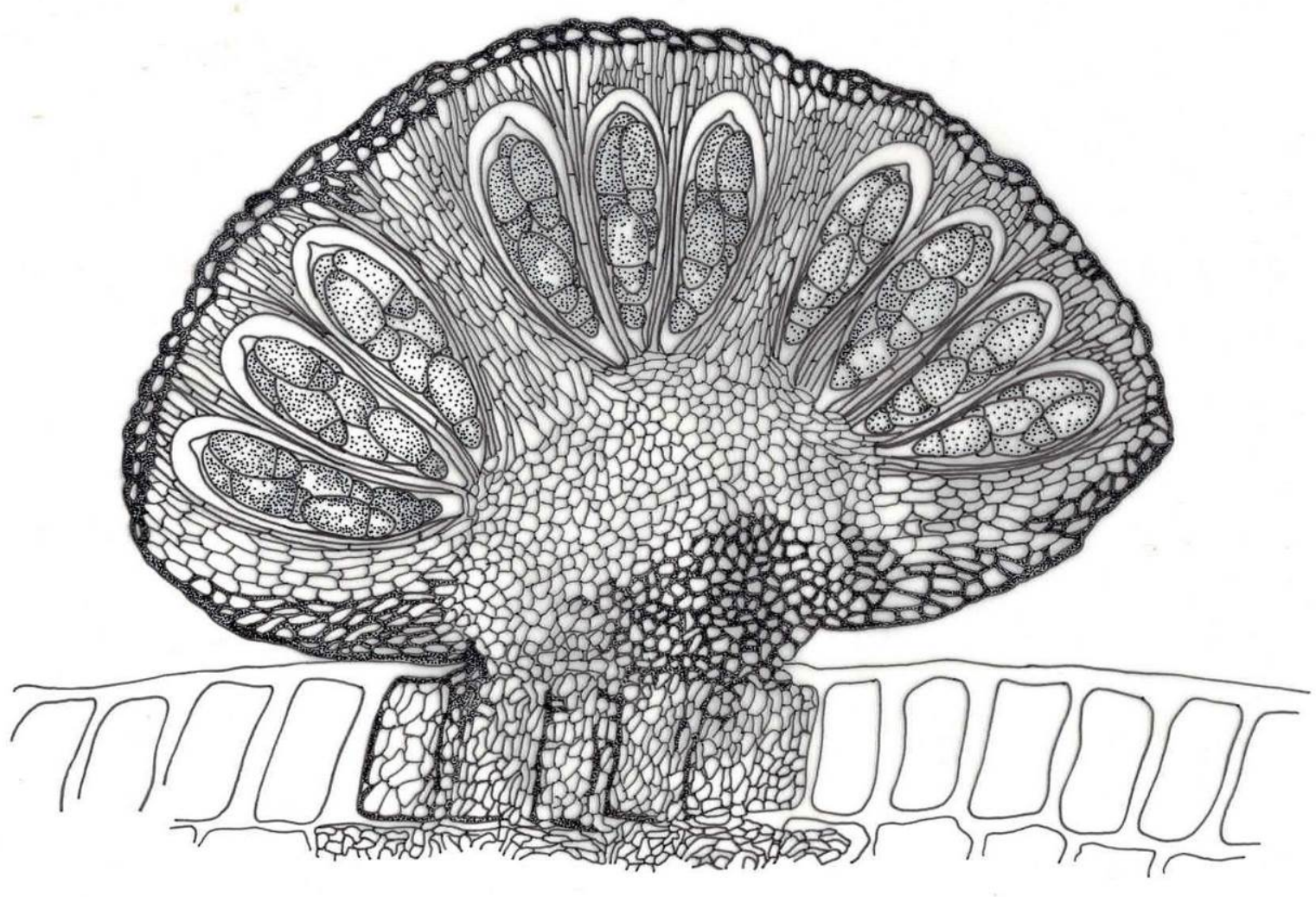

Figure 41 - Section through a stroma of Coccodothis sphaeroidea. (redrawn from Muller \& Sanwal 1954)

Coccodothis sphaeroidea (Cooke) Theiss. \& Syd., Annls mycol. 12(3): 271 (1914) $\quad$ Fig. 41, 42

$\equiv$ Dothidea sphaeroidea Cooke, Grevillea 7(no. 42): 50 (1878)

Index Fungorum number: IF 153862; Facesoffungi number: FoF 06230

Saprobic or parasitic on living leaves of Juniperus sp. Sexual morph: Ascostromata solitary, superficial to semi-immersed, epiphyllous, rarely hypophyllous, 70-102 $\mu \mathrm{m}$ high $\times 75-102 \mu \mathrm{m}$ diam., semiorbicular to pulvinate, black. Peridium 10-17 $\mu \mathrm{m}$, composed of isodiametric to polyhedric, dark brown, thick-walled cells of textura angularis, presence of 3-4 locules per ascostroma, separated from each other by a wall, 20-30 $\mu \mathrm{m}$ wide, composed of elongated, thickwalled, brown cells. Paraphyses 1-2 $\mu \mathrm{m}$ wide, becoming wider at their apices forming an epithecium, septate, hyaline. Asci 47-54 $\mu \mathrm{m} \times 23-25 \mu \mathrm{m}(\bar{x}=50 \times 25 \mu \mathrm{m}, \mathrm{n}=20)$ bitunicate, fissitunicate, claviform, 8-spored with a distinct ocular chamber. Ascospores 18-20 $\mu \mathrm{m} \times 8-10 \mu \mathrm{m}$ 
( $\bar{x}=19 \times 9 \mu \mathrm{m}, \mathrm{n}=20$ ), bi- to triseriate, 1-septate and constricted in their lower third, at first hyaline and covered by a mucous sheath, becoming brown with maturity, upper cell globose 9-13 $\mu \mathrm{m}$ diam., lower cell nearly globose 7-8 diam., wall smooth to slightly verrucose. Asexual morph: Undetermined.

Material examined - USA, Georgia, Darien, on living leaves of Juniperus sp. (Cupressaceae), 1993, H. W. Ravenel (S-F51270, isotype).

Economic significance - The genus Coccodothis comprises fungi which are parasitic on Juniperus species (Marmolejo et al. 1997).

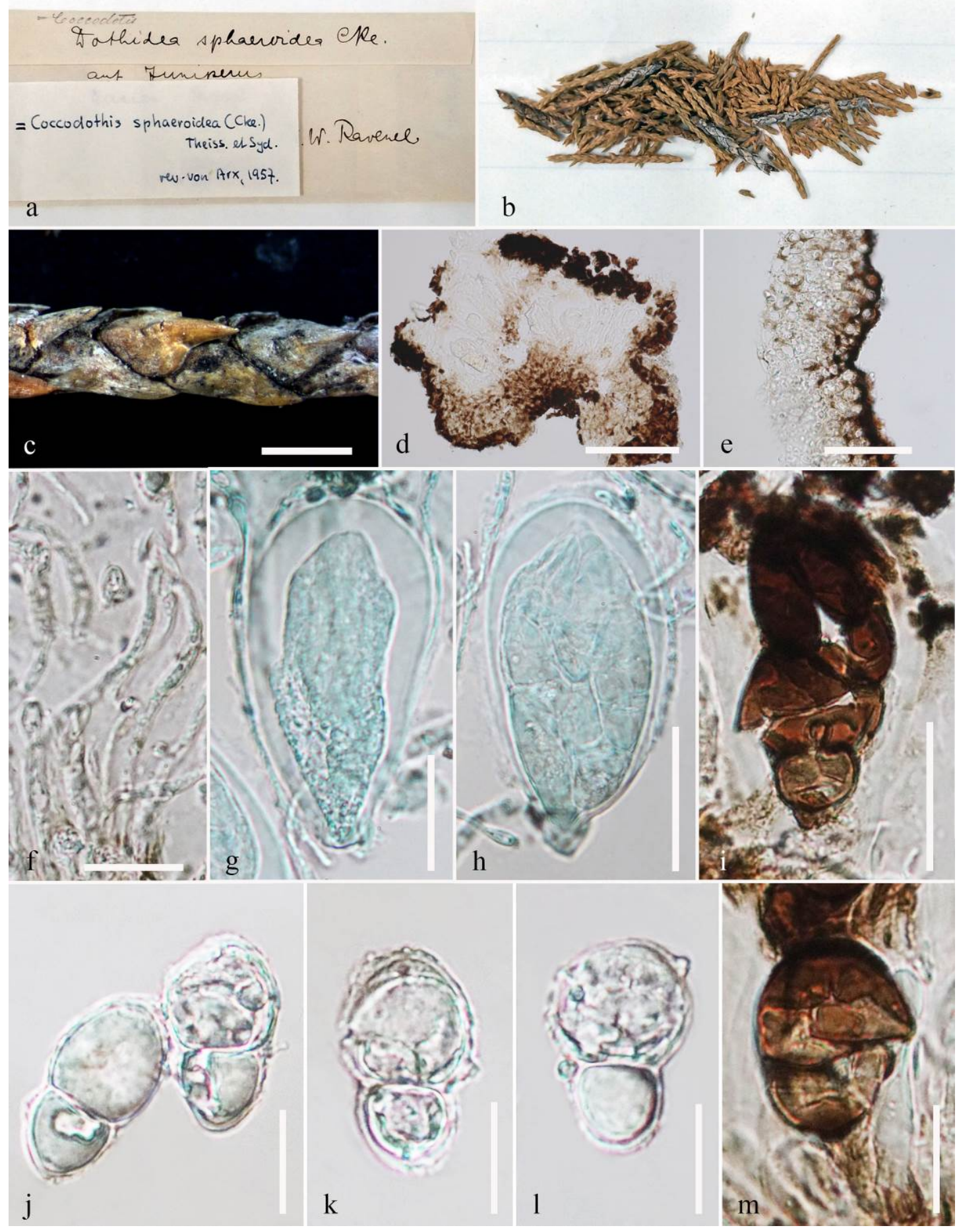

Figure 42 - Coccodothis sphaeroidea (S-F51270, isotype). a, b Details of herbarium material. c Appearance of ascomata on host surface. d Section of ascoma e Peridium. f Hamathecium. g-i Asci. j-m Ascospores. Scale bars: $c=500 \mu \mathrm{m}, \mathrm{d}=100 \mu \mathrm{m}, \mathrm{e}, \mathrm{g}-\mathrm{h}=20 \mu \mathrm{m}, \mathrm{f}, \mathrm{j}-\mathrm{m}=10 \mu \mathrm{m}$. 
Dermatodothis Racib. ex Theiss. \& Syd., Annls mycol. 12(3): 280 (1914)

Saprobic or parasitic on leaves of Symplocos sp. Sexual morph: Pseudothecia epiphyllous, scattered, solitary, or in small groups, gregarious, carbonaceous, subcuticular, hemispheric, postulate, more or less lenticular or conical, single or multiple to a flat, forming leaf spot, dark brown to black sometimes confluent, with superficial mycelial surrounding the pseudothecia. Peridium coriaceous, pseudoparanchymatous, thick-walled, dark-brown, thick in the upper part, becoming thicker towards the basal part of the lateral wall. Hypostroma subcuticular, composed of 1-2 layers of hyaline, palisadely arranged cells. Ascospores fusiform to elliptical, 2-septate, constricted at each septum, hyaline to pale brown. Asexual morph: Undetermined.

Type species - Dermatodothis javanica Racib.

Notes - The genus Dermatodothis was introduced by Raciborsky and afterwards described by Theissen \& Sydow $(1914,1915)$ with $D$. javanica as the type species. The genus is characterized by epiphyllous pseudothecia, elongate to ovoid, pale brown and 2-transversely septate ascospores. The asexual morph is unknown. Cultures and sequences are unavailable. According to Von Arx and Muller (1975), Dermatodothis belongs to Pleosporaceae in the vicinity of Leptosphaeria Ces. et De Not. However, the genus Dermatodothis differs from Leptosphaeria by the nature of its occurrence on living leaves, the very thick-walled, but relatively small cells of the peridium and by the stromata. We re-examined a specimen of Dermatodothis javanica from CUP herbarium under the code CUP-CH-001276 as the holotype specimen cannot be found. This genus could not be assigned to any family and a new family could not be introduced herein because all morphological characters could not be observed and sequence data are unavailable. We retain the genus in Dothideomycetes, genera incertae sedis. Further studies and new collections are required for this genus.

Dermatodothis javanica Racib., in Theissen \& Sydow, Annls mycol. 12(3): 280 (1914)

Figs 43, 44

Index Fungorum number: IF 153862; Facesoffungi number: FoF 06231

Saprobic or parasitic on leaves of Symplocos sp. Sexual morph: Pseudothecia 304-980 $\mu \mathrm{m}$ high $\times$ 283-969 $\mu \mathrm{m}$ diam., epiphyllous, scattered, solitary, or in small groups, gregarious, carbonaceous, subcuticular, hemispheric, postulate, more or less lenticular or conical, single or multiple to a flat, forming leaf spot, dark brown to black sometimes confluent, with superficial mycelial surrounding the pseudothecia. Peridium coriaceous, pseudoparanchymatous, thick-walled, dark-brown, thick in the upper part, becoming thicker towards the basal part of the lateral wall. Hypostroma subcuticular, composed of 1-2 layers of hyaline, palisadely arranged cells. Asci not observed. Ascospores 20-26 $\mu \mathrm{m} \times 3-5 \mu \mathrm{m}(\bar{x}=23.6 \times 4.2 \mu \mathrm{m}, \mathrm{n}=10)$, fusiform to elliptical, 3septate, constricted at the septa, hyaline to pale brown. Asexual morph: Undetermined.

Material examined - CHINA, Hainan, Ling-shui, on leaves of Symplocos sp (Symplocaceae), 25 May 1934, SQ Deng (CUP-CH-001276).

Notes - The asci of Dermatodothis javanica could not be observed from the herbarium specimen. We illustrate a drawing of the asci of Dermatodothis javanica as reported by Hsieh \& Chen (1993) and a section of the stroma as reported by Müller (1975). The ascospores as described by Hsieh and Chen (1993) are 2-septate, but the specimen we observed has 3-septate ascospores which are same as reported by Raciborsky (1914) and Müller (1975).

Economic significance - The genus Dermatodothis has been reported to be associated with hosts in the wet tropics of northern Queensland and causes dark-brown to black spots on hosts (Shivas \& Alcorn 1996).

Dianesea Inácio \& P.F. Cannon, Fungal Diversity 9: 72 (2002)

Saprobic on unidentified palm. Hemi-biotrophic as small leaf spots dispersed, rarely confluent, amphigenous, flat, black, variable in shape, generally elliptical, sometimes circular or irregular, forming dark brown to black leaf spots. Sexual morph: Ascostromata solitary, scattered, superficial to sometimes semi-immersed, conical, with single locule, ostiolate, coriaceous. Ostiole 
typically widely porate, broadly papillate. Peridium comprising several layers of brown and thickwalled cells of textura angularis. Hamathecium composed of 1-2 $\mu \mathrm{m}$ diam., of relatively thin, densely anastomosing, septate, branching, interascal pseudoparaphyses. Asci 8-spored, bitunicate, clavate to subcylindrical, with a short, narrow pedicel, thickened and rounded at the apex, with an ocular chamber. Ascospores uniseriate to partially overlapping, hyaline to pale olivaceous when immature, dark brown when mature, ellipsoidal or cylindrical to clavate, 1-septate, conspicuously constricted at the septum, smooth and thick-walled, surrounded by hyaline mucous sheath. Asexual morph: Coelomyceteous. Conidiomata variable in shape, pycnothyrial, subglobose to globose or elliptical, solitary, scattered, immersed to semi-immersed. Conidiophores indistinct. Conidiogenous cells holoblastic, enteroblastic, annellidic, cylindrical, and smooth. Conidia hyaline to greenish, cylindrical, straight or slightly curved, obtuse at apex, with small guttules.

Type species - Dianesea palmae (F. Stevens) Inácio \& P.F. Cannon

Notes - The monotypic genus Dianesea was introduced by Inácio \& Cannon (2002) for the type species Dianesea palmae which was previously known as Cocconia palmae. The latter was isolated from an unidentified palm in Costa Rica. The genus Dianesea is morphologically characterized by crustose, globose to subglobose ascostromata, clavate to subcylindrical 8-spored asci, ellipsoidal or cylindrical to clavate pale olivaceous 1-septate ascospores surrounded by hyaline mucous sheath. Cultures and sequences are unavailable. In this study, we re-examined the holotype specimen of Dianesea palmae (= Cocconia palmae). We observed both the sexual and asexual morphs. The sexual morph of the genus Dianesea resembles the genus Metameris (Botryosphaeriacae) except in spore morphology, particularly the narrow ascospores with a hyaline mucous sheath (Jayasiri et al. 2016). Species of Coccoidea Henn. resemble species of Dianesea, but the ascomata are formed as multiple distinct locules in peltate stromata, and the anamorph is acervular rather than locular (stromatic). The genus Coccoidea also has ascospores which are septate with septa close to the ends, in contrast to those of Dianesea where they have a \pm median septum (Eriksson, 1981, Barr 1987, Sivanesan 1987, Kirk et al. 2001). The genus Rosenscheldiella also resembles Dianesea with its external stromatal shape, however these contain multiple ascomatal locules which produce colourless ascospores, but lack a distinct periphysate ostiole (Barr 1987). We therefore retain the genus Dianesea in Dothideomycetes, genera incertae sedis.

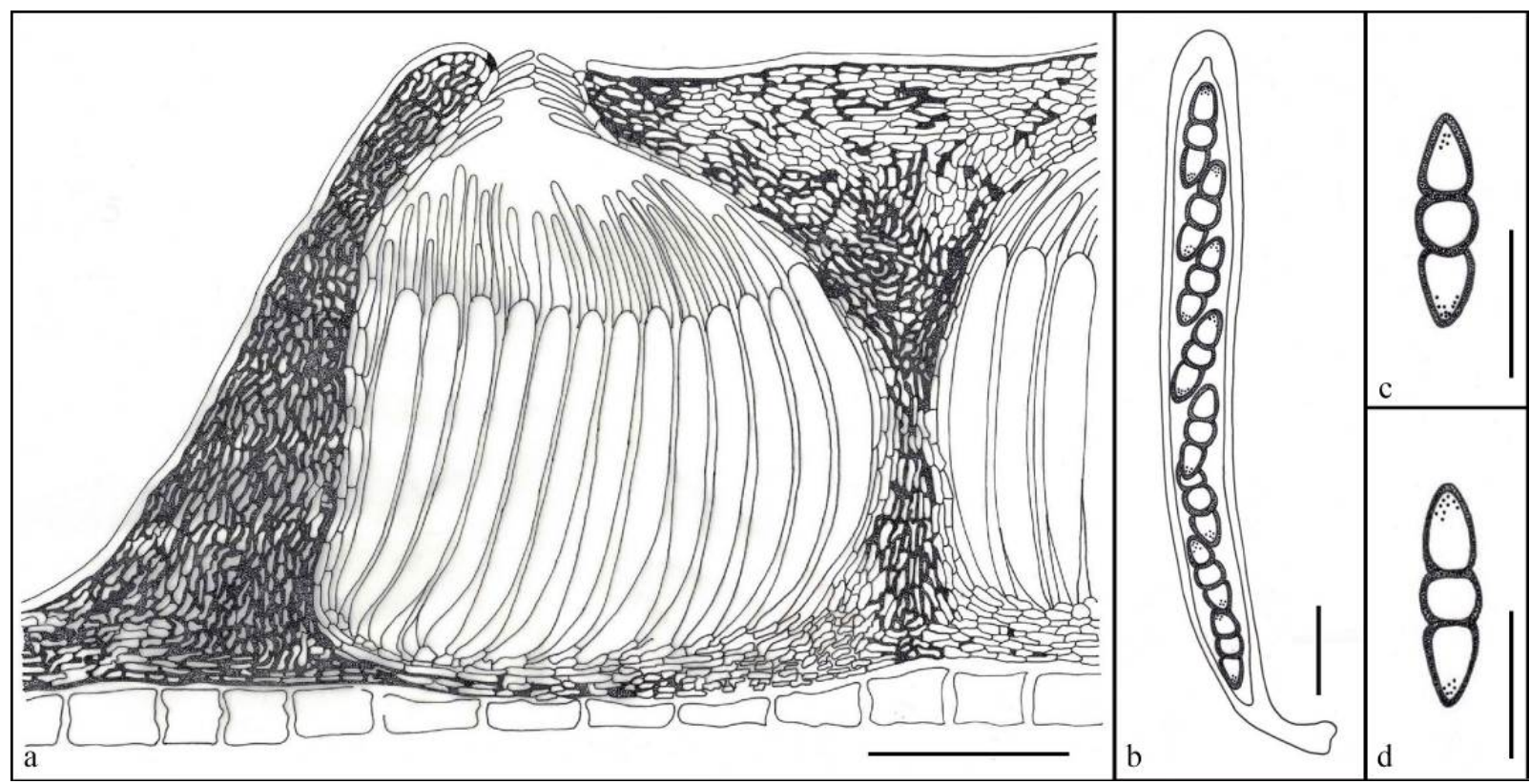

Figure 43 - A section through a stromal part of Dermatodothis javanica with two fruiting body cavities (redrawn from Müller (1975). b-d Asci and ascospores of Dermatodothis javanica (redrawn from Hsieh \& Chen 1993). Scale bar : $a=50 \mu \mathrm{m}, \mathrm{b}-\mathrm{d}=10 \mu \mathrm{m}$. 


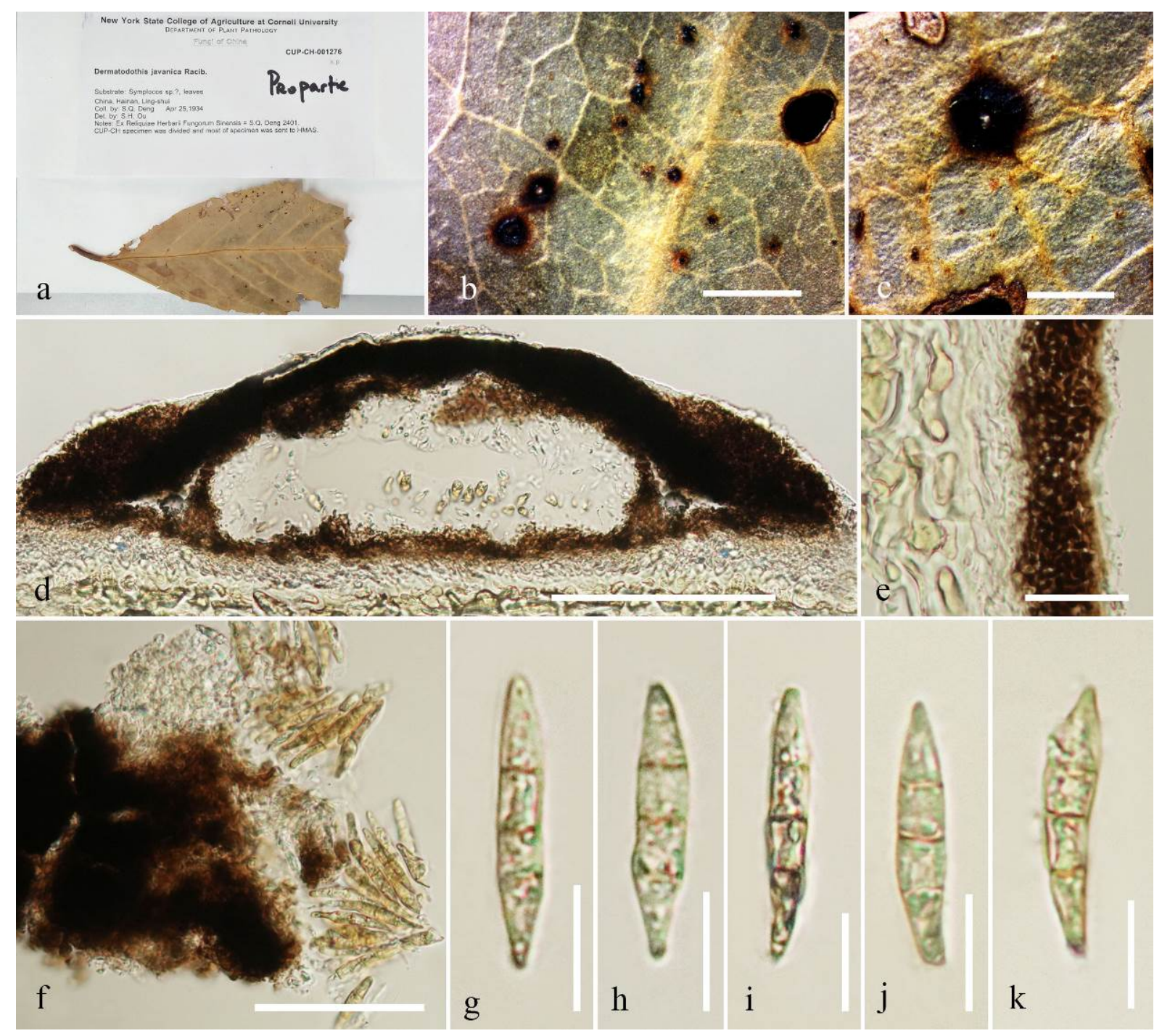

Figure 44 - Dermatodothis javanica (CUP-CH-001276). a Details of herbarium material. b, c Habit and appearance of ascomata on host surface. d Section of ascoma. e Peridium. f Squash mounts of ascoma. g-k Ascospores. Scale bars: $b=2 \mathrm{~mm}, \mathrm{c}=1 \mathrm{~mm}, \mathrm{~d}=100 \mu \mathrm{m}, \mathrm{e}=20 \mu \mathrm{m}, \mathrm{f}=$ $50 \mu \mathrm{m}, \mathrm{g}-\mathrm{k}=10 \mu \mathrm{m}$.

Dianesea palmae (F. Stevens) Inácio\& P.F. Cannon, Fungal Diversity 9: 72 (2002) ～Figs 45, 46 = Cocconia palmae F. Stevens, Illinois Biol. Monogr. (Urbana) 11(no. 2): 175 (1927)

Index Fungorum number: IF374776; Facesoffungi number: FoF 06232

Saprobic on palm stems. Hemi-biotrophic as small leaf spots $1 \mathrm{~mm}$ long $\times 2 \mathrm{~mm}$ wide, dispersed, rarely confluent, amphigenous, flat, black, variable in shape, generally elliptical, but sometimes circular or irregular forming dark brown to black leaf spots. Sexual morph: Ascostromata 1.6-2.2 mm high $\times 1.0-1.2 \mathrm{~mm}$ diam., solitary, scattered, superficial to sometimes semi-immersed, conical, with single locule, ostiolate, coriaceous. Ostiole typically widely porate, broadly papillate. Stromatal wall dense, thick, composed of brown-walled cells 3-7 $\mu \mathrm{m}$ diam, globose around the edge and angular and slightly larger in the central part. Peridium 24-41 $\mu$, comprising several layers of brown and thick-walled cells of textura angularis. Hamathecium composed of 1-2 $\mu \mathrm{m}$ diam., of relatively thin, dense, anastomosing, septate, branching interascal pseudoparaphyses. Asci 52-74 $\mu \mathrm{m} \times 13-16 \mu \mathrm{m}(\bar{x}=57.2 \times 14.8 \mu \mathrm{m}, \mathrm{n}=10), 8$-spored, bitunicate, clavate to subcylindrical, with a short, narrow pedicel, thickened and rounded at apex, with an ocular chamber. Ascospores $12-15 \mu \mathrm{m} \times 3-5 \mu \mathrm{m}(\bar{x}=13.8 \times 4.3 \mu \mathrm{m}, \mathrm{n}=10)$, uniseriate to partially overlapping, hyaline to pale olivaceous when immature, dark brown when mature, ellipsoidal or cylindrical to clavate, 1-septate, conspicuously constricted at the septum, smooth and 
thick-walled, surrounded by gelatinous layer, verrucose, cylindric, ellipsoidal, the lower cell slightly attenuated and rounded towards the base, the upper cell with a rounded apex. Asexual morph: Conidiomata 1.6-2.2 mm high $\times 1.0-1.2 \mathrm{~mm}$ diam., variable in shape, pycnothyrial, subglobose to globose or elliptical, solitary, scattered, immersed to semi-immersed. Conidiophores indistinct. Conidiogenous cells 3.3-5.5 $\mu \mathrm{m} \times 2.6-2.7 \mu \mathrm{m}(\bar{x}=4.4 \times 2.7 \mu \mathrm{m}, \mathrm{n}=10)$ holoblastic, annellidic, discrete, cylindrical, and smooth-walled. Conidia 11-13 $\mu \mathrm{m} \times 3-4 \mu \mathrm{m}(\bar{x}=12.7 \times 3.5$ $\mu \mathrm{m}, \mathrm{n}=10$ ) hyaline to greenish, cylindrical, straight or slightly curved, obtuse at the apex, with small guttules.

Material examined - COSTA RICA, Peralta, on palm leaves, 13 July 1923, F.L. Stevens (NY 01089812, holotype).

Economic significance - None is reported.
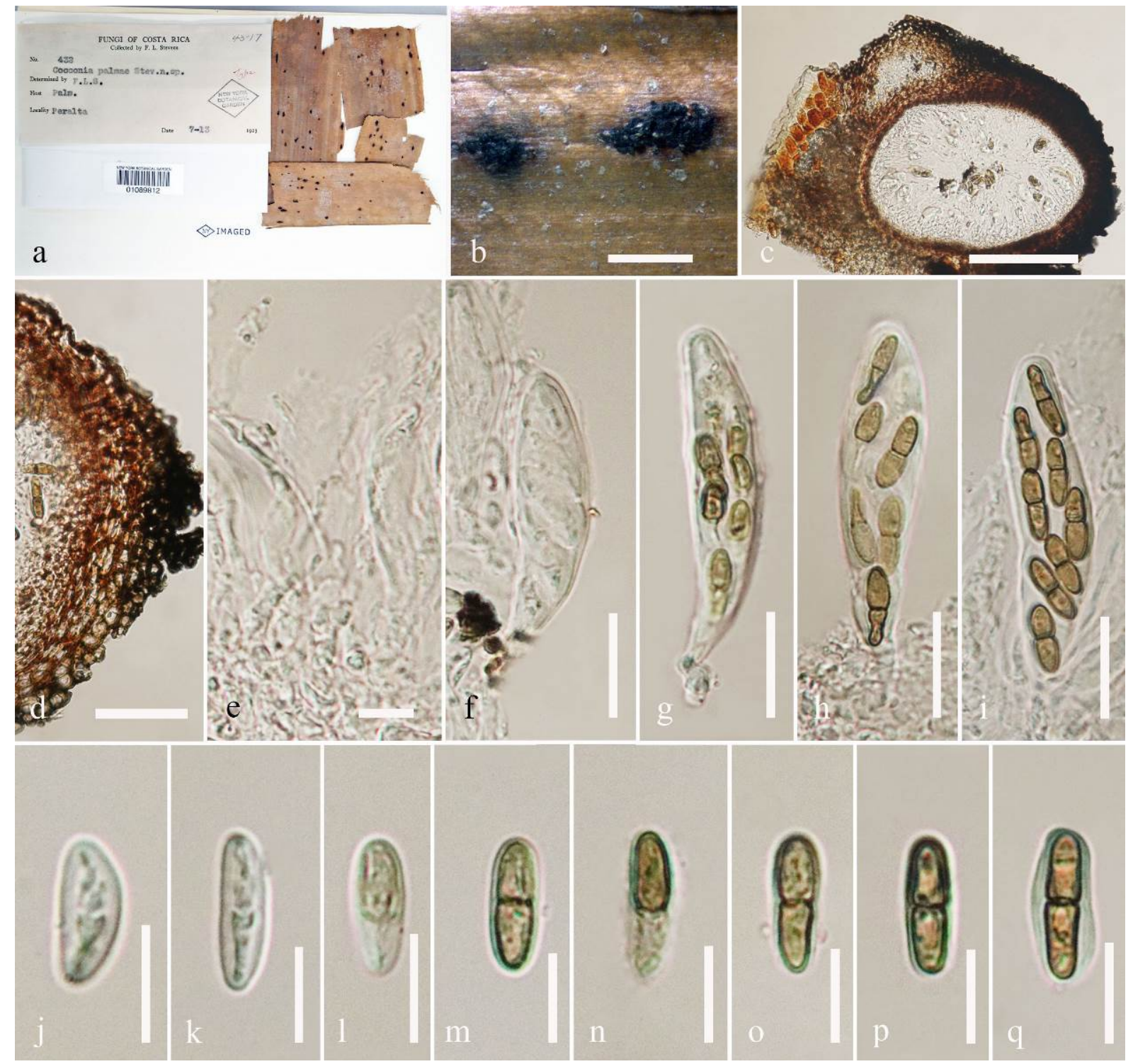

Figure 45 - Dianesea palmae; Sexual morph (NY 01089812, holotype). a Details of herbarium material. b Habit and appearance of ascomata on host surface. c Section of ascoma. d Peridium. e Hamathecium. f-i Asci. j-q Ascospores. Scale bars: $b=2 \mathrm{~mm}, \mathrm{c}=100 \mu \mathrm{m}, \mathrm{d}=30 \mu \mathrm{m}, \mathrm{e}, \mathrm{j}-\mathrm{q}=10$ $\mu \mathrm{m}, \mathrm{f}-\mathrm{i}=20 \mu \mathrm{m}$.

Didymocyrtidium Vain., Acta Soc. Fauna Flora fenn. 49(no. 2): 228 (1921)

Saprobic on growing stem of unidentified trees. Sexual morph: Ascomata semi immersed to superficial on host surface, simple, visible as dark brown to black circle on host surface. Peridium 
thick-walled, composed of several layers of dark-brown cells of textura angularis. Hamathecium present, with cellular, branching, pseudoparaphyses, anastomosing, branching, embedded in mucilaginous matrix, sometimes aparaphysate, covering asci by gelatinous matrix. Asci bitunicate, fissitunicate, 8-spored, ovoid to saccate, sessile with indistinct ocular chamber, thick-walled. Ascospores crowded, or irregularly arranged in the ascus, oblong or oval to ellipsoid, hyaline to subhyaline 1-septate, very slightly constricted at the septum, smooth or rough-walled. Asexual morph: Undetermined.

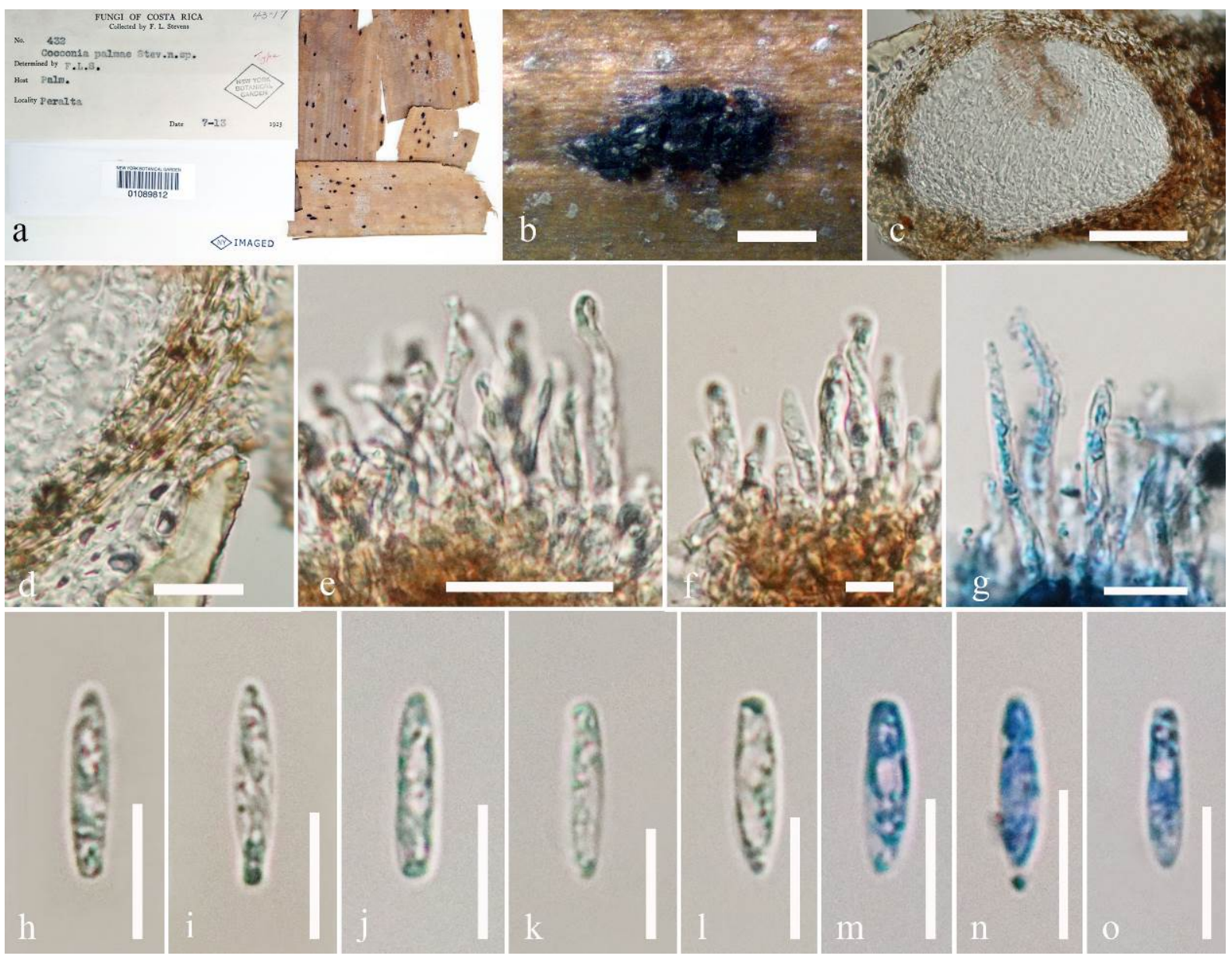

Figure 46 - Dianesea palmae; asexual morph (NY 01089812, holotype). a Details of herbarium material. b Habit and appearance of ascomata on host surface. c Section of conidioma. d Peridium. e-g Conidiogenesis $\mathrm{h}-\mathrm{o}$ Conidia. Note: $\mathrm{g}, \mathrm{m}-\mathrm{o}$ stained in lactophenol cotton blue. Scale bars: $\mathrm{b}=1$ $\mathrm{mm}, \mathrm{c}=50 \mu \mathrm{m}, \mathrm{d}, \mathrm{e}, \mathrm{g}-\mathrm{o}=10 \mu \mathrm{m}, \mathrm{f}=20 \mu \mathrm{m}$.

Type species - Didymocyrtidium nudum Vain.

Notes - The genus Didymocyrtidium was introduced by Vainio (1921) to accommodate three species namely Didymocyrtidium mozambicum Vain, Didymocyrtidium nudum and Didymocyrtidium populnellum. The major morphological characters of the genus are semiimmersed to superficial ascomata and unique subhyaline or pale greenish, 1-septate ascospores. The asexual morph is unknown. Cultures and sequences are unavailable. No type species was assigned to this genus. In the original description, the authors described Didymocyrtidium populnellum as a synonym of Mycoporum populnellum Nyl. However, according to index fungorum, Mycoporum populnellum is accommodated in its own family Mycoporaceae. We reexamined the holotype specimen of Didymocyrtidium populnellum (= Mycoporum populnellum) under the code F216647 from S herbarium. Upon examination of the specimen, we observed two fungi. One of them (Fig. 47) is characterised by semi-immersed to superficial simple, black ascomata on host surface with ovoid to saccate asci and hyaline to subhyaline 1-septate ascospores 
which match the description of Didymocyrtidium populnellum as given by Vainio (1921), while the other fungus (Fig. 48) is characterised by semi-immersed to superficial apothecia on its host surface, uni-loculate, forming pseudostroma or clypeus, 4-spored bitunicate asci with subhyaline or pale greenish, 3-4-septate ascospores which seems to be Mycoporum populnellum. The ascopores of Mycoporum populnellum were illustrated as 3-4-septate in a work by Millot (1899), while Nylander (1873) described the ascospores of M. populnellum as 1-septate. Hence, we cannot typify the genus Didymocyrtidium with the above specimen. We studied the syntype specimen of Didymocyrtidium nudum Vain. from $\mathrm{H}$ herbarium under the code H6022676 and illustrate the characters (Fig 42). Hence, in this study we typify the genus Didymocyrtidium with the type specimen Didymocyrtidium nudum. We also report that Didymocyrtidium populnellum and Mycoporum populnellum are two different taxa. We provide an updated illustration for Didymocyrtidium populnellum, Mycoporum populnellum and Didymocyrtidium nudum. We retain the genus Didymocyrtidium in Dothideomycetes, genera incertae sedis until sequence data becomes available.

Didymocyrtidium populnellum Vain., Acta Soc. Fauna Flora fenn. 49 (no. 2): 229 (1921)

Index Fungorum number: IF 384341; Facesoffungi number: FoF 06233

Saprobic on growing stems of unidentified trees. Sexual morph: Ascomata 10-35 $\mu \mathrm{m} \times 35$ $45 \mu \mathrm{m}(\bar{X}=35.2 \times 38.9 \mu \mathrm{m}, \mathrm{n}=10)$, semi-immersed to superficial on host surface, simple, visible as dark brown to black circle on host surface. Peridium thick-walled, composed of several layers of dark-brown cells of textura angularis. Hamathecium present, with cellular pseudoparaphyses, anastomosing, branching, embedded in mucilaginous matrix, sometimes aparaphysate, covering asci by gelatinous matrix. Asci $25-31 \mu \mathrm{m} \times 15-17 \mu \mathrm{m}(\bar{x}=28.4 \times 16.4 \mu \mathrm{m}, \mathrm{n}=10)$, bitunicate, fissitunicate, 8-spored, ovoid to saccate, sessile with indistinct ocular chamber, thick-walled. Ascospores 9-10 $\mu \mathrm{m} \times 3-4 \mu \mathrm{m}(\bar{x}=9.2 \times 3.9 \mu \mathrm{m}, \mathrm{n}=10)$, bi-to tri-seriate, or crowded, oval to ellipsoid, hyaline to subhyaline 1-septate, very slightly constricted at the septum, smooth or roughwalled. Asexual morph: Undetermined.

Material examined - FINLAND, Etelä-Häme, Tavastia, Asikkala, on stems of unidentified trees, June 1892, J.P. Norrlin (1866) (S-F216647, holotype).

Economic significance - None is reported.

Didymocyrtidium nudum Vain., Acta Soc. Fauna Flora fenn. 49(no. 2): 229 (1921)

Fig. 49

Index Fungorum number: IF 557075; Facesoffungi number: FoF 07131

Saprobic on growing stems of Betula sp. Sexual morph: Ascomata 29-40 $\mu \mathrm{m}$ high $\times$ 36-43 $\mu \mathrm{m}$ diam., $(\bar{x}=38.2 \times 39.9 \mu \mathrm{m}, \mathrm{n}=10)$, semi immersed to superficial on host surface, simple, visible as dark brown to black circle on host surface. Peridium 9-11 $\mu$ m wide thick-walled, composed of several layers of dark-brown cells of textura angularis. Hamathecium 2-3 $\mu \mathrm{m}$ wide present, with cellular pseudoparaphyses, anastomosing, branching, embedded in mucilaginous matrix, sometimes aparaphysate, covering asci by gelatinous matrix. Asci 30-32 $\mu \mathrm{m} \times 16-18 \mu \mathrm{m}$ $(\bar{x}=31.4 \times 17.4 \mu \mathrm{m}, \mathrm{n}=10)$, bitunicate, fissitunicate, 8-spored, ovoid to saccate, sessile with indistinct ocular chamber, thick-walled. Ascospores 10-12 $\mu \mathrm{m} \times 3-4 \mu \mathrm{m}(\bar{x}=11.5 \times 3.9 \mu \mathrm{m}, \mathrm{n}=$ 10), bi-to tri-seriated, or overlapping, oblong to cylindrical or ellipsoid, hyaline to subhyaline 1septate, very slightly constricted at the septum, smooth or rough-walled. Asexual morph: Undetermined.

Material examined - RUSSIA, on stems of Betula sp. (Betulaceae), 16 July 1928, E. Häyrén (H6022676, syntype)

Economic significance - None is reported.

Dothichiza Lib. ex Roum., Fungi Selecti Galliaei Exs.: no. 627 (1880)

Pathogenic on various substrates of a range of host plants. Sexual morph: Undetermined. Asexual morph: Conidiomata numerous in the bark, stromatic, initially in pustules covered by 
epidermis of the host, rupturing at the top when mature, immersed to sub-peridermal, solitary, multilocular and convoluted, often irregular in shape, dark brown to black, ostiolate. Conidiomata wall 11.2-26.6 $\mu \mathrm{m}$ wide with irregular surface at the base on the inside,outer layer composed of 23 layers of brown cells of textura angularis, inner layer composed of hyaline-walled cells of textura angularis. Conidiophores hyaline, branched at the base, septate, smooth, hyaline. Conidiogenous cells enteroblastic, phialidic, cylindrical, indeterminate, integrated or discrete, hyaline, smooth. Conidia cylindrical, subglobose to ovoid, or rarely ellipsoid, obtuse at apex, truncate or rounded at base, aseptate, creamy to tanny olive or pale brown, median guttulate, thick and smooth-walled.

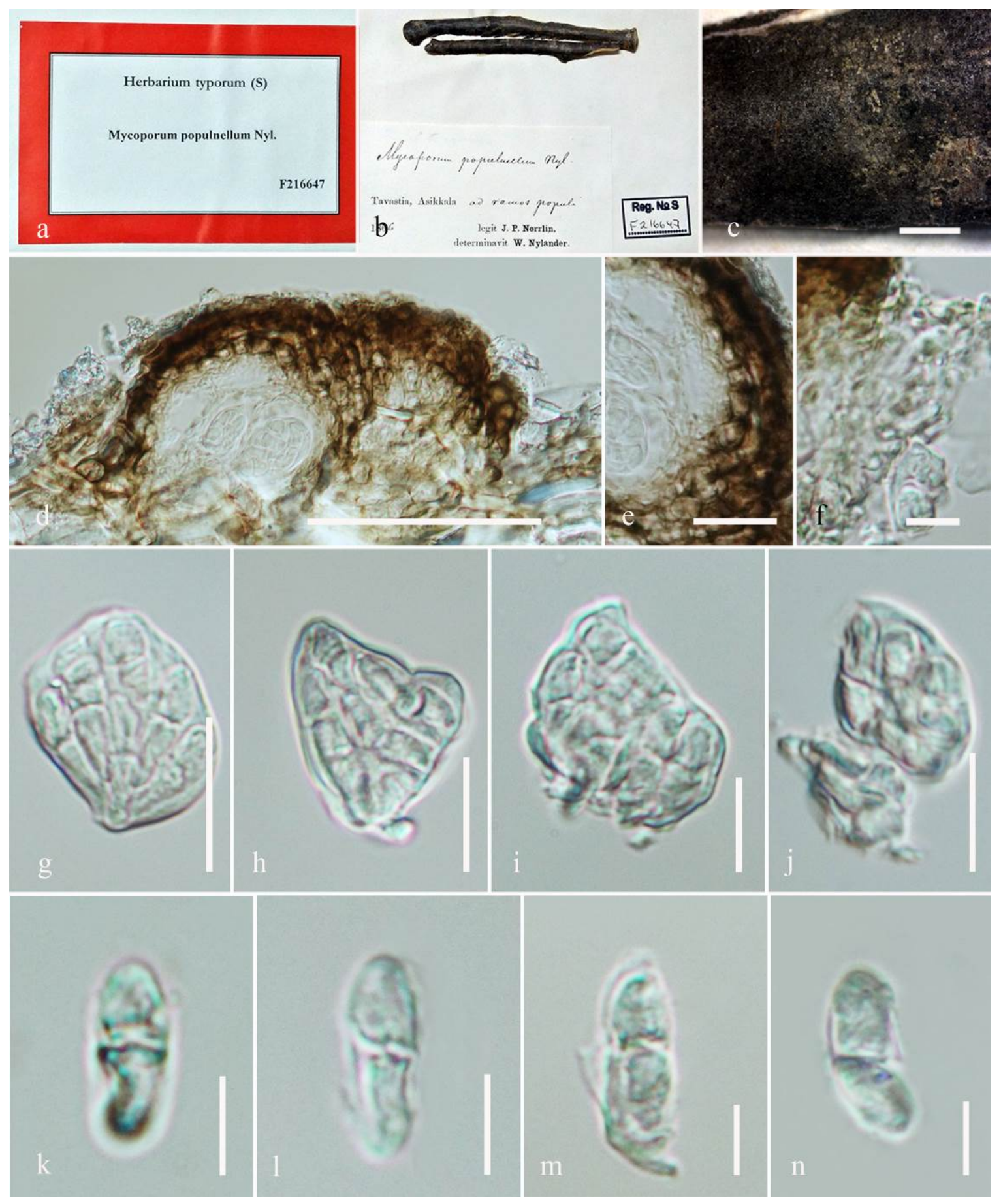

Figure 47 - Didymocyrtidium populnellum (S-F216647, holotype). a Details of herbarium material. $\mathrm{b}$, c Habit and appearance of ascomata on host surface. d Section of ascoma. e Peridium. $\mathrm{f}$ Hamathecium. g-j Asci. $k-n$ Ascospores. Scale bars: $c=2 \mathrm{~mm}, \mathrm{~d}=50 \mu \mathrm{m}, \mathrm{e}-\mathrm{j}=10 \mu \mathrm{m}, \mathrm{k}-\mathrm{n}=5$ $\mu \mathrm{m}$. 

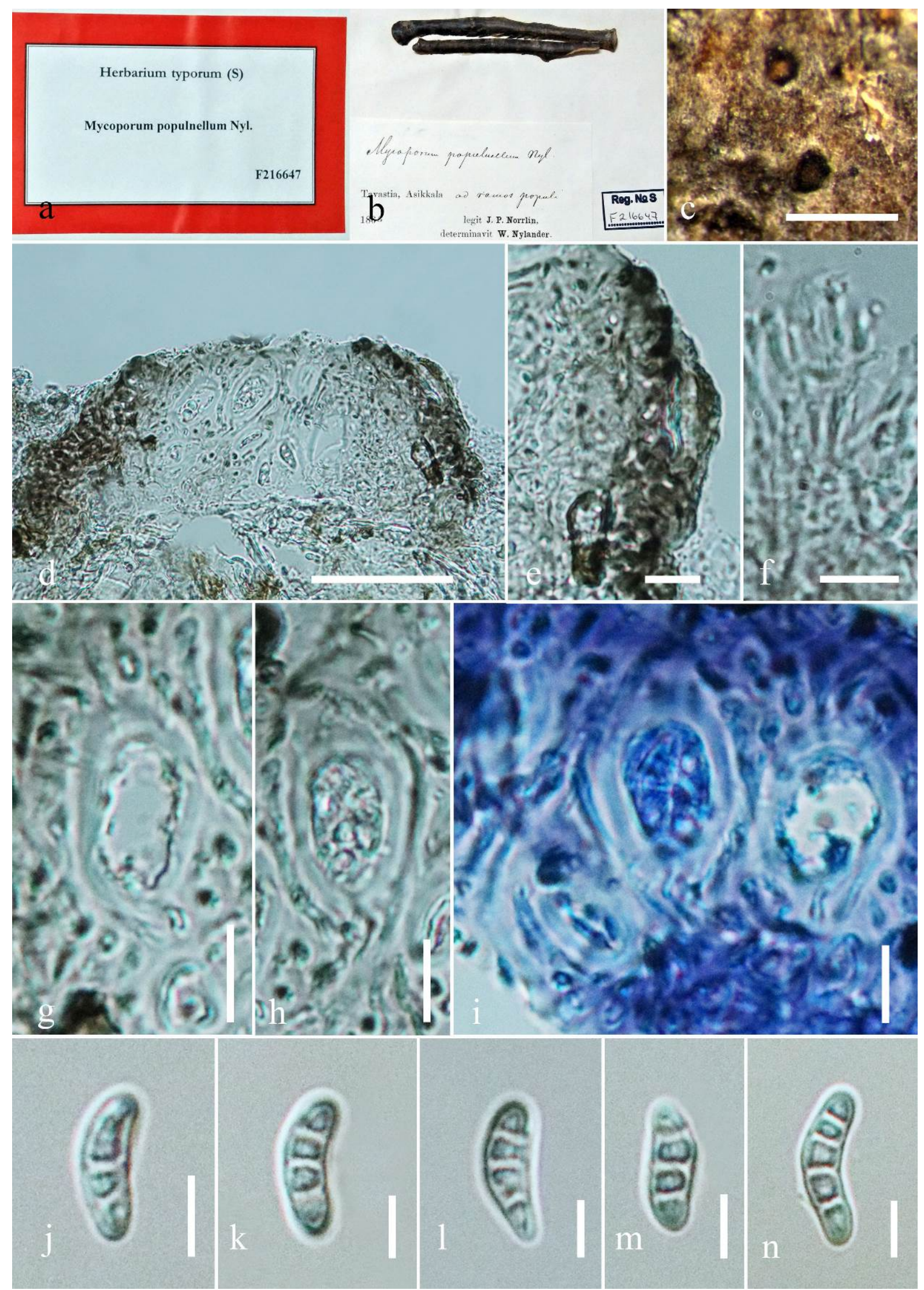

Figure 48 - Mycoporum populnellum (S-F216647, holotype). a Details of herbarium material. b, c Habit and appearance of ascomata on host surface. d Section of ascoma. e Peridium. $f$ Hamathecium. g-i Asci. j-n Ascospores. Scale bars: $b=2 \mathrm{~mm}, \mathrm{c}=1 \mathrm{~mm}, \mathrm{~d}=50 \mu \mathrm{m}, \mathrm{e}-\mathrm{i}=10 \mu \mathrm{m}$, $\mathrm{f}, \mathrm{j}-\mathrm{n}=5 \mu \mathrm{m}$. 


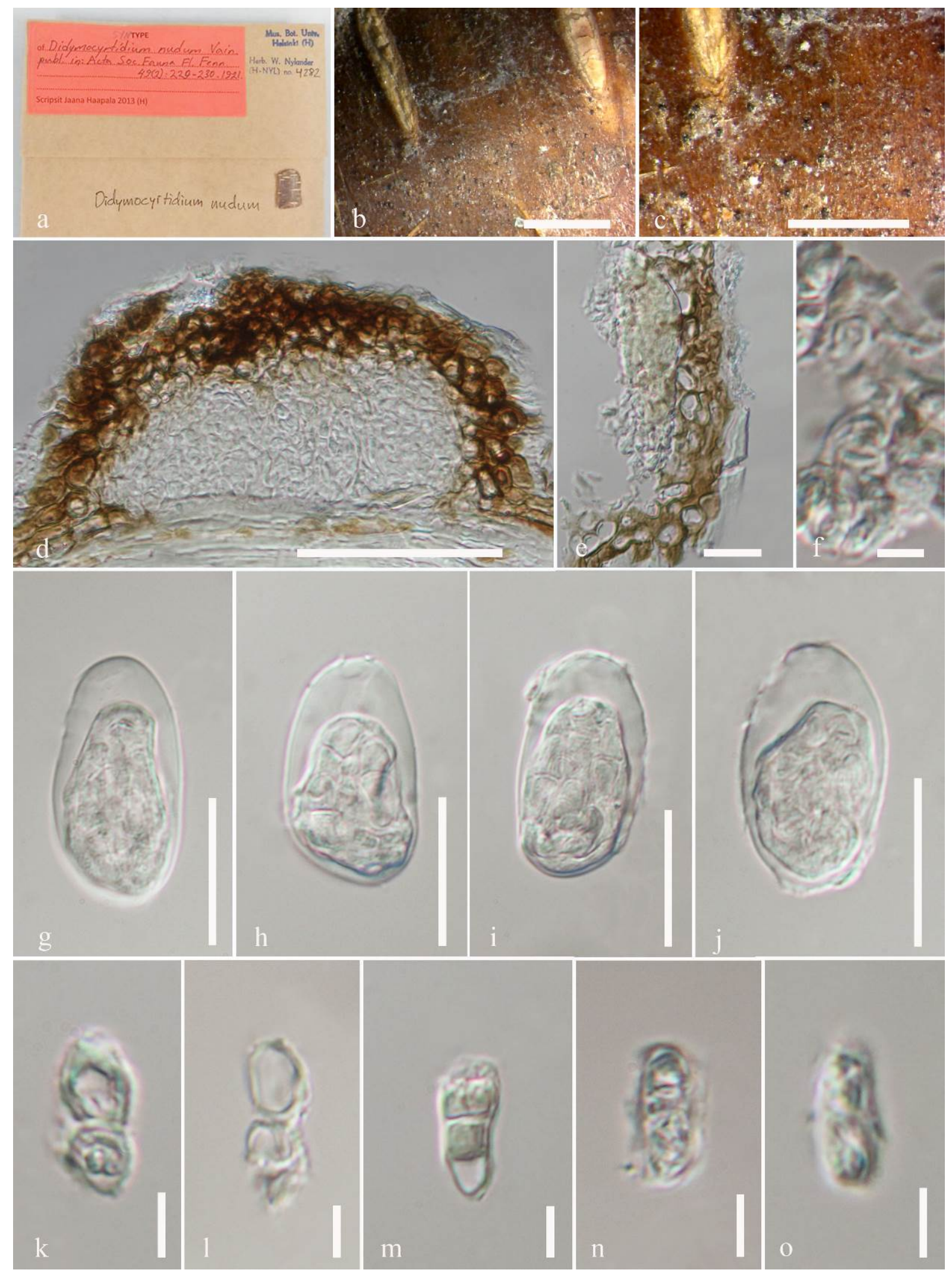

Figure 49 - Didymocyrtidium nudum (H6022676, syntype). a Details of herbarium material. b, c Habit and appearance of ascomata on host surface. d Section of ascoma. e Peridium. $f$ Hamathecium g-j Asci k-o Ascospores. Scale bars: b, $c=500 \mu \mathrm{m}, \mathrm{d}=50 \mu \mathrm{m}, \mathrm{e}=10 \mu \mathrm{m}, \mathrm{f}, \mathrm{k}-\mathrm{o}=$ $5 \mu \mathrm{m}, \mathrm{g}-\mathrm{j}=20 \mu \mathrm{m}$.

Type species - Dothichiza populea Sacc. \& Briard

Notes - The genus Dothichiza was introduced by Libert \& Roumegère (1880) for the type 
species D. populea, isolated from dead branches of Populus sp. Dothichiza populea was initially described and named in Saccardo \& Briard (1884) who reported the fungus as a saprobe on dead branches of Populus at Troyes, France. The genus is characterized by numerous convoluted conidiomata, firstly in pustules, covered by the epidermis of the host, later rupturing at the top when mature and cylindrical, subglobose to ovoid conidia. Currently, 15 epithets are accommodated under the genus Dothichiza (Index Fungorum 2019). There is no report of a sexual morph. The genus Dothichiza shares morphological similarities to Cyclothyrium in having immersed to sub-peridermal conidiomata, a conidiomatal wall of brown cells of textura angularis, hyaline, branched conidiophores, enteroblastic, phialidic, cylindrical conidiogeneous cells and cylindrical pale brown conidia. The genus is also morphologically similar to coniothyrium-like taxa, such as Coniothyrium, Cytoplea and Microsphaeropsis (Sutton 1971, 1980, Verkley et al. 2004, 2014, de Gruyter et al. 2013). Dothichiza was previously accommodated in Dothioraceae. Cultures and sequences are available. In our phylogenetic analysis, the putative strains of Dothichiza pithyophila (dH 12609 and CBS 215.50) are segregated into 2 different subclades distant to each other; strain CBS 215.50 forms a clade close to Sydowia polyspora (CBS 162.9) in the family Dothideaceae and Dothidea pithyophila (HJ22-4, dH_12609) forms an independent lineage close to Pseudoydowia eucalypti (CPC 14927, CBS 14028) in the family Aureobasidiaceae (data not shown). We therefore, retain the genus Dothichiza in Dothideomycetes, genera incertae sedis until further confirmation.

Dothichiza populea Sacc. \& Briard, in Saccardo, Syll. fung. (Abellini) 3: 672 (1884)

Fig. 50

$\equiv$ Chondroplea populea (Sacc. \& Briard) Kleb., Phytopath. Z. 6: 291 (1933)

Index Fungorum number: IF275050; Facesoffungi number: FoF 06235

Pathogenic on various substrates of a range of host plants. Sexual morph: Undetermined. Asexual morph: Conidiomata 254-744 $\mu \mathrm{m}$ high $\times 874-1063 \mu \mathrm{m}$ diam $(\bar{x}=433.8 \times 972.8 \mu \mathrm{m}, \mathrm{n}=$ 10), numerous in the bark, stromatic, initially in pustules covered by the epidermis of the host, rupturing at the apex when mature, immersed to sub-peridermal, solitary, multilocular and convoluted, often irregular in shape, dark brown to black, ostiolate. Conidiomata wall 11.2-26.6 $\mu \mathrm{m}$ with irregular surface at the base on the inside, outer layer composed of 2-3 layers of brown cells of textura angularis, inner layer composed of hyaline-walled cells of textura angularis. Conidiophores 4-6 $\mu \mathrm{m} \times 1 \mu \mathrm{m}(\bar{x}=5 \times 1 \mu \mathrm{m}, \mathrm{n}=10)$, hyaline, branched at the base, septate, smooth, hyaline. Conidiogenous cells enteroblastic, phialidic, cylindrical, indeterminate, integrated or discrete, hyaline, smooth. Conidia $2-3 \mu \mathrm{m} \times 1-2 \mu \mathrm{m}(\bar{x}=3.6 \times 2.1 \mu \mathrm{m}, \mathrm{n}=10)$, subglobose to ovoid, or rarely ellipsoid, apex obtuse, base truncate or rounded, aseptate, creamy to tanny olive or pale brown, median guttulate, thick and smooth-walled.

Material examined - USA, New York, Dutchess, Poughkeepsie, on Populus nigra (Salicaceae), 25 May 1923, Unknown collector (CUP 012269).

Economic significance -The genus Dothichiza is parasitic and responsible for outbreaks of cankers in many hosts. There is evidence that damage caused from members of the genus Dothichiza is European in origin. Trees under stress are most frequently infected by this taxon and show discoloration of the bark in the cankers (Hedgcock \& Hunt 1916, Phillips \& Burdekin 1992).

\section{Dothivalsaria Petr., Sydowia 19(1-6): 283 (1966)}

Saprobic on dead branches. Sexual morph: Stromata pseudostromatic, immersed or semiimmersed from bark on wood, scattered or gregarious, appearing on the host surface as dark brown to black, smooth, hollow, circular dots. Ascomata subglobose to globose, carbonaceaous, black, solitary, scattered throughout the host, papillate. Peridium composed of pale brown compressed cells of textura angularis. Ostiole inconspicuous at the surface, fragile, shiny. Paraphyses numerous, sparsely branched, hyaline, septate, filamentous, cylindrical, at times irregular, apically free. Asci cylindrical, bitunicate, fissitunicate, 8-spored, apex thin, no ring visible in Congo red. Ascospores uniseriate, ellipsoidal, 1-septate, dark brown, slightly constricted at the septum, surface finely warted or reticulate with the ends broadly rounded. Asexual morph: Undetermined. 


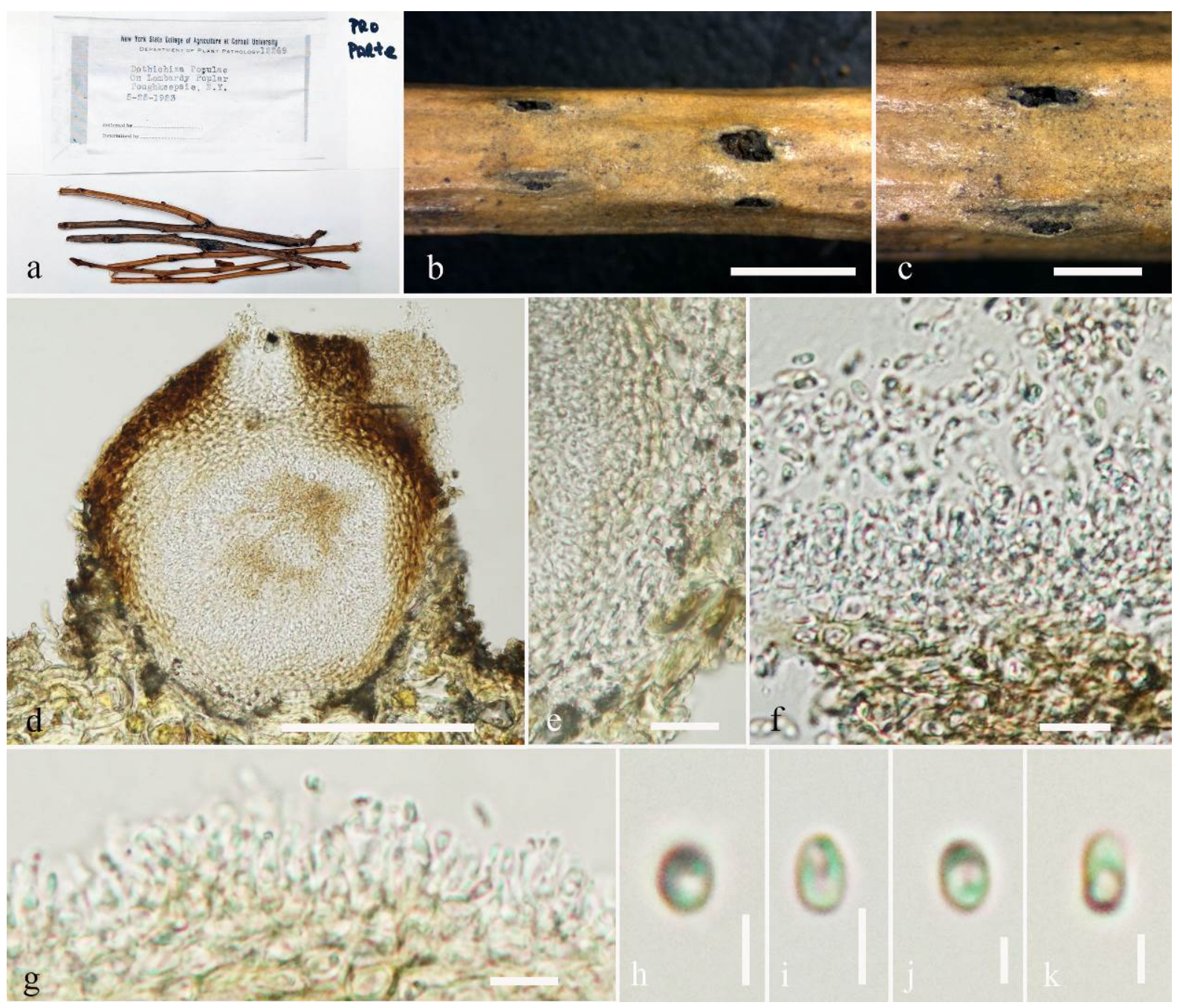

Figure 50 - Dothichiza populea (CUP 012269). a Details of herbarium material. b, c Habit and appearance of conidiomata on host surface. d Section of conidioma. e Peridium. $\mathrm{f}, \mathrm{g}$ Conidiogenesis. h-k Conidia. Scale bars: $b=2 \mathrm{~mm}, \mathrm{c}=1 \mathrm{~mm}, \mathrm{~d}=100 \mu \mathrm{m}, \mathrm{e}=20 \mu \mathrm{m}, \mathrm{f}, \mathrm{g}=10$ $\mu \mathrm{m}, \mathrm{h}-\mathrm{k}=2 \mu \mathrm{m}$.

Type species - Dothivalsaria megalospora (Auersw.) Petr.

Notes - The monotypic genus Dothivalsaria was introduced by Petrak (1965) based on $D$. megalospora. The genus is characterized by immersed, average to large sized ascomata which usually aggregate under blackened stromatic tissues and have trabeculate pseudoparaphyses. Asci are cylindrical. Ascospores are brown, ellipsoid, 1-septate and uniseriate in the asci (Barr 1990). The ascostroma of D. megalospora is similar to those of Aglaospora profusa (Barr 1990), but their relationships are unclear. The genus was previously placed in Massariaceae by Lumbsch \& Huhndorf (2010). However, later it was accepted as a genus in Dothideomycetes, genera incertae sedis (Wijayawardene et al. 2014, 2018). The asexual morph of this genus is unknown. We examined a specimen of Dothivalsaria under the code NY 02977713 but could not find an appropriate placement. The genus Dothivalsaria is therefore retained in Dothideomycetes, genera incertae sedis.

Dothivalsaria megalospora (Auersw.) Petr., Sydowia 19(1-6): 283 (1966) [1965]

Fig. 51

$\equiv$ Valsaria megalospora Auersw., Leipzig. Bot. Tauschver. 5. (1866)

Index Fungorum number: IF 330180; Facesoffungi number: FoF 06237

Current name: Massariovalsa megalospora (Auersw.) E. Müll., in Müller \& von Arx 1962 


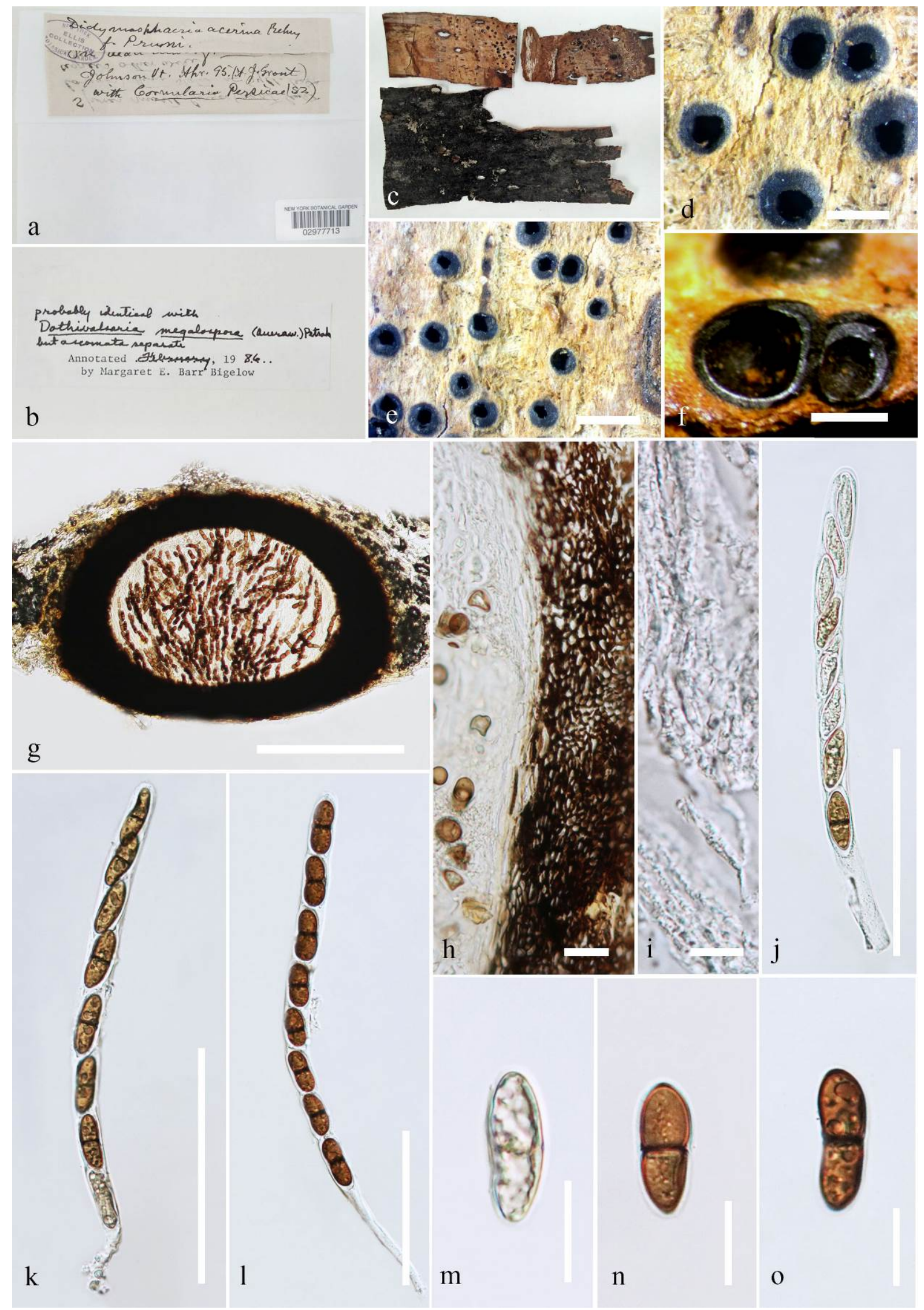

Figure 51 - Dothivalsaria megalospora (NY 02977713). a, b Details of herbarium material. d-f Habit and appearance of ectostromata on host surface. g Vertical section of stroma. h Peridium. i Apically free paraphyses. j-l Asci. $\mathrm{m}-\mathrm{o}$ Ascospores. Scale bars: $\mathrm{d}, \mathrm{f}=1 \mathrm{~mm}, \mathrm{e}=2 \mathrm{~mm}, \mathrm{~g}=400$ $\mu \mathrm{m}, \mathrm{h}, \mathrm{m}-\mathrm{O}=20 \mu \mathrm{m}, \mathrm{i}=10 \mu \mathrm{m}, \mathrm{j}-\mathrm{l}=100 \mu \mathrm{m}$. 
Saprobic on unidentified dried branches. Sexual morph: Stromata pseudostromatic, immersed or semi-immersed from bark on wood, scattered or gregarious, appearing on the host surface as dark brown to black, smooth, hollow, circular dots. Ascomata Ascomata 850-1030 $\mu \mathrm{m}$ high $\times 810$ $\mu \mathrm{m}-1040 \mu \mathrm{m}$ diam. $(\bar{x}=950 \times 910 \mu \mathrm{m}, \mathrm{n}=10)$, subglobose to globose, carbonaceous, black, solitary, scattered throughout the host, papillate. Peridium 25-40 $\mu \mathrm{m}$ thick composed of pale brown compressed cells of textura angularis. Ostiole 200-215 $\mu \mathrm{m} \times 50-68 \mu \mathrm{m}(\bar{x}=212.4 \times 65.1 \mu \mathrm{m}, \mathrm{n}=$ 10 ), inconspicuous at the surface, fragile, shiny. Paraphyses numerous, sparsely branched, hyaline, septate, filamentous, cylindrical, at times irregular, apically free, 2-6 $\mu \mathrm{m}$ wide. Asci 114.4-120.8 $\mu \mathrm{m} \times 4.9-6.5 \mu \mathrm{m}(\bar{x}=117.6 \times 5.7 \mu \mathrm{m}, \mathrm{n}=10)$ cylindrical, bitunicate, fissitunicate, 8-spored, apex thin, no ring visible in Congo Red. Ascospores 31.5-34.1 $\mu \mathrm{m} \times 10.5-10.7 \mu \mathrm{m}(\bar{x}=32.8 \times 10.6$ $\mu \mathrm{m}, \mathrm{n}=10$ ), uniseriate, ellipsoidal, 1-septate, dark brown, slightly constricted at the septum, surface finely warted or reticulate with the ends broadly rounded. Asexual morph: Undetermined.

Material examined - NORTH AMERICA, United States, Johnson, Vermont, on unidentified dried branches, 21 May 1995, A. J. Grout (NY 02977713).

Economic significance - None is reported.

Excipulariopsis P.M. Kirk \& Spooner, in Spooner \& Kirk, Trans. Br. mycol. Soc. 78(2): 251 (1982)

Saprobic on decayed wood with corticeaceous fungus. Sexual morph: formerly known in Kentingia. Asexual morph: Mycelium mostly immersed. Conidiomata superficial, pulvinate, darkbrown to black, setiferous, with basal aggregation of thick-walled, dark brown cells. Setae straight or flexuous, peripheral, arising directly from cells of the basal stroma, subulate, dark brown, septate, thick-walled, smooth, with a pointed apex. Conidiophores micronematous, short, cylindrical, pale-brown, unbranched. Conidiogeneous cells holoblastic, monoblastic, integrated, terminal, and determinate. Conidia acrogenous, solitary, dry, broadly fusoid, truncate at the base, multiseptate, thick and smooth-walled, dark-brown, with hyaline to very pale brown terminal cells.

Type species - Excipulariopsis narsapurensis (Subram.) Spooner \& P.M. Kirk

Notes - Excipulariopsis was introduced by Spooner \& Kirk (1982) for Excipularia narsapurensis found on decayed wood in the USA. Subsequently, Ellis (1976) presented an expanded generic description and illustrated E. narsapurensis Subram., found on unidentified wood and bark in India (Subramanian 1971). This species, rather than the holotype, was used by both Barnett \& Hunter (1972) and Carmichael et al. (1980) to illustrate the genus. The major morphological characters of the genus are the non-falcate, thick-walled, septate conidia and consistently thick-walled, dark brown, subulate setae at the periphery of a non-cupulate conidioma arising directly from the basal stroma. The sexual morph was formerly known in Kentingia. Unfortunately, the taxonomic position of Excipulariopsis remains unresolved as cultures and sequences are unavailable. The genus Excipulariopsis in retained in Dothideomycetes genera incertae sedis.

Excipulariopsis narsapurensis (Subram.) Spooner \& P.M. Kirk, Trans. Br. mycol. Soc. 78(2): 251 (1982)

Fig. 52

E Excipularia narsapurensis Subram., J. Indian bot. Soc. 35(1): 56 (1956)

Index Fungorum number: IF110673; Facesoffungi number: FoF 06242

Saprobic on decayed wood with corticeaceous fungus. Sexual morph: Undetermined. Asexual morph: Mycelium mostly immersed. Conidiomata 46-91 $\mu \mathrm{m}$ high $\times 78-90 \mu \mathrm{m}$ diam., $(\bar{x}=$ $71.9 \times 82.7 \mu \mathrm{m}, \mathrm{n}=10$ ), superficial, pulvinate, setiferous, dark-brown to black with a basal aggregation of thick-walled, dark brown cells. Setae straight or flexuous, peripheral, arising directly from cells of the basal stroma, subulate, reddish brown to dark brown, septate, thick-walled, smooth, pointed at apex. Conidiophores micronematous, short, cylindrical, pale-brown, unbranched. Conidiogeneous cells holoblastic, monoblastic, integrated, terminal, and determinate. Conidia 68-72 $\mu \mathrm{m} \times 23-27 \mu \mathrm{m}(\bar{x}=70.5 \times 26.7 \mu \mathrm{m}, \mathrm{n}=10)$, acrogenous, solitary, dry, broadly 
fusoid, truncate at the base, multiseptate,dark-brown, with hyaline to very pale brown terminal cells, thick and smooth-walled.

Material examined - USA, Hawaii, Molokai, Kau, Mt. House trip, on decayed wood with corticeaceous fungus, 9 June 1952, M.L. Lohman s.n. (BISH 594584).

Economic significance - The genus Excipulariopsis seems to be both saprobic and pathogenic as it has also been reported in Cocos nucifera L in India (Dubey \& Pandey 2019).

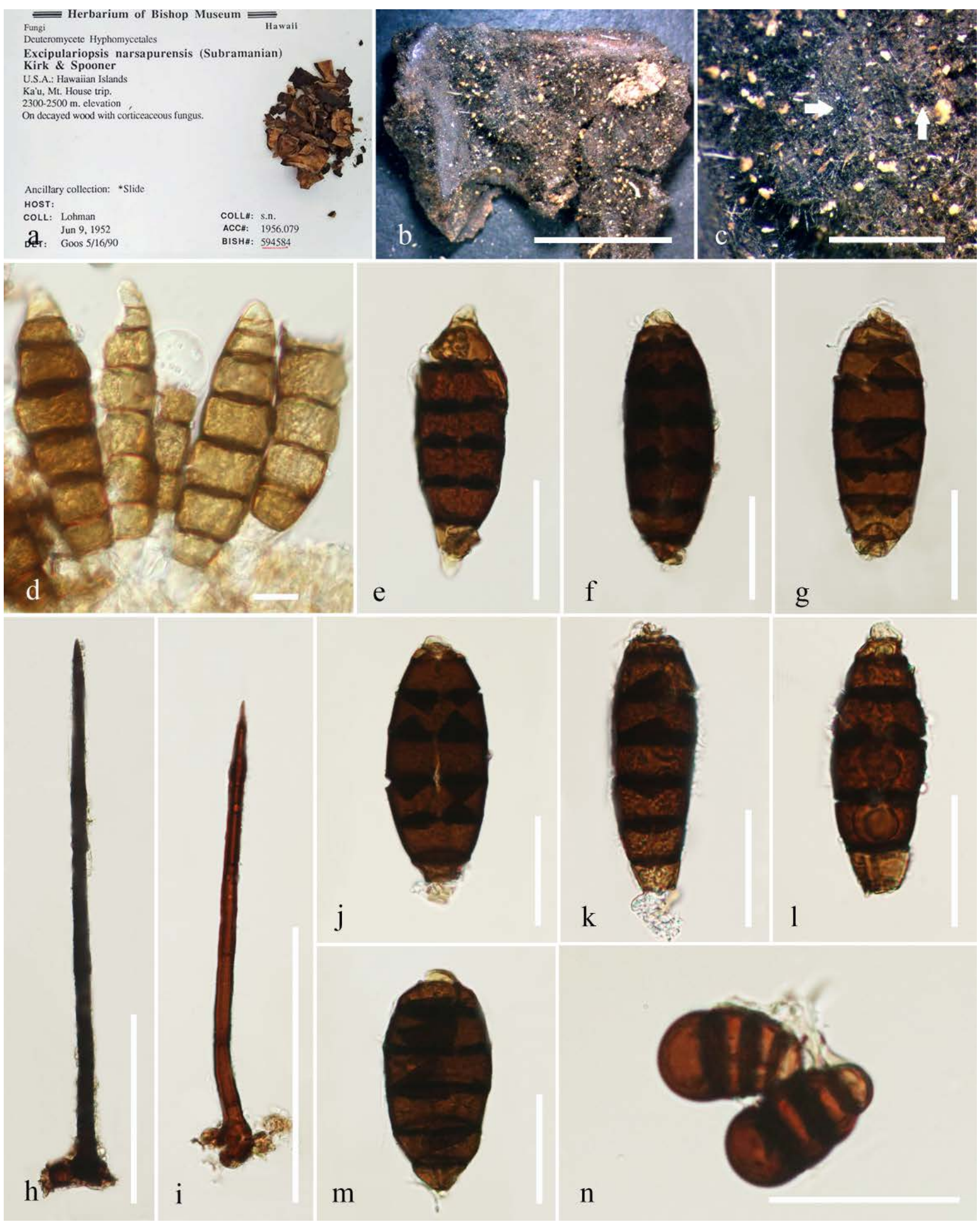

Figure 52 - Excipulariopsis narsapurensis (BISH 594584) a, b Herbarium material. c Appearance of conidiomata on host surface. d Conidiogenesis. h, i Setae. j-n Conidia. Scalebar: $b=2 \mathrm{~mm}, \mathrm{c}=1$ mm, $d=10 \mu m, e, f, j-n=30 \mu m, h, i=100 \mu m$. 
Gilletiella Sacc. \& P. Syd., Syll. fung. (Abellini) 14(2): 691 (1899)

Foliicolous in undergrowth of Chusquea serrulata. Thallus crustose, thick, ecorticate. Sexual morph: Ascomata small, solitary or scattered, concentrically arranged, covered by the algal layer, lenticular to conical, rounded or outwardly elongate, dark brown to black, top rounded, with dark brown, conical involucrellum below the algal layer and dark brown, membranous involucrum (peridium) surrounding the subglobose nucleus, without apparent ostiole. Peridium thin, single layered composed of brown, septate hyphae relatively conglutinated into textura epidermoidea to intricata. Hamathecium gelatinous. Pseudoparaphyses lacking. Asci 8-spored, bitunicate, fissitunicate, obclavate, without a distinct ocular chamber. Ascospores 2-3-seriate irregularly arranged in asci, fusiform, pale grayish, 1-septate to submuriform, smooth-walled, ends rounded, without endospore, without perispore. Asexual morph: Undertermined.

Type species - Gilletiella chusqueae (Pat.) Sacc. \& P. Syd.

Notes - The monotypic genus Gilletiella was introduced by Patouillard \& Lagerheim (1899) based on the type species $G$. chusqueae, which was found on matrix of Chusquea serrulata from Ecuador. Saccardo \& Sydow (1899) redescribed the genus. The genus is characterized by a hypostromatic perithecia, 8-spored bitunicate asci, 3-septate pale grayish ascospores. The asexual morph of the genus is coelomycetous (ascochyta-like). Gilletiella was compared to Micropeltis in having similar stromata and Polystomella with respect to the ascospores (Patouillard \& Lagerheim 1899). The species lack sequence data. We therefore, retain the genus in Dothideomycetes, genera incertae sedis.

Gilletiella chusqueae (Pat.) Sacc. \& P. Syd., Syll. fung. (Abellini) 14(2): 691 (1899) Fig. 53 三 Heterochlamys chusqueae Pat., in Patouillard \& Lagerheim 1895

Index Fungorum number: IF 223231; Facesoffungi number: FoF 06244

Foliicolous in undergrowth of Chusquea serrulata. Thallus crustose, thick, ecorticate. Sexual morph: Ascomata 0.1-0.2 mm diam., solitary or scattered, concentrically arranged, covered by the algal layer, lenticular to conical, rounded or outwardly elongate, dark brown to black, top rounded, with dark brown, conical involucrellum below the algal layer and dark brown, membranous involucrum (peridium) surrounding the subglobose nucleus, without apparent ostiole. Peridium 32$38 \mu \mathrm{m}$ thin, single layered composed of brown, septate hyphae relatively conglutinated into textura epidermoidea to intricata. Hamathecium gelatinous, lacking pseudoparaphyses. Asci $52-54 \mu \mathrm{m} \times$ 11.4-11.5 $\mu \mathrm{m}(\bar{x}=53.2 \times 11.5 \mu \mathrm{m}, \mathrm{n}=10), 8$-spored, bitunicate, fissitunicate, obclavate, without a distinct ocular chamber. Ascospores 14.8-15.0 $\mu \mathrm{m} \times 4.7-4.9 \mu \mathrm{m}(\bar{x}=14.9 \times 4.9 \mu \mathrm{m}, \mathrm{n}=10)$, 2-3seriate irregularly arranged in asci, fusiform, 1-septate to submuriform, ends rounded, without endospore, without perispore, pale grayish, smooth-walled. Asexual morph: Undertermined.

Material examined - ECUADOR, Tungurahua, on matrix of Chusquea serrulata (Poaceae), 20 December 1937, H. Sydow (S-F46336).

Economic significance - None is reported.

Harknessiella Sacc., Syll. fung. (Abellini) 8: 845 (1889)

Saprobic on lower surface of leaves. Sexual morph: Ascomata scattered, solitary, superficial, and globose to subglobose, easily removable from the host surface, with setae, glabrous, ostiolate at centre, with minute papilla internally lined with short, brown, aseptate periphyses. Peridium thinwalled, of equal thickness, composed of several layers of small, flattened, brown to dark brown cells of textura angularis. Hamathecium composed of dense, broad filamentous, distinctly septate, anastomosed pseudoparaphyses, trabeculate, embedded in a hyaline gelatinous matrix. Asci 8spored, bitunicate, fissitunicate, fusiform to ellipsoidal, cylindrical to cylindric-clavate, short pedicellate, apically rounded, with an ocular chamber. Ascospores overlapping 1-2-seriate, hyaline, with rounded ends, 3-septate, slightly constricted at the central septum, smooth-walled. Asexual morph: Pycnidia hypophyllous, dark brown to black, superficial, sparsely scattered or sporadically distributed on surface of leaves, easily removable from the host substrate. Conidiophores straight or slightly curved, hyaline, reduced to conidiogenous cells. Conidiogenous cells holoblastic, 
percurrent, cylindrical to elliptical, septate, rough and thick-walled. Conidia 2-3 septate, ellipsoidal to cylindrical, hyaline to olivaceous-green, smooth-walled.

Type species - Harknessiella purpurea (W. Phillips \& Harkn.) Sacc.

Notes - The genus Harknessiella was introduced by Saccardo (1889) with Harknessiella purpurea as the type species. The latter was also found on lower surface of leaves of Garrya elliptica. The genus is characterized by globose to subglobose, superficial ascomata, consisting of dark-brown setae, cylindrical to cylindric-clavate asci and fusiform to ellipsoidal ascospores. We re-examined a specimen of Harknessiella purpurea under the code C0170081F from F herbarium. It seems that the genus Harknessiella shares similar characters with the genus Aphanostigme in Phaeosphaeriaceae (Boonmee et al. 2017). However, we retain the genus Harknessiella to Dothideomycetes, genera incertae sedis until fresh collections are available for further molecular studies.

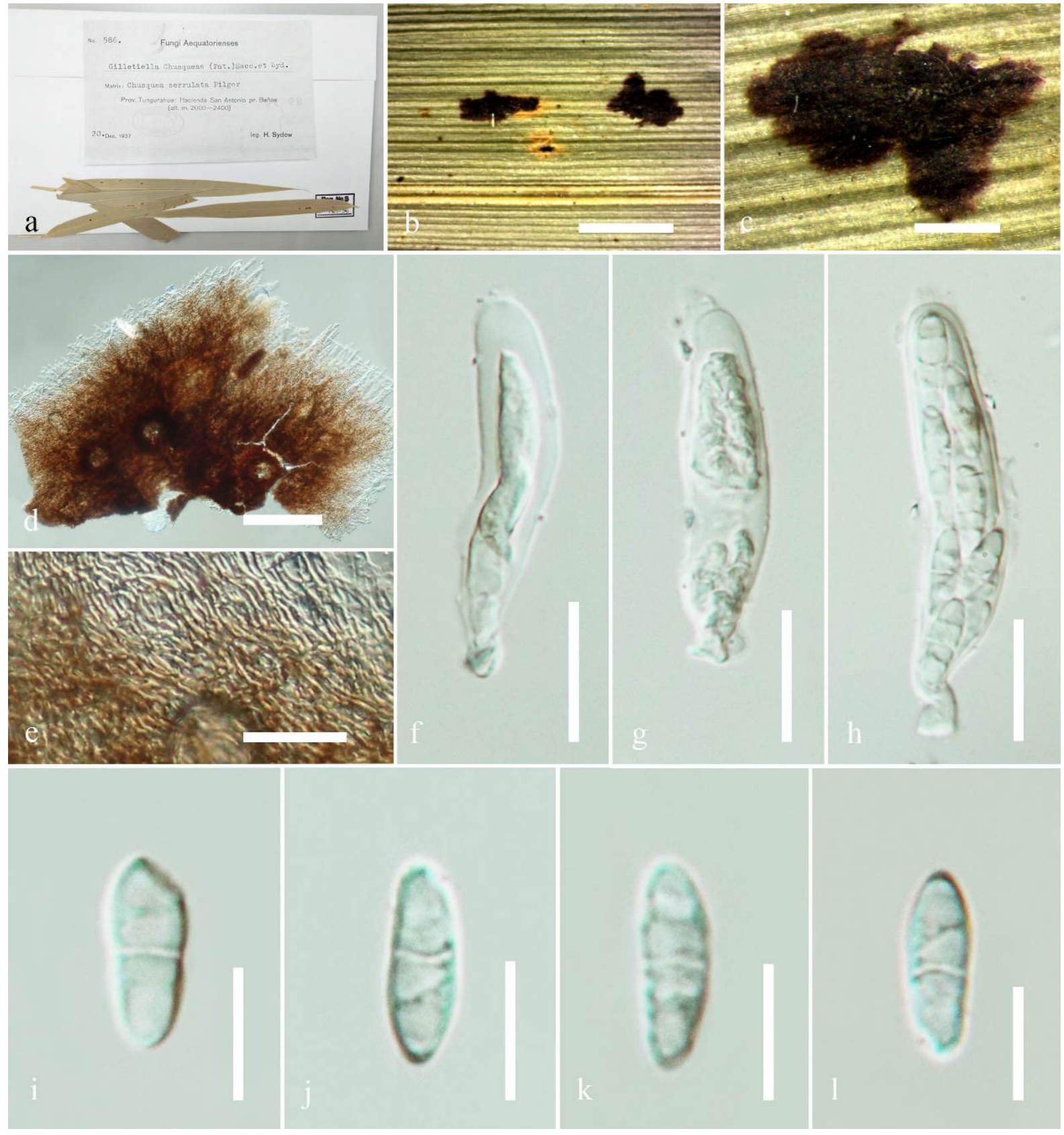

Figure 53 - Gilletiella chusqueae (S-F46336). a Details of herbarium material. b, c Habit and appearance of ectostromata on host surface. d Squash mount of ascoma. e Peridium. f-h Asci. i-l Ascospores. Scale bars: $\mathrm{b}=2 \mathrm{~mm}, \mathrm{c}=500 \mu \mathrm{m}, \mathrm{d}=200 \mu \mathrm{m}, \mathrm{e}=30 \mu \mathrm{m}, \mathrm{f}-\mathrm{h}=20 \mu \mathrm{m}, \mathrm{i}-\mathrm{l}=10 \mu \mathrm{m}$. 
三 Phillipsiella purpurea W. Phillips \& Harkn., Bull. Calif. Acad. Sci. 1(no. 1): 23

Index Fungorum number: IF147107; Facesoffungi number: FoF 06245

Saprobic on lower surface of Garrya elliptica leaves. Sexual morph: Ascomata 315-417 $\mu \mathrm{m}$ high, $\times$ 479-542 $\mu \mathrm{m}$ diam., scattered, solitary, superficial, globose to subglobose, easily removable from the host surface, consist of setae, glabrous, ostiolate at centre, with minute papilla lined with short, brown, aseptate periphyses. Peridium 18-28 $\mu \mathrm{m}$ wide, thin-walled, of equal thickness, composed of several layers of small, flattened, brown to dark brown cells of textura angularis. Hamathecium 3-4 $\mu \mathrm{m}$ wide composed of dense, 2-3 $\mu \mathrm{m}$ wide, broad filamentous, distinctly septate, anastomosed pseudoparaphyses, embedded in a hyaline gelatinous matrix. Asci 79-103 $\mu \mathrm{m}$ $\times 9-11 \mu \mathrm{m}(\bar{x}=92.6 \times 9.1 \mu \mathrm{m}, \mathrm{n}=10), 8$-spored, bitunicate, fissitunicate, cylindrical to cylindricclavate, short pedicellate, apically rounded, with an ocular chamber. Ascospores 17-21 $\mu \mathrm{m} \times 3-4$ $\mu \mathrm{m}(\bar{x}=19.6 \times 3.9 \mu \mathrm{m}, \mathrm{n}=10)$, overlapping 1-2-seriate, hyaline, fusiform with rounded ends, 3septate, slightly constricted at the central septum, smooth-walled. Asexual morph: Pycnidia 302$358 \mu \mathrm{m} \times 485-502 \mu \mathrm{m}(\bar{x}=311.6 \times 499.5 \mu \mathrm{m}, \mathrm{n}=10)$, hypophyllous, dark brown to black, superficial sparsely scattered or sporadically distributed on surface of leaves, easily removable from the host substrate. Conidiophores straight or slightly curved, hyaline, reduced to conidiogenous cells. Conidiogenous cells holoblastic, percurrent, cylindrical to elliptical, septate, rough and thick-walled. Conidia $10-14 \mu \mathrm{m} \times 2-3 \mu \mathrm{m}(\bar{x}=12.8 \times 2.6 \mu \mathrm{m}, \mathrm{n}=10)$, hyaline to olivaceous-green, $2-3$ septate, ellipsoidal to cylindrical, smooth-walled.

Material examined - USA, California, near Tamalpais, on lower surface of leaf of Garrya elliptica (Garryaceae), 8 July 1913, J.J Davis (C0170081F).

Economic significance - The genus Harknessiella causes yellow leaf spots on leaves of hosts (Saccardo 1889).

\section{Hypobryon Döbbeler, Nova Hedwigia 37(1): 3 (1983)}

Saprobic on lower leaflets of Porella sp. Sexual morph: Ascomata globose to subglobose, black, scattered or in a group, superficial, carbonaceous, papillate. Peridium membranous composed of 2 layers of cells, the inner layer consisting of brown cells of textura angularis with the outer layer consisting of thicker dark-brown cells of textura globulosa. Hamathecium composed of dense, hyaline, pseudoparaphyses surrounding the asci. Asci not observed. Hymenium at the base is gelatinous. Ascospores ellipsoid, 4-celled, hyaline at first becoming pale brown at maturity, straight or slightly curved often slightly constricted. Asexual morph: Undetermined.

Type species - Hypobryon poeltii (Döbbeler) Döbbeler

Notes - The genus Hypobryon is a remarkable bryophilic genus characterized by hypophyllous ascomata which perforate the moss leaf to release ascospores on the upper surface. A combination of appressoria and intraparietal haustoria can be seen in this genus (Döbbeler 1983). The type species Hypobryon poeltii was found on Porella sp. (Porellaceae). Currently, seven species are accommodated in the genus Hypobryon. The asexual morph is unknown. Cultures and sequences are unavailable. We examined the holotype specimen of Hypobryon poeltii from GZU herbarium but could not observe all the morphological characters. Thus, we retain Hypobryon in Dothideomycetes genera incertae sedis. Fresh specimen with asexual morph link and sequence data would be required to provide exact placement for this genus.

Hypobryon poeltii (Döbbeler) Döbbeler, Nova Hedwigia 37(1): 12 (1983)

Fig. 55-57

三 Punctillum poeltii Döbbeler, Mitt. bot. StSamml., Münch. 14: 203 (1978)

Index Fungorum number: IF322097; Facesoffungi number: FoF 06249

Saprobic on lower leaflets of Porella sp. Sexual morph: Ascomata 65-101 $\mu \mathrm{m}$ high $\times$ 55-99 $\mu \mathrm{m}$ diam., $(\bar{x}=76.9 \times 83.8 \mu \mathrm{m}, \mathrm{n}=20)$, globose to subglobose, black, scattered or in a group, superficial, carbonaceous, papillate. Peridium membranous, composed of 2 layers of cells, with the inner layer consisting of brown cells of textura angularis with the outer layer consisting of thicker 
dark-brown cells of textura globulosa. Hamathecium composed of dense, hyaline, pseudoparaphyses surrounding the asci. Asci not observed. Hymenium at the base is gelatinous. Ascospores 15-19 $\mu \mathrm{m} \times 4-6 \mu \mathrm{m}(\bar{x}=17.2 \times 5.5 \mu \mathrm{m}, \mathrm{n}=20)$, ellipsoid, 2-3 septate, hyaline at first becoming pale brown at maturity, straight or slightly curved often slightly constricted. Asexual morph: Undetermined.

Material examined - AUSTRIA, Styria, surroundings of Graz: slopes between Stift Rein and Pleschwirt (Kehrerbach-Tal), northwestl, near Graz, on Porella sp (Porellaceae), 14 April 1974, P. Döbbeler s.d. (GZU 000291902, holotype).

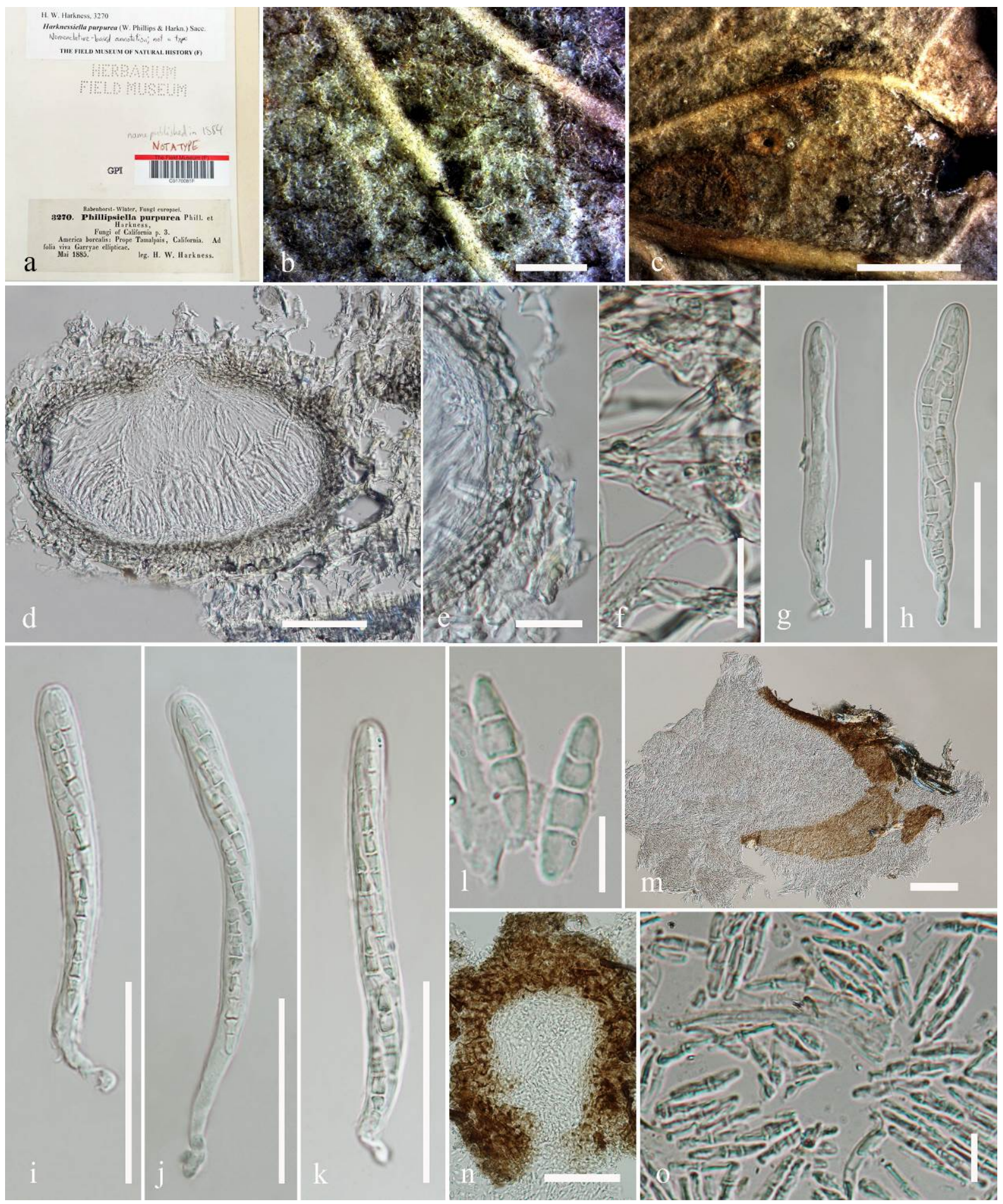

Figure 54 - Harknessiella purpurea (C0170081F). a Details of herbarium material. b, c Host and close up ascoma on host. d Section through an ascoma. e Peridium. f Hamathecium. g-k Asci. 1 
Ascospores. m, $\mathrm{n}$ Conidiomata. o. Conidia. Scale bars: $\mathrm{b}=500 \mu \mathrm{m}, \mathrm{c}=1 \mathrm{~mm}, \mathrm{~d}=200 \mu \mathrm{m}, \mathrm{e}, \mathrm{m}=$ $100 \mu \mathrm{m}, \mathrm{f}, \mathrm{l}, \mathrm{o}=10 \mu \mathrm{m}, \mathrm{g}=20 \mu \mathrm{m}, \mathrm{h}-\mathrm{k}, \mathrm{n}=50 \mu \mathrm{m}$.

Economic significance - Species of Hypobryon are bryophilous or grow on mosses (Döbbeler 1997).

Notes - We could not observe the asci of Hypobryon poeltii as the specimen was dry. The original author described the asci as 'measuring about 25-35 $\mu \mathrm{m} \times 12-21 \mu \mathrm{m}$, cylindrical at first becoming widely ellipsoidal or ovoid, 4-spored’.

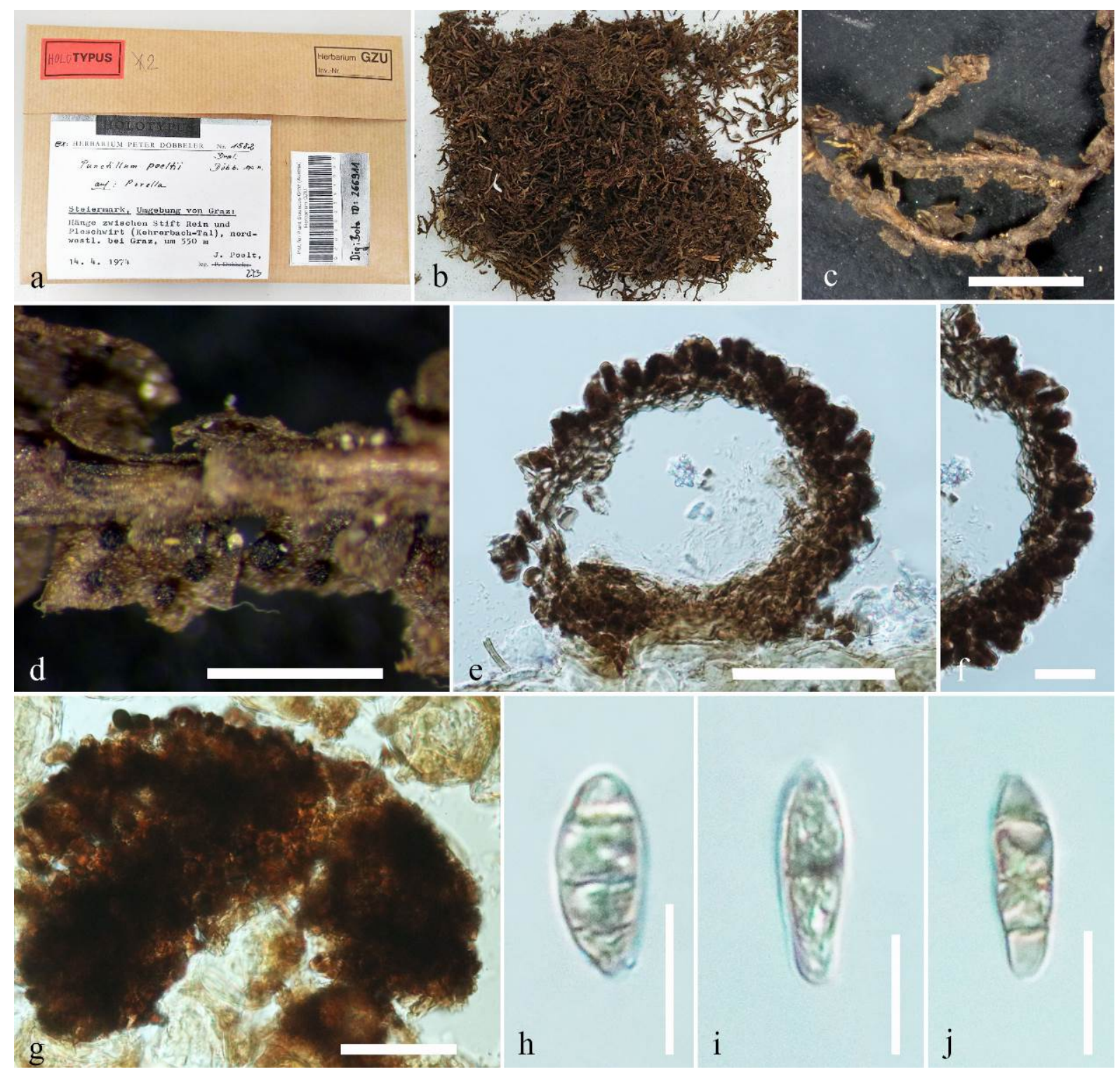

Figure 55 - Punctillum poeltii (GZU 000291902, holotype). a, b Details of herbarium material. c, d Habit and appearance of ascomata on host surface e Vertical section of ascomata. f Peridium. g Squash mount of ascoma. $\mathrm{h}-\mathrm{j}$ Ascospores. Scale bars: $\mathrm{c}=2 \mathrm{~mm}, \mathrm{~d}=500 \mu \mathrm{m}, \mathrm{e}, \mathrm{g}=50 \mu \mathrm{m}, \mathrm{f}=20$ $\mu \mathrm{m}, \mathrm{h}-\mathrm{j}=10 \mu \mathrm{m}$.

Lignosphaeria Boonmee, Thambug. \& K.D. Hyde, in Thambugala et al., Fungal Diversity: 10.1007/s13225-015-0348-3, [61] (2015)

Saprobic on dead wood. Sexual morph: Ascomata scattered to gregarious, superficial or semiimmersed to densely erumpent, carbonaceous, dark brown to black, globose to subglobose. Ostiole slit-like, central, papillate, periphysate. Peridium broad at the apex, comprising several layers of dark brown to black cells of textura angularis, fusing at the outside with the host tissues. 
Hamathecium 1-3 $\mu \mathrm{m}$ of septate, long, hyaline, anastomosing and branched, cellular pseudoparaphyses, embedded in gel matrix between and above the asci. Asci 8-spored, bitunicate, cylindrical to clavate, long pedicellate, apically rounded, with a minute ocular chamber. Ascospores uni to bi-seriate, hyaline, cylindrical to fusiform, with narrowly rounded ends, wide at the second cell from the apex, 3-septate, constricted at the septa, cell above central septum widest, small guttulate, smooth-walled, lacking a mucilaginous sheath. Asexual morph: Undetermined.

Type species - Lignosphaeria thailandica Boonmee, Thambugala \& K.D. Hyde

Notes - The genus Lignosphaeria was introduced by Boonmee et al. (2015) with Lignosphaeria thailandica as the type species. Lignosphaeria was compared with Thyridaria (Hyde et al. 2013) in having immersed to erumpent ascomata, pseudoparaphyses and cylindrical to fusiform ascospores with narrowly rounded or acute ends. In a phylogenetic analyses carried out by Thambugala et al. (2015), the genus Lignosphaeria formed a clade in between Floricolaceae and Amorosiaceae basal to the genus Thyridaria. In our analyses, the genus Lignosphaeria positions itself in between Floricolaceae and Lophiostomataceae as an independent lineage. It seems that a new family should be introduced for this genus however more sequences are required to confirm this hypothesis as only internal transcribed spacer (ITS) gene and 28S large ribosomal subunit RNA gene regions have been deposited in GenBank (Fig. 58). We therefore, retain the genus in the Dothideomycetes genera incertae sedis.

Lignosphaeria thailandica Boonmee, Thambug. \& K.D. Hyde, in Thambugala et al., Fungal Diversity: 10.1007/s13225-015-0348-3, [62] (2015)

Index Fungorum number: IF551282; Facesoffungi number: FoF01089

Fig. 59

Saprobic on dead wood. Sexual morph: Ascomata 385-470 $\mu \mathrm{m}$ high $\times 300-325 \mu \mathrm{m}$ diam. $(\bar{x}=355.2 \times 301.2 \mu \mathrm{m}, \mathrm{n}=3)$, scattered to gregarious, superficial or semi-immersed to densely erumpent, carbonaceous, dark brown to black, globose to subglobose. Ostiole slit-like, central, papillate, periphysate. Peridium 16-24 $\mu \mathrm{m}$ wide, broad at the apex, comprising several layers of dark brown to black cells of textura angularis, fusing at the outside with the host tissues. Hamathecium 1-3 $\mu \mathrm{m}$ wide, long, hyaline, anastomosing and branched, cellular pseudoparaphyses, embedded in gel matrix between and above the asci. Asci 53-81 $\times 6-8 \mu \mathrm{m}(\bar{x}=72.9 \times 7.2 \mu \mathrm{m}, \mathrm{n}=$ 10), 8-spored, bitunicate, cylindrical to clavate, long pedicellate, apically rounded, with a minute ocular chamber. Ascospores 15-18 $\times 3-5 \mu \mathrm{m}(\bar{x}=16.7 \times 3.3 \mu \mathrm{m}, \mathrm{n}=10)$, uni to bi-seriate, hyaline, cylindrical to fusiform, with narrowly rounded ends, wide at the second cell from the apex, 3-septate, constricted at the septa, cell above central septum widest, small guttulate, smooth-walled, lacking a mucilaginous sheath. Asexual morph: Undetermined.

Material examined - THAILAND, Chiang Mai Province, Muang, Doi Su Thep, Huai Kok Ma, on dead wood, 21 April 2011, S. Boonmee, DST-04 (MFLU 11-0135, holotype)

Economic Significance - None is reported.

Limaciniopsis J.M. Mend., in Stevens, Bulletin of the Bernice P. Bishop Museum, Honolulu, Hawaii 19: 58 (1925)

Saprobic and parasitic on leaves of Rollandia racemosa. Sexual morph: Mycelium perisporioid, hyaline, filiform. Ascomata few, solitary, or in small groups, superficial, globular, amber-colored to dark brown, gelatinous, ostiolate, setae absent. Peridium thin, carbonaceous or membranaceous, 2-3-layered, composed of dark brown cells of textura angularis. Hamathecium of dense asci, lacking pseudoparaphyses. Asci 8-spored, bitunicate, fissitunicate, broadly clavate, with a short pedicel. Ascospores oblong to ellipsoid, hyaline when young, turning reddish brown at maturity, 4-celled, slightly constricted at the septum with two end cells hyaline. Asexual morph: Undetermined.

Type species - Limaciniopsis rollandiae J.M. Mend.

Notes - Mendoza (1925) described the genus Limaciniopsis amongst the Capnodiaceae for the single species found related with a blue-green alga on leaves of Rollandia racemosa in Oahu, Hawaii. 


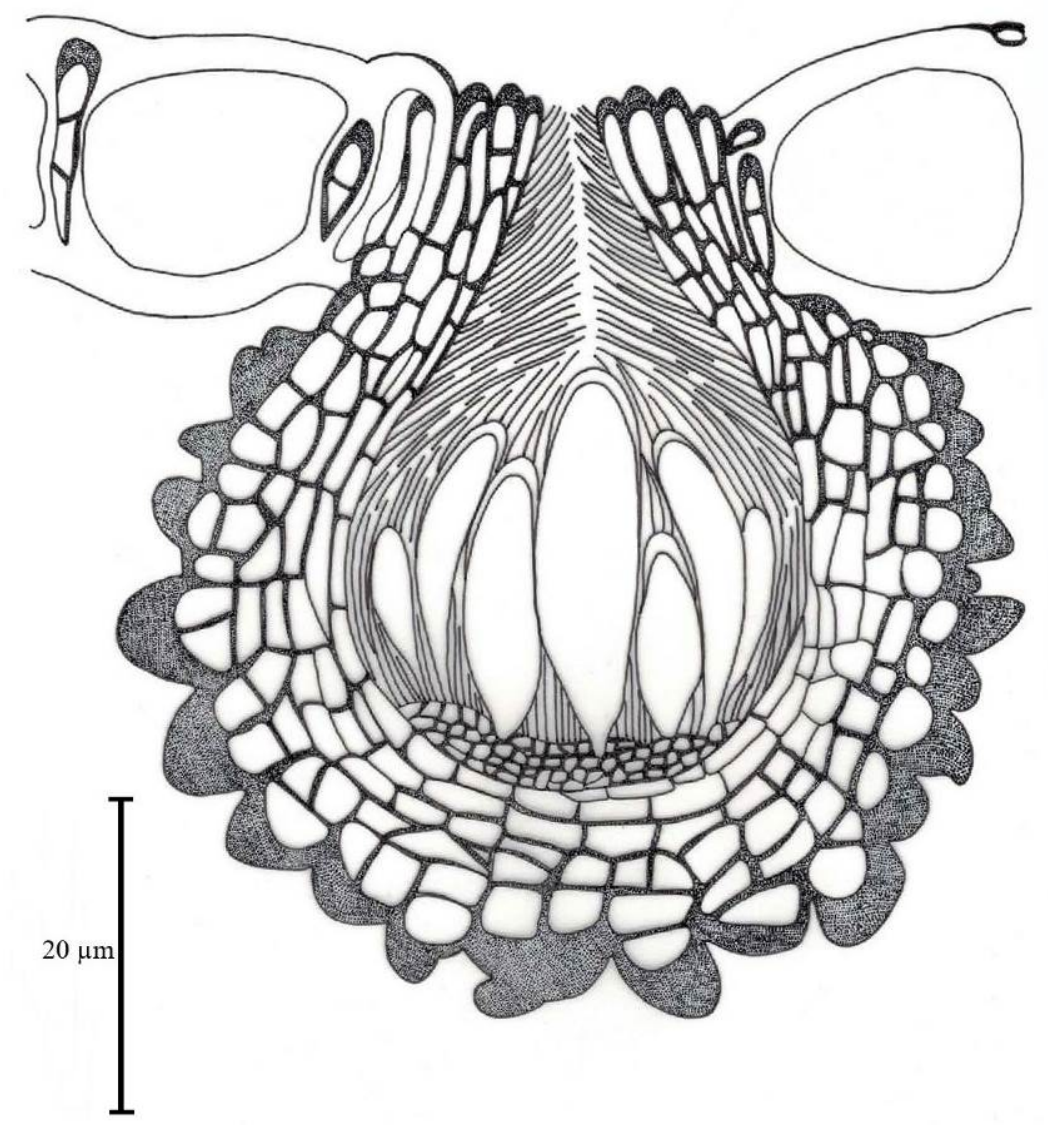

Figure 56 - Ascoma of Punctillum poeltii (holotype); redrawn from Döbbeler (1978).

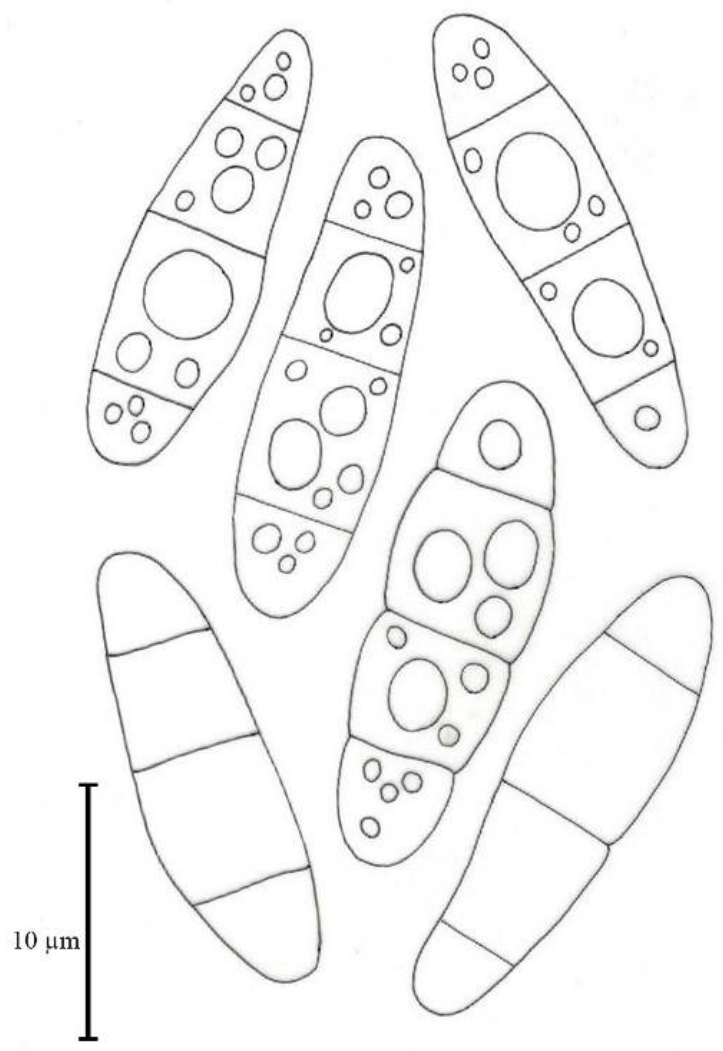

Figure 57 - Ascospores of Punctillum poeltii (holotype); redrawn from Döbbeler (1978). 


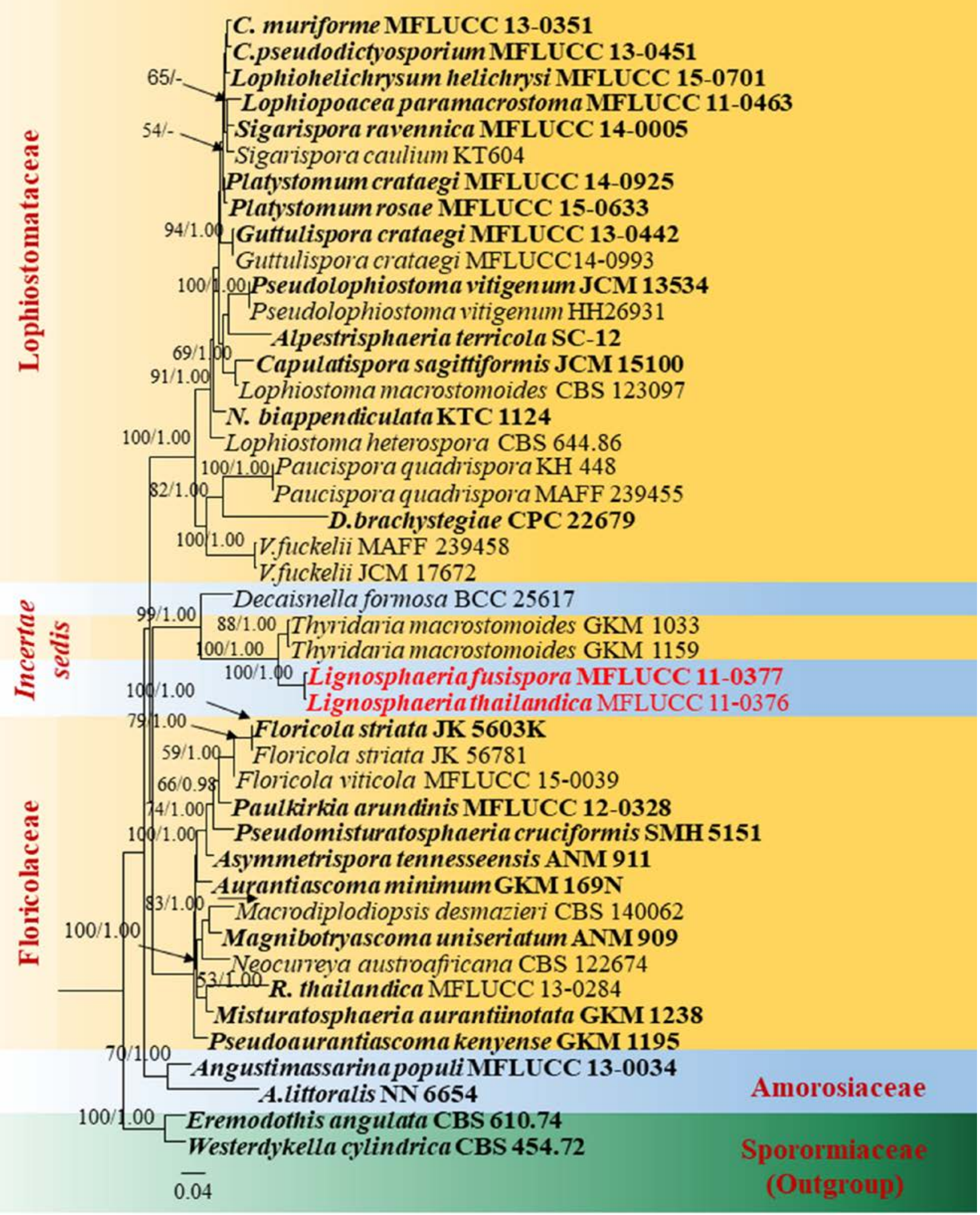

Figure 58 - Phylogram generated from maximum likelihood analysis based on LSU and ITS sequence data retrieved from the GenBank. Related sequences were referred to Liu et al. (2017) and Thambugala et al. (2017). Forty-four taxa are included in the genes sequence analyses which comprise total 2229 characters after alignment. Eremodothis angulata (CBS 610.74) and Westerdykella cylindrica (CBS 454.72) are used as the out-group taxa. Maximum likelihood (ML) analysis was conducted in the CIPRES Science Gateway V. 3.3. The best sorting RaXML tree with a final likelihood value of -9834.122464 is presented. Estimated base frequencies were as follows: $\mathrm{A}=0.252590, \mathrm{C}=0.229863, \mathrm{G}=0.288440, \mathrm{~T}=0.229108$; substitution rates $\mathrm{AC}=1.924217, \mathrm{AG}$ 
$=2.620898, \mathrm{AT}=2.094050, \mathrm{CG}=1.166547, \mathrm{CT}=10.037969, \mathrm{GT}=1.000000$; gamma distribution shape parameter $\alpha=0.504667$; proportion of invariant 0.393490 . ML bootstrap values $\geq 50 \%$ are given as the first set of numbers and approximate likelihood-ratio test (aLRT) $\geq 0.90$ values as the second set of numbers above the nodes. Voucher/strain numbers are given after the taxon names, the one from type material are indicated in bold face. Sequence of interest is indicated in red. The bar length indicates the number of nucleotide substitutions per site.

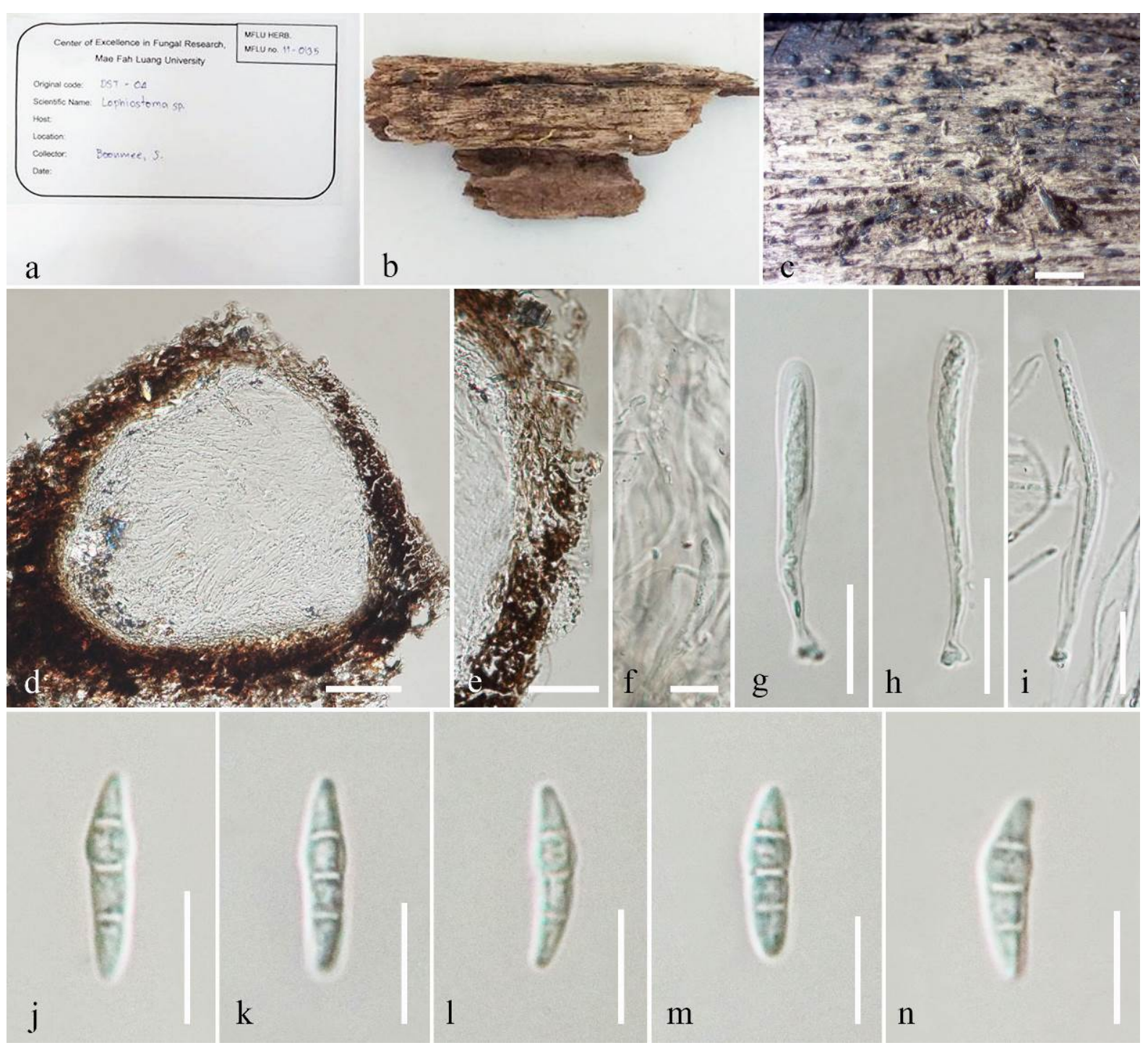

Figure 59 - Lignosphaeria thailandica (MFLU 11-0135, holotype). a, b Details of herbarium material. c Habit and appearance of ascomata on host surface. $d$ Section of ascoma. e Peridium. $f$ Hamathecium. g-i Asci. j-n Ascospores. Scale bars: $c=1 \mathrm{~mm}, \mathrm{~d}=50 \mu \mathrm{m}$, e, $\mathrm{g}-\mathrm{i}=20 \mu \mathrm{m}, \mathrm{f}=5$ $\mu \mathrm{m}, \mathrm{j}-\mathrm{n}=10 \mu \mathrm{m}$.

Batista \& Vital (1957) reported that the species was a pyrenomycete and was parasitic on the mycelium of Sporoschisma sp. Batista and Vital (1957) described the asci as unitunicate in their illustrated account which matches that of Mendoza reasonably well. We could not observe the asci in the specimen that we examined. However, Batista \& Ciferri (1963) referred to Limaciniopsis as a synonym of Phragmocapnias Theiss. \& Syd. (q.v.), and consequently Limaciniopsis rollandiae was referred as a synonym of Phragmocapnias callitris (McAlpine) Cif. \& Bat. (= Capnodium callitris McAlp. = Capnodium salicinum Mont. fide Fraser, 1935b). The asci of Phragmocapnias callitris were defined as bitunicate by Batista \& Ciferri (1963) but no reference was made to 'Sporoschisma' which accompanies Limaciniopsis rollandiae. On other hand, Limaciniopsis was cited as a 
synonym of Capnodium by Von Arx \& Muller (1975). We examined the type collection from BISH under the code BISH 499971. Unfortunately, we could not observe the asci as the specimen was in poor condition. However, it is clear that the genus is characterized by oblong to ellipsoidal, reddish brown ascospores. The genus Limaciniopsis is retained in Dothideomycetes, genera incertae sedis until fresh collections and molecular data are obtained.

Limaciniopsis rollandiae J.M. Mend., in Stevens, Bulletin of the Bernice P. Bishop Museum, Honolulu, Hawaii 19: 58 (1925)

Fig. 60

Index Fungorum number: IF 276675; Facesoffungi number: FoF 06250

Saprobic and parasitic on leaves of Rollandia racemosa. Sexual morph: Mycelium perisporioid, hyaline, filiform. Ascomata 46-59 $\mu \mathrm{m} \times 60-83 \mu \mathrm{m}(\bar{x}=61.6 \times 70 \mu \mathrm{m}, \mathrm{n}=10)$, solitary, or in small groups, superficial, globular, amber-colored to dark brown, gelatinous, ostiolate, setae absent. Peridium 20.9-25.6 $\mu \mathrm{m}$, thin, carbonaceous or membranaceous, 2-3 layered, composed of dark brown cells of textura angularis. Hamathecium of dense asci, lacking pseudoparaphyses. Asci 31-44 $\mu \mathrm{m} \times 11-13 \mu \mathrm{m}(\bar{x}=36.8 \times 12.3 \mu \mathrm{m}, \mathrm{n}=10)$, 8-spored, bitunicate, fissitunicate, broadly clavate, with a short pedicel. Ascospores 19-28 $\mu \mathrm{m} \times 7-9 \mu \mathrm{m}(\bar{x}=24.3 \times 8.2$ $\mu \mathrm{m}, \mathrm{n}=10$ ), oblong to ellipsoid, hyaline when young, turning reddish brown at maturity, 4-celled, slightly constricted at the septum, with hyaline at two end cells. Asexual morph: Undetermined.

Material examined - USA, Oahu, Hawaii, Honolulu, Waiahole Ditch Trail, on leaves of Rollandia racemosa (Campanulaceae), 12 June 1921, F.L. Stevens (BISH 499971, isotype).

Economic significance - The fungus in the genus Limaciniopsis is associated with filamentous blue-green algae and is a parasitic fungus on the mycelium (Stevens 1922, Clements 1931).

Linopeltis I. Hino \& Katum., Bull. Faculty of Agriculture, Yamaguchi University 11: 15 (1960)

Epiphytic or saprobic on culms of Sinobambusa tootsik. Sexual morph: Ascostromata scattered, solitary to gregarious, subcuticular or superficial, with hyphae immersed under host tissue, elongate ellipsoidal or irregular in shape, dark brown to black, hemispherical, shiny, glabrous, multi-loculate, with slit-like opening. Locules clustered, globose to subglobose. Peridium composed of a single layer of isodiametric cells, thin-walled, dark brown to black with the base comprising of pseudoparenchymatous cells, arranged in a textura epidermoidea. Hamathecium numerous, filiform, aseptate, broad pseudoparaphyses, embedded in a gelatinous matrix. Asci 8spored, bitunicate, oblong to ellipsoidal, short pedicellate, apically rounded, with indistinct ocular chamber. Ascospores overlapping, fasciculate, firstly hyaline, becoming brown at maturity, cylindrical to elongated fusoid, with marginally rounded ends, distoseptate, 6-10-septate, thick and smooth-walled. Asexual morph: Undetermined.

Type species - Linopeltis ryukyuensis I. Hino \& Katum.

Notes - The genus Linopeltis was introduced by Hino \& Katumoto (1961) with Linopeltis ryukyuensis as the type species. The main characters of the genus are hysterothecial-like ascomata with slit-like openings, oblong to ellipsoidal asci and elongated fusiform to cylindrical, distoseptate ascospores (Phookamsak et al. 2016). The genus was previously placed in Schizothyriaceae by many authors (Von Arx \& Müller 1975, Kirk et al. 2008, Lumbsch \& Huhndorf 2010, Hyde et al. 2013, Wijayawardene et al. 2014). Linopeltis was compared to the genera in Asterinaceae and Aulographaceae in having elongated hysterothecial-like ascomata with slit-like openings (Hyde et al. 2013, Hongsanan et al. 2014, Phookamsak et al. 2016). We examined the holotype specimen of Linopeltis ryukyuensis from YAM herbarium under the code YAM 20332. Linopeltis shares similar morphological similarities to the genus Leptopeltis in having subcuticular or superficial ascostromata, hamathecium comprising numerous broad pseudoparaphyses, bitunicate, cylindrical to cylindric clavate, 8-spored asci. However, the ascospores of the genus Linopeltis are distoseptate, 6-10-septate while that of Leptopeltis is 0-3-septate. We retain the genus Linopeltis in Dothideomycetes, genera incertae sedis until fresh collection and molecular data becomes available. 


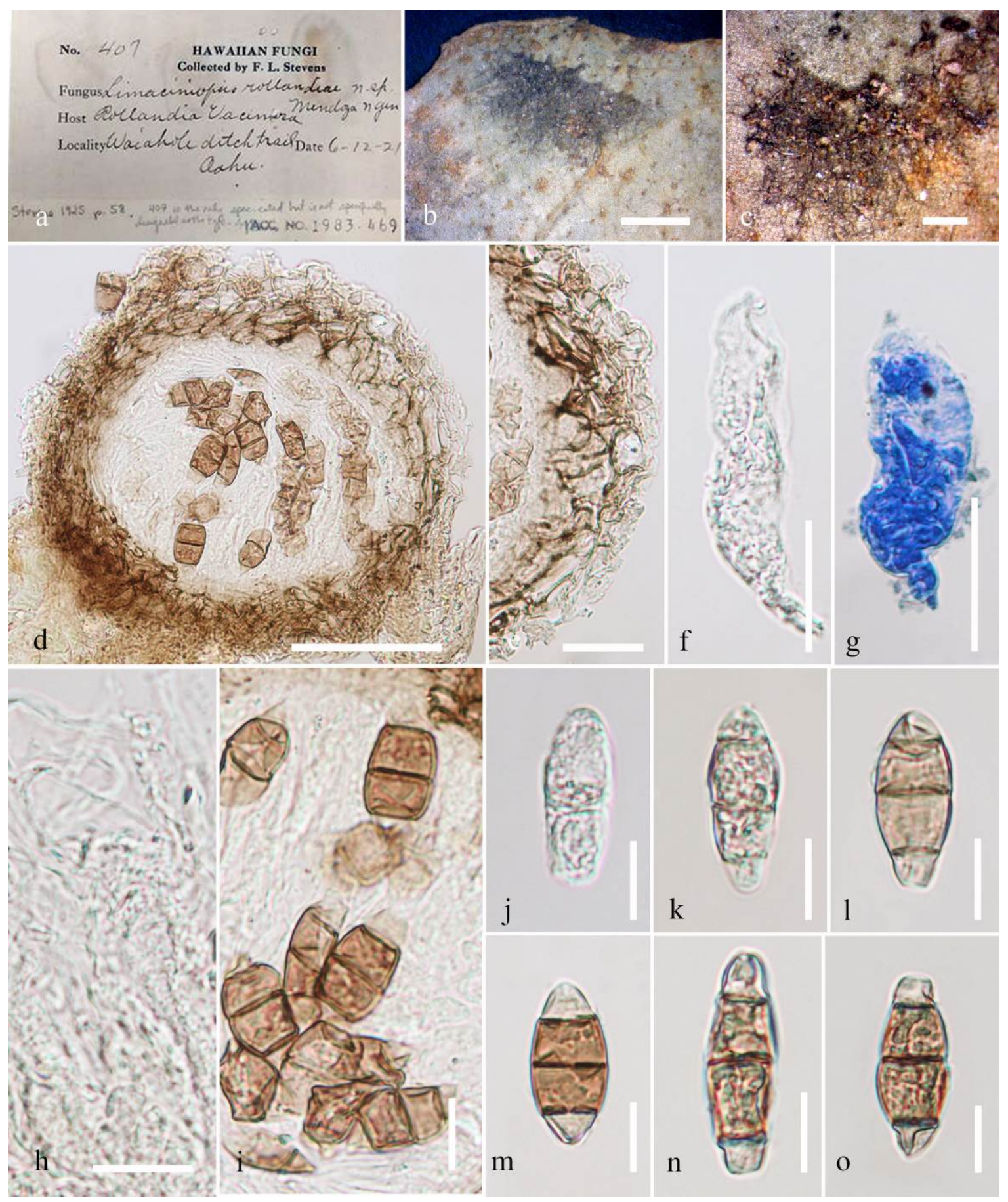

Figure 60 - Limaciniopsis rollandiae (BISH 499971, isotype). a Herbarium material. b, c Appearance of ascomata on host surface. d Section of ascoma. e Peridium. f, g Immature ascospores. h Hamathecium. i Asci. j-o Ascospores. Note: g stained in lactophenol cotton blue. Scale bars: $\mathrm{b}, \mathrm{c}=1 \mathrm{~mm}, \mathrm{~d}=50 \mu \mathrm{m}, \mathrm{e}-\mathrm{g}=20 \mu \mathrm{m}, \mathrm{h}, \mathrm{i}-\mathrm{o}=10 \mu \mathrm{m}$.

Linopeltis ryukyuensis I. Hino \& Katum., Bull. Faculty of Agriculture, Yamaguchi University 11: 15 (1960)

Fig. 61

Index Fungorum number: IF 440969; Facesoffungi number: FoF 01950

Epiphytic or saprobic on culms of Sinobambusa tootsik. Sexual morph: Ascostromata 80-150 $\mu \mathrm{m}$ high, 330-800 $\mu \mathrm{m}$ long, 198-250 $\mu \mathrm{m}$ diam., scattered, solitary to gregarious, subcuticular or superficial, with hyphae immersed under host tissue, elongate ellipsoidal or irregular in shape, dark brown to black, hemispherical, shiny, glabrous, multi-loculate, with slit-like opening. Locules 75$150 \mu \mathrm{m}$ high $\times 60-170 \mu \mathrm{m}$ diam., clustered, globose to subglobose. Peridium 10-20 $\mu \mathrm{m}$ composed 
of a single layer of isodiametric cells, thin-walled, dark brown to black with the base comprising of pseudoparenchymatous cells, arranged in a textura epidermoidea. Hamathecium numerous, filiform, aseptate, broad pseudoparaphyses, embedded in a gelatinous matrix. Asci $45-65 \mu \mathrm{m} \times 20$ $25 \mu \mathrm{m}(\bar{x}=52.5 \times 23.2, \mathrm{n}=10)$, 8-spored, bitunicate, oblong to ellipsoidal, short pedicellate, apically rounded, with indistinct ocular chamber. Ascospores 35-45 $\mu \mathrm{m} \times 3-4 \mu \mathrm{m}(\bar{x}=32.2 \times 3.6$, $\mathrm{n}=10$ ), overlapping, fasciculate, firstly hyaline, becoming brown at maturity, cylindrical to elongated fusoid, with marginally rounded ends, distoseptate, 6-10-septate, thick and smoothwalled. Asexual morph: Undetermined.

Material examined - JAPAN, Okinawa, Nakijinson, Jana Kunigamaigun, on branch of Sinobambusa tootsik (Poaceae), 26 July 1959, H. Muroi (YAM 20332, holotype).

Economic significance - None has been reported.

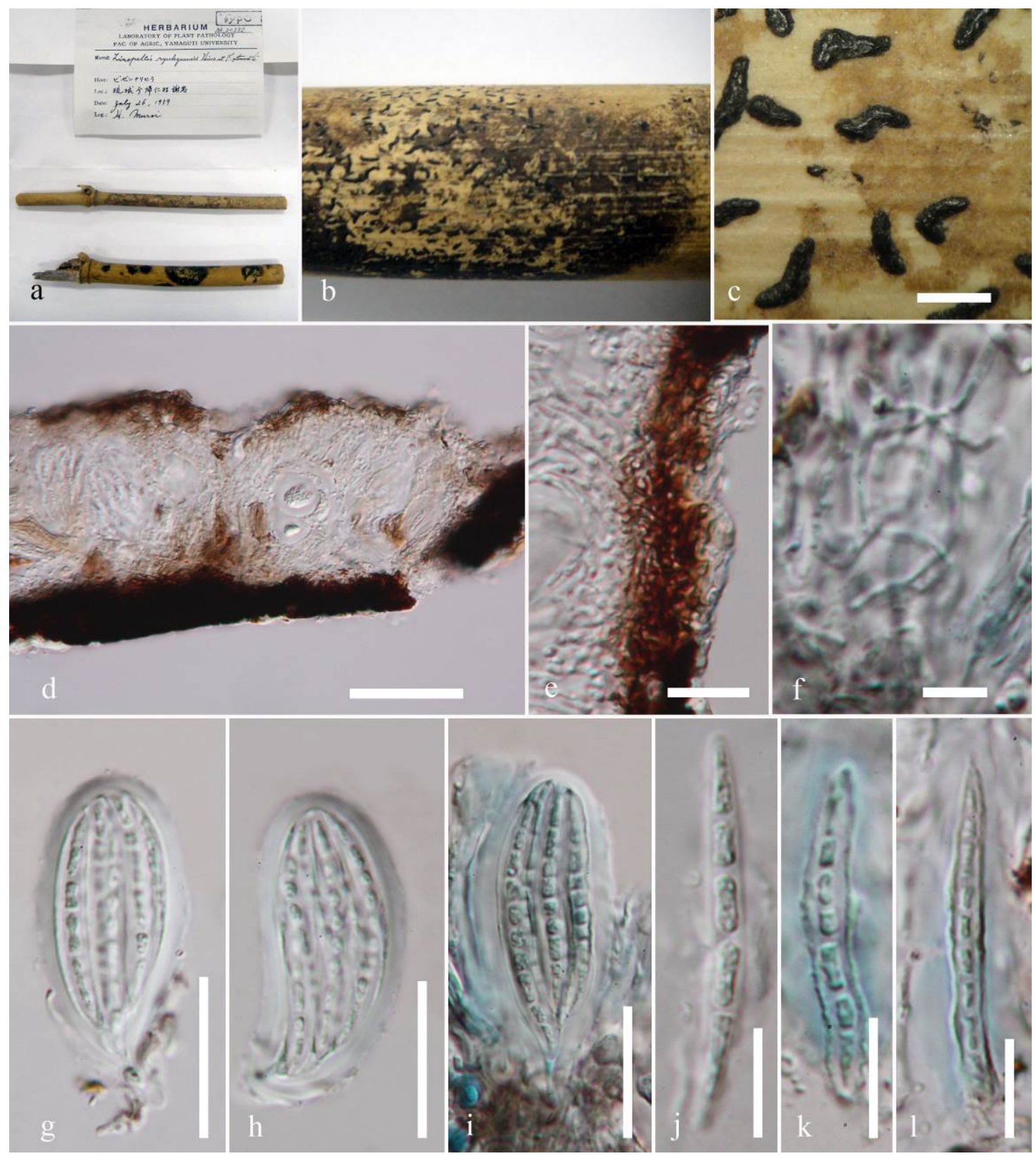

Figure 61 - Linopeltis ryukyuensis (YAM 20332, holotype). a Details of herbarium material. b, c Appearance of ascostromata on the host surface. d Sections through ascostromata. e Section through peridium. f Pseudoparaphyses. g-i Asci. j-l Ascospores. Note: $\mathrm{i}-\mathrm{l}$ stained in lactophenol cotton blue. Scale bars: $\mathrm{c}=100 \mu \mathrm{m}, \mathrm{d}=40 \mu \mathrm{m}, \mathrm{e}, \mathrm{j}-\mathrm{l}=10 \mu \mathrm{m}, \mathrm{f}=5 \mu \mathrm{m}, \mathrm{g}-\mathrm{i}=20 \mu \mathrm{m}$. 
Ascomycota, family incertae sedis

Strangosporaceae S. Stenroos, Miądl. \& Lutzoni

Kullhemia P. Karst., Meddn Soc. Fauna Flora fenn. 2: 182 (1878)

Lichenized on wood. Sexual morph: Thallus crustose, granular, sometimes scurfy, often sparse to absent, scattered, solitary, superficial, grey to blackish. Apothecia biatorine, convex, pulvinate, superficial, gregarious or confluent, black, rarely dull blue-black or black brown, translucent when wet. Apothecial wall composed of hyaline to pale brown cells of textura angularis. Hymenium layer composed of asci and paraphyses, with a crust-like excipulum above. Paraphyses densely anastomosed. Asci clavate, multispored, thick-walled with a distinct ocular chamber. Ascospores globose, simple, thin-walled, hyaline. Asexual morph: Undetermined.

Type species - Kullhemia moriformis (Ach.) P. Karst.

Notes - The genus Kullhemia was introduced by Karst in 1878 with the type species $K$. moriformis. There are two epithets under the genus Kullhemia in Index Fungorum (2019). Cultures and sequences are unavailable. The genus Kullhemia and Strangospora share similarities such as a lichenized habit, bitunicate, wedge-shaped asci and aseptate hyaline ascospores. The genus Strangospora is in the subphylum Pezizomycotina, Strangosporaceae, families incertae sedis (Lucking et al. 2016, Doilom et al. 2018). We therefore synonymize the genus Kullhemia under Strangospora and exclude it from Dothideomycetes, genera incertae sedis.

Kullhemia moriformis (Ach.) P. Karst., Meddn Soc. Fauna Flora fenn. 2: 183 (1878)

Fig. 62

三Arthonia moriformis Ach., Syn. meth. lich. (Lund): 5 (1814)

Index Fungorum number: IF 156835; Facesoffungi number: FoF 06207

Current name: Strangospora moriformis (Ach.) Stein, in Cohn, Krypt.-Fl. Schlesien (Breslau) 2(2): 176 (1879)

Saprobic on unidentified wood. Sexual morph: Thallus crustose, granular, sometimes scurfy, often sparse to absent, scattered, solitary, superficial, grey to blackish. Apothecia 257-405 $\mu \mathrm{m}$ high $\times$ 270-367 $\mu \mathrm{m}$ diam., $(\bar{x}=327.5 \times 310.9 \mu \mathrm{m}, \mathrm{n}=10)$, biatorine, convex, pulvinate, superficial, gregarious or confluent, black, rarely dull blue-black or black brown, translucent when wet. Apothecial wall 10-19 $\mu \mathrm{m}$ wide, composed of hyaline to pale brown cells of textura angularis. Hymenium layer composed of asci and paraphyses, with a crust-like excipulum above. Paraphyses densely anastomosed. Asci 35-50 $\mu \mathrm{m} \times 13-18 \mu \mathrm{m}(\bar{x}=41.9 \times 14.0 \mu \mathrm{m}, \mathrm{n}=10)$, clavate, multispored, thick-walled with a distinct ocular chamber. Ascospores 1.9-2.3 $\mu \mathrm{m} \times 1.8-2.4 \mu \mathrm{m}$ $(\bar{x}=2.1 \times 2.0 \mu \mathrm{m}, \mathrm{n}=10)$, globose, simple, thin-walled, hyaline. Asexual morph: Undetermined.

Material examined - USA, Minnesota, Tower, on unidentified wood, 29 August 1901, B. Fink (MICH 126713).

Economic significance - The genus Kullhemia consist of lichenized species. There is no molecular data available for the taxon.

Sordariomycetes O.E. Erikss. \& Winka

Chaetothyriales, family incertae sedis

Bahusutrabeeja Subram. \& Bhat, Can. J. Bot. 55(16): 204 (1977)

Saprobic on dead stems, twigs, leaves and branches. Sexual morph: undetermined. Asexual morph: Hyphomycetous. Mycelium hairy, medium dense, partly immersed, partly superficial, composed of thin, branched, septate, smooth-walled, light brown 2-3 $\mu$ m hyphae. Setae and hyphopodia absent. Conidiophores distinct, macronematous, mononematous, solitary, erect, straight or slightly flexuous, septate, unbranched, rarely branched, cylindrical, smooth, thickwalled, dark reddish brown near the base, light brown in the apical part. Conidiogenous cells monophialidic, terminal, integrated, light brown, smooth, with a conspicuous flared, colarrette at the tip. Conidia solitary, simple, slimy, endogenous, hyaline, aseptate, smooth, thick-walled, rounded-cubical to polygonal, spherical to obovoid, hyaline to sub-hyaline, with flexuous, thin, hyaline appendages distributed all over the surface. 

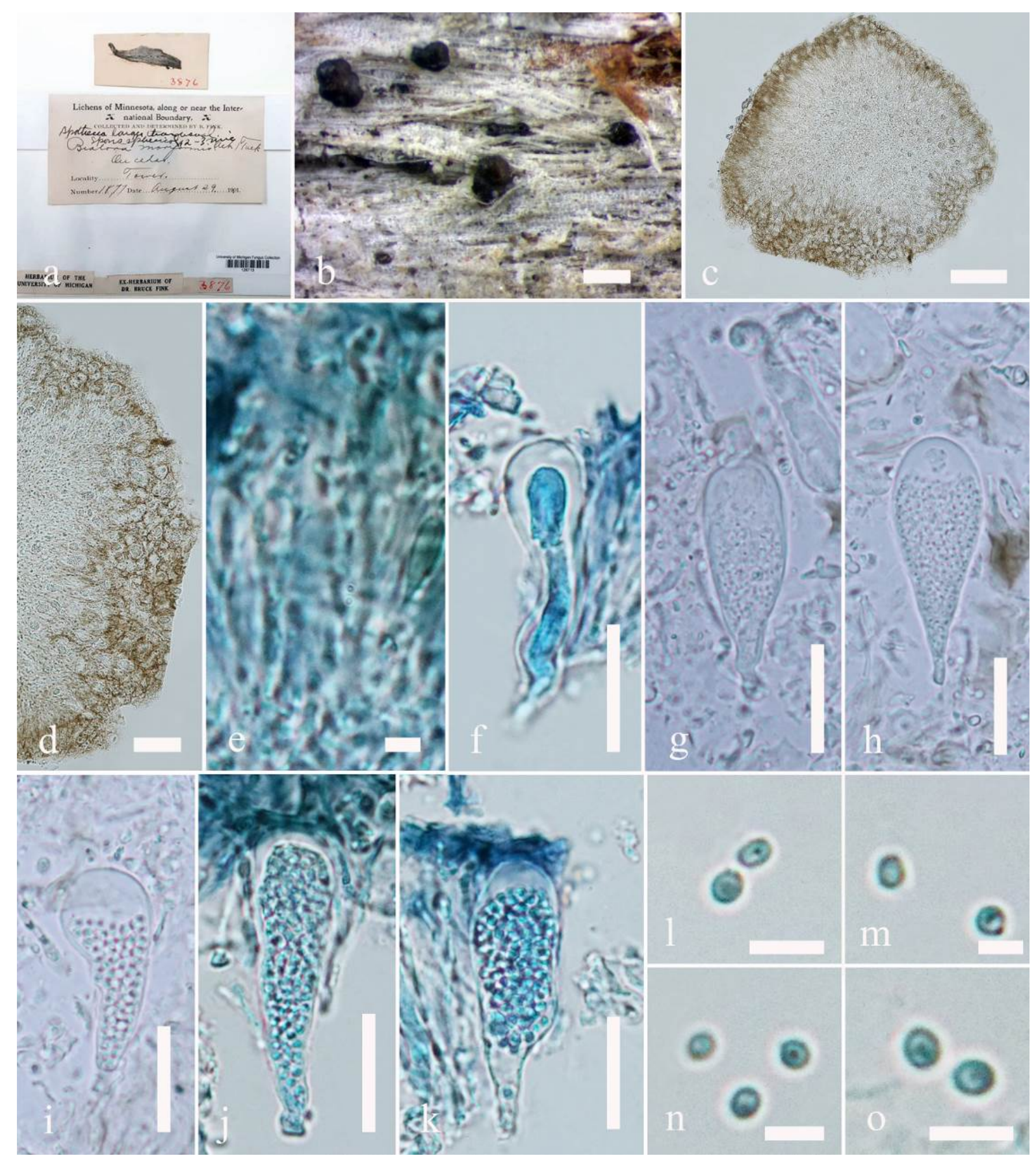

Figure 62 - Kullhemia moriformis (MICH 126713) a Details of herbarium material. b Habit and appearance of ascomata on host surface. c Section of ascoma. d Peridium. e Hamathecium. f-k. Asci. l-o Ascospores. Note: e-o stained in lactophenol cotton blue. Scale bars: $b=500 \mu \mathrm{m}, \mathrm{c}=100$ $\mu \mathrm{m}, \mathrm{d}=50 \mu \mathrm{m}, \mathrm{e}, \mathrm{m}, \mathrm{n}=5 \mu \mathrm{m}, \mathrm{f}-\mathrm{k}=20 \mu \mathrm{m}, \mathrm{l}, \mathrm{o}=10 \mu \mathrm{m}$.

Type species - Bahusutrabeeja dwaya Subram. \& Bhat

Notes - The genus Bahusutrabeeja was introduced by Subramanian \& Bhat (1977) with Bahusutrabeeja dwaya Subraman. \& Bhat as the type species. Bahusutrabeeja dwaya was isolated from dead twigs of Coffea arabica L. from India. Currently, five species are accommodated in the genus Bahusutrabeeja including B. angularis V.G. Rao \& de Hoog, B. bunyensis McKenzie, B. dubhashii Bhat, B. exappendiculata Xiao X. Li \& X.G. Zhang and B. globosa Bhat \& W.B. Kendr.. Li et al. (2013) provided a key to species in the genus. The sexual morph is unknown. In a DNA based phylogenetic study conducted by Shenoy et al. (2010), the genus Bahusutrabeeja clustered in the Botryosphaeriales. It is currently placed in Botryosphaeriales, genera incertae sedis (Wijayawardene et al. 2018). However, in a study of Botryospheriales by Liu et al. (2012), Phillips 
et al. (2013) and Yang et al. (2016), there is no mention of the genus Bahusutrabeeja. We restudied a specimen of $B$. dwaya and illustrated the characters (Fig. 13). We also conducted phylogenetic analyses using the putative strain of Bahusutrabeeja (GUFCC 4904). The LSU sequence from GUFCC 4904 corresponds to Neodeightonia palmicola. However, this strain is not related to the holotype and not supported by morphology. Species of Neodeightonia are characterized by spherical to globose, initially hyaline and pale to dark brown conidia with fine striations (Punithalingam 1969, Crous et al. 2006, Phillips et al. 2008, Phillips et al. 2013). However, in the genus Bahusutrabeeja, conidia are hyaline to sub-hyaline with appendages distributed all over the surface. Also, Bahusutrabeeja is a hyphomycetous genus, while species of Neodeightonia and Botryosphaeriaceae are coelomycetous. It is unlikely to place a hyphomycetous genus within the Neodeightonia clade. It seems that there must have been a mix-up of cultures and this isolate is not reliable. On the other hand, a BLAST search using the ITS sequence of CBS 261.77, the ex-type culture of Bahusutrabeeja dwaya shows 92 to $96 \%$ similarity to the strains of Chaetosphaeriales sp. in the Sordariomycetes. We therefore transfer the genus Bahusutrabeeja to Chaetothyriales, family incertae sedis.

Bahusutrabeeja dwaya Subram. \& Bhat, Can. J. Bot. 55(16): 2204 (1977)

Fig. 63, 64

Index Fungorum number: IF 309440; Facesoffungi number: FoF 06218

Saprobic on dead twigs of Coffea arabica L. Sexual morph: undetermined. Asexual morph: Hyphomycetous. Mycelium hairy, medium dense, partly immersed, partly superficial, composed of thin, branched, septate, smooth-walled, light brown 2-3 $\mu$ m wide hyphae. Setae and hyphopodia absent. Conidiophores 41-90 $\mu \mathrm{m} \times 3-6 \mu \mathrm{m}(\bar{x}=57.3 \times 4.2 \mu \mathrm{m}, \mathrm{n}=20)$, distinct, single, macronematous, mononematous, solitary, erect, straight or slightly flexuous, septate, unbranched, rarely branched, cylindrical, smooth, thick-walled, dark reddish brown near the base, light brown in the apical part. Conidiogenous cells monophialidic, terminal, integrated, light brown, smooth, with a conspicuous colarrette, $2 \mu \mathrm{m}$ long, $4 \mu \mathrm{m}$ wide at the tip. Conidia 9-15 $\mu \mathrm{m} \times 10-15 \mu \mathrm{m}(\bar{x}=12.6$ $\times 11.4 \mu \mathrm{m}, \mathrm{n}=10$ ), solitary, simple, slimy, endogenous, hyaline, aseptate, smooth, thick-walled, rounded-cubical to polygonal, spherical to obovoid, hyaline to sub-hyaline, with 8-12 $\mu \mathrm{m}$ flexuous, thin, 7-11 $\mu \mathrm{m}$ long, hyaline appendages distributed all over the surface.

Material examined - INDIA, Tamil Nadu. On dead twigs of Coffea arabica, (Rubiaceae), 25 May 1977, C.V. Subramanian (K (M) 213921).

Economic significance - The genus Bahusutrabeeja has been reported on leaf litter of various hosts (Paulus 2004). Bahusutrabeeja dwaya is also pathogenic causing amphigenous brown spots on living leaves of Mallotus philippinensis Muell. (Euphorbiaceae) (Wu et al. 2003).

Xylariales, genus incertae sedis

Botryohypoxylon Samuels \& J.D. Rogers, Mycotaxon 25(2): 631 (1986)

三Iledon Samuels \& J.D. Rogers, Mycotaxon 25(2): 633 (1986)

Parasitic or lignicolous on trunks of dead tree. Sexual morph: Ascostromata rarely solitary, often cespitose in groups of 2-20 ascomata, ostiolate. Each ascoma arise on a cylindrical pedestal, globose with a tiny, acute papilla, only slightly wider than the pedestal, smooth, not collapsing when dry. Peridium with three discrete regions; outer region composed of cells of textura angularis, with long axes perpendicular to the surface of the ascomatal wall, individual cells with pigmented walls; middle region composed of cells of textura epidermoidea; inner region, the eel is fusoid, non- pigmented. Ascomatal apex composed of intertwined hyphae with lumens and pigmented with finger-like periphyses. Paraphyses forming a network between the asci, copious, branching, anastomosing, free ends not seen. Asci clavate, ascal cytoplasm abruptly narrowed below the ascospores at the point of dehiscence, dehiscing at the midpoint, forming a hymenium over the entire interior of the ascomatal wall, unitunicate with thin ectoascus and endoascus rather thick throughout the entire length of the ascus. Ascospores unicellular, hyaline when immature, dark brown, nearly opaque when mature, ellipsoidal. Asexual morph: Undetermined. 


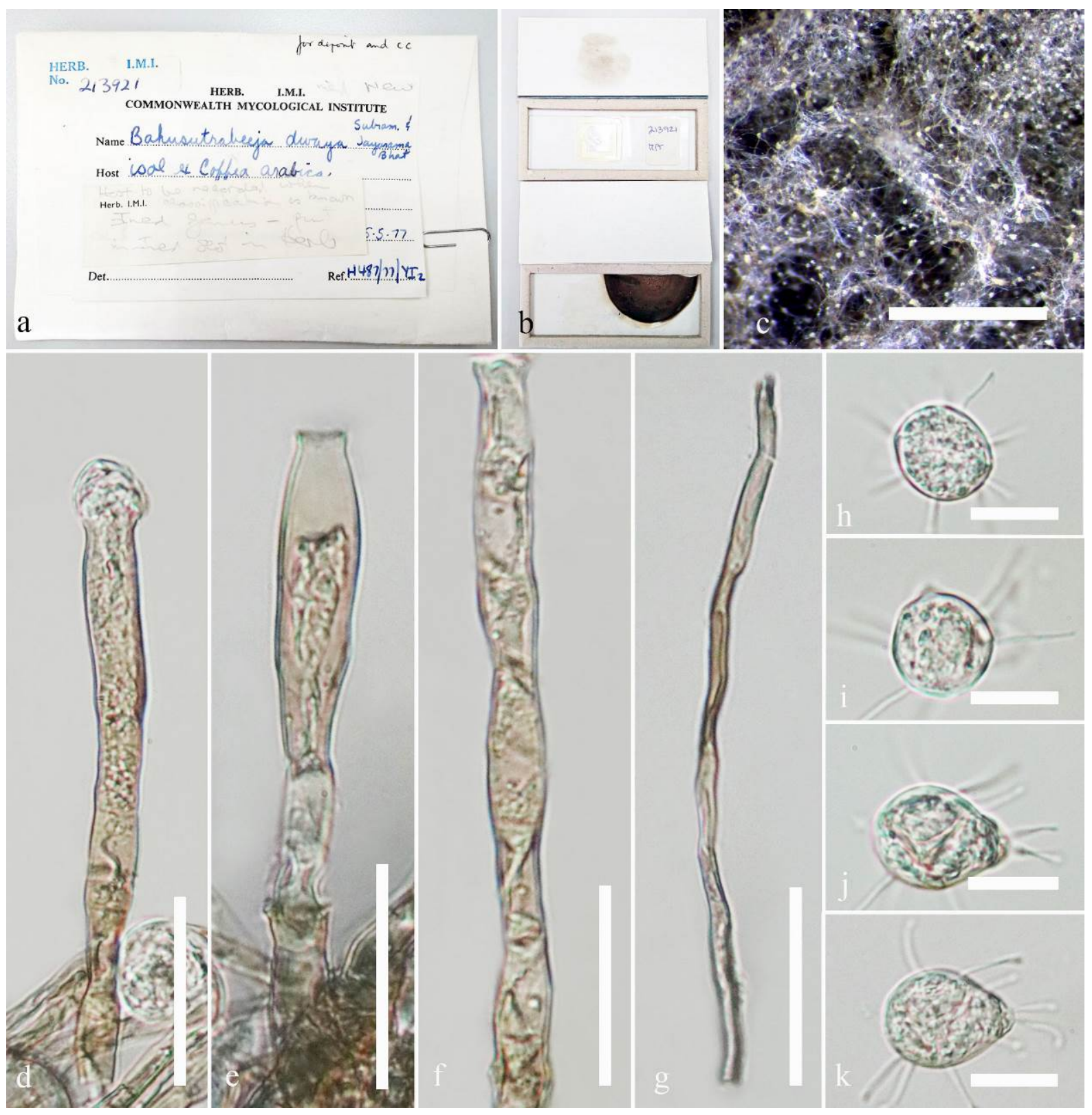

Figure 63 - Bahusutrabeeja dwaya (K (M) 213921). a, b Details of herbarium material. c mycelium on dry culture. $\mathrm{d}-\mathrm{g}$. Conidiophores. $\mathrm{h}-\mathrm{k}$ Conidia. Scale bars: $\mathrm{c}=1 \mathrm{~mm}, \mathrm{~d}-\mathrm{g}=20 \mu \mathrm{m}, \mathrm{h}-$ $\mathrm{k}=10 \mu \mathrm{m}$.

Type species - Botryohypoxylon amazonense Samuels \& J.D. Rogers

Notes - Samuels \& Rogers (1986) described the monotypic genus Botryohypoxylon with the type species B. amazonense, collected on trunks of dead trees in Amazonian Venezuela. Morphologically, this genus is distinct in its massive erumpent stroma which is accompanied by 'eustromatic' pycnidia with apparent phialides, unicellular ascospores, clavate, short-stipitate asci with a thin ectotunica and a thick endotunica, hamathecium consisting somewhat wide and branched pseudoparaphyses without free ends. The coelomycetous asexual state was observed in culture and described as Iledon. Botryohypoxylon is congeneric with Iledon (Index Fungorum 2019). Priority to the older sexual state was anticipated by Wijayawardene et al. (2014) and they proposed to use Botryohypoxylon over Iledon. The original author described Botryohypoxylon as unusual among bitunicate ascomycetes in having dark unicellular ascospores termed as an inconspicuous elongated germ-slit and has been found to have somewhat similar characteristics as Semidelitschia agasmatica (Cain \& Luck-Allen 1969) and Loculohypoxylon grandineum (Berk \& Rav.) Barr (Barr 1976). However, we re-examined the type specimen of Botryohypoxylon 
amazonense under the code NY02980804 and found that Botryohypoxylon has unitunicate rather than bitunicate asci. We therefore transfer the genus Botryohypoxylon to Xylariales, genera incertae sedis.
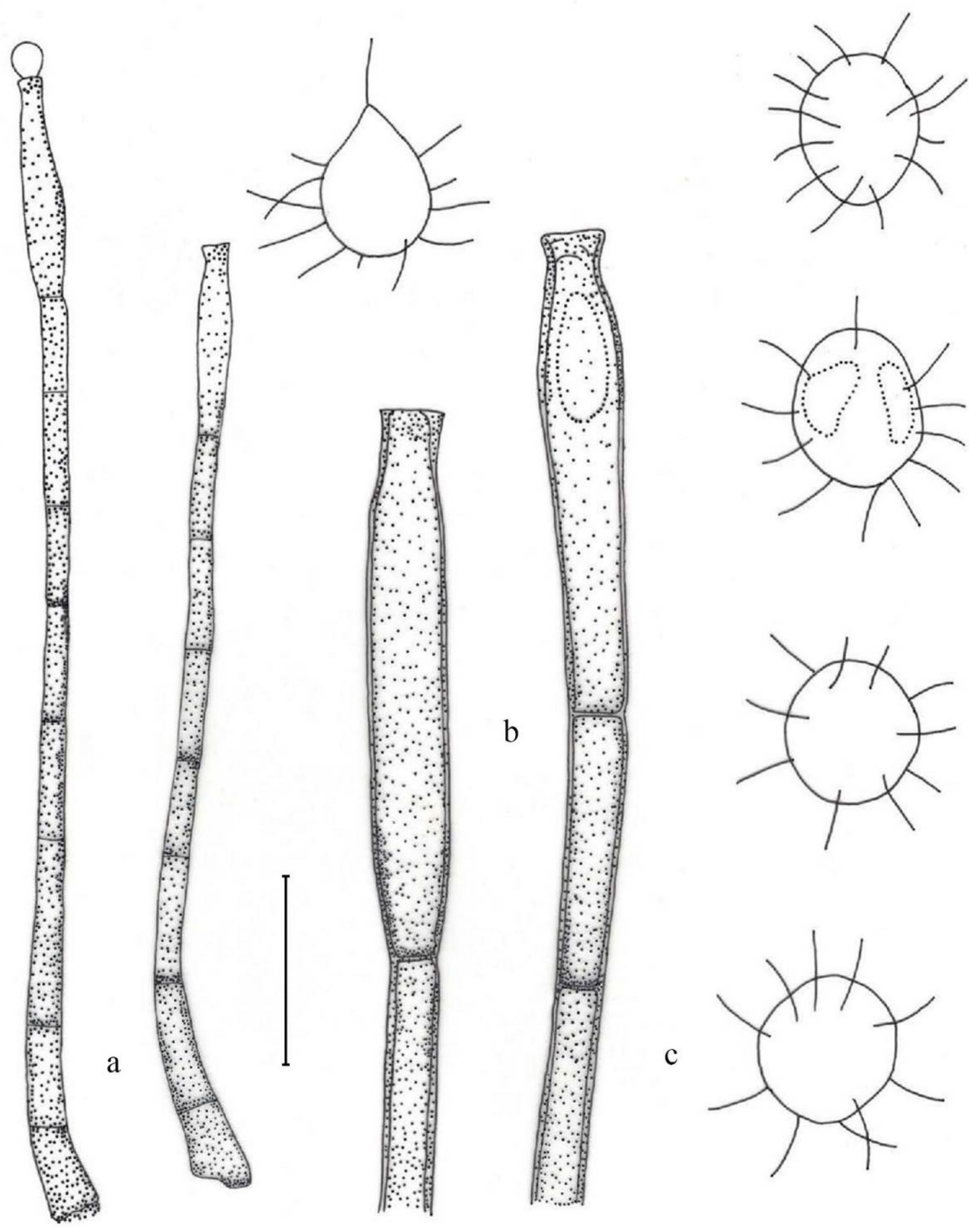

Figure 64 - Bahusutrabeeja dwaya (redrawn from Wu et al. 2003). a, b. Conidiophores and conidiogenous cells. c. Conidia. Scale bars: $\mathrm{a}=50 \mu \mathrm{m}, \mathrm{b}, \mathrm{c}=20 \mu \mathrm{m}$.

Botryohypoxylon amazonense Samuels \& J.D. Rogers, Mycotaxon 25(2): 633 (1986)

Fig. 65

Index Fungorum number: 214383; Facesoffungi number: FoF 06221

Parasitic or lignicolous on dead trunks of tree. Sexual morph: Ascostromata rarely solitary, often cespitose in groups of 2-20, individually $600-700 \mu \mathrm{m}$ diam. with locule $550 \mu \mathrm{m}$ diam, 
ostiolate, thickened subiculum. Each ascoma arise on a cylindrical $1 \mathrm{~mm}$ long $\times 0.5 \mathrm{~mm}$ wide pedestal, globose with a tiny, acute papilla, only slightly wider than the pedestal, smooth, not collapsing when dry. Peridium $130 \mu \mathrm{m}$ thick, with three discrete regions. Outer region 26-37 $\mu \mathrm{m}$ wide, composed of cells of textura angularis, with long axes perpendicular to the surface of the ascomatal wall, individual cells 7-9 $\mu \mathrm{m}$ in greatest dimension with pigmented walls 1-2 $\mu \mathrm{m}$ thick. Middle region 25-35 $\mu \mathrm{m}$ wide, composed of cells of textura epidermoidea. Inner region 10-20 $\mu \mathrm{m}$ wide, the eel is fusoid, non- pigmented. Ascomatal apex composed of intertwined hyphae with lumens 1-2 $\mu \mathrm{m}$ wide and $3 \mu \mathrm{m}$ thick and pigmented with finger-like periphyses. Pseudoparaphyses $2 \mu \mathrm{m}$ wide, forming a network between the asci, copious, branching, anastomosing, free ends not seen. Asci 51-85 $\mu \mathrm{m} \times 6-9 \mu \mathrm{m}(\bar{x}=65.8 \times 8.0, \mathrm{n}=20)$, 8-spored, unitunicate with thin ectoascus and endoascus rather thick throughout the entire length of the ascus, clavate, ascal cytoplasm abruptly narrowed below the ascospores at the point of dehiscence, dehiscing at the midpoint, forming a hymenium over the entire interior of the ascomatal wall. Ascospores 6.7-7.9 $\mu \mathrm{m} \times 4.3-$ $5.0 \mu \mathrm{m}(\bar{x}=7.1 \times 4.5, \mathrm{n}=20)$, uni to biseriate, ellipsoidal, unicellular, hyaline when immature, dark brown, nearly opaque when mature, smooth-walled. Asexual morph: Undetermined.

Material examined - VENEZUELA, on trunks of dead tree (Leguminosae), along Rio

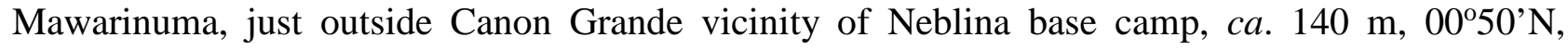
$66^{\circ} 10^{\prime} \mathrm{W}$; low primary forest on white sand, 30 April 1984, Gary J. Samuels (1703) \& W. Thomas, (NY02980804, holotype).

Economic significance - The genus Botryohypoxylon is parasitic or possibly lignicolous on trees in Amazonian Venezuela. No other economic significance havehas been reported (Samuels \& Roger 1986).

\section{Sporocadaceae Corda 1842}

Dilophospora Desm., Annls Sci. Nat., Bot., sér. 2 14: 6 (1840)

Pathogenic on the surface of living leaves. Sexual morph: Undetermined. Asexual morph: Conidiomata stromatic, varying from pycnidioid to indeterminate, subepidermal, immersed, uni- to plurilocular, locules sometimes tortuous, dark brown to brown, glabrous, wall of textura angularis or textura globulosa, occasionally of textura prismatica, cells thick-walled, dark brown to brown in the outer layers, becoming thin-walled and paler towards the conidial hymenium. Conidiophores ascending from the inner layers lining the conidioma, or at the base and extending part way up the side walls, rarely septate and intermittently branched, frequently reduced to conidiogenous cells. Conidiogenous cells hyaline, thin-walled, smooth, with percurrent proliferations, and with apical periclinal thickenings. Conidia cylindrical to fusoid with an acute or blunt apex and a truncate base, straight or slightly curved, 3-4-euseptate, with hyaline apical cell, other cells hyaline, with smooth wall, with or without constrictions at septa, with multiple apical appendages, each arising as a tubular extension of the apical cell, not separated from a septum, appendages with 2-4 narrow, attenuated, flexuous, divergent branches, basal appendage tubular, single, branched, exogenous, filiform, flexuous.

Type species - Dilophospora alopecuri (Fr.) Fr.

Notes - The asexual genus Dilophospora was introduced by Desmazières (1840) for the pathogenic fungus $D$. graminis ( $=D$. alopecuri) occurring on wide range of grasses in Europe and previously described by Fries (1828) under the name Sphaeria alopecuri. This was followed by Grove (1935). Later, the species was transferred to the genus Dilophospora under the name of Dilophosphora alopecuri Fries. The genus is characterized by stromatic conidiomata, a conidiomatal cell wall of textura angularis, conidiophores with percurrent proliferations and cylindrical to fusoid conidia with an acute or blunt apex and a truncate base with multiple apical appendages. Currently, two species are accepted in the genus. The sexual morph is unknown. Cultures and sequences are unavailable. An examination of the specimen and descriptions of Dilophospora alopecuri is provided below. The species in the genus Dilophospora are similar to those in Sporocadaceae in having unique appendage bearing conidia. The stromatic conidiomata, peridium of textura globulosa and textura prismatica of Dilophospora alopecuri fits well with 
species in Sporocadaceae. Therefore, based on various morphological similarities, we place the genus Dilophospora in Sporocadaceae (Amphisphaeriales, Sordariomycetes).

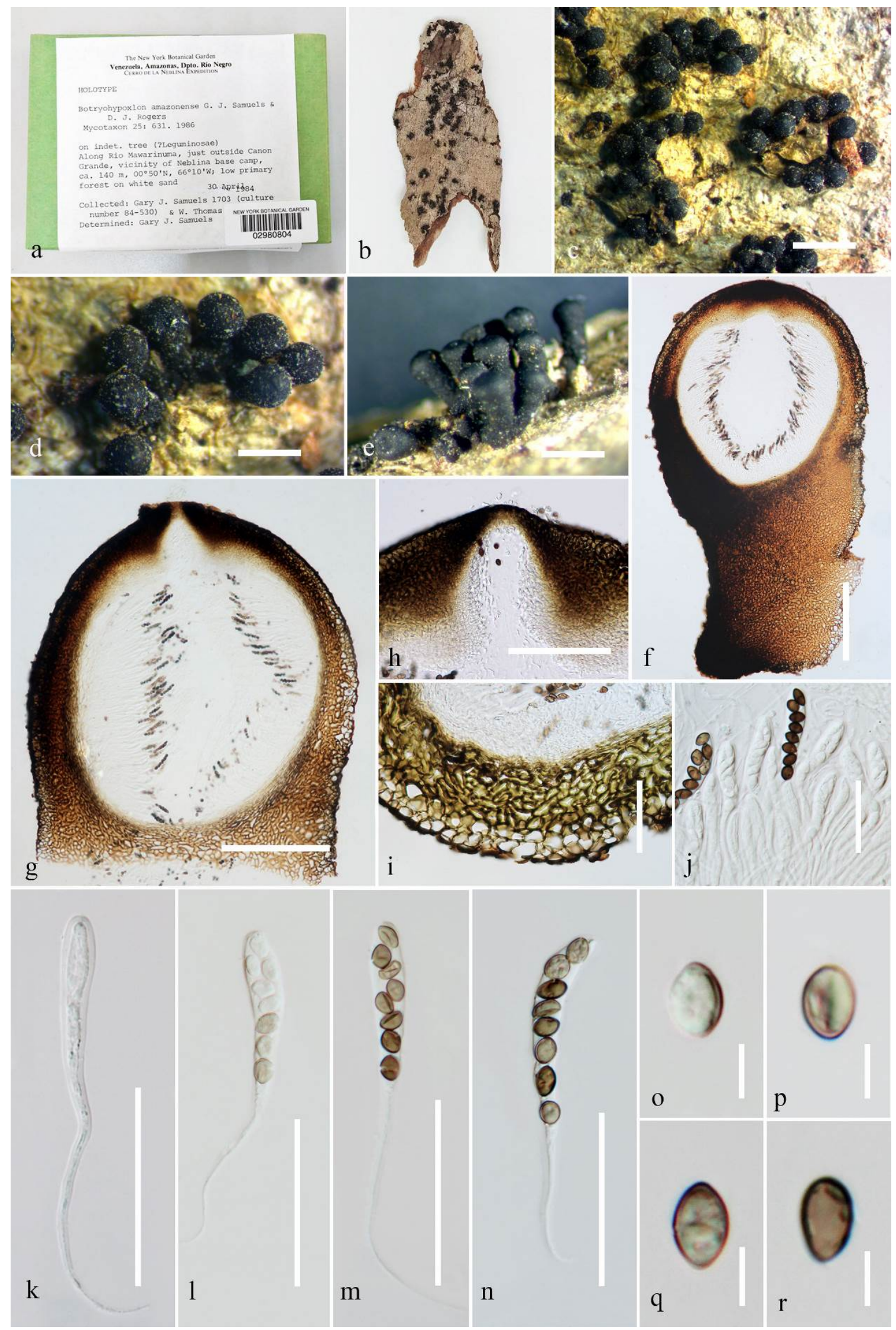

Figure 65 - Botryohypoxylon amazonense (NY02980804, holotype) a, b Herbarium specimen and habit on trunks of dead tree. c-e Appearance of ascomata on host surface. f Median longitudinal 
section through a mature ascomata. g Section of ascomata. h Ostiole. i Peridium. j Asci with branching pseudoparaphyses. $\mathrm{k}-\mathrm{m}$ Asci. $\mathrm{n}$ Dehisced bitunicate ascus, arrow indicates the point of dehiscence. o-r Ascospores, arrows indicate spores that have visible germination sites or germ-slit. Scale bars: $\mathrm{c}-\mathrm{e}=500 \mu \mathrm{m}, \mathrm{g}-\mathrm{h}=100 \mu \mathrm{m}, \mathrm{i}-\mathrm{n}=50 \mu \mathrm{m}$.

Dilophospora alopecuri (Fr.) Fr., Summa veg. Scand., Sectio Post. (Stockholm): 419 (1849)

Fig. 66

इ Sphaeria alopecuri Fr., Elench. fung. (Greifswald) 2: 90 (1828)

Index Fungorum number: IF 182994; Facesoffungi number: FoF 06234

Pathogenic on the surface of living leaves of Festuca rubra. Sexual morph: Undetermined. Asexual morph: Conidiomata 230-390 $\mu \mathrm{m}$ high $\times$ 373-599 $\mu \mathrm{m}$ diam., stromatic, varying from pycnidioid to indeterminate, subepidermal, immersed, uni- to plurilocular, dark brown to brown, glabrous. Pycnidial wall 16-35 $\mu \mathrm{m}$ consists of two layers, thick outer wall of brown textura globulosa, and inner layer of paler brown to hyaline textura prismatica. Conidiophores ascending from the inner layers lining the conidioma, or at the base and extending part way up the side walls, lightly septate and intermittently branched, frequently reduced to conidiogenous cells, hyaline, thin and smooth-walled, with percurrent proliferations, and apical periclinal thickenings. Conidia 11-15 $\mu \mathrm{m} \times 1-2 \mu \mathrm{m}(\bar{x}=12.7 \times 1.9 \mu \mathrm{m}, \mathrm{n}=20)$, cylindrical to fusoid with an acute or blunt apex and a truncate base, straight or slightly curved, 3-4 euseptate, apical cell hyaline, other cells hyaline, smooth-walled, with or without constrictions at septa, apical appendage multiple, arising as a tubular extension of the apical cell and not separated from it by a septum, with 2-4 narrow, attenuated, flexuous, divergent branches, basal appendage tubular, single, branched, exogenous, filiform, flexuous.

Material examined - SWEDEN, Knivsta, Uppsala County, on leaves of Festuca rubra (Poaceae), June 1876, G. Löfgren (S-F44045).

Economic significance - Species of the genus Dilophosphora are plant pathogens. Dilophospora alopecuri can infect rye, wheat and other cereals (Barbetti \& Riley 2006). The species relies on a nematode species of the genus Anguina to spread by their conidia, adhering to the hosts and infect plants directly leading to leaf spots and distortions (Asad et al. 2007). The mycelium can enter developing seeds making them unsuitable for cultivation (Bird 1987). Dilophospora alopecuri also has potential as a biopesticide for the management of annual rye grass toxicity (Yan \& Riley 2005).

\section{Sordariomycetes genera incertae sedis}

Hassea Zahlbr., Beih. Botan. Centralbl. 13: 150 (1902)

Lichenicolous on the rock. Sexual morph: Ascomata perithecial, subglobose to applanate, carbonaceous, black, smooth or rough, semi-immersed or superficial in the thallus of the host, ostiolate, with a central ostiole located in a papilla; singly scattered or more rarely crowded in small groups, slightly glistening. Peridium continuous, composed of three layers: an inner excipular layer and two outer involucrellum layers; extemal involucrellum layer is carbonaceous, consisting of isodiametric, thick-walled cells, with enlarged lumina and black walls; intemal involucrellum layer is colorless to black, paraplectenchymatous, consisting of isodiametric, thin-walled cells, with enlarged lumina and a colorless to pigmented wall; intemal involucrellum layer is thicker than the extemal one; excipular layer: thinner, hyaline, composed of cells becoming laterally compressed, with thin, colorless walls and enlarged lumina. Hamathecium composed of paraphyses and periphyses. Paraphyses septate, simple and poorly branched becoming evanescent, branched, hymenial gelatineous. Asci elongate claviform to cylindrical, shortly stalked, unitunicate, thinwalled, slightly thickened at the apex of young asci, 8-spored. Ascospores overlapping in the ascus, simple, cylindrical to filiform, one or more transverse septa, not constricted at the septa, thin-walled without mucilaginous sheath. Asexual morph: Undetermined.

Type species - Hassea bacillosa (Nyl.) Zahlbr. 


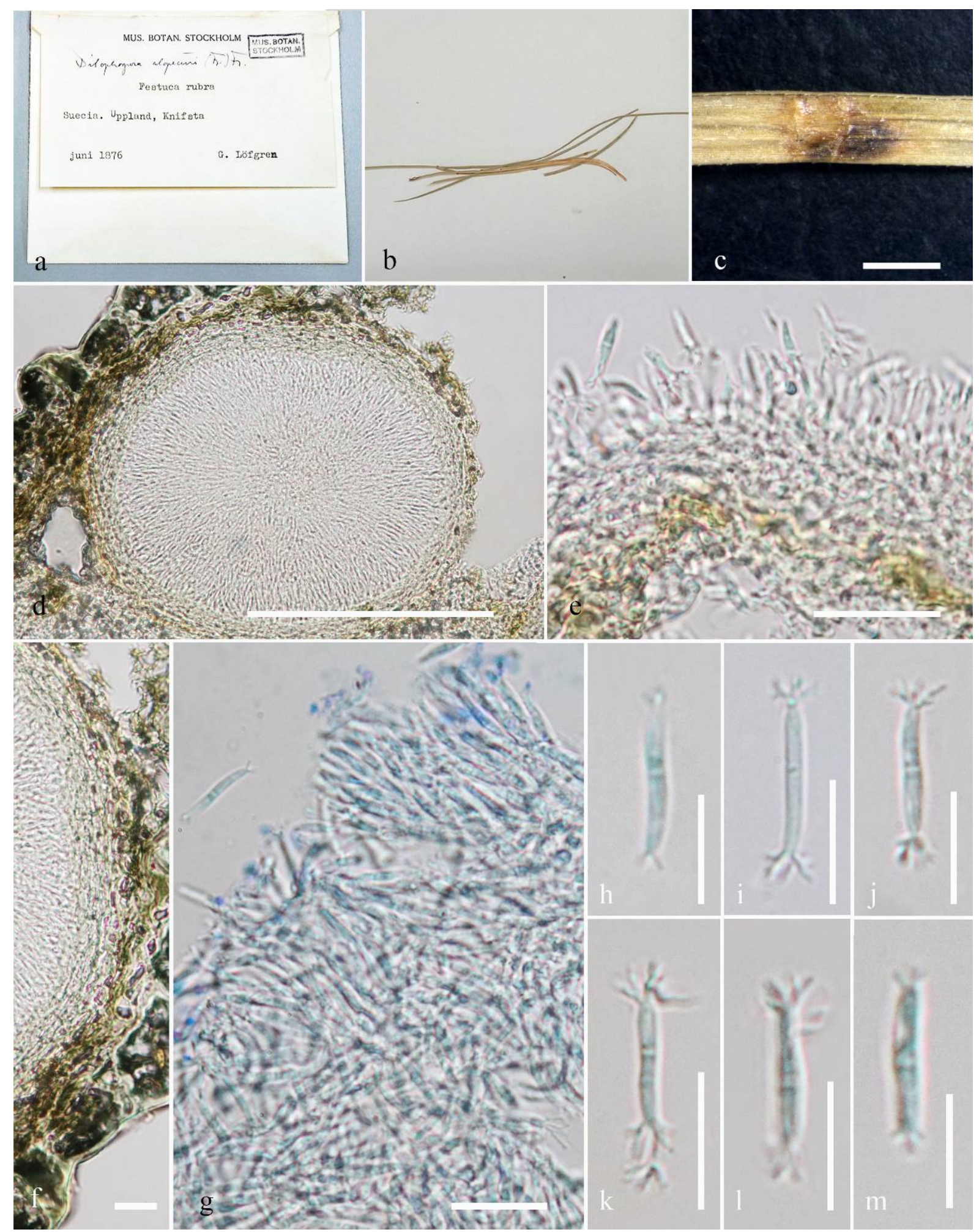

Figure 66 - Dilophospora alopecuri (F44045). a Details of herbarium material. b, c Habit and appearance of ascomata on host surface. d Section of conidioma. e Conidiogenesis. f Peridium. $g$ Conidia. $\mathrm{h}-\mathrm{m}$ Conidia. Note: $\mathrm{g}-\mathrm{m}$ stained in lactophenol cotton blue. Scale bars: $\mathrm{c}=1 \mathrm{~mm}, \mathrm{~d}=200$ $\mu \mathrm{m}, \mathrm{e}, \mathrm{g}=20 \mu \mathrm{m}, \mathrm{f}, \mathrm{h}-\mathrm{m}=10 \mu \mathrm{m}$.

Notes - Hassea was introduced by Zahlbruckner (1902) to accommodate the type species $H$. bacillosa (Nyl.) Zahlbr. and is characterised by perithecial ascomata, elongate claviform to cylindrical unitunicate asci and hyaline, cylindrical-bacilliform ascospores. Hassea was included as a genus in Dothideomycetes genera incertae sedis (Lumbsch \& Huhndorf 2010, Kirk et al. 2013, Wijayawardene et al. 2018). The asexual morph is unknown. Cultures and sequences are 
unavailable for the type species. We re-examined the type specimen Hassea bacillosa from $\mathrm{FH}$ under the code FH 00213640. Based on its morphology Hassea could not be accommodated in any of the family in the class Dothideomycetes. We therefore, transfer the genus Hassea to Sordariomycetes genera incertae sedis based on its claviform to cylindrical unitunicate asci.

Hassea bacillosa (Nyl.) Zahlbr., Beih. Botan. Centralbl. 13: 150 (1902)

Fig. 67

三Verrucaria bacillosa Nyl., Lichens of South California, edn 2: 20 (1898)

Index Fungorum number: IF 386699; Facesoffungi number: FoF 06246

Lichenicolous on the rock. Sexual morph: Ascomata 275-295 $\mu \mathrm{m}$ high $\times 235-275 \mu \mathrm{m}$ diam., perithecial, subglobose to applanate, carbonaceous, black, smooth or rough, semi-immersed or superficial in the thallus of the host, ostiolate, with a central ostiole located in a papilla; singly scattered or more rarely crowded in small groups, slightly glistening. Peridium 18-45 $\mu \mathrm{m}$ continuous, composed of three layers: an inner excipular layer and two outer involucrellum layers; extemal involucrellum layer carbonaceous, consisting of isodiametric, thick-walled cells, with enlarged lumina and black walls; intemal involucrellum layer colorless to black, paraplectenchymatous, consisting of isodiametric, thin-walled cells, with enlarged lumina and a colorless to pigmented wall; intemal involucrellum layer thicker than the extemal one; excipular layer: thinner, hyaline, composed of cells becoming laterally compressed, with thin, colorless walls and enlarged lumina. Hamathecium 0.8-1.9 $\mu \mathrm{m}$ composed of paraphyses and periphyses. Paraphyses septate, simple, poorly branched becoming evanescent, branched, hymenial gelatineous. Asci 46-69 $\mu \mathrm{m} \times 8-10 \mu \mathrm{m}(\bar{x}=56.2 \times 9.3 \mu \mathrm{m}, \mathrm{n}=10)$, 8-spored, elongate claviform to cylindrical, shortly stalked, unitunicate, thin-walled, slightly thickened at the apex of young asci. Ascospores 29-39 $\mu \mathrm{m} \times 2.3-2.4 \mu \mathrm{m}(\bar{x}=35.5 \times 2.3 \mu \mathrm{m}, \mathrm{n}=10)$, overlapping in the ascus, simple, cylindrical to filiform, one or more transverse septa, not constricted at the septa, thin-walled without mucilaginous sheath. Asexual morph: Undetermined.

Material examined - USA, California, foothills of the Santa Monica Range near the Soldiers Horne, on the rock, 1 January 1897, A. Zahlbruckner (FH 00213640, holotype).

Economic significance - None is reported.

Bahusakala Subram., J. Indian bot. Soc. 37: 63 (1958)

Pathogenic on leaves in terrestrial habitat. Sexual morph: Undetermined. Asexual morph: Hyphomycetous. Mycelium hairy, dense, partly immersed, partly superficial, congested, effuse, composed of branched, septate, thick-walled, olive-black hyphae. Stroma none. Setae and hyphopodia absent. Conidiophores distinct, solitary, macronematous, mononematous, arthric, erect, branched, cylindrical, smooth to verruculose, septate, thick-walled, producing arthroconidium. Conidiogenous cells holothallic, terminal, integrated, brown, smooth, $8 \mu \mathrm{m}$ long, $3 \mu \mathrm{m}$ wide at the tip. Conidia simple, more or less cylindrical or oblong, brown or dark brown, smooth, wrinkled or verrucose with one or more transverse septa.

Type species - Bahusakala olivaceonigra (Berk. \& Broome) Subram.

Notes - Bahusakala olivaceonigra is the type species of genus Bahusakala, which comprises six species (Index Fungorum 2019). According to Seifert et al. (2011), the genus Bahusakala probably has sexual morphs in Aulographina (Asterinaceae, Dothideomycetes) or Xylogone (Leotiomycetes) but this information warrants further studies. This fungus can be found in areas with a wide range of climatic conditions (Farr \& Rossman 2017) and has been reported to cause leaf blight disease of the sisal (Agave sisalana). In this study, we re-examined the holotype specimen of Bahusakala olivaceonigra. We also did phylogenetic analysis using the putative strains of Bahusakala longispora CBS 544.84. The latter forms a distinct clade in the Sordariomycetes with low bootstrap support (Fig. 68). Species of Bahusakala resemble Parasympodiella in having distinct, single conidiophores with terminal and intercalary, integrated, indeterminate, sympodially extending, conidiogenous cells that produce catenate, cylindrical, thallic conidia by disarticulations of the fertile branches. Parasympodiella is accommodated in its 
own family Parasympodiellaceae, Parasympodiellales (Hernández-Restrepo et al. 2017). We place the genus Bahusakala in Sordariomycetes, genera incertae sedis.

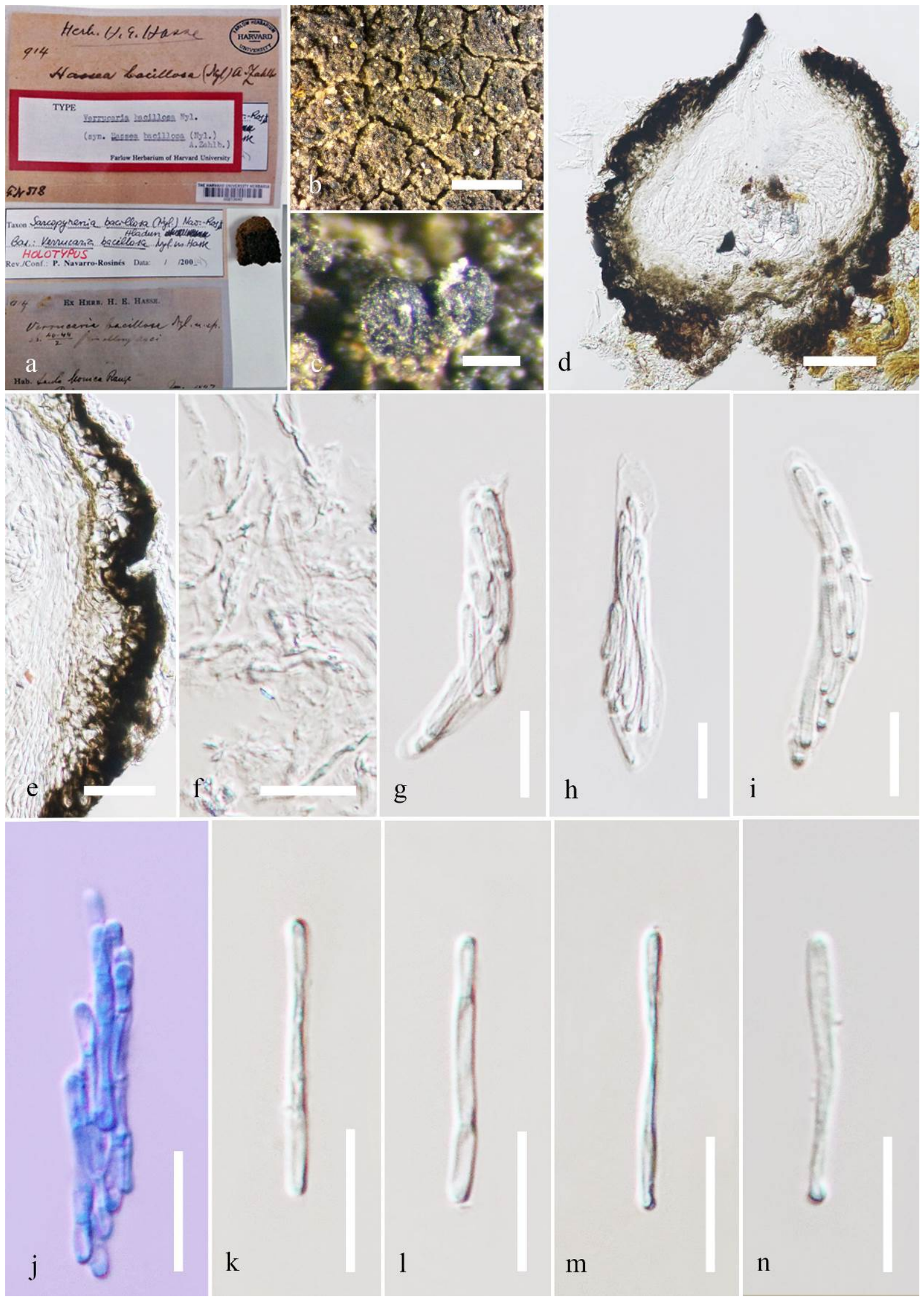

Figure 67 - Hassea bacillosa (FH 00213640, holotype). a Details of herbarium material. b, c Habit and appearance of ascomata on host surface. $d$ Section of ascoma. e Peridium. f Hamathecium. g-i 
Asci. j-n Ascospores. Note: j stained in lactophenol cotton blue. Scale bars: $b=2 \mathrm{~mm}, \mathrm{c}=200 \mu \mathrm{m}$, $\mathrm{d}=100 \mu \mathrm{m}, \mathrm{e}=30 \mu \mathrm{m}, \mathrm{f}=10 \mu \mathrm{m}, \mathrm{g}-\mathrm{n}=20 \mu \mathrm{m}$.

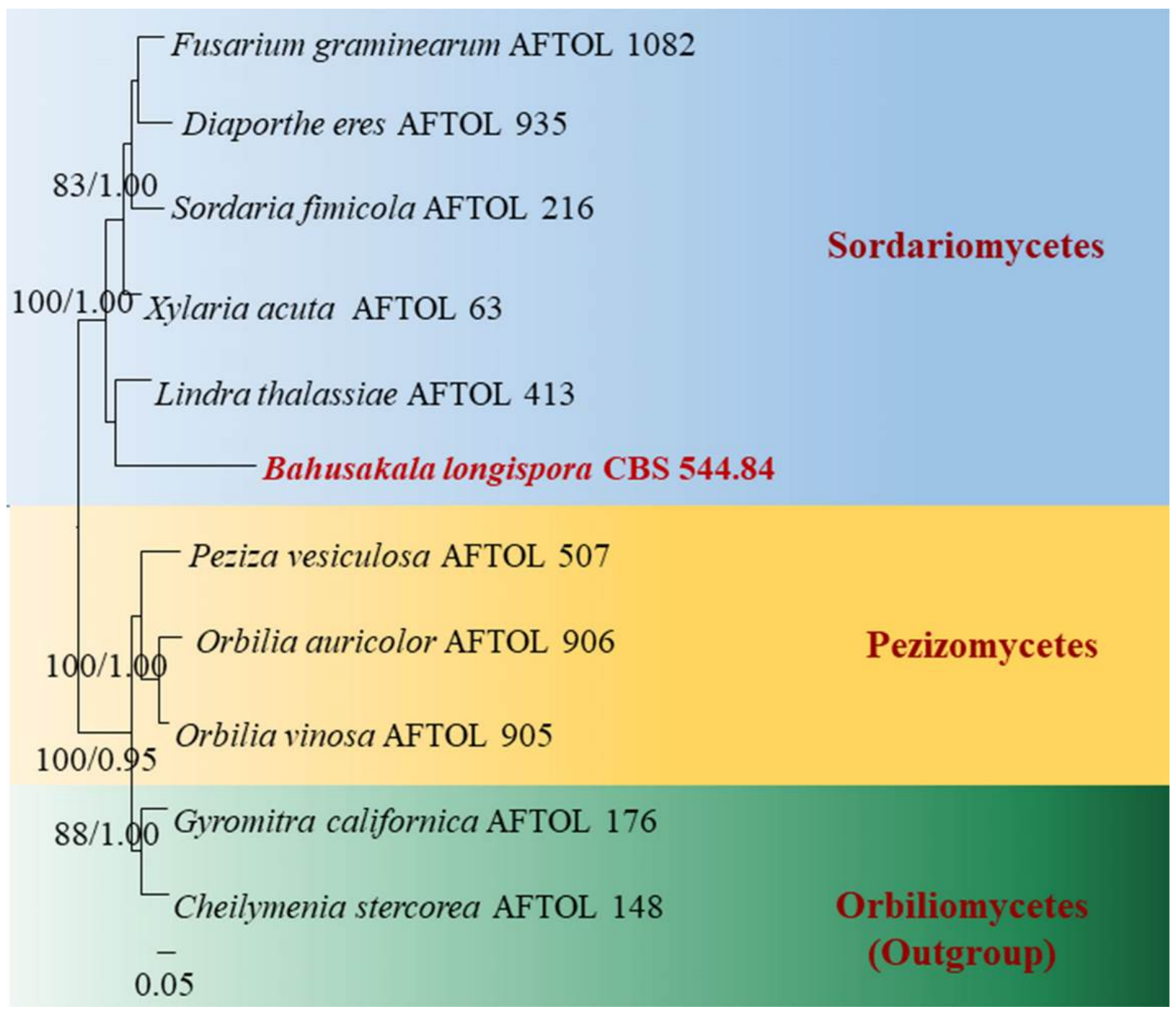

Figure 68 - Phylogram generated from maximum likelihood analysis based on combined LSU, sequence data retrieved from the GenBank. Related sequences were referred to Liu et al. (2017). Eleven taxa are included in the genes sequence analyses which comprise total 923 characters after alignment. Gyromitra californica (AFTOL 176) and Cheilymenia stercorea (AFTOL 148) are used as the out-group taxa. Maximum likelihood (ML) analysis was conducted in the CIPRES Science Gateway V. 3.3. The best sorting RaXML tree with a final likelihood value of -4643.563264 is presented. Estimated base frequencies were as follows: $\mathrm{A}=0.252550, \mathrm{C}=0.217382, \mathrm{G}=$ 0.308330, $\mathrm{T}=0.221738$; substitution rates $\mathrm{AC}=0.405017, \mathrm{AG}=1.017741, \mathrm{AT} 0.509145, \mathrm{CG}=$ $0.483871, \mathrm{CT}=4.087105, \mathrm{GT}=1.000000$; gamma distribution shape parameter $\alpha=0.580334$; proportion of invariant 0.318519 . ML bootstrap values $\geq 50 \%$ are given as the first set of numbers and approximate likelihood-ratio test $(\mathrm{aLRT}) \geq 0.90$ values as the second set of numbers above the nodes. Voucher/strain numbers are given after the taxon names, the one from type material are indicated in bold face. Sequence of interest is indicated in red. The bar length indicates the number of nucleotide substitutions per site.

Bahusakala olivaceonigra (Berk. \& Broome) Subram. [as 'olivaceo-nigra'], J. Indian bot. Soc. 37: 63 (1958) [1875]

$\equiv$ Septonema olivaceonigrum Berk. \& Broome, J. Linn. Soc., Bot. 14(no. 74): 90 (1873) 
Index Fungorum number: IF 293585; Facesoffungi number: FoF 06217
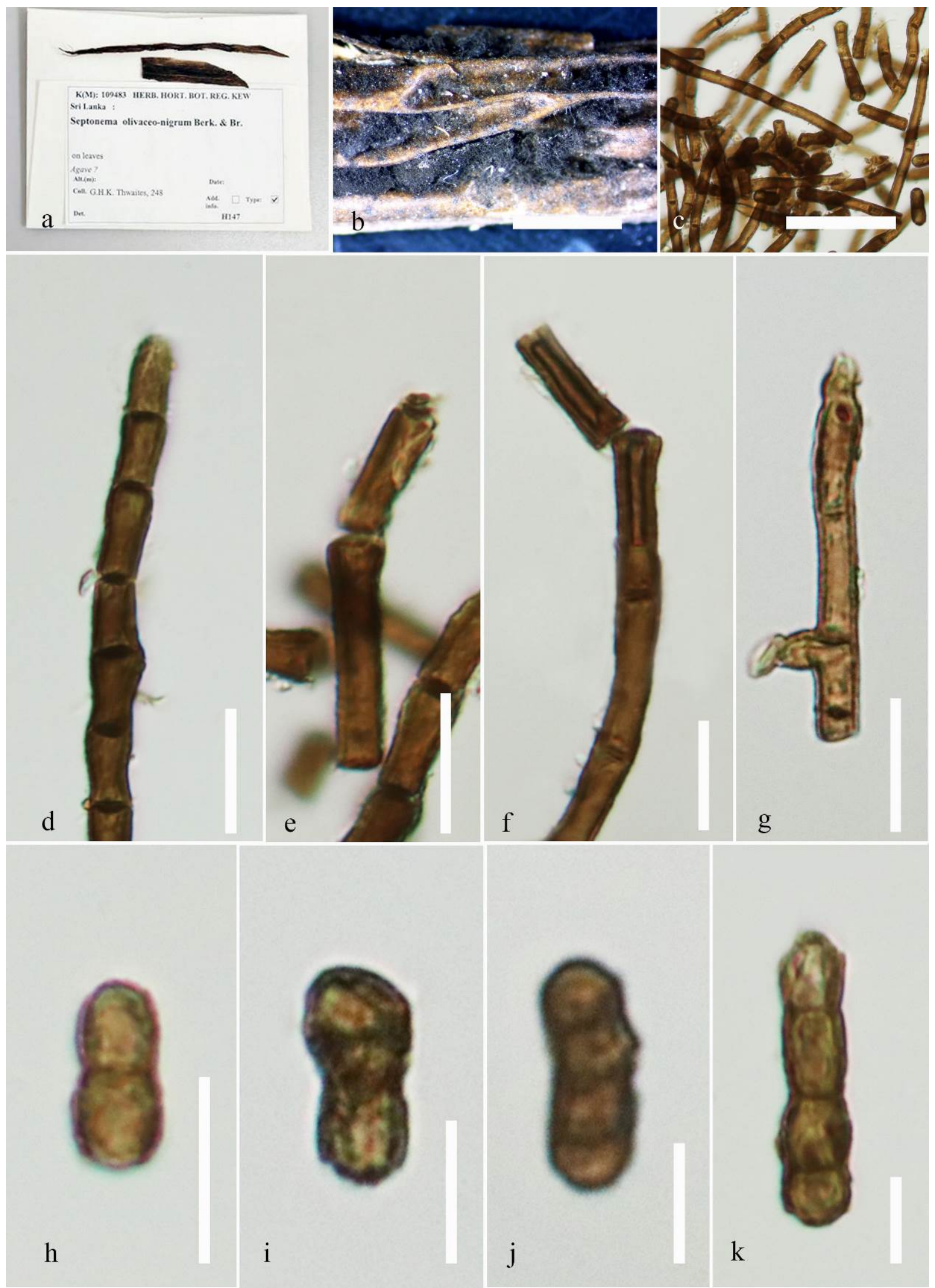

Figure 69 - Bahusakala olivaceonigra (K (M) 109483, holotype). a, b Herbarium specimen and habit on leaf. c Squash mount of conidioma. d-g Conidiophores. h-k Conidia. Scale bars: $b=1$ $\mathrm{mm}, \mathrm{c}=30 \mu \mathrm{m}, \mathrm{d}-\mathrm{g}=10 \mu \mathrm{m}, \mathrm{h}-\mathrm{k}=5 \mu \mathrm{m}$. 


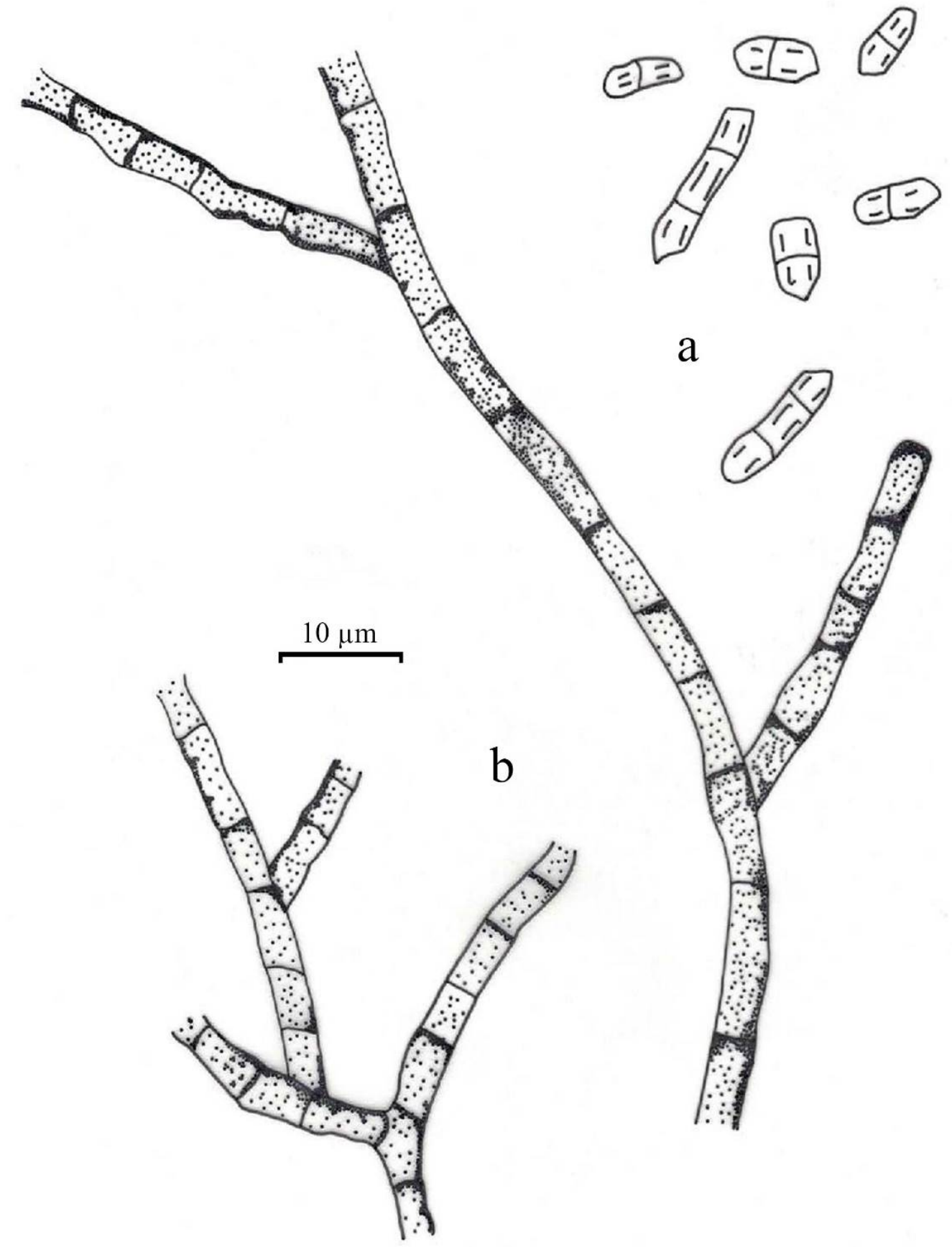

Figure 70 - Bahusaka1a olivaceonigra (redrawn from Guarro et al. 1980). a. Conidia b. Conidiophores. Scalebar: $\mathrm{x}=10 \mu \mathrm{m}$.

Pathogenic on leaves of Agave sisalana in terrestrial habitat. Sexual morph: Undetermined. Asexual morph: Hyphomycetous. Mycelium hairy, dense, partly immersed, partly superficial, congested, effuse, composed of branched, septate, thick-walled, olive-black 2-3.5 $\mu \mathrm{m}$ hyphae. Stroma none. Setae and hyphopodia absent. Conidiophores 28-60 $\mu \mathrm{m} \times 2.5-3.5 \mu \mathrm{m}(\bar{x}=38 \times 3$ $\mu \mathrm{m}, \mathrm{n}=20$ ), distinct, solitary, macronematous, mononematous, arthric, erect, branched, cylindrical, smooth to verruculose, septate, thick-walled, producing arthroconidium. Conidiogenous cells 7-8.5 $\mu \mathrm{m} \times 2-4 \mu \mathrm{m}(\bar{x}=8 \times 3 \mu \mathrm{m}, \mathrm{n}=20)$, holothallic, terminal, integrated, brown, smooth, $8 \mu \mathrm{m}$ long, $3 \mu \mathrm{m}$ wide at the tip. Conidia $6.4-12.3 \mu \mathrm{m} \times 2.8-4.4 \mu \mathrm{m}(\bar{x}=8.1 \times 3.4 \mu \mathrm{m}, \mathrm{n}=10)$, simple, more or less cylindrical or oblong, brown or dark brown, smooth, wrinkled or verrucose with one or more transverse septa.

Material examined - SRI LANKA, on leaves of Agave sisalana (Asparagaceae), 1873, G.H.K Thwaites (K (M) 109483, holotype). 
Economic significance - The genus Bahusakala is the causal organism of leaf blight disease of the sisal (Agave sisalana). The fungus can infect the leaf tissue through wounding (Phuphaibun et al. 1980). It has also been identified as seed-borne mycota from seed samples collected from various localities of Pakistan and other countries (Rahim et al. 2013).

Table 1 The circumscription of different genus in the class Dothideomycetes as it changed during the past decade.

\begin{tabular}{|c|c|c|c|c|c|}
\hline & \multicolumn{5}{|c|}{ Treatment of genus in different publications } \\
\hline Families/ Genera & $\begin{array}{c}\text { Lumbsch \& Hundorf } \\
\text { (2007) }\end{array}$ & $\begin{array}{c}\text { Lumbsch \& Hundorf } \\
\text { (2010) }\end{array}$ & $\begin{array}{c}\text { Wijayawardene et } \\
\text { al. (2014) }\end{array}$ & $\begin{array}{c}\text { Wijayawardene et } \\
\text { al. (2018) }\end{array}$ & This study \\
\hline \multicolumn{6}{|l|}{$\begin{array}{l}\text { Asterinales M.E. Barr ex D. } \\
\text { Hawksw. \& O.E. Erikss. (= } \\
\text { Asterotexales Firmino et al.) }\end{array}$} \\
\hline Asterinaceae Hansf. & $\begin{array}{l}\text { Dothidasteromella } \\
\text { Höhn. }\end{array}$ & $\begin{array}{l}\text { Dothidasteromella } \\
\text { Höhn. }\end{array}$ & & & $\begin{array}{l}\text { Dothidasteromella } \\
\text { Höhn. }\end{array}$ \\
\hline \multicolumn{6}{|l|}{$\begin{array}{l}\text { Botryosphaeriales C.L. Schoch, } \\
\text { Crous \& Shoemaker }\end{array}$} \\
\hline $\begin{array}{l}\text { Botryosphaeriaceae Theiss. \& H. } \\
\text { Syd. }\end{array}$ & & & & & Gibberidea Fuckel \\
\hline \multicolumn{6}{|l|}{ Capnodiales Woron. } \\
\hline Antennulariellaceae Woron. & & & & & Eumela Syd. \\
\hline Mycosphaerellaceae Lindau & & & & $\begin{array}{l}\text { Anguillosporella U. } \\
\text { Braun }\end{array}$ & \\
\hline $\begin{array}{l}\text { Schizothyriaceae Höhn. ex } \\
\text { Trotter et al. }\end{array}$ & $\begin{array}{l}\text { Linopeltis I. Hino \& } \\
\text { Katum. }\end{array}$ & $\begin{array}{l}\text { Linopeltis I. Hino \& } \\
\text { Katum. }\end{array}$ & $\begin{array}{l}\text { Linopeltis I. Hino \& } \\
\text { Katum. }\end{array}$ & & \\
\hline \multicolumn{6}{|l|}{ Dothideales Lindau } \\
\hline \multicolumn{6}{|l|}{ Dothideaceae Chevall. } \\
\hline Dothioraceae Theiss. \& H. Syd. & Botryochora Torrend & Botryochora Torrend & & & \\
\hline $\begin{array}{l}\text { Dothideales, genus incertae } \\
\text { sedis }\end{array}$ & & & & & $\begin{array}{l}\text { Botryochora } \\
\text { Torrend }\end{array}$ \\
\hline \multicolumn{6}{|l|}{ Microthyriales G. Arnaud 1918} \\
\hline Microthyriaceae Sacc. & $\begin{array}{l}\text { Asteronia (Sacc.) P. } \\
\text { Henn. } \\
\text { Asterinema Bat. \& } \\
\text { Gayao }\end{array}$ & $\begin{array}{l}\text { Asteronia (Sacc.) P. } \\
\text { Henn } \\
\text { Asterinema Bat. \& } \\
\text { Gayao }\end{array}$ & & & \\
\hline
\end{tabular}


Table 1 Continued.

\begin{tabular}{|c|c|c|c|c|c|}
\hline Families/ Genera & $\begin{array}{c}\text { Lumbsch \& Hundorf } \\
\text { (2007) }\end{array}$ & $\begin{array}{c}\text { Lumbsch \& Hundorf } \\
\text { (2010) } \\
\end{array}$ & $\begin{array}{c}\text { Wijayawardene et } \\
\text { al. (2014) }\end{array}$ & $\begin{array}{c}\text { Wijayawardene et } \\
\text { al. (2018) }\end{array}$ & This study \\
\hline \multicolumn{6}{|l|}{ Pleosporales Luttr. ex M.E. Barr } \\
\hline $\begin{array}{l}\text { Dothidotthiaceae Crous \& A.J.L. } \\
\text { Phillips }\end{array}$ & & & & & $\begin{array}{l}\text { Belizeana Kohlm. \& } \\
\text { Volkm. }\end{array}$ \\
\hline Lophiostomataceae Sacc. & Byssolophis Clem. & Byssolophis Clem. & & & \\
\hline $\begin{array}{l}\text { Lophiotremataceae K. Hiray. \& } \\
\text { Kaz. Tanaka }\end{array}$ & & & & & Koordersiella Höhn. \\
\hline Massariaceae Nitschke & Dothivalsaria Petr. & Dothivalsaria Petr. & & & \\
\hline Massarinaceae Munk & & & & & $\begin{array}{l}\text { Byssothecium } \\
\text { Fuckel }\end{array}$ \\
\hline Pleomassariaceae M.E. Barr & Asteromassaria Höhn. & Asteromassaria Hohn. & & & \\
\hline Pleosporaceae Nitschke & & & & & $\begin{array}{l}\text { Gibbago E.G. } \\
\text { Simmon }\end{array}$ \\
\hline Teichosporaceae M.E. Barr & Byssothecium Fuckel & Byssothecium Fuckel & & & \\
\hline $\begin{array}{l}\text { Tetraplosphaeriaceae Kaz. } \\
\text { Tanaka \& K. Hiray. }\end{array}$ & & & & & Byssolophis Clem. \\
\hline $\begin{array}{l}\text { Pleosporales genus incertae } \\
\text { sedis }\end{array}$ & & & Macrovalsaria Petr. & $\begin{array}{l}\text { Bactrodesmium } \\
\text { Cooke }\end{array}$ & Homostegia Fuckel \\
\hline \multicolumn{6}{|l|}{$\begin{array}{l}\text { Tubeufiales Boonmee \& K.D. } \\
\text { Hyde }\end{array}$} \\
\hline Tubeufiaceae M.E. Barr & Byssocallis Syd. & Byssocallis Syd. & & & \\
\hline \multicolumn{6}{|l|}{$\begin{array}{l}\text { Venturiales Y. Zhang ter, C.L. } \\
\text { Schoch \& K.D. Hyde }\end{array}$} \\
\hline $\begin{array}{l}\text { Venturiaceae E. Müll. \& Arx ex } \\
\text { M.E. Barr }\end{array}$ & Botryostroma Höhn. & Botryostroma Höhn. & & & \\
\hline \multicolumn{6}{|l|}{$\begin{array}{l}\text { Dothideomycetes, families } \\
\text { incertae sedis }\end{array}$} \\
\hline $\begin{array}{l}\text { Coccoideaceae Henn. ex Sacc. \& } \\
\text { D. Sacc. }\end{array}$ & & & & & $\begin{array}{l}\text { Englerodothis } \\
\text { Theiss. \& Syd. }\end{array}$ \\
\hline $\begin{array}{l}\text { Dubujianaceae D. Pem, Doilom } \\
\text { \& K.D. Hyde, fam. nov. }\end{array}$ & & & & & $\begin{array}{l}\text { Dubujiana D.R. } \\
\text { Reynolds \& G.S. } \\
\text { Gilbert }\end{array}$ \\
\hline
\end{tabular}


Table 1 Continued.

\begin{tabular}{|c|c|c|c|c|c|}
\hline Families/ Genera & $\begin{array}{c}\text { Lumbsch \& Hundorf } \\
(2007)\end{array}$ & $\begin{array}{c}\text { Lumbsch \& Hundorf } \\
(2010)\end{array}$ & $\begin{array}{l}\text { Wijayawardene et } \\
\text { al. (2014) }\end{array}$ & $\begin{array}{l}\text { Wijayawardene et } \\
\text { al. (2018) }\end{array}$ & This study \\
\hline $\begin{array}{l}\text { Endosporiaceae D. Pem, Doilom } \\
\text { \& K.D. Hyde, fam. nov. }\end{array}$ & & & & & $\begin{array}{l}\text { Endosporium } \\
\text { Tsuneda }\end{array}$ \\
\hline $\begin{array}{l}\text { Macrovalsariaceae D. Pem, } \\
\text { Doilom \& K.D Hyde, fam. nov. }\end{array}$ & & & & & Macrovalsaria Petr. \\
\hline Micropeltidaceae Clem. \& Shear & Bonaria Bat. & Bonaria Bat. & & & \\
\hline Naetrocymbaceae Höhn. & & & & & Bonaria Bat. \\
\hline $\begin{array}{l}\text { Parmulariaceae E. Müll. \& Arx } \\
\text { ex }\end{array}$ & $\begin{array}{l}\text { Coccodothis Theiss. \& } \\
\text { Syd. } \\
\text { Englerodothis Theiss. } \\
\text { \& Syd. }\end{array}$ & $\begin{array}{l}\text { Coccodothis Theiss. \& } \\
\text { Syd. } \\
\text { Englerodothis Theiss. \& } \\
\text { Syd. }\end{array}$ & & & \\
\hline $\begin{array}{l}\text { Perisporiopsidaceae E. Müll. \& } \\
\text { Arx }\end{array}$ & & & & & $\begin{array}{l}\text { Asteronia (Sacc.) P. } \\
\text { Henn. } \\
\text { Byssocallis Syd. }\end{array}$ \\
\hline Pseudoperisporiaceae Toro & Eumela Syd. & Eumela Syd. & Eumela Syd. & & \\
\hline Vizellaceae H.J. Swart & & & & & Acarella Syd. \\
\hline $\begin{array}{l}\text { Dothideomycetes, genera } \\
\text { incertae sedis }\end{array}$ & $\begin{array}{l}\text { Gibberidea Fuckel } \\
\text { Homostegia Fuckel } \\
\text { Hypobryon Döbbeler } \\
\text { Belizeana Kohlm. \& } \\
\text { Volkm. } \\
\text { Koordersiella Höhn. } \\
\text { Macrovalsaria Petr. } \\
\text { Didymocyrtidium } \\
\text { Vain. } \\
\text { Achorella Theiss. \& } \\
\text { Syd. } \\
\text { Bryorella Döbbeler } \\
\text { Cerodothis Muthappa } \\
\text { Chionomyces } \\
\text { Deighton \& Piroz. } \\
\text { Chuppia Deighton }\end{array}$ & $\begin{array}{l}\text { Gibberidea Fuckel } \\
\text { Homostegia Fuckel } \\
\text { Hypobryon Dobbeler } \\
\text { Belizeana Kohlm. \& } \\
\text { Volkm. } \\
\text { Koordersiella Hohn. } \\
\text { Macrovalsaria Petr. } \\
\text { Didymocyrtidium Vain. } \\
\text { Achorella Theiss. \& } \\
\text { Syd. } \\
\text { Bryorella Dobbeler } \\
\text { Cerodothis Muthappa } \\
\text { Dermatodothis Racib. } \\
\text { ex Theiss. \& Syd. } \\
\text { Gilletiella Sacc. \& P. } \\
\text { Syd. } \\
\text { Harknessiella Sacc. } \\
\text { Limaciniopsis Mend. }\end{array}$ & $\begin{array}{l}\text { Hypobryon Döbbeler } \\
\text { Dothidasteromella } \\
\text { Höhn. } \\
\text { Botryochora Torrend } \\
\text { Byssolophis Clem. } \\
\text { Dothivalsaria Petr. } \\
\text { Bonaria Bat. } \\
\text { Asteronia (Sacc.) } \\
\text { Henn. } \\
\text { Asterinema Bat. \& } \\
\text { Gayão } \\
\text { Byssothecium Fuckel } \\
\text { Byssocallis Syd. } \\
\text { Coccodothis Theiss. } \\
\text { \& Syd. } \\
\text { Englerodothis } \\
\text { Theiss. \& Syd. }\end{array}$ & $\begin{array}{l}\text { Hypobryon Döbbeler } \\
\text { Dothidasteromella } \\
\text { Höhn. } \\
\text { Botryochora Torrend } \\
\text { Dothivalsaria Petr. } \\
\text { Byssocallis Syd. } \\
\text { Coccodothis Theiss. } \\
\text { \& Syd. } \\
\text { Englerodothis } \\
\text { Theiss. \& Syd. } \\
\text { Asteromassaria } \\
\text { Hohn. } \\
\text { Eumela Syd. } \\
\text { Linopeltis I. Hino \& } \\
\text { Katum. } \\
\text { Gibberidea Fuckel } \\
\text { Homostegia Fuckel }\end{array}$ & $\begin{array}{l}\text { Achorella Theiss. \& } \\
\text { Syd. } \\
\text { Alascospora Raja, } \\
\text { Violi \& Shearer } \\
\text { Anguillosporella U. } \\
\text { Braun } \\
\text { Asterinema Bat. \& } \\
\text { Gayao } \\
\text { Asteromassaria } \\
\text { Höhn. } \\
\text { Asteromella Pass. \& } \\
\text { Thüm. } \\
\text { Bactrodesmium } \\
\text { Cooke } \\
\text { Botryostroma Höhn. } \\
\text { Bryorella Döbbeler } \\
\text { Cerodothis } \\
\text { Muthappa }\end{array}$ \\
\hline
\end{tabular}


Table 1 Continued.

\begin{tabular}{|c|c|c|c|c|c|}
\hline Families/ Genera & $\begin{array}{c}\text { Lumbsch \& Hundorf } \\
\text { (2007) }\end{array}$ & $\begin{array}{c}\text { Lumbsch \& Hundorf } \\
\text { (2010) }\end{array}$ & $\begin{array}{c}\text { Wijayawardene et } \\
\text { al. (2014) }\end{array}$ & $\begin{array}{c}\text { Wijayawardene et } \\
\text { al. (2018) }\end{array}$ & This study \\
\hline & $\begin{array}{l}\text { Dermatodothis Racib. } \\
\text { ex Theiss. \& Syd. } \\
\text { Excipulariopsis P.M. } \\
\text { Kirk \& Spooner } \\
\text { Gilletiella Sacc. \& P. } \\
\text { Syd. } \\
\text { Harknessiella Sacc. } \\
\text { Limaciniopsis J.M. } \\
\text { Mend. } \\
\text { Kullhemia P. Karst. } \\
\text { Bahusutrabeeja } \\
\text { Subram. \& Bhat } \\
\text { Botryohypoxylon } \\
\text { Samuels \& J.D. } \\
\text { Rogers } \\
\text { Dilophospora Desm. } \\
\text { Hassea Zahlbr. }\end{array}$ & $\begin{array}{l}\text { Kullhemia P. Karst. } \\
\text { Bahusutrabeeja } \\
\text { Subram. \& Bhat } \\
\text { Botryohypoxylon } \\
\text { Samuels \& J.D. Rogers }\end{array}$ & $\begin{array}{l}\text { Asteromassaria } \\
\text { Höhn. } \\
\text { Gibberidea Fuckel } \\
\text { Homostegia Fuckel } \\
\text { Belizeana Kohlm. \& } \\
\text { Volkm.-Kohlm. } \\
\text { Koordersiella Höhn. } \\
\text { Dothichiza Lib. ex } \\
\text { Roum. } \\
\text { Dianesea Inácio \& } \\
\text { P.F. Cannon } \\
\text { Didymocyrtidium } \\
\text { Vain } \\
\text { Dubujiana D.R. } \\
\text { Reynolds \& G.S. } \\
\text { Gilbert } \\
\text { Acarella Syd. } \\
\text { Achorella Theiss. \& } \\
\text { Syd. } \\
\text { Alascospora Raja et } \\
\text { al. } \\
\text { Anguillosporella U. } \\
\text { Braun } \\
\text { Asteromella Pass. \& } \\
\text { Thüm. } \\
\text { Bactrodesmium } \\
\text { Cooke } \\
\text { Bahusakala Subram. } \\
\text { Bryorella Döbbeler } \\
\text { Cerodothis } \\
\text { Muthappa } \\
\text { Chaetosticta Petr. \& } \\
\text { Syd. }\end{array}$ & $\begin{array}{l}\text { Belizeana Kohlm. \& } \\
\text { Volkm. } \\
\text { Koordersiella Hohn. } \\
\text { Macrovalsaria Petr. } \\
\text { Dothichiza Lib. ex } \\
\text { Roum. } \\
\text { Dianesea Inacio \& } \\
\text { P.F. Cannon } \\
\text { Didymocyrtidium } \\
\text { Vain } \\
\text { Dubujiana D.R. } \\
\text { Reynolds \& G.S. } \\
\text { Gilbert } \\
\text { Achorella Theiss. \& } \\
\text { Syd. } \\
\text { Asteromella Pass. \& } \\
\text { Thum. } \\
\text { Bryorella Dobbeler } \\
\text { Cerodothis } \\
\text { Muthappa } \\
\text { Chionomyces } \\
\text { Deighton \& Piroz. } \\
\text { Chuppia Deighton } \\
\text { Dermatodothis } \\
\text { Racib. ex Theiss. \& } \\
\text { Syd. } \\
\text { Endosporium } \\
\text { Tsuneda } \\
\text { Excipulariopsis P.M. } \\
\text { Kirk \& Spooner } \\
\text { Gibbago E.G. } \\
\text { Simmons }\end{array}$ & $\begin{array}{l}\text { Chaetosticta Petr. \& } \\
\text { Syd. } \\
\text { Chionomyces } \\
\text { Deighton \& Piroz. } \\
\text { Chuppia Deighton } \\
\text { Coccodothis Theiss. } \\
\text { \& Syd. } \\
\text { Dermatodothis } \\
\text { Racib. ex Theiss. \& } \\
\text { Syd. } \\
\text { Dianesea Inácio \& } \\
\text { P.F. Cannon } \\
\text { Didymocyrtidium } \\
\text { Vain. } \\
\text { Dothichiza Lib. ex } \\
\text { Roum. } \\
\\
\text { Dothivalsaria Petr. } \\
\text { Excipulariopsis } \\
\text { P.M. Kirk \& } \\
\text { Spooner } \\
\text { Gilletiella Sacc. \& } \\
\text { P. Syd. } \\
\text { Harknessiella Sacc. } \\
\text { Hypobryon } \\
\text { Döbbeler } \\
\text { Lignosphaeria } \\
\text { Boonmee, } \\
\text { Thambug. \& K.D. } \\
\text { Hyde } \\
\text { Limaciniopsis J.M. } \\
\text { Mend. }\end{array}$ \\
\hline
\end{tabular}


Table 1 Continued.

\begin{tabular}{|c|c|c|c|c|c|}
\hline Families/ Genera & $\begin{array}{c}\text { Lumbsch \& Hundorf } \\
(2007)\end{array}$ & $\begin{array}{c}\text { Lumbsch \& Hundorf } \\
(2010)\end{array}$ & $\begin{array}{c}\text { Wijayawardene et } \\
\text { al. (2014) }\end{array}$ & $\begin{array}{c}\text { Wijayawardene et } \\
\text { al. (2018) }\end{array}$ & This study \\
\hline & & & $\begin{array}{l}\text { Chionomyces } \\
\text { Deighton \& Piroz. } \\
\text { Chuppia Deighton } \\
\text { Dermatodothis } \\
\text { Racib. ex Theiss. \& } \\
\text { Syd. } \\
\text { Endosporium } \\
\text { Tsuneda } \\
\text { Excipulariopsis P.M. } \\
\text { Kirk \& Spooner } \\
\text { Gibbago E.G. } \\
\text { Simmon } \\
\text { Gilletiella Sacc. \& P. } \\
\text { Syd. } \\
\text { Harknessiella Sacc. } \\
\text { Limaciniopsis J.M. } \\
\text { Mend. } \\
\text { Kullhemia P. Karst. } \\
\text { Bahusutrabeeja } \\
\text { Subram. \& Bhat } \\
\text { Botryohypoxylon } \\
\text { Samuels \& J.D. } \\
\text { Rogers } \\
\text { Dilophospora Desm. } \\
\text { Hassea Zahlbr. }\end{array}$ & $\begin{array}{l}\text { Gilletiella Sacc. \& P. } \\
\text { Harknessiella Sacc. } \\
\text { Lignosphaeria } \\
\text { Boonmee et al. } \\
\text { Limaciniopsis Mend. } \\
\text { Kullhemia P. Karst. } \\
\text { Botryohypoxylon } \\
\text { Samuels \& J.D. } \\
\text { Rogers } \\
\text { Dilophospora Desm. } \\
\text { Hassea Zahlbr. }\end{array}$ & $\begin{array}{l}\text { Linopeltis I. Hino \& } \\
\text { Katum. }\end{array}$ \\
\hline \multicolumn{6}{|l|}{$\begin{array}{l}\text { Ascomycota, families incertae } \\
\text { sedis }\end{array}$} \\
\hline $\begin{array}{l}\text { Strangosporaceae S. Stenroos, } \\
\text { Miądl. \& Lutzoni }\end{array}$ & & & & & Kullhemia P. Karst. \\
\hline $\begin{array}{l}\text { Ascomycota genera incertae } \\
\text { sedis }\end{array}$ & & & & $\begin{array}{l}\text { Acarella Syd. } \\
\text { Botryostroma Hohn. }\end{array}$ & \\
\hline $\begin{array}{l}\text { No mention of the genus in the } \\
\text { outline }\end{array}$ & $\begin{array}{l}\text { Dianesea Inácio \& } \\
\text { P.F. Cannon }\end{array}$ & $\begin{array}{l}\text { Chionomyces Deighton } \\
\text { \& Piroz. }\end{array}$ & $\begin{array}{l}\text { Lignosphaeria } \\
\text { Boonmee, Thambug. }\end{array}$ & $\begin{array}{l}\text { Bahusakala Subram. } \\
\text { Byssolophis Clem. }\end{array}$ & \\
\hline
\end{tabular}


Table 1 Continued.

\begin{tabular}{|c|c|c|c|c|c|}
\hline Families/ Genera & $\begin{array}{c}\text { Lumbsch \& Hundorf } \\
(2007)\end{array}$ & $\begin{array}{c}\text { Lumbsch \& Hundorf } \\
(2010)\end{array}$ & $\begin{array}{l}\text { Wijayawardene et } \\
\text { al. (2014) }\end{array}$ & $\begin{array}{c}\text { Wijayawardene et } \\
\text { al. (2018) }\end{array}$ & This study \\
\hline & $\begin{array}{l}\text { Dothichiza Lib. ex } \\
\text { Roum. } \\
\text { Dubujiana D.R. } \\
\text { Reynolds \& G.S. } \\
\text { Gilbert } \\
\text { Acarella Syd. } \\
\text { Alascospora Raja, } \\
\text { Violi \& Shearer (was } \\
\text { not yet published) } \\
\text { Anguillosporella U. } \\
\text { Braun } \\
\text { Asteromella Pass. \& } \\
\text { Thüm. } \\
\text { Bactrodesmium Cooke } \\
\text { Bahusakala Subram. } \\
\text { Chaetosticta Petr. \& } \\
\text { Syd. } \\
\text { Endosporium Tsuneda } \\
\text { (was not yet } \\
\text { published) } \\
\text { Gibbago E.G. } \\
\text { Simmons } \\
\text { Lignosphaeria } \\
\text { Boonmee, Thambug. } \\
\text { \& K.D. Hyde (was not } \\
\text { yet published) }\end{array}$ & $\begin{array}{l}\text { Chuppia Deighton } \\
\text { Dianesea Inácio \& P.F. } \\
\text { Cannon } \\
\text { Dothichiza Lib. ex } \\
\text { Roum. } \\
\text { Dubujiana D.R. } \\
\text { Reynolds \& G.S. } \\
\text { Gilbert } \\
\text { Acarella Syd. } \\
\text { Alascospora Raja, Violi } \\
\text { \& Shearer } \\
\text { Anguillosporella U. } \\
\text { Braun } \\
\text { Asteromella Pass. \& } \\
\text { Thüm. } \\
\text { Bactrodesmium Cooke } \\
\text { Bahusakala Subram. } \\
\text { Chaetosticta Petr. \& } \\
\text { Syd. } \\
\text { Endosporium Tsuneda } \\
\text { Excipulariopsis P.M. } \\
\text { Kirk \& Spooner } \\
\text { Gibbago E.G. Simmons } \\
\text { Lignosphaeria } \\
\text { Boonmee, Thambug. \& } \\
\text { K.D. Hyde (was not yet } \\
\text { published) } \\
\text { Dilophospora Desm. } \\
\text { Hassea Zahlbr. }\end{array}$ & $\begin{array}{l}\text { \& K.D. Hyde (was } \\
\text { not yet published) }\end{array}$ & $\begin{array}{l}\text { Bonaria Bat. } \\
\text { Asteronia (Sacc.) P. } \\
\text { Henn. } \\
\text { Asterinema Bat. \& } \\
\text { Gayao } \\
\text { Byssothecium Fuckel } \\
\text { Alascospora Raja, } \\
\text { Violi \& Shearer } \\
\text { Bahusutrabeeja } \\
\text { Subram. \& Bhat } \\
\text { Chaetosticta Petr. \& } \\
\text { Syd. }\end{array}$ & \\
\hline \multicolumn{6}{|l|}{$\begin{array}{l}\text { Sordariomycetes O.E. Erikss. \& } \\
\text { Winka }\end{array}$} \\
\hline $\begin{array}{l}\text { Chaetothyriales, family incertae } \\
\text { sedis }\end{array}$ & & & & & $\begin{array}{l}\text { Bahusutrabeeja } \\
\text { Subram. \& Bhat }\end{array}$ \\
\hline
\end{tabular}


Table 1 Continued.

\begin{tabular}{|c|c|c|c|c|c|}
\hline Families/ Genera & $\begin{array}{c}\text { Lumbsch \& Hundorf } \\
(2007)\end{array}$ & $\begin{array}{c}\text { Lumbsch \& Hundorf } \\
\text { (2010) }\end{array}$ & $\begin{array}{c}\text { Wijayawardene et } \\
\text { al. (2014) }\end{array}$ & $\begin{array}{c}\text { Wijayawardene et } \\
\text { al. (2018) }\end{array}$ & This study \\
\hline Xylariales, genera incertae sedis & & & & & $\begin{array}{l}\text { Botryohypoxylon } \\
\text { Samuels \& J.D. } \\
\text { Rogers }\end{array}$ \\
\hline Sporocadaceae Corda 1842 & & & & & Dilophospora Desm. \\
\hline $\begin{array}{l}\text { Sordariomycetes genera } \\
\text { incertae sedis }\end{array}$ & & & & & $\begin{array}{l}\text { Hassea Zahlbr. } \\
\text { Bahusakala Subram. }\end{array}$ \\
\hline
\end{tabular}

\section{Acknowledgements}

Dhandevi Pem thanks Mae Fah Luang University for supporting studies in Dothideomycetes. Dhandevi Pem is also thankful to the curators of various herbaria cited in the literature for providing herbarium materials and wishes to extend her sincere appreciation to Chinthani Indunil Senanayake, Kasun Thambugala and Rungtiwa Phookamsak for their great help and contributions in this study. Dr. Alan J.L. Phillips and Dr Damien Ertz are acknowledged for their valuable advice and guidance during this study. Rajesh Jeewon thanks University of Mauritius for research support. Mingkwan Doilom thanks the 5th batch of Postdoctoral Orientation Training Personnel in Yunnan Province (grant no.: Y934283261) and the 64th batch of China Post-doctoral Science Foundation (grant no.: Y913082271). Sinang Hongsanan would like to thank National Natural Science Foundation of China for supporting the project Biodiversity, Taxonomy, Phylogeny, Evolution and Phylogeography of phytopathogens in Dothideomycetes from Southern China (Project number: 31950410548). Saranyaphat Boonmee would like to thank the Thailand Research Fund (No. TRG6180001) and Plant Genetic Conservation Project under the Royal Initiation of Her Royal Highness Princess Maha Chakri Sirindhorn-Mae Fah Luang University. Kevin D. Hyde thanks the Thailand Research Fund for the grant entitled Impact of climate change on fungal diversity and biogeography in the Greater Mekong Subregion (No. RDG6130001) and the Thailand Research Fund entitled "The future of specialist fungi in a changing climate: baseline data for generalist and specialist fungi associated with ants, Rhododendron species and Dracaena species" (No. DBG6080013). This research work is funded by the National Natural Science Foundation of China (31861143002) and is partially supported by Chiang Mai University.

\section{References}

Akhtar K, Sawar N, Saleem K, Ali S. 2013 - Gibbago trianthemae causes Trianthema portulacastrum (horse purslane) blight in Pakistan. Australasian Plant Disease Notes 8 (1), 109-110.

Aneja KR, Kumar V, Sharma C. 2014 - Leaf-spot disease of Trianthema portulacastrum - a new record from world. Journal of Innovative Biology 1 (2), 112-116.

Ariyawansa HA, Thambugala KM, Manamgoda DS, Jayawardena R et al. 2015b - Towards a natural classification and backbone tree for Pleosporaceae. Fungal Diversity 71, 85-139. 
Ariyawansa HA, Camporesi E, Thambugala KM, Mapook A et al. 2014a - Confusion surrounding Didymosphaeria - phylogenetic and morphological evidence suggest Didymosphaeriaceae is not a distinct family. Phytotaxa 176, 102-119.

Ariyawansa HA, Hawksworth DL, Hyde KD, Jones EBG et al. 2014b - Epitypification and neotypification: guidelines with appropriate and inappropriate examples. Fungal Diversity 69, 57-91.

Ariyawansa HA, Jones EBG, Suetrong S, Alias AS et al. 2013a - Halojulellaceae a new family of the order Pleosporales. Phytotaxa 130, 14-24.

Ariyawansa HA, Kang JC, Alias SA, Chukeatirote E et al. 2013b - Towards a natural classification of Dothideomycetes: The genera Dermatodothella, Dothideopsella, Grandigallia, Hysteropeltella and Gloeodiscus (Dothideomycetes incertae sedis). Phytotaxa 147, 35-47.

Ariyawansa HA, Phukhamsakda C, Thambugala KM, Bulgakov TS et al. 2015a - Revision and phylogeny of Leptosphaeriaceae. Fungal Diversity 74, 19-51.

Asad S, Sultan A, Iftikhar S, Munir A et al. 2007- First report of Dilophospora leaf spot (twist) disease of wheat in Pakistan. Pakistan Journal of Botany 39 (4), 1387-1389.

Bagdžiūnaitè A. 2006 - Fungal Diseases on Betula pendula Roth. in Lithuania. IUFRO Working Party 7.03.10 Proceedings of the Workshop 2006, Gmunden/ Austria.

Barbetti MJ, Riley IT. 2006 - Field application of Dilophospora alopecuri to manage annual ryegrass toxicity caused by Rathayibacter toxicus. Plant Disease 90, 229-232.

Barnett HC, Hunter BB. 1972 - Illustrated genera of imperfect fungi. 3rd Edition, Burgress Publishing Co., Minneapolis 20 p.

Barr ME. 1976 - Hypoxylon grandineum: a Loculoascomycete. Mycotaxon 3 (3), 325-329.

Barr ME. 1979a - A classification of Loculoascomycetes. Mycologia 71, 935-957.

Barr ME. 1979b - On the Massariaceae in North America. Mycotaxon 9, 17-37.

Barr ME. 1987- New taxa and combinations in the Loculoascomycetes. Mycotaxon 29, 501-505.

Barr ME. 1990 - Prodromus to nonlichenized, pyrenomycetous members of class Hymenoascomycetes. Mycotaxon 39, 43-184.

Barr ME. 1993 - Notes on the Pleomassariaceae. Mycotaxon 49, 129-142.

Batista AC, Ciferri R. 1963 - Capnodiales. Saccardoa 2, 1-296.

Batista AC, Gayão TJ. 1953 - Vas e curiosas especies de Asterinaceae. Anais do IV Congresso Nacional da Sociedade Botânica do Brasil, 160-176.

Batista AC, Maia HS, Farr ML. 1958 - Novos generos e novas especies de fungos Asterinaceae. Revista de Biologia Lisbõa 1(3-4), 287-298.

Batista AC, Vital AF. 1957 - Recentes estudos sôbre antigos ou novos Ascomycetos. Anais da Sociedade de Biologia de Pernambuco 15 (2), 489-505.

Bayman P, Otero JT. 2006 - Microbial endophytes of orchid roots. In Schulz BJE, Boyle C, Sieber TN [eds.], Microbial root endophytes, 153-178. Springer, New York, New York, USA.

Bedlan G. 2014 - First report of Asteromella pruni-mahaleb comb. nov. (Syn. phyllosticta prunimahaleb pass.) on Prunus armeniaca. Journal fur Kulturpflanzen 66 (3), 90-94.

Berbee ML. 1996 - Loculoascomycete origins and evolution of filamentous ascomycete morphology based on 18s rRNA gene sequence data. Molecular Biology and Evolution 13 (3), 462-470.

Bernier J, Carisse O, Paulitz TC. 1996 - Fungal communities isolated from dead apple leaves from orchards in Quebec. Phytoprotection, 77 (3), 129-134.

Bird AF, McKay AC. 1987 - Adhesion of conidia of the fungus Dilophosphora alopecuri to the cuticle of the nematode Anguina agrostes, the vector in annual ryegrass toxicity. International Journal for Parasitology 17, 1239-1247.

Boise J. 1983 - On Trematosphaeria circinans and Reinstatement of the Genus Byssothecium. Mycologia 75 (4), 666-669. 
Boonmee S, Phookamsak R, Hongsanan S, Doilom M et al. 2017 - Mycosphere notes 51-101. Revision of genera in Perisporiopsidaceae and Pseudoperisporiaceae and other Ascomycota genera incertae sedis. Mycosphere 8, 1695-1801.

Boonmee S, Rossmana AY, Liu JK, Li WJ. 2014 - Tubeufiales, ord. nov., integrating sexual and asexual generic names. Fungal Diversity 68, 239-298.

Boonmee S, Zhang Y, Chomnunti P, Chukeatirote E. 2011 - Revision of lignicolous Tubeufiaceae based on morphological re-examination and phylogenetic analysis. Fungal Diversity 51, 63102.

Braun U. 2013 - A monograph of Cercosporella, Ramularia and allied genera (phytopathogenic hyphomycetes). Additions to host range and distribution. Schlechtendalia 1, 41-43.

Bronson CH. 2018 - Annual report of the Department of Agriculture and Consumer Services for the year 2006-2007. Available at:

Butin H, Kehr R. 1995 - Leaf blotch of lime associated with Asteromella tiliae comb. nov. and the latter's connection to Didymosphaeria petrakiana. Mycological research 99 (10), 1191-1194.

Butin H, Kehr R. 2004 - Sphaceloma murrayae Jenk. and Grods., a pathogen new to Europe on Salix spp. Forest Pathology 34, 27-31.

Cain RF, Luck-Allen ER. 1969 - Semidelitschia, a new genus of the Sporormiaceae. Mycologia 61, 580-585.

Carmichael JW, Kendrick WB, Conners IL, Sigler L. 1980 - The Genera of Hyphomycetes. University of Alberta Press, Edmonton, AB, pp 386.

Chacón S, Tapia F, Esqueda M. 2014 - New records of Dothideomycetes from Mexico. Mycotaxon 128, 145-157.

Chen MM. 2003 - Forest fungi phytogeography: Forest fungi phytogeography of China, North America, and Siberia and international quarantine of tree pathogens. Pacific Mushroom Research and Education Center Sacramento USA. Available at: https://escholarship.org/content/qt0g42933t/qt0g42933t.pdf (Accessed 18 May 2019).

Chethana T, Liu M, Ariyawansa HA, Konta S, Wanasinghe DN, Zhou Y et al. 2015 Splanchnonema-like species in Pleosporales: introducing Pseudosplanchnonema gen. nov. in Massarinaceae. Phytotaxa 231(2), 133-144.

Chomnunti P, Hongsanan S, Hudson BA, Tian Q et al. 2014 - The sooty moulds. Fungal Diversity 66, 1-36.

Clements FE, Shear CL. 1931 - The genera of Fungi. H.W. Wilson Co., New York pp 1-496.

Cooke MC, Harkness WH. 1884 - Californian fungi. Grevillea 12 (64), 92-97.

Cooke MC. 1883 - Saccardo’s Sylloge Fungorum. Grevillea 12, 34-35.

Crane JL. 1971 - Illinois Fungi II. A new species of Phialocephala. Transactions of the British Mycological Society 56, 160-163.

Crous PW, Schroers HJ, Groenewald JZ, Braun U, Schubert K. 2006 - Metulocladosporiella gen. nov. for the causal organism of Cladosporium speckle disease of banana. Mycological Research, 110, 264-275.

Dasari 2012 - The Biology, Development, and Host Distribution of Epifoliar Fungi in the Mangrove Ferns (Acrostichum aureum) of Mo'orea, French Polynesia. Available at: https://escholarship.org/uc/item/6tq3k5dh

De Gruyter J, Woudenberg JHC, Aveskamp AA, Verkley GJM et al. 2012 - Redisposition of phoma-like anamorphs in Pleosporales. Studies in Mycology 75, 1-36.

Deighton FC, Pirozynski KA. 1972 - Microfungi V. More hyperparasitic hyphomycetes. Mycological Papers 128, 1-110.

Desmazières JBHJ. 1840 - Notice sur quelques plantes cryptogames nouvelles découvertes en France, qui vont paraître en nature dans la collection publiée par l'auteur. Annales des Sciences Naturelles Botanique 13, 181-190.

Döbbeler P, Vézda A. 1982 - Macentina Hepaticola, Eine Neue FlecHTE Aus Zaire - Mitteilungen der Botanischen Staatssammlung München 18, 1-8. 
Döbbeler P. 1978 - Moosbewohnende Ascomyceten I. Die pyrenocarpen, den Gametophyten besiedelnden Arten. - Mitt. Bot. Staatssamml. München 14, 1-360.

Döbbeler P. 1981- Moosbewohnende Ascomyceten. V. Die auf Dawsonia vorkommenden Arten der Botanischen Staatssammlung München. Mitteilungen aus der Botanischen Staatssammlung München 17, 393-473.

Döbbeler P. 1983 - Hypobryon gen. nov. (Dothideales), eine bemerkenswerte Gattung bryophiler Pyrenomyceten. Nova Hedwigia 37, 1-17.

Döbbeler P. 1997 - Biodiversity of bryophilous ascomycetes. Biodiversity and Conservation 6, 721-38.

Doidge EM, Bottomley AM. 2016 - A revised list of plant diseases occurring in South Africa. Dept. of Agriculture. Botany and plant pathology series; no. 16. Science bulletin, no. 346

Doilom M, Hyde KD, Phookamsak R et al. 2018 - Mycosphere Notes 225-274: types and other specimens of some genera of Ascomycota. Mycosphere 9, 647-754.

Doilom M, Manawasinghe IS, Jeewon R, Jayawardena RS, Tibpromma S et al. 2017 - Can ITS sequence data identify fungal endophytes from cultures? A case study from Rhizophora apiculata. Mycosphere 8, 1869-1892.

Dubey R, Pandey AD. 2019 - Statistical analysis of foliicolous fungal biodiversity of Konkan region, Maharashtra, India: A novel approach. Plant Pathology \& Quarantine 9 (1), 77-115.

Ellis MB. 1971 - Dematiaceous hyphomycetes. Mycological Papers 125, 1-30.

Ellis MB. 1976 - More Dematiaceous Hyphomycetes, CAB International Mycological Institute, Kew, England, UK, pp. 1- 507.

Eriksson OE. 1981 - The families of bitunicate Ascomycetes. Opera Botanica 60, 1-209.

Farr DF, Rossman AY. 2017 - Fungal databases, systematic mycology and microbiology laboratory, ARS, USDA. Available from: http://nt.ers-grin.gov/fungaldatabases

Farr ML. 1983 - The genus Asterinema (Ascomycetes, Microthyriaceae). Mycologia 75, 10361043.

Farr ML. 1984 - The Didymosporous Dimeriaceous fungi reported on leaves of Rubiaceae. Mycologia 76 (5), 793-803.

Fries EM. 1828 - Elenchus Fungorum, sistens Commentarium in Systema Mycologicum. Greifswald, Sumptibus Ernesti Mauritii 1, i, 1-238.

Fuckel L. 1861- Mykologisches. Botanische Zeitung 19 (35), 249-252.

Fuckel L. 1870 - Symbolae mycologicae. Beiträge zur Kenntniss der Rheinischen Pilze. Jahrbücher des Nassauischen Vereins für Naturkunde 23-24, 1-459.

Gandipilli G, Ratna Kumar PK. 2018 - Factors influencing growth and sporulation of Gibbago trianthemae, a prospective biocontrol agent. Indian journal of experimental biology 56(11), 847- 852.

Ganie AA. 2010 - Studies on Foliicolous Fungi Associated with Some Plants. (Masters thesis). Aligarh Muslim University. Available at: http://ir.amu.ac.in/7526/ (Accessed 19 January 2019).

Grove WB. 1935 - British Stem and Leaf-Fungi (Coelomycetes). UK, Cambridge, Cambridge University Press 1: i-xx, 1-488.

Hall TA. 1999 - BioEdit: a user-friendly biological sequence alignment editor and analysis program for Windows 95/98/NT. Nucleic Acids Symposium Series 41, 95-98.

Hawksworth DL, Kirk PM, Sutton BC, Pegler DM. 1995 - Ainsworth \& Bisby's dictionary of the fungi. 8th edition. CAB International, Wallingford.

Hawksworth DL. 2016 -A synopsis of the tropical pleomorphic lichenicolous genus Koordersiella (syn. Hansfordiellopsis) under a unified nomenclature. Journal of Yeast and Fungal Research 13, 227-232.

Hedgcock GG, Hunt NR. 1916 - Dothichiza populea in the United States. Mycologia 8(6), 300308.

Hennings P. 1908 - Fungi S. Paulensis IV a cl. Puttemans collecti. Hedwigia 48, 1-20. 
Hernández-Restrepo M, Gené J, Castañeda-Ruiz RF, Mena-Portales et al. 2017 - Phylogeny of saprobic microfungi from Southern Europe. Studies in Mycology, 86, 53-97.

Hernández-Restrepo M, Mena-Portales J, Gené J, Cano J, Guaarro J. 2013 - New Bactrodesmiastrum and Bactrodesmium from decaying wood in Spain. Mycologia 105(1), 172-80.

Hino I, Katumoto K. 1961 - Icones fungorum bambusicolorum Japonicorum. Fungi Bamboo Garden, Gotenba.

Hofmann TA. 2010 - Plant parasitic Asterinaceae and Microthyriaceae from the Neotropics (Panama). PhD Thesis. Frankfurt am Main, Johann Wolfgang Goethe University, p 408.

Höhnel FV. 1909 - Fragmente zur Mykologie: IX. Mitteilung (Nr. 407 bis 467). Sitzungsberichte der Kaiserlichen Akademie der Wissenschaften Math.-naturw. Klasse Abt. I. 118, 1-92.

Höhnel FV. 1910 - Fragmente zur Mykologie: XI. Mitteilung (Nr. 527 bis 573). Sitzungsberichte der Kaiserlichen Akademie der Wissenschaften Math.-naturw. Klasse Abt. I. 119, 617-679.

Höhnel FV. 1911- Fragmente zur Mykologie. XIII Mitteilung (Nr. 642 bis 718). Sitzungsberichte der Kaiserlichen Akademie der Wissenschaften Math.-naturw. Klasse Abt. I. 120, 379-484.

Höhnel FV. 1917 - Mykologische Fragmente. Nrn. 120-190. Annales Mycologici. 15(5), 293-383. Holm L. 1986 - A note on Byssolophis ampla, In: Windahlia 16, 49-52.

Holubová-Jechová V, Hennebert GL. 1972 - Sporoschismopsis, a new genus of lignicolous Hyphomycetes. Bulletin du Jardin Botanique National de Belgique. 42, 385-391.

Hongsanan S, Li YM, Liu JK, Hofmann T et al. 2014 - Revision of genera in Asterinales. Fungal Diversity 68, 1-68.

Hosagoudar VB, Abraham TK, Biju CK. 2001 - Re-evaluation of the family Asterinaceae. Journal of Mycopathological Research 39, 61-63.

Hsieh WH, Chen CY. 1993 - Two new species and one new record of Dermatodothis from Taiwan. Botanical Bulletin of the Academia Sinica (Taipei) 34(3), 271-276.

http://agris.fao.org/agris-search/search.do?recordID=XB8120932

http://evolve.zoo.ox.ac.uk/software.html?id=tracer. (Accessed 31 March 2019).

https://archive.org/stream/AnnualReportOfTheDepartmentOfAgricultureAndConsumerServic esForThe_107/v2006-2007_djvu.txt (Accessed 13 October 2019)

https://nsuworks.nova.edu/occ_stuetd/211 (Accessed 17 May 2019).

Hughes SJ. 1958 - Revisiones Hyphomycetum aliquot cum appendice de nominibus rejiciendis. Canadian Journal of Botany 36(6), 727-836.

Hyde KD, Chaiwan N, Norphanphoun C, Boonmee S et al. 2018 - Mycosphere notes 169-224. Mycosphere 9, 271-430.

Hyde KD, Jones EBG, Liu JK, Ariyawansa H et al. 2013 - Families of Dothideomycetes. Fungal Diversity 63, 1-313.

Hyde KD, McKenzie EHC, Koko TW. 2011 - Towards incorporating anamorphic fungi in a natural classification - checklist and notes for 2010. Mycosphere 2, 1-88.

Hyde KD, Taylor JE, Fröhlich J. 2000 - Genera of Ascomycetes from Palms. Fungal Diversity Research Series 3, 1-247.

Hyde KD, Tennakoon DS, Jeewon R, Bhat DJ, Maharachchikumbura SSN. 2019 - Fungal diversity notes 1036-1150: taxonomic and phylogenetic contributions on genera and species of fungal taxa. Fungal Diversity 96, 1-242.

Inácio CA, Cannon PF. 2002 - Re-interpretation of Cocconia palmae, with description of the genus Dianesea (Ascomycota: Dothideomycetidae). Fungal Diversity 9, 71-79.

Inácio CA, Cannon PF. 2008 - The genera of the Parmulariaceae. CBS Fungal Biodiversity Series, $8,1-195$.

Inácio CA, Minter DW. 2000 - Englerodothis kilimandscharica. [Descriptions of Fungi and Bacteria]. Available at: https://www.cabdirect.org/cabdirect/abstract/20056401449 (Accessed 17 May 2019)

Index Fungorum. 2019 - http://www.indexfungorum.org/Names/Names.asp (Accessed 17 May 2019). 
Janick J, Paull RE. 2008 - The Encyclopedia of Fruits \& Nuts. Wallingford, UK, Cambridge, MA: CABI North American Office.

Jayasiri SC, Ariyawansa HA, Jones EBG, Kang JC. 2016 - Towards a natural classification of Dothideomycetes: 8. The genera Cocconia, Dianesea, Endococcus and Lineostroma. Phytotaxa 255, 66-74.

Jayasiri SC, Hyde KD, Ariyawansa HA, Bhat DJ et al. 2015 - The faces of fungi database: fungal names linked with morphology, phylogeny and human impacts. Fungal Diversity 74, 3-18.

Jayasiri SC, Hyde KD, Jones EBG, McKenzie EHC, Jeewon R, Phillips AJL, Bhat DJ, Wanasinghe DN, Liu JK, Lu YZ, Kang JC, Xu J, Karunarathna SC. 2019 - Diversity, morphology and molecular phylogeny of Dothideomycetes on decaying wild seed pods and fruits. Mycosphere 10 (1), 1-186.

Jones EBG, Suetrong S, Sakayaroj J, Bahkali AH et al. 2015 - Classification of marine Ascomycota, Basidiomycota, Blastocladiomycota and Chytridiomycota. Fungal Diversity 73, $1-72$.

Jones EBG. 2000 - Marine fungi: some factors influencing biodiversity. Fungal Diversity 4: 53-73.

Katoh K, Toh H. 2008 - Recent developments in the MAFFT multiple sequence alignment program. Briefings in Bioinformatics 9, 286-298.

Kirk P, Cannon PF, Minter DW, Stalpers JA. 2008 - Ainsworth \& Bisby’s Dictionary of the Fungi, 10th edn. CAB International, Wallingford.

Kirk PM, Cannon PF, David JC, Stalpers JA. 2001- Ainsworth \& Bisby's Dictionary of the Fungi, 9th Edition. CABI Publishing.

Kirk PM, Stalpers JA, Braun U, Crous PW et al. 2013 - A without prejudice list of generic names of fungi for protection under the International Code of Nomenclature for algae, fungi, and plants. IMA Fungus 4, 381- 443.

Kodsueb R, Jeewon R, Vijaykrishna D, Hyde KD, McKenzie EHC, Lumyong S. 2006 - Systematic revision of Tubeufiaceae based on morphological and molecular data. Fungal Diversity 21, 104-129.

Kodsueb R, Vijaykrishna D, Aptroot A, Lumyong S, McKenzie EHC, Hyde KD, Jeewon R. 2006 The family Pleosporaceae: intergeneric relationships and phylogenetic perspectives based on sequence analyses of partial 28S rDNA. Mycologia 98, 571-583.

Kohlmeyer J, Volkmann-Kohlmeyer B. 1987- Marine fungi from Belize with a description of two new genera of ascomycetes. Botanica Marina 30, 195-204.

Koike S, Gladders P, Paulus A. 2007 - Vegetable diseases: a color handbook. (Manson Publishing Limited: London).

Laemmlen FF. 2011 - Sooty mold. Integrated pest management for home gardeners and landscape professionals. Pest notes, University of California. Agriculture and Natural Resources, USA. Available at: http://www.ipm.ucdavis.edu/PDF/ PESTNOTES/pnsootymold.pdf (Accessed at 17 May 2019).

Lefebvre CL, Stevenson JA. 1945 - The Fungus Causing Zonate Leafspot of Cowpea. Mycologia 37, 37-45.

Li DW, Zhao G, Yang C, Jalsrai A, Kerin B. 2013 - Four noteworthy hyphomycetes from indoor environments. Mycotaxon 125, 111-121.

Li WJ, Bhat JD, Hyde KD, Yong W. 2014 - Towards a natural classification of Dothideomycetes 4: The genera Bryopelta, Bryorella, Bryosphaeria, Lophiosphaerella and Maireella (Dothideomycetes incertae sedis). Phytotaxa, 176, 28-41.

Li WY, Zhuang WY. 2009 - Preliminary study on relationships of Dothideales and its allies. Mycosystema 28, 161-170.

Liew ECY, Aptroot A, Hyde, KD. 2000 - Phylogenetic significance of the pseudoparaphyses in Loculoascomycete taxonomy. Molecular Phylogeny and Evolution 16, 392-402

Liu JK, Hyde KD, Jeewon R, Phillips AJL, Maharachchikumbura SSN et al. 2017 - Ranking higher taxa using divergence times: a case study in Dothideomycetes. Fungal Diversity 84, 75-99. 
Liu JK, Phookamsak R, Doilom M, Wikee S, Li YM, et al. 2012 - Towards a natural classification of Botryosphaeriales. Fungal Diversity 57, 149-210.

Lücking R, Hodkinson BP, Leavitt SD. 2016 - The 2016 classification of lichenized fungi in the Ascomycota and Basidiomycota - Approaching one thousand genera. The Bryologist 119, 361- 416.

Lumbsch HT, Huhndorf SM. 2010 - Outline of Ascomycota 2009. Myconet 14, 1-64.

Lumbsch HT, Lindemuth R, Schmitt I. 2000 - Evolution of filamentous ascomycetes inferred from LSU rDNA sequence data. Plant Biology 2, 525-529.

Marmolejo JG, Butin H. 1997 - Forest fungi from Nuevo León. A new variety of Coccodothis sphaeroidea from Mexico. Mycological Research 101 (12), 1515-1516.

Matsushima T. 1975 - Icones Microfungorum a Matsushima Lectorum, Kobe, Japan, 1-209.

Mercado Sierra A, Heredia G, Mena Portales 1. 1995 - New species of dematiaceous hyphomycetes from Veracruz, Mexico. Mycotaxon 55, 491- 499.

Miller VM, Bonar L. 1941- A study of The Perisporiaceae, Capnodiaceae, and some other Sooty Molds from California. University of California Publications Botany 19 (12), 405-428.

Millot C. 1899 - Societe Des Sciences De Nancy. Bulletin de la Societe des sciences. Ancienne Societe Des Sciences Naturelles De Strasbourg. Available at: file:///C:/Users/HP/Downloads/ALS_1899_16_34.pdf (Accessed 13 January 2019)

Mohanan C. 1994a - Studies on diseases of bamboos and nursery management of Rhizoctonia web blight in Kerala. Ph.D. thesis. Cochin University of Science and Technology, Cochin.

Mohanan C. 1994b - Diseases of bamboos and rattans in Kerala. KFRI Research Report No. 98. Peechi, KFRI pp 120. Available at: http://www.docs.kfri.res.in/KFRI-RR/KFRI-RR098.pdf (Accessed 9 January 2019)

Müller E, Arx JA von. 1962 - Die Gattungen der didymosporen Pyrenomyceten. Beiträge zur Kryptogamenflora der Schweiz 11(2), 1-922.

Müller E, Sanwal BD - 1954. Uber die Gattungen Microcyclus Sacc., Coccoidella v. Hohn., Coccodothis Theiss. \& Sydow und Coccodothella Theiss. \& Sydow. Sydowia 8, 231-244.

Muthappa BN. 1969 - Morphology of a new Loculoascomycete on Bambusa arundinacea. Mycologia 61, 737-747.

Nelsen MP, Chavez N, Sackett-Hermann E, Thell A et al. 2011a - The cetrarioid core group revisited (Lecanorales: Parmeliaceae). Lichenologist 43, 537-551.

Nelsen MP, Lucking R, Grube M, Mbatchou JS et al. 2009 - Unravelling the phylogenetic relationships of lichenized fungi in Dothideomyceta. Studies in Mycology 64, 135-144.

Nelsen MP, Lucking R, Mbatchou JS, Andrew CJ et al. 2011b - New insights into relationships of lichen-forming Dothideomycetes. Fungal Diversity 51, 155-162.

Nelson S. 2008 - Sooty molds. Plant Disease 52, 1-6.

Nilsson RH, Hyde KD, Pawlowska J, Ryberg M et al. 2014 - Improving ITS sequence data for identification of plant pathogenic fungi. Fungal Diversity 67, 11-19

Niskanen T, Liimatainen K, Nuytinck J, Kirk P et al. 2018 - Identifying and naming the currently known diversity of the genus Hydnum with an emphasis on European and North American taxa. Mycologia 110, 890-918.

Nylander JAA, Ronquist F, Huelsenbeck JP, Nieves-Aldrey JL. 2004 - Bayesian phylogenetic analysis of combined data. Systematic Biology 53, 47-67.

Nylander W. 1873 - Observata lichenologica in Pyrenaeis orientalibus. Flora 56, 65-300.

Ossler J. 2010 - Seasonal and Salinity Effects on the Distribution of Higher Filamentous Marine Fungi at Rookery Bay, FL Master's thesis. Nova Southeastern University. Retrieved from NSUWorks, Oceanographic Center. (211) Available at:

Patouillard NT. 1889 - Le genre Ganoderma. Bulletin de la Société Mycologique de France 5, 6480.

Paulus BC. 2004 - The diversity and distribution of microfungi in leaf litter of an Australian wet tropics rainforest. PhD thesis James Cook University. Available at: https://researchonline.jcu.edu.au/1308/2/02whole.pdf (Accessed 9 April 2019). 
Pem D, Hongsanan S, Doilom M, Tibpromma S et al. 2019 - https://www.dothideomycetes.org: An online taxonomic resource for the classification, identification, and nomenclature of Dothideomycetes. Asian Journal of Mycology 2, 287-297.

Petrak F, Sydow H. 1925 - Kritisch-systematisch Originaluntersuchungen über Pyrenomyzeten, Sphaeropsideen und Melanconieen. Annales Mycologici 23, 209-294.

Petrak F. 1931- Mykologische Notizen. Annales Mycologici 29, 339-397.

Petrak F. 1954 - Beiträge zur Pilzflora Australiens. Sydowia 8, 192-220.

Petrak F. 1965 - Über die Gattung Cryptospora Tul. Sydowia 19, 268-278.

Petrak, F. (1961, publ. 1962) - Macrovalsaria Petr. n. gen., eine neue dothideale Pyrenomyzetengattung. Sydowia 15, 297-300.

Philips DH, Burdekin DA. 1992 - Decay fungi of broadleaved and coniferous trees. In: Diseases of Forest and Ornamental Trees. Palgrave MacMillan, London, pp 366-409.

Phillips AJL, Alves A, Abdollahzadeh J, Slippers B et al. 2013 - The Botryosphaeriaceae: genera and species known from culture. Studies in Mycology 76, 51-167.

Phillips AJL, Alves A, Pennycook SR, Johnston PR et al. 2008 - Resolving the phylogenetic and taxonomic status of dark-spored teleomorph genera in the Botryosphaeriaceae. Persoonia 21, 29-55.

Phillips DH, Burdekin D. 1982 - Diseases of Forest and Ornamental Trees. London: The Macmillan Press.

Phookamsak R, Boonmee S, Norphanphoun C, Wanasinghe DN et al. 2016 - Schizothyriaceae. Mycosphere 7, 154-189.

Phookamsak R, Hyde KD, Jeewon R, Bhat DJ et al. 2019 - Fungal diversity notes 929-1035: taxonomic and phylogenetic contributions on genera and species of fungi. Fungal Diversity 95, 1-273.

Phuphaibun A, Phiriyanphrun S, Sarinthu N. 1980 - Study on the causal agent of leaf blight disease of the sisal, Agave sisalana. Available at:

Pirozynski KA. 1977 - Notes on hyperparasitic Sphaeriales, Hypocreales and 'hypocreoid Dothideales'. Kew Bulletin 31, 595-610.

Pourmoghaddam MJ, Khodaparast SA, Hashemi SA, Amirmijani AR. 2015 - New records on the genus Diatrype and Byssothecium for Mycobiota of Iranian. 2nd Iranian Mycological Congress, 23-25 August 2015, University of Tehran, Karaj, Iran.

Pscheidt JW, Ocamb CM. 2019 - Pacific Northwest Plant Disease Management Handbook [online]. Corvallis, OR: Oregon State University. Available at: http://pnwhandbooks.org/plantdisease (accessed 7 April 2019).

Punithalingam E. 1969 - Studies on Sphaeropsidales in culture. I. Mycological Papers. 119, 1-24.

Rahim S, Dawar S, Zaki MJ. 2013 - Mycoflora associated with the seed samples of Cucurbita Pepo l. collected from Pakistan. Pakistan Journal of Botany 45, 2173-2179.

Raja HA, Violi HA, Shearer CA. 2010 - Freshwater ascomycetes: Alascospora evergladensis, a new genus and species from the Florida Everglades. Mycologia 102, 33-38.

Rambaut A, Drummond AJ. 2008 - Tracer. Version 1.3.2. Available at:

Rambaut A. 2012 - FigTree (version 1.4.0). Available at http://tree.bio.ed.ac.uk/ software/ figtree/

Rao PR. 1983 - Two new species of Bactrodesmium from India. Indian Journal of Mycology and Plant Pathology 13, 207-208.

Réblová M, Barr ME. 2000 - The genus Acanthostigma (Tubeufiaceae, Pleosporales). Sydowia 52, $258-285$.

Redhead SA, White GP. 1985 - Mycopappus, a new genus of leaf pathogens and two parasitic Anguillospora species. Canadian Journal of Botany 63, 1429-1435.

Reynolds DR, Gilbert GS. 2005 - Epifoliar fungi from Queensland, Australia. Australian Systematic Botany 18, 265-289.

Rossman AY, Allen WC, Braun U, Castlebury LA et al. 2016 - Overlooked competing asexual and sexually typified generic names of Ascomycota with recommendations for their use or protection. IMA Fungus 7, 285-304. 
Rossman AY. 1987 - The Tubeufiaceae and similar Loculoascomycetes. Mycological Papers 157, $1-71$.

Roumeguère. 1880 - Fungi Selecti Galliaei Exs.: no. 627

Ruszkiewicz-Michalska M. 2016 -The genus Asteromella (Fungi, Ascomycota) in Poland. Monographiae Botanicae 106, 1-164.

Saccardo PA. 1884 - Sylloge Fungorum: Sylloge Sphaeropsidearum et Melanconiearum. Sylloge Fungorum 3, 1-840.

Saccardo PA. 1889 - Discomyceteae et Phymatosphaeriaceae. Sylloge Fungorum. 8, 1-1143.

Samuels GJ, Rogers JD. 1986 - Botryohypoxylon gen. nov. and its anamorph, Iledon gen. nov. Mycotaxon 25, 629-637.

Schoch CL, Crous PW, Groenewald JZ, Boehm EWA et al. 2009 - A class-wide phylogenetic assessment of Dothideomycetes. Studies in Mycology 64, 1-15.

Seephueak P, Petcharat V, Phongpaichit S. 2010 - Fungi associated with leaf litter of para rubber (Hevea brasiliensis). Mycology 1, 213-227.

Seephueak P. 2012 - Fungi Associated with Degradation of Rubber Wood Logs and Leaf Litter. $\mathrm{Ph}$. D. Dissertation. Prince of Songkla University, Thailand.

Seifert KA, Morgan-Jones G, Gams W, Kendrick B. 2011 - The genera of Hyphomycetes. CBS Biodiversity Series 9, CBSKNAW Fungal Biodiversity Centre, Utrecht.

Semeniuk V. 1983 - Mangrove distribution in Northwestern Australia in relationship to regional and local freshwater 53, 11-31.

Shearer CA, Raja HA, Miller AN, Nelson P et al. 2019 - The molecular phylogeny of freshwater Dothideomycetes. Studies in Mycology 64, 145-153

Shenoy BD, Jeewon R, Wang H, Amandeep K et al. 2010 - Sequence data reveals phylogenetic affinities of fungal anamorphs Bahusutrabeeja, Diplococcium, Natarajania, Paliphora, Polyschema, Rattania and Spadicoides. Fungal Diversity 44, 161-169.

Shivas RG, Alcorn JL. 1996 - A checklist of plant pathogenic and other microfungi in the rainforests of the wet tropics of northern Queensland. Australasian Plant Pathology 25, 158173.

Shoemaker RA, Holm L, Eriksson OE. 2003 - Proposal to conserve the name Dothidea with a conserved type (Fungi: Dothideomycetes). Taxon 52, 623-625.

Shoemaker RA, Leclair PM. 1975 - Type studies of Massaria from the Wehmeyer Collection. Canadian Journal of Botany 53, 1568-1598.

Simmons EG. 1986 - Alternaria themes and variations (22-26). Mycotaxon 25(1), 287-308.

Sivanesan A. 1975 - Redisposition and description of some Amphisphaeria species and a note on Macrovalsaria. Transactions of the British Mycological Society 65, 395-402.

Sivanesan A. 1987 - Graminicolous species of Bipolaris, Curvularia, Drechslera, Exserohilum and their teleomorphs. Mycological Papers 158, 1-261.

Spegazzini C. 1924 - Algunos honguitos portoriqueños. Boletín de la Academia Nacional de Ciencias en Córdoba. 26, 335-368.

Spooner BM, Kirk PM. 1982 - Taxonomic notes on Excipularia and Scolicosporium. Transactions of the British Mycological Society 78, 247-257.

Stamatakis A, Hoover P, Rougemont J. 2008 - A rapid bootstrap algorithm for the RAxML web servers. Systematic Biology 57, 758-771.

Stevens FL. 1922 - The Helminthosporium foot rot of wheat, with observations on the morphology of Helminthosporium and on the occurrence of saltation in the genus. Illinois Natural History Survey bulletin 14, 76-185.

Stevens FL. 1923 - Parasitic fungi from British Guiana and Trinidad. Illinois Biology Monographs 8, 1-76.

Stevens FL. 1925 - Hawaiian fungi. Bulletin of the Bernice Bishop Museum. 19, 1-189.

Stevenson JA. 1926 - Foreign plant diseases: A manual of economic plant diseases which are new to or not widely distributed in the United States. Washington, DC: USDA, Office of the Secretary pp 171-172. 
Subramanian CV, Bhat DJ. 1977 - Bahusutrabeeja, a new genus of the Hyphomycetes. Canadian Journal of Botany 55 (16), 2202-2206.

Subramanian CV. 1971 - Hyphomycetes: an account of Indian species, except Cercosporae. Indian Council of Agricultural Research. Fungi series 9, 1-930.

Sun, JZ, Liu XZ, McKenzie EHC, Jeewon R et al. 2019 - Fungicolous fungi: terminology, diversity, distribution, evolution, and species checklist. Fungal Diversity 95, 1, 337-430.

Sutton BC. 1971 - Staninwardia gen. nov. (Melanconiales) on Eucalyptus. Transactions of the British Mycological Society 57 (3), 539-542.

Sutton BC. 1980 - The Coelomycetes. Fungi imperfecti with pycnidia, acervuli and stromata. Wallingford: CABI Publishing 1-696.

Sydow H. 1927- Fungi in itinere costaricense collecti. Annales Mycologici. 25 (1-2), 1-160.

Tamura K Stecher G Peterson D Filipski A Kumar S. 2013 - MEGA 6: molecular evolutionary genetics analysis version 6.0. Molecular Biology and Evolution 30, 2725-2729.

Tanaka K, Harada Y. 2005 - Bambusicolous fungi in Japan (6): Katumotoa, a new genus of phaeosphaeriaceous ascomycetes. Mycoscience 46, 313-318.

Taylor JE, Crous PW, Swart L. 2001 - Foliicolous and caulicolous fungi associated with Proteaceae cultivated in California. Mycotaxon 78, 75-103.

Tennakoon DS, Kuo CH, Jeewon R, Thambugala KM, Hyde KD. 2018 - Saprobic Lophiostomataceae (Dothideomycetes): Pseudolophiostoma mangiferae sp. nov. and Neovaginatispora fuckelii, a new record from Mangifera indica. Phytotaxa, 364(2), 157-171.

Thambugala KM, Ariyawansa HA, Li YM, Boonmee S et al. 2014 - Dothideales. Fungal Diversity 68, 105-158.

Thambugala KM, Chunfang Y, Camporesi E, Bahkali AH, Liu ZY, Hyde KD. 2015b Pseudodidymosphaeria gen. nov. in Massarinaceae. Phytotaxa 231, 271-282.

Thambugala KM, Hyde KD, Tanaka K, Tian Q et al. 2015 - Towards a natural classification and backbone tree for Lophiostomataceae, Floricolaceae, and Amorosiaceae fam.nov. Fungal Diversity 74, 199-266.

Thambugala KM, Wanasinghe DN, Phillips AJL, Camporesi E et al. 2018 - Mycosphere notes 150: Grass (Poaceae) inhabiting Dothideomycetes. Mycosphere 8, 697-796.

Theissen F, Sydow H. 1914 - Dothideazeen-Studien - II. Annales Mycologici 12, 268-281.

Theissen F, Sydow H. 1914 - Dothideazeen-Studien. Annales Mycologici 12, 176-194.

Thümen FV. 1880 - Mycotheca Universalis, Centurie 17 (1601-1700). Bulletin de la Société Impériale des Naturalistes de Moscou.

Tian Q, Chomnunti P, Bhat JD, Alias SA et al. 2014 - Towards a natural classification of Dothideomycetes 5: The genera Ascostratum, Chaetoscutula, Ceratocarpia, Cystocoleus, and Colensoniella (Dothideomycetes incertae sedis). Phytotaxa 176, 42-54.

Tian Q, Liu JK, Hyde KD, Wanasinghe DN et al. 2014 - Phylogenetic relationships and morphological reappraisal of Melanommataceae (Pleosporales). Fungal Diversity 74, 267324

Torrend C. 1914 - Fungi selecti exsiccati. 3 Centurie. Broteria Série Botanica 12, 58-69.

Tsuneda A, Davey M, Hambleton S, Currah RS. 2008 - Endosporium, a new endoconidial genus allied to the Myriangiales. Botany 86, 1020-1033.

Vainio EA. 1921 - Lichenes Siamenses. Annales Societatis Zoolog.-Bot. Fennicae 1, 33-55.

Van der Aa HA, Vanev S. 2002 - Revision of the species described in Phyllosticta. Utrecht: Centraalbureau voor Schimmelcultures. (Eds. Aptroot A, Summerbel RC, Verkley GJ.) CBS, Centralbureau voor Schimmelcultures, Utrecht an Institute of the Royal Netherlands Academy of Arts and Sciences. Pp 510.

Vargas GE. 1977 - White angular leafspot, a new disease of cucumber (Cucumis sativus L.), caused by Chuppia sp. [Costa Rica] [1977]. Available at: http://agris.fao.org/agrissearch/search.do?recordID=XL19770188929 (Accessed on 10 April 2019). 
Verkley GJM, da Silva M, Wicklow DT, Crous PW. 2004 - Paraconiothyrium, a new genus to accommodate the mycoparasite Coniothyrium minitans, anamorphs of Paraphaeosphaeria, and four new species. Studies in Mycology 50, 323-335.

Verkley GJM, Dukik K, Renfurm R, Goker M, Stielow JB. 2014 - Novel genera of coniothyriumlike fungi in Montagnulaceae (Ascomycota). Persoonia 32, 25-51.

Videira SIR, Groenewald JZ, Nakashima C, Braun U et al. 2017 - Mycosphaerellaceae - Chaos or clarity? Studies in Mycology 87, 257-421.

Vitale S, Aiello D, Guarnaccia V, Luongo L et al. 2018 - Liberomyces pistaciae sp. nov., the causal agent of pistachio cankers and decline in Italy. MycoKeys 40, $29-51$.

Von Arx JA, Muller E. 1975 - A reevaluation of the bitunicate Ascomycetes with keys to families and genera. Studies in Mycology 9, 1-159.

Wanasinghe DN, Jeewon R, Jones EBG, Tibpromma S and Hyde KD 2017 - Saprobic Dothideomycetes in Thailand: Muritestudina gen. et sp. nov. (Testudinaceae) a new terrestrial pleosporalean ascomycete, with hyaline and muriform ascospores. Studies in Fungi 2 (1), 219-234.

Wanasinghe DN, Phukhamsakda C, Hyde KD, Jeewon R et al. 2018 - Fungal diversity notes 709839: taxonomic and phylogenetic contributions to fungal taxa with an emphasis on fungi on Rosaceae. Fungal Diversity 89, 1-236.

Wijayawardene NN, Bhat DJ, Hyde KD, Camporesi E et al. 2014a - Camarosporium sensu stricto in Pleosporinae, Pleosporales with two new species. Phytotaxa 183, 16-26.

Wijayawardene NN, Crous PW, Kirk PM, Hawksworth DL et al. 2014b - Naming and outline of Dothideomycetes-2014 including proposals for the protection or suppression of generic names. Fungal Diversity 69, 1-5.

Wijayawardene NN, Hyde KD, Lumbsch HT, Liu JK et al. 2018 - Outline of Ascomycota: 2017. Fungal Diversity 88, 167-263.

Wijayawardene NN, Hyde KD, Rajeshkumar KC, Hawksworth DL et al. 2017 - Notes for genera: Ascomycota. Fungal Diversity 86, 1-594.

Winter G. 1883 - Repertorium Rabenhorstii Fungi europaei et extraeuropaei. Cent. 30. Hedwigia 22, $180-183$.

Wu HX, Hyde KD, Chen H. 2011 - Studies on Microthyriaceae: placement of Actinomyxa, Asteritea, Cirsosina, Polystomellina and Stegothyrium. Cryptogamie Mycologie 32, 3-12.

Wu HX, Schoch CL, Boonmee S, Bahkali AH et al. 2011 - A reappraisal of Microthyriaceae. Fungal Diversity 51, 189-248.

Wu WP, Mckenzie E. 2003 - Obeliospora minima sp. nov. and four other hyphomycetes with conidia bearing appendages. Fungal Diversity 12, 223-234.

Yan G, Riley IT. 2005 - Variation in colonisation of Lolium rigidum by isolates of Dilophospora alopecuri, an antagonist of the causal organisms of annual ryegrass toxicity. Australian Journal of Experimental Agriculture 45, 1157-1162.

Yang T, Groenewald JZ, Cheewangkoon R, Jami F et al. 2016 - Families, genera, and species of Botryosphaeriales. Fungal Biology 121, 322-346.

Zahlbruckner A. 1902 - Diagnosen neuer und genügend beschriebener kalifornischer Flechten. Beihefte zum Botanischen Centralblatt 13, 149 -163.

Zhang H, Hyde KD, McKenzie EHC, Bahkali AH, Zhou D. 2012 - Sequence data reveals phylogenetic affinities of Acrocalymma aquatica sp. nov., Aquasubmersa mircensis gen. et sp. nov. and Clohesyomyces aquaticus (Freshwater coelomycetes). Cryptogamie Mycologie 33, 333-346.

Zhang SN, Hyde KD, Jones EBG, Jeewon R, Cheewangkoon R, Liu JK. 2019 - Striatiguttulaceae, a new pleosporalean family to accommodate the genera Longicorpus gen. nov. and Striatiguttula gen. nov., from palms in mangrove ecosystem. MycoKeys, 49, 99-129.

Zhang Y, Crous PW, Schoch CL, Hyde KD. 2012 - Pleosporales. Fungal Diversity 53, 1-221. 
Zhang Y, Wang HK, Fournier J, Crous PW et al. 2009 - Towards a phylogenetic clarification of Lophiostoma/Massarina and morphologically similar genera in the Pleosporaceae. Fungal Diversity 38, 225-251. 